\title{
Using Nucleophilic Substitution Reactions to Understand How a Remote Alkyl or Alkoxy Substituent Influences the Conformation of Eight-Membered Ring Oxocarbenium Ions
}

\author{
Stephen Chamberland and K. A. Woerpel* \\ Department of Chemistry, University of California, \\ Irvine, California 92697-2025
}

Supporting Information

I. General Information

S-1

II. Synthesis of Eight-Membered Ring Lactol Acetates

A. Synthesis of Acetic acid 5-methyloxocan-2-yl ester (3a)

S-3

B. Synthesis of Acetic acid 5-(benzyloxy)oxocan-2-yl ester (3b)

S-5

C. Synthesis of Acetic acid 6-methyloxocan-2-yl ester (10a)

S-12

D. Synthesis of Acetic acid 6-(benzyloxy)oxocan-2-yl ester (10b)

S-16

E. Synthesis of Acetic acid 4-methyloxocan-2-yl ester (15a)

S-25

F. Synthesis of Acetic acid 4-(benzyloxy)oxocan-2-yl ester (15b)

$\mathrm{S}-29$

III. Nucleophilic Substitution Reactions

S-38

IV. Control Experiments
A. Kinetic Control Experiments
S-45
B. Initial Acetate Anomer Ratio Control Experiments
S-45
C. Insensitivity of Reaction Selectivities to Conditions
S-46

V. Stereochemical Proofs of Nucleophilic Substitution Products

A. Synthesis of 20 and X-ray Crystallographic Data S-47

B. Relevant ${ }^{1} \mathrm{H}$ NMR Coupling Constant Data $\quad$ S-59

C. DPFGSE-NOE and 2D-NOESY Data S-61

VI. Computational Studies to Predict Nucleophilic Substitution Product Ratios S-65

VII. Bibliography $\quad$ S-111

VIII. Analytical Data

GC Analysis of Isomer Ratios and ${ }^{1} \mathrm{H}$ NMR Spectra of Relevant Compounds $\quad$ S-113

\section{General Information}

${ }^{1} \mathrm{H}$ and ${ }^{13} \mathrm{C}$ NMR spectra were recorded at ambient temperature at $500 \mathrm{MHz}$ and 125

MHz, respectively, using Bruker DRX 500 spectrometers. All chemical shifts are reported in ppm relative to tetramethylsilane on the $\delta$ scale (or, where noted, to residual solvent peak), multiplicity $(\mathrm{br}=$ broad, $\mathrm{s}=$ singlet, $\mathrm{d}=$ doublet, $\mathrm{t}=$ triplet, $\mathrm{q}=$ quartet, quint $=$ quintet, and $\mathrm{m}=$ multiplet), coupling constants in $\mathrm{Hz}$, and integration. Infrared (IR) spectra were obtained using a MIDAC Prospect FT-IR spectrometer. High resolution mass spectra were acquired on a VG 
Analytical 7070E or Fisons Autospec spectrometer, and were obtained by peak matching. Elemental analyses were performed by Atlantic Microlab, Atlanta, GA. Analytical gas-liquid chromatography (GC) analyses were performed on a Hewlett Packard 5890 Level 4 Chromatograph, equipped with a split-mode injection system and a flame ionization detector. Fused silica capillary column $(30 \mathrm{~m} \times 0.32 \mathrm{~mm})$ wall-coated with DB-1 (J \& W Scientific) was used with helium as the carrier gas (16 psi column head pressure). Melting points are uncorrected. Liquid chromatography was performed using variable forced air flow (flash chromatography) of the indicated solvent system or solvent gradient on $60 \AA$ SiliTech or EM Reagents silica gel $\left(\mathrm{SiO}_{2}\right)(60 \AA$, 230-400 mesh). Where noted, silica gel was deactivated by first treating with $2 \% \mathrm{Et}_{3} \mathrm{~N}$ in hexanes. After standard wet packing of the column, excess $\mathrm{Et}_{3} \mathrm{~N}$ was removed by washing with four column lengths of 20:80 EtOAc/hexanes. Finally, the silica gel was washed with two column lengths of the initial eluent mixture. All reaction mixtures not containing aqueous reagents were carried out under an atmosphere of dry nitrogen using standard syringe/septa techniques. Glassware was oven-dried, and then both flame-dried and cooled to ambient temperature under a stream of dry nitrogen. Unless otherwise noted, all reagents were used as received from commercial suppliers. Tetrahydrofuran, diethyl ether, dichloromethane, and toluene were dried by filtration through alumina according to the procedure of Grubbs. ${ }^{1}$ Acetonitrile, benzene, diisopropylamine, triethylamine, and hexanes not used as chromatographic eluents were dried by distillation over $\mathrm{CaH}_{2}$. Commercially available $\mathrm{NaH}$ (60 $\%$ dispersion in oil) was washed with three portions of hexanes and dried under high vacuum immediately prior to use. Commercially available $\mathrm{KH}$ (30\% dispersion in mineral oil) was washed with $3 \times 100 \mathrm{~mL}$ of anhydrous hexanes using a Schlenk filter, dried under high vacuum, and stored in a nitrogen-atomsphere glove box. Celite was successively washed with one portion 
of distilled water, acetone, and hexanes before use. General method for theoretical experiments: A systematic conformational search $(6561$ cycles) considering all bonds in the ring using molecular mechanics (MMFF) was carried out, followed by geometry optimization of all unique structures at the semi-emperical (PM3) level of theory. Lastly, those conformers within 3 $\mathrm{kcal} / \mathrm{mol}$ of the lowest energy conformer were further optimized using density functional theory (B3LYP/6-31G*). All calculations were performed using Spartan '02.

\section{Synthesis of Acetates}

IIA. Synthesis of Acetic acid 5-methyloxocan-2-yl ester (3a)
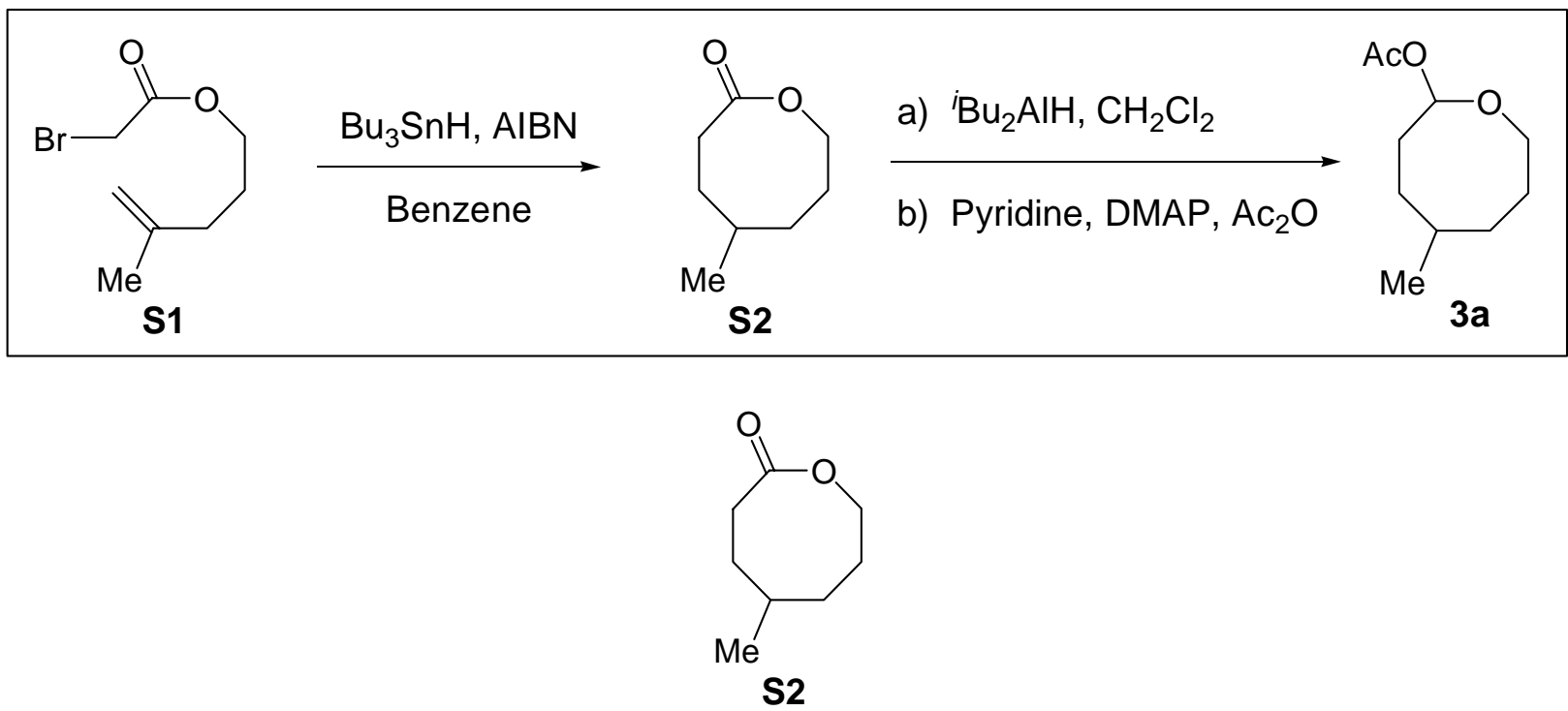

5-Methyloxocan-2-one (S2): ${ }^{2}$ To a refluxing solution of bromoacetate $\mathbf{S 1}^{3}(3.46 \mathrm{~g}, 15.7 \mathrm{mmol}$, $\left.\mathrm{R}_{f}=0.70,25: 75 \mathrm{EtOAc} / \mathrm{hexanes}\right)$ in $600 \mathrm{~mL}$ of benzene was added a solution of $n-\mathrm{Bu}_{3} \mathrm{SnH}(5.9$ $\mathrm{mL}, 21.9 \mathrm{mmol})$ and AIBN $(0.258 \mathrm{~g}, 1.57 \mathrm{mmol})$ in $40 \mathrm{~mL}$ of benzene by syringe pump over approximately $4 \mathrm{~h}$. The solution was heated at reflux for an additional $1 \mathrm{~h}$, and then was concentrated in vacuo. The resulting oil was purified first by flash column chromatography on deactivated silica gel (10:90 to 30:70 EtOAc/hexanes). Then, remaining tin residues were 
removed by washing a solution of the oil in $100 \mathrm{~mL}$ of anhydrous $\mathrm{CH}_{3} \mathrm{CN}$ with $2 \times 100 \mathrm{~mL}$ of anhydrous hexanes. Concentration of the $\mathrm{CH}_{3} \mathrm{CN}$ portion in vacuo afforded the pure product as a colorless oil $(0.968 \mathrm{~g}, 43 \%)$. The spectral data correlates with the previously reported data for S2: ${ }^{2} \mathrm{R}_{f}=0.30,25: 75 \mathrm{EtOAc} /$ hexanes; ${ }^{1} \mathrm{H} \mathrm{NMR}\left(\mathrm{CDCl}_{3}, 500 \mathrm{MHz}\right) \delta 4.33(\mathrm{~m}, 2 \mathrm{H}), 2.66(\mathrm{ddd}, J$ $=12.8,8.7,4.3,1 \mathrm{H}), 2.52(\mathrm{ddd}, J=12.8,8.7,4.5,1 \mathrm{H}), 1.94(\mathrm{~m}, 2 \mathrm{H}), 1.73(\mathrm{~m}, 1 \mathrm{H}), 1.57(\mathrm{~m}$, 2H), $1.47(\mathrm{~m} \mathrm{1H}), 1.35(\mathrm{~m}, 1 \mathrm{H}), 0.99(\mathrm{~d}, J=6.7,3 \mathrm{H}) ;{ }^{13} \mathrm{C} \mathrm{NMR}\left(\mathrm{CDCl}_{3}, 125 \mathrm{MHz}\right) \delta 176.5$, $68.2,36.1,32.4,32.3,30.4,30.1,24.7$.

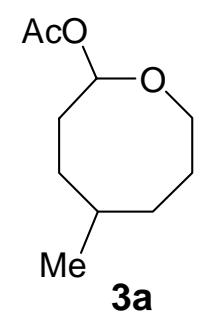

Acetic acid 5-methyloxocan-2-yl ester (3a): ${ }^{4}$ To a cooled $\left(-78{ }^{\circ} \mathrm{C}\right)$ solution of lactone S2 (0.450 g, $3.16 \mathrm{mmol})$ in $32 \mathrm{~mL}$ of $\mathrm{CH}_{2} \mathrm{Cl}_{2}$ was added ${ }^{i} \mathrm{Bu}_{2} \mathrm{AlH}$ (1.5 $\mathrm{M}$ in toluene, $4.2 \mathrm{~mL}, 6.32$ mmol) dropwise by syringe. After $45 \mathrm{~min}$, the reaction mixture was treated sequentially with pyridine $(0.77 \mathrm{~mL}, 9.48 \mathrm{mmol})$ dropwise by syringe, neat 4 - $(N, N$-dimethylamino)pyridine $(0.772$ $\mathrm{g}, 6.32 \mathrm{mmol})$, and $\mathrm{Ac}_{2} \mathrm{O}(1.80 \mathrm{~mL}, 19.0 \mathrm{mmol})$ dropwise by syringe. The mixture was stirred at $-78{ }^{\circ} \mathrm{C}$ for $14 \mathrm{~h}$, warmed to $0{ }^{\circ} \mathrm{C}$, and stirred for an additional $30 \mathrm{~min}$. Then, a mixture of saturated aqueous $\mathrm{NH}_{4} \mathrm{Cl}(10 \mathrm{~mL})$ and saturated aqueous sodium potassium tartrate $(10 \mathrm{~mL})$ was added. The resulting mixture was warmed to ambient temperature and was stirred vigorously for $1 \mathrm{~h}$ before $10 \mathrm{~mL}$ of brine was added. After the layers were separated, the aqueous portion was extracted with $5 \times 5 \mathrm{~mL}$ of $\mathrm{Et}_{2} \mathrm{O}$. The combined organic extracts were washed with ice-cold $1 \mathrm{M}$ $\mathrm{NaHSO}_{4}(2 \times 5 \mathrm{~mL})$, saturated aqueous $\mathrm{NaHCO}_{3}(3 \times 5 \mathrm{~mL})$, and brine $(1 \times 10 \mathrm{~mL})$, then they were dried over anhydrous $\mathrm{MgSO}_{4}$ and concentrated in vacuo. Purification by flash column 
chromatography on deactivated silica gel (10:90 to $30: 70 \mathrm{Et}_{2} \mathrm{O} /$ pentane) afforded the product (determined by $\mathrm{GC}$ to be a 61:39 ratio of diastereomers) as a volatile pale yellow oil (0.304 $\mathrm{g}$, 52\%): $\mathrm{R}_{f}=0.58,20: 80 \mathrm{EtOAc} /$ hexanes; GC $t_{\mathrm{R}}$ (major) $8.52 \mathrm{~min}, t_{\mathrm{R}}$ (minor) $8.81 \mathrm{~min}\left(50{ }^{\circ} \mathrm{C}\right.$ for 1 min, $10 \%$ min, to $\left.150{ }^{\circ} \mathrm{C}\right):{ }^{1} \mathrm{H} \mathrm{NMR}\left(\mathrm{CDCl}_{3}, 500 \mathrm{MHz}\right) \delta 5.90(\mathrm{dd}, J=10.5,2.7,0.6 \mathrm{H}), 5.77$ $(\mathrm{dd}, J=9.0,4.0,1 \mathrm{H}), 3.93-3.85(\mathrm{~m}, 2.6 \mathrm{H}), 3.74(\mathrm{dt}, J=12.6,4.2,0.6 \mathrm{H}), 2.07(\mathrm{~s}, 3 \mathrm{H}), 2.05(\mathrm{~s}$, $1.8 \mathrm{H}), 1.90-1.82(\mathrm{~m}, 1.6 \mathrm{H}), 1.81-1.70(\mathrm{~m}, 4.2 \mathrm{H}), 1.69-1.50(\mathrm{~m}, 5.2 \mathrm{H}), 1.49-1.29(\mathrm{~m}, 2.4 \mathrm{H})$, $1.23(\mathrm{~m}, 1 \mathrm{H}), 0.93(\mathrm{~d}, J=6.9,3 \mathrm{H}), 0.91(\mathrm{~d}, J=6.9,1.8 \mathrm{H}) ;{ }^{13} \mathrm{C} \mathrm{NMR}\left(\mathrm{CDCl}_{3}, 125 \mathrm{MHz}\right) \delta 170.4$ 170.2, 97.9, 97.0, 70.1, 65.9, 34.8, 33.0, 32.2, 31.9, 31.1, 30.5, 28.7, 28.5, 27.7, 24.8, 24.7, 21.3, 21.2; IR (neat) 2951, 2868, 1741, 1458, 1367, $1236 \mathrm{~cm}^{-1}$; HRMS (EI/GCMS) $\mathrm{m} / z$ calcd for $\mathrm{C}_{9} \mathrm{H}_{15} \mathrm{O}_{3}\left(\mathrm{M}-\mathrm{CH}_{3}\right)^{+}$171.1021, found 171.1018. Anal. Calcd for $\mathrm{C}_{10} \mathrm{H}_{18} \mathrm{O}_{3}$ : C, 64.49; $\mathrm{H}, 9.74$. Found: C, 63.99; H, 9.60. 
IIB. Synthesis of Acetic acid 5-(benzyloxy)oxocan-2-yl ester (3b)
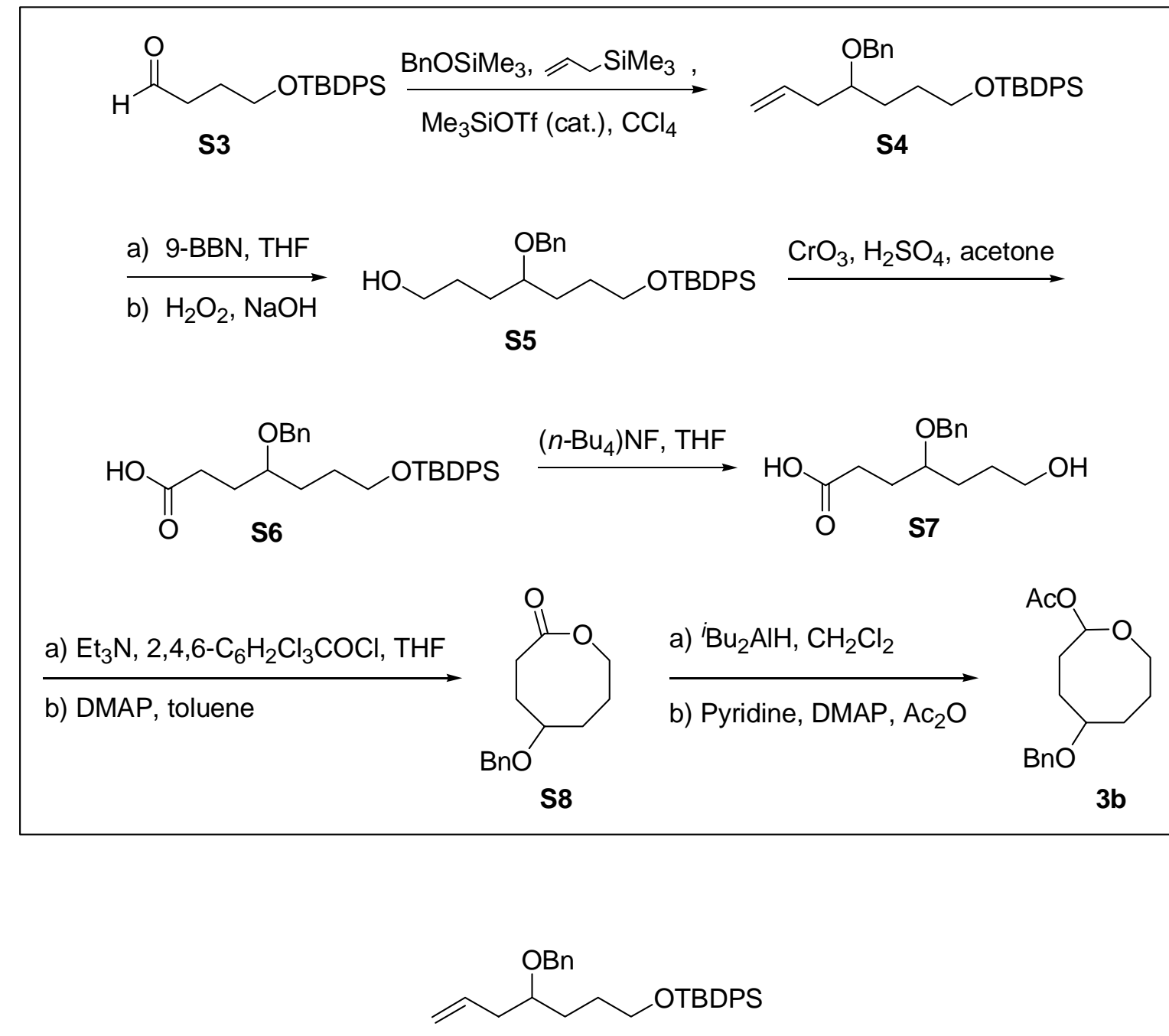

S4

4-Benzyloxy-1-[(tert-Butyldiphenylsilyl)oxy]hept-6-ene (S4): ${ }^{5}$ To a solution of aldehyde $\mathbf{S 3}^{6}$ (3.00 g, $9.19 \mathrm{mmol})$, allyltrimethylsilane (1.62 $\mathrm{mL}, 10.1 \mathrm{mmol}$, distilled prior to use), and benzyloxytrimethylsilane $(1.81 \mathrm{~mL}, 9.19 \mathrm{mmol}$, distilled prior to use) in $60 \mathrm{~mL}$ of anhydrous $\mathrm{CCl}_{4}$ at ambient temperature was added trimethylsilyl trifluoromethanesulfonate $(0.356 \mathrm{~mL}, 1.84$ mmol, distilled prior to use). The solution color evolved to dark brown over $30 \mathrm{~min}$. After such time, $50 \mathrm{~mL}$ of $5 \% \mathrm{NaHCO}_{3}$ was added dropwise to quench the Lewis acid. The layers were separated, and the aqueous portion was extracted with $3 \times 20 \mathrm{~mL}$ of $\mathrm{CH}_{2} \mathrm{Cl}_{2}$. The combined 
organic extracts were washed with $25 \mathrm{~mL}$ of brine, filtered through a cotton plug, and concentrated in vacuo. Purification by flash column chromatography on silica gel (60:40 benzene/hexanes) afforded a light brown oil $(2.45 \mathrm{~g}, 58 \%): \mathrm{R}_{f}=0.59,50: 50 \mathrm{CH}_{2} \mathrm{Cl}_{2} /$ hexanes; ${ }^{1} \mathrm{H}$ NMR (500 MHz, $\left.\mathrm{CDCl}_{3}\right) \delta 7.67(\mathrm{~m}, 4 \mathrm{H}), 7.43-7.26(\mathrm{~m}, 11 \mathrm{H}), 5.82(\mathrm{dtd}, J=14.4,10.0,6.8,1 \mathrm{H})$, $5.07(\mathrm{~m}, 2 \mathrm{H}), 4.54(\mathrm{~d}, J=11.6,1 \mathrm{H}), 4.46(\mathrm{~d}, J=11.6,1 \mathrm{H}), 3.66(\mathrm{t}, J=5.2,2 \mathrm{H}), 3.45$ (quint, $J=$ 5.9, 1H), $2.31(\mathrm{~m}, 2 \mathrm{H}), 1.71-1.59(\mathrm{~m}, 4 \mathrm{H}), 1.04(\mathrm{~s}, 9 \mathrm{H}) ;{ }^{13} \mathrm{C}$ NMR $\left(125 \mathrm{MHz}, \mathrm{CDCl}_{3}\right) \delta 138.9$, 135.6, 135.0, 134.1, 129.5, 128.3, 127.7, 127.6, 127.4, 116.9, 78.3, 70.8, 63.9, 38.3, 29.9, 28.3, 26.9, 19.2; IR (neat) 3070, 2931, 2857, 1428, 1111, $823 \mathrm{~cm}^{-1}$; HRMS (Cl/isobutane) $\mathrm{m} / \mathrm{z}$ calcd for $\mathrm{C}_{30} \mathrm{H}_{39} \mathrm{O}_{2} \mathrm{Si}(\mathrm{M}+\mathrm{H})^{+}$459.2719, found 459.2717. Anal. Calcd for $\mathrm{C}_{30} \mathrm{H}_{38} \mathrm{O}_{2} \mathrm{Si}$ : C, 78.55; $\mathrm{H}$, 8.35. Found: $\mathrm{C}, 78.36 ; \mathrm{H}, 8.52$.

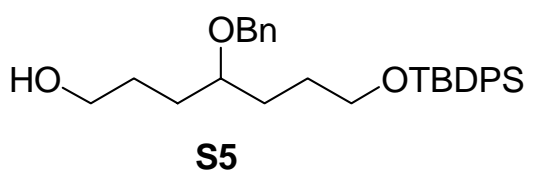

\section{4-Benzyloxy-7-[(tert-Butyldiphenylsilyl)oxy)]heptan-1-ol (S5): ${ }^{7}$}

9-Borabicyclo[3.3.1]nonane (9-BBN-H) ${ }^{8}(0.638 \mathrm{~g}, 5.23 \mathrm{mmol})$ was dissolved in $10 \mathrm{~mL}$ of THF. A solution of alkene $\mathbf{S 4}(1.20 \mathrm{~g}, 2.62 \mathrm{mmol})$ in $20 \mathrm{~mL}$ of THF was introduced by cannula, and the mixture was stirred at ambient temperature for $4 \mathrm{~h}$. The solution was cooled to $0{ }^{\circ} \mathrm{C}$, and 1.0 M NaOH (11.9 mL), $\mathrm{MeOH}(20 \mathrm{~mL})$, and $30 \%$ aqueous $\mathrm{H}_{2} \mathrm{O}_{2}(4.7 \mathrm{~mL})$ were successively added dropwise by pipet (caution: very exothermic). The mixture was warmed to ambient temperature and stirred for $12 \mathrm{~h}$. Then, the mixture was partitioned between $30 \mathrm{~mL}$ of brine and $30 \mathrm{~mL}$ of $\mathrm{Et}_{2} \mathrm{O}$, and the layers were separated. The aqueous portion was extracted with $3 \times 20$ $\mathrm{mL}$ of $\mathrm{Et}_{2} \mathrm{O}$. The combined organic extracts were dried over anhydrous $\mathrm{MgSO}_{4}$, filtered, and concentrated in vacuo. The resulting material was purified by flash column chromatography on 
silica gel (95:5 $\left.\mathrm{CH}_{2} \mathrm{Cl}_{2} / \mathrm{MeOH}\right)$ to afford the product as a colorless oil $(1.17 \mathrm{~g}, 94 \%): \mathrm{R}_{f}=0.40$, 30:70 EtOAc/hexanes; ${ }^{1} \mathrm{H}$ NMR (500 MHz, $\left.\mathrm{CDCl}_{3}\right) \delta$ 7.69-7.68 (m, 4H), 7.46-7.27 (m, 11H), $4.50(\mathrm{~d}, J=11.5,1 \mathrm{H}), 4.45(\mathrm{~d}, J=11.5,1 \mathrm{H}), 3.69(\mathrm{t}, J=5.7,2 \mathrm{H}), 3.63(\mathrm{t}, J=5.4,2 \mathrm{H}), 3.46$ (quint, $J=5.2,1 \mathrm{H}), 1.71-1.60(\mathrm{~m}, 8 \mathrm{H}), 1.07(\mathrm{~s}, 9 \mathrm{H}) ;{ }^{13} \mathrm{C} \mathrm{NMR}\left(125 \mathrm{MHz}, \mathrm{CDCl}_{3}\right) \delta 138.6$, $135.6,134.8,134.0,129.5,128.3,127.8,127.6,78.5,70.7,63.9,62.9,30.2,29.6,28.6,28.2$, 26.9, 19.2; IR (neat) 3417 (br), 2931, 2852, 1428, 1112, 909, $\mathrm{cm}^{-1} ; \mathrm{HRMS}\left(\mathrm{CI} / \mathrm{NH}_{3}\right) \mathrm{m} / z$ calcd for $\mathrm{C}_{30} \mathrm{H}_{41} \mathrm{O}_{3} \mathrm{Si}(\mathrm{M}+\mathrm{H})^{+}$477.2825, found 477.2819. Anal. Calcd for $\mathrm{C}_{30} \mathrm{H}_{40} \mathrm{O}_{3} \mathrm{Si}$ : C, 75.58; $\mathrm{H}$, 8.46. Found: C, $75.53 ; \mathrm{H}, 8.52$.<smiles>O=C(O)CCC(Br)CCCO[Mg]</smiles>

4-Benzyloxy-7-[(tert-Butyldiphenylsilyl)oxy $]$ heptanoic acid (S6): ${ }^{9}$ To a cooled $\left(0{ }^{\circ} \mathrm{C}\right)$ solution of alcohol S5 (6.047 g, $12.69 \mathrm{mmol})$ in $12.7 \mathrm{~mL}$ of acetone was added Jones reagent ${ }^{10}(11.5 \mathrm{~mL}$, $30.5 \mathrm{mmol}$ ) dropwise using a glass syringe. The suspension was stirred for $1 \mathrm{~h}$ at $0{ }^{\circ} \mathrm{C}$, and then isopropyl alcohol $(10 \mathrm{~mL})$ was added with stirring to reduce the excess Jones reagent. The resulting solution was warmed to ambient temperature then filtered through an $\mathrm{Et}_{2} \mathrm{O}$-moistened pad of washed Celite to remove the turquoise residue. This residue was washed with one $20 \mathrm{~mL}$ portion of $\mathrm{Et}_{2} \mathrm{O}$. The filtrate was then concentrated in vacuo. The resulting oil was partitioned between $10 \mathrm{~mL}$ of brine and $50 \mathrm{~mL}$ of $\mathrm{CH}_{2} \mathrm{Cl}_{2}$, and the aqueous portion was extracted with $3 \times$ $10 \mathrm{~mL}$ of $\mathrm{CH}_{2} \mathrm{Cl}_{2}$. The combined organic extracts were dried over anhydrous $\mathrm{Na}_{2} \mathrm{SO}_{4}$ and concentrated in vacuo. Purification by flash column chromatography on silica gel (95:5:1 $\left.\mathrm{CH}_{2} \mathrm{Cl}_{2} / \mathrm{MeOH} / \mathrm{AcOH}\right)$ afforded the product as a pale yellow oil $(6.20 \mathrm{~g}, 99 \%): \mathrm{R}_{f}=0.40,95: 5$ $\mathrm{CH}_{2} \mathrm{Cl}_{2} / \mathrm{MeOH} ;{ }^{1} \mathrm{H} \mathrm{NMR}\left(500 \mathrm{MHz}, \mathrm{CDCl}_{3}\right) \delta 11.00($ br s, $1 \mathrm{H}), 7.66(\mathrm{dd}, J=7.9,1.4,4 \mathrm{H})$, 
$7.41-7.26(\mathrm{~m}, 11 \mathrm{H}), 4.50(\mathrm{~d}, J=11.5,1 \mathrm{H}), 4.44(\mathrm{~d}, J=11.5,1 \mathrm{H}), 3.67(\mathrm{t}, J=5.9,2 \mathrm{H}), 3.46(\mathrm{~m}$, 1H), $2.44(\mathrm{~m}, 2 \mathrm{H}), 1.84(\mathrm{~m}, 2 \mathrm{H}), 1.62(\mathrm{~m}, 4 \mathrm{H}), 1.05(\mathrm{~s}, 9 \mathrm{H}) ;{ }^{13} \mathrm{C} \mathrm{NMR}\left(125 \mathrm{MHz}, \mathrm{CDCl}_{3}\right) \delta$ 179.5, 138.5, 135.6, 134.0, 129.6, 128.4, 127.8, 127.62, 127.55, 77.5, 70.8, 63.8, 30.0, 29.7, 28.6, 28.1, 26.9, 19.2; IR (thin film) 3400-2400 (br), 2932, 1707, 1428, 1283, $1112 \mathrm{~cm}^{-1}$; HRMS (FAB-MS) $m / z$ calcd for $\mathrm{C}_{30} \mathrm{H}_{39} \mathrm{O}_{4} \mathrm{Si}(\mathrm{M}+\mathrm{H})^{+}$491.2617, found 491.2627. Anal. Calcd for $\mathrm{C}_{30} \mathrm{H}_{38} \mathrm{O}_{4} \mathrm{Si}:$ C, $73.43 ; \mathrm{H}, 7.81$. Found: $\mathrm{C}, 73.57 ; \mathrm{H}, 8.00$.

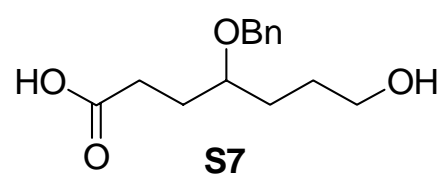

4-Benzyloxy-7-hydroxyheptanoic acid (S7): ${ }^{11}$ To a cooled $\left(0{ }^{\circ} \mathrm{C}\right)$ solution of silyl ether $\mathbf{S 6}$ $(0.547 \mathrm{~g}, 1.12 \mathrm{mmol})$ in $11.2 \mathrm{~mL}$ of THF was added $n-\mathrm{Bu}_{4} \mathrm{NF}(4.48 \mathrm{~mL}$ of a $1.0 \mathrm{M}$ solution in THF). The reaction mixture was stirred for $5 \mathrm{~h}$, and then was warmed to ambient temperature. The solution was partitioned between $20 \mathrm{~mL}$ of EtOAc and $100 \mathrm{~mL}$ of $1.0 \mathrm{M} \mathrm{HCl}$, the layers were separated, and the aqueous portion was extracted with $2 \times 20 \mathrm{~mL}$ of EtOAc. The combined organic extracts were dried over anhydrous $\mathrm{MgSO}_{4}$, filtered, and concentrated in vacuo. Purification by flash column chromatography on silica gel (25:75:1 Acetone/ $\left.\mathrm{CH}_{2} \mathrm{Cl}_{2} / \mathrm{HOAc}\right)$ afforded the product as a colorless syrup $(0.239 \mathrm{~g}, \quad 85 \%): \quad \mathrm{R}_{f}=0.33, \quad 75: 25: 1$ $\mathrm{CH}_{2} \mathrm{Cl}_{2} /$ Acetone/AcOH; ${ }^{1} \mathrm{H}$ NMR $\left(500 \mathrm{MHz}, \mathrm{CDCl}_{3}\right) \delta 10.69$ (br s, $\left.1 \mathrm{H}\right), 7.30(\mathrm{~m}, 5 \mathrm{H}), 4.53$ (d, $J$ $=11.5,1 \mathrm{H}), 4.50(\mathrm{~d}, J=11.5,1 \mathrm{H}), 3.64(\mathrm{~m}, 2 \mathrm{H}), 3.51$ (quint, $J=4.8,1 \mathrm{H}), 2.44(\mathrm{t}, J=7.5,2 \mathrm{H})$, $1.90(\mathrm{~m}, 2 \mathrm{H}) 1.64(\mathrm{~m}, 4 \mathrm{H})\left[-\mathrm{OH}\right.$ peak does not appear]; ${ }^{13} \mathrm{C} \mathrm{NMR}\left(125 \mathrm{MHz}, \mathrm{CDCl}_{3}\right) \delta$ 178.6, 183.2, 128.4, 127.9, 127.7, 77.6, 71.0, 62.8, 29.9, 29.8, 28.4, 28.2; IR (thin film) 3504 (br), 2949, 1713, 1422, 1363, $1223 \mathrm{~cm}^{-1}$; HRMS $\left(\mathrm{CI} / \mathrm{NH}_{3}\right) \mathrm{m} / \mathrm{z}$ calcd for $\mathrm{C}_{14} \mathrm{H}_{21} \mathrm{O}_{4}(\mathrm{M}+\mathrm{H})^{+}$253.1440, found 253.1440; Anal. Calcd for $\mathrm{C}_{14} \mathrm{H}_{20} \mathrm{O}_{4}$ : C, 66.65; H, 7.99. Found: C, 66.12; H, 8.19. 


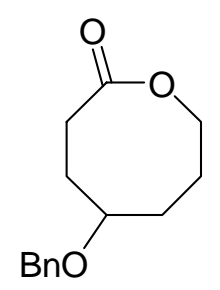

S8<smiles>O=C(O)CCCOC(=O)CCC(O)CCCCC(O)Cc1ccccc1</smiles>

S9

\section{5-(Benzyloxy)oxocan-2-one (S8), $\left(5 R^{*}, 13 S^{*}\right)$-5,13-bis(Benzyloxy)-1,9-dioxacyclohexadecan-}

\section{2,10-dione (S9a), and (5R*,13R*)-5,13-bis(Benzyloxy)-1,9-}

dioxacyclohexadecan-2,10-dione (S9b): ${ }^{12}$ To a solution of carboxylic acid $\mathbf{S 7}(0.100 \mathrm{~g}, 0.397$ $\mathrm{mmol}$ ) in $4.0 \mathrm{~mL}$ of THF were added powdered $4 \AA$ molecular sieves (approximately $0.02 \mathrm{~g}$ ), and $\mathrm{Et}_{3} \mathrm{~N}(0.083 \mathrm{~mL}, 0.596 \mathrm{mmol})$. The mixture was stirred for $15 \mathrm{~min}$. Then, a solution of 2,4,6trichlorobenzoyl chloride $(0.0682 \mathrm{~mL}, 0.437 \mathrm{mmol})$ in $2 \mathrm{~mL}$ of THF was introduced by cannula, and the mixture was stirred for $3 \mathrm{~h}$. The solution was diluted with $20 \mathrm{~mL}$ of toluene, and then was added over a period of $4 \mathrm{~h}$ by syringe pump to a refluxing solution of $4-(N, N-$ dimethylamino)pyridine $(0.728 \mathrm{~g}, 5.96 \mathrm{mmol})$ in $20 \mathrm{~mL}$ of toluene. After $12 \mathrm{~h}$, the reaction mixture was cooled to ambient temperature, and $20 \mathrm{~mL}$ of pH 7.00 buffer was added. The layers were separated, and the aqueous portion was extracted with $3 \times 10 \mathrm{~mL}$ of EtOAc. The combined organic extracts were washed with $20 \mathrm{~mL}$ of brine, dried over anhydrous $\mathrm{Na}_{2} \mathrm{SO}_{4}$, filtered, and concentrated in vacuo. The resulting oil was purified by flash column chromatography on deactivated silica gel (10:90:1 to 50:50:1 EtOAc/hexanes/Et $\left.{ }_{3} \mathrm{~N}\right)$ to afford lactone $\mathbf{S 8}$ as a pale yellow oil (0.057 $\mathrm{g}, 62 \%)$, and dimers S9a and S9b as an inseparable 1:1 mixture of diastereomers, also as a pale yellow oil (0.016 g, 17\%):

(S8): $\mathrm{R}_{f}=0.30,30: 70$ EtOAc/hexanes; ${ }^{1} \mathrm{H}$ NMR (500 MHz, $\left.\mathrm{C}_{6} \mathrm{D}_{6}\right) \delta 7.23-7.09(\mathrm{~m}, 5 \mathrm{H})$, $4.12(\mathrm{~s}, 2 \mathrm{H}), 3.97(\mathrm{ddd}, J=12.5,9.3,3.8,1 \mathrm{H}), 3.61(\mathrm{dt}, J=12.5,4.9,1 \mathrm{H}), 3.21(\mathrm{tt}, J=7.9,1.8$, 1H), $2.26(\mathrm{ddd}, J=13.1,9.2,4.3,1 \mathrm{H}), 2.00(\mathrm{ddd}, J=13.1,9.2,4.3,1 \mathrm{H}), 1.83-1.70(\mathrm{~m}, 2 \mathrm{H})$, 
1.54-1.27 (m, 4H); ${ }^{13} \mathrm{C}$ NMR $\left(125 \mathrm{MHz}, \mathrm{CDCl}_{3}\right) \delta 176.1,138.3,128.3,127.5,127.3,76.4,70.6$ 68.2, 33.1, 29.3, 27.4, 27.3; IR (neat) 2935, 2865, 1728, 1453, 1362, $1101 \mathrm{~cm}^{-1} ; \mathrm{HRMS}\left(\mathrm{CI} / \mathrm{NH}_{3}\right)$ $m / z$ calcd for $\mathrm{C}_{14} \mathrm{H}_{19} \mathrm{O}_{3}(\mathrm{M}+\mathrm{H})^{+}$235.1334, found 235.1339. Anal. Calcd for $\mathrm{C}_{14} \mathrm{H}_{18} \mathrm{O}_{3}$ : C, 71.77; H, 7.74. Found: C, 71.36; H, 7.91.

(S9a and S9b): $\mathrm{R}_{f}=0.60,30: 70$ EtOAc/hexanes; ${ }^{1} \mathrm{H}$ NMR $\left(500 \mathrm{MHz}, \mathrm{C}_{6} \mathrm{D}_{6}\right) \delta 7.31(\mathrm{~m}$, $8 \mathrm{H}), 7.19(\mathrm{t}, J=7.4,8 \mathrm{H}), 7.10(\mathrm{~m}, 4 \mathrm{H}), 4.46(\mathrm{~d}, J=11.8,2 \mathrm{H}), 4.42(\mathrm{~d}, J=11.8,2 \mathrm{H}), 4.23(\mathrm{~d}, J=$ $11.8,2 \mathrm{H}), 4.18(\mathrm{~d}, J=11.8,2 \mathrm{H}), 4.13(\mathrm{ddd}, J=11.0,8.7,2.3,2 \mathrm{H}), 4.04(\mathrm{ddd}, J=10.8,6.7,3.3$, 2H), $3.92(\mathrm{ddd}, J=11.0,8.1,2.9,2 \mathrm{H}), 3.75(\mathrm{ddd}, J=10.8,5.9,3.3,2 \mathrm{H}), 3.29(\mathrm{~m}, 2 \mathrm{H}), 3.23(\mathrm{~m}$, 2H), $2.23(\mathrm{~m}, 4 \mathrm{H}), 2.16-2.09(\mathrm{~m}, 4 \mathrm{H}), 1.99(\mathrm{dt}, J=9.8,4.2,1 \mathrm{H}), 1.97(\mathrm{dt}, J=9.8,4.2,1 \mathrm{H}), 1.79$ $(\mathrm{m}, 4 \mathrm{H}), 1.70-1.59(\mathrm{~m}, 6 \mathrm{H}), 1.54-1.33(\mathrm{~m}, 12 \mathrm{H}) ;{ }^{13} \mathrm{C} \mathrm{NMR}\left(125 \mathrm{MHz}, \mathrm{CDCl}_{3}\right) \delta 173.54$, 173.50, 138.6, 128.34, 128.31, 127.9, 127.8, 127.6, 127.5, 77.4, 76.7, 71.1, 71.0, 64.1, 63.8, 30.1, 29.9, 29.8, 29.7, 28.41, 28.36, 24.9, 24.8; IR (thin film, $\mathrm{CHCl}_{3}$ ): 3452, 3019, 1725, 1659, 1216, $909 \mathrm{~cm}^{-1}$; HRMS $\left(\mathrm{CI} / \mathrm{NH}_{3}\right) \mathrm{m} / z$ calcd for $\mathrm{C}_{28} \mathrm{H}_{37} \mathrm{O}_{6}(\mathrm{M}+\mathrm{H})^{+}$469.2590, found 469.2586. Anal. Calcd for $\mathrm{C}_{28} \mathrm{H}_{36} \mathrm{O}_{6}$ : C, 71.77; H, 7.74. Found: C, 71.63; H, 7.91.

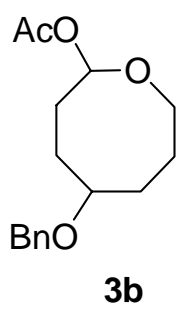

Acetic acid 5-(benzyloxy)oxocan-2-yl ester (3b): ${ }^{4}$ To a cooled $\left(-78{ }^{\circ} \mathrm{C}\right)$ solution of lactone $\mathbf{S 8}$ (0.539 g, $2.30 \mathrm{mmol})$ in $23 \mathrm{~mL}$ of $\mathrm{CH}_{2} \mathrm{Cl}_{2}$ was added ${ }^{i} \mathrm{Bu}_{2} \mathrm{AlH}(1.5 \mathrm{M}$ in toluene, $3.1 \mathrm{~mL}, 4.6$ mmol) dropwise by syringe. After $45 \mathrm{~min}$, the reaction mixture was treated sequentially with pyridine $(0.56 \mathrm{~mL}, 6.9 \mathrm{mmol})$ dropwise by syringe, neat 4 -( $N, N$-dimethylamino)pyridine $(0.562$ $\mathrm{g}, 4.60 \mathrm{mmol})$, and $\mathrm{Ac}_{2} \mathrm{O}(1.30 \mathrm{~mL}, 13.8 \mathrm{mmol})$ dropwise by syringe. The mixture was stirred at 
$-78{ }^{\circ} \mathrm{C}$ for $14 \mathrm{~h}$, warmed to $0{ }^{\circ} \mathrm{C}$, and stirred for an additional $30 \mathrm{~min}$. After $30 \mathrm{~min}$, a mixture of saturated aqueous $\mathrm{NH}_{4} \mathrm{Cl}(10 \mathrm{~mL})$ and saturated aqueous sodium potassium tartrate $(10 \mathrm{~mL})$ was added. The resulting mixture was then warmed to ambient temperature and stirred vigorously for $1 \mathrm{~h}$ before $10 \mathrm{~mL}$ of brine was added. After the layers were separated, the aqueous portion was extracted with $5 \times 5 \mathrm{~mL}^{\text {of }} \mathrm{Et}_{2} \mathrm{O}$. The combined organic extracts were washed with ice-cold $1.0 \mathrm{M} \mathrm{NaHSO}_{4}(2 \times 5 \mathrm{~mL})$, saturated $\mathrm{NaHCO}_{3}(3 \times 5 \mathrm{~mL})$, and brine $(10$ $\mathrm{mL}$ ), and then were dried over anhydrous $\mathrm{MgSO}_{4}$, filtered, and concentrated in vacuo. Partial purification was achieved on a Merck $20 \times 20 \mathrm{~cm}$ silica gel $60 \mathrm{~F}_{254}$ preparative layer plate eluted with 30:70:2 EtOAc/hexanes/Et $3 \mathrm{~N}$ to give a yellow oil as an approximate 70:30 mixture of diastereomers $(0.371 \mathrm{~g}, 58 \%): \quad \mathrm{R}_{f}=0.57,30: 70$ EtOAc/hexanes; GC $t_{\mathrm{R}}$ (major) $12.72 \mathrm{~min}$, $t_{\mathrm{R}}$ (minor) $13.05 \min \left(100{ }^{\circ} \mathrm{C}\right.$ for $1 \mathrm{~min}, 10 \% \mathrm{~min}$, to $\left.250{ }^{\circ} \mathrm{C}\right):{ }^{1} \mathrm{H}$ NMR $\left(500 \mathrm{MHz}, \mathrm{CDCl}_{3}\right) \delta$ 7.34-7.26 (m, 8H), $5.87(\mathrm{dd}, J=10.8,3.2,0.4 \mathrm{H}), 5.71(\mathrm{dd}, J=9.2,2.9,1 \mathrm{H}), 4.50(\mathrm{dd}, J=12.0$, 12.0, 4.8H), $3.96(\mathrm{ddd}, J=12.0,4.9,4.5,1 \mathrm{H}), 3.86(\mathrm{ddd}, J=13.0,10.4,3.3,0.4 \mathrm{H}), 3.78(\mathrm{~m}$, 2H), 3.67 (ddd, $J=13.0,8.3,4.1,0.4 \mathrm{H}), 2.054$ (s, 3H), 2.045 (s, 1.2H), $2.02-1.59(\mathrm{~m}, 12 \mathrm{H}) ;{ }^{13} \mathrm{C}$ NMR $\left(125 \mathrm{MHz}, \mathrm{CDCl}_{3}\right) \delta 170.4,170.0,128.3,127.48,127.46,127.41,97.5,96.1,78.9,77.8$, $70.5,70.4,64.5,64.1,32.9,31.7,31.4,29.5,29.1,27.5,26.6,26.2,21.2$; IR (neat) 2931, 1740, 1455, 1367, 1243, $1017 \mathrm{~cm}^{-1}$; HRMS $\left(\mathrm{CI} / \mathrm{NH}_{3}\right) \mathrm{m} / z$ calcd for $\mathrm{C}_{14} \mathrm{H}_{19} \mathrm{O}_{2}\left(\mathrm{M}-\mathrm{CH}_{3} \mathrm{CO}_{2}\right)^{+}$ 235.1334, found 235.1338. Anal. Calcd for $\mathrm{C}_{16} \mathrm{H}_{22} \mathrm{O}_{4}$ : C, 69.03; H, 7.97. Found: C, 69.57; H, 8.11. 
IIC. Synthesis of Acetic acid 6-methyloxocan-2-yl ester (10a)
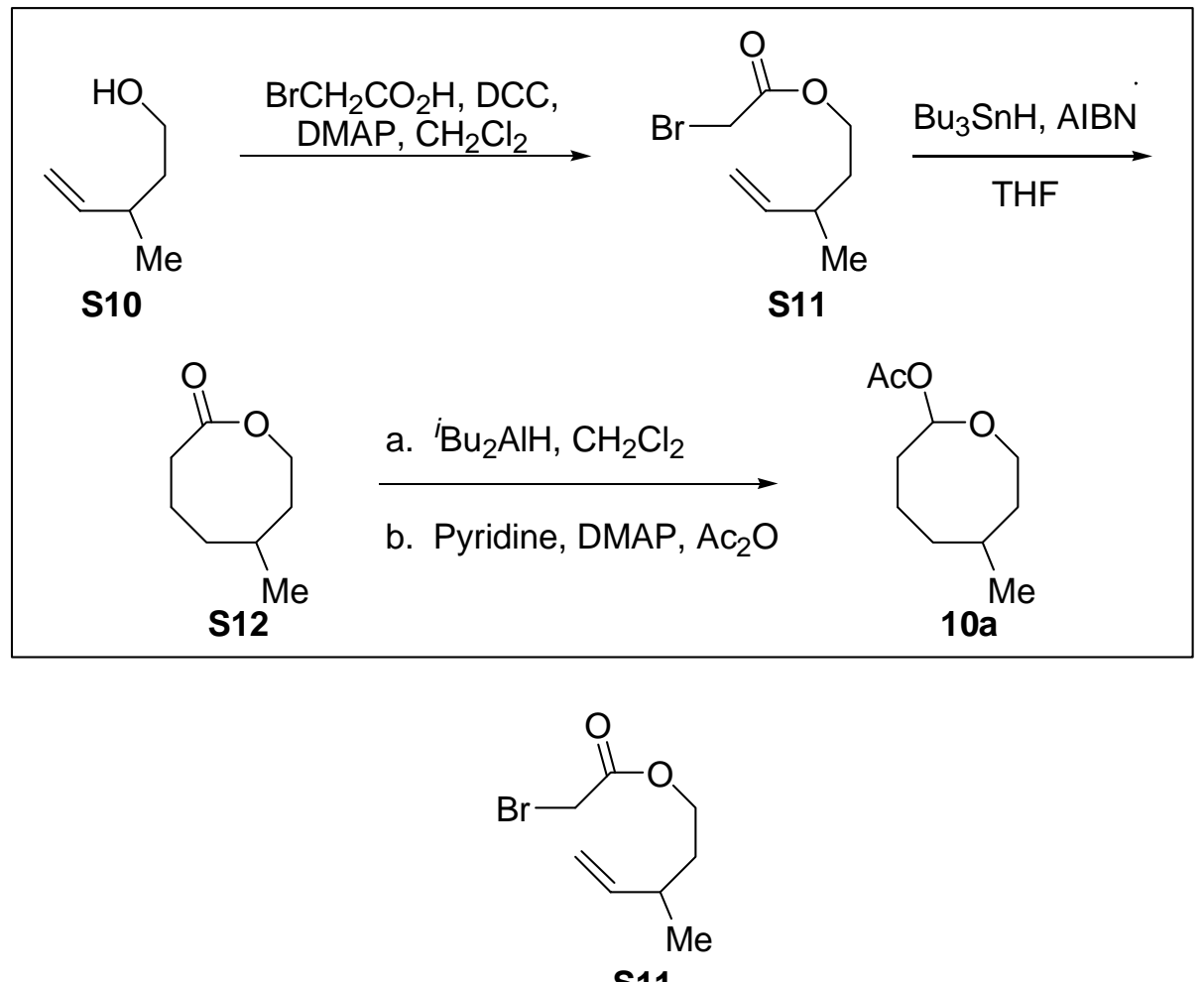

Bromoacetic acid 3-methylpent-4-enyl ester $(\mathbf{S 1 1}):^{2}$ To a cooled $\left(0{ }^{\circ} \mathrm{C}\right)$ solution of $N, N$ dicyclohexylcarbodiimide (12.71 g, $59.46 \mathrm{mmol})$ in $450 \mathrm{~mL}$ of anhydrous $\mathrm{CH}_{2} \mathrm{Cl}_{2}$ was added bromoacetic acid $(4.9 \mathrm{~mL}, 67 \mathrm{mmol})$, and the mixture was stirred at that temperature for $30 \mathrm{~min}$. Then, a solution of 3-methyl-4-penten-1-ol $(\mathbf{S 1 0})^{13}\left(3.972 \mathrm{~g}, 39.64 \mathrm{mmol}, \mathrm{R}_{f}=0.43,20: 80\right.$ EtOAc/hexanes) in $\mathrm{CH}_{2} \mathrm{Cl}_{2}(250 \mathrm{~mL})$ was added by cannula. After 10 minutes, neat 4-(N,Ndimethylamino)pyridine ( $1.84 \mathrm{~g}, 15.06 \mathrm{mmol})$ was added, and the mixture was stirred for $90 \mathrm{~min}$ with warming to ambient temperature. Then, the reaction mixture was vacuum-filtered through a pad of silica gel, and concentrated in vacuo. Purification by flash column chromatography on silica gel (10:90 to 20:80 EtOAc/hexanes) afforded the product as a light brown liquid (7.662 $\mathrm{g}$, 87\%): $\mathrm{R}_{f}=0.70$ in 25:75 EtOAc/hexanes; ${ }^{1} \mathrm{H}$ NMR $\left(500 \mathrm{MHz}, \mathrm{CDCl}_{3}\right) \delta 5.67$ (ddd, $J=17.7$, $10.2,8.0,1 \mathrm{H}), 4.99(\mathrm{~m}, 2 \mathrm{H}), 4.21(\mathrm{dt}, J=11.2,6.5,1 \mathrm{H}), 4.16(\mathrm{dt}, J=11.2,6.8,1 \mathrm{H}), 3.82(\mathrm{~s}$, 
2H), 2.29 (septet, $J=7.7,1 \mathrm{H}), 1.66(\mathrm{~m}, 2 \mathrm{H}), 1.04(\mathrm{~d}, J=6.8,3 \mathrm{H}) ;{ }^{13} \mathrm{C} \mathrm{NMR}\left(\mathrm{CDCl}_{3}, 125 \mathrm{MHz}\right)$ $\delta 167.0,142.9,113.6,64.4,34.7,34.5,25.7,20.1$; IR (neat) 2964, 2869, 1739, 1282, 1166, 1111 $\mathrm{cm}^{-1}$; HRMS (ES+) $m / z$ calcd for $\mathrm{C}_{4} \mathrm{H}_{6} \mathrm{O}_{2} \mathrm{Br}\left(\mathrm{M}-\mathrm{C}_{4} \mathrm{H}_{7}\right)^{+}$164.9551, found 164.9555. Anal. Calcd for $\mathrm{C}_{8} \mathrm{H}_{13} \mathrm{O}_{2} \mathrm{Br}:$ C, 43.46; H, 5.93. Found: C, 43.72; H, 6.17.

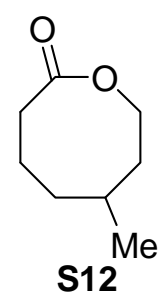

6-Methyloxocan-2-one (S12): ${ }^{2}$ To a solution of bromoacetate S11 $(2.21 \mathrm{~g}, 10.0 \mathrm{mmol})$ in 600 $\mathrm{mL}$ of anhydrous benzene at reflux was added a solution of $n-\mathrm{Bu}_{3} \mathrm{SnH}(3.76 \mathrm{~mL}, 14.0 \mathrm{mmol})$ and AIBN $(0.164 \mathrm{~g}, 1.00 \mathrm{mmol})$ in $40 \mathrm{~mL}$ of benzene by syringe pump over approximately $4 \mathrm{~h}$. The solution was heated at reflux for one additional hour, then was cooled to ambient temperature and concentrated in vacuo. The resulting oil was purified first by flash column chromatography (0:100 to 20:80 EtOAc/hexanes) on deactivated silica gel. Then, the remaining tin compounds were removed by washing a solution of the oil in $100 \mathrm{~mL}$ of anhydrous $\mathrm{CH}_{3} \mathrm{CN}$ with $2 \times 100 \mathrm{~mL}$ of anhydrous hexanes. Concentration of the $\mathrm{CH}_{3} \mathrm{CN}$ layer in vacuo afforded the pure lactone $(0.839 \mathrm{~g}, 59 \%)$ as a volatile colorless oil: $\mathrm{R}_{f}=0.40,20: 80 \mathrm{EtOAc} /$ hexanes; ${ }^{1} \mathrm{H}$ NMR $(500 \mathrm{MHz}$, $\left.\mathrm{CDCl}_{3}\right) \delta 4.38(\mathrm{ddd}, J=12.7,9.2,3.2,1 \mathrm{H}), 4.33(\mathrm{ddd}, J=12.7,5.1,4.9,1 \mathrm{H}), 2.66(\mathrm{ddd}, J=$ $12.8,8.7,4.3,1 \mathrm{H}), 2.52(\mathrm{ddd}, J=12.8,9.6,4.5,1 \mathrm{H}), 2.01(\mathrm{~m}, 1 \mathrm{H}), 1.93(\mathrm{ddt}, J=13.6,9.2,4.9$, $1 \mathrm{H}), 1.73(\mathrm{tdt}, \mathrm{J}=13.6,9.6,4.3,1 \mathrm{H}), 1.61(\mathrm{ddd}, J=14.9,4.5,4.1,1 \mathrm{H}), 1.57(\mathrm{~m}, 1 \mathrm{H}), 1.41(\mathrm{~m}$, 2H), $0.99(\mathrm{~d}, J=6.8,3 \mathrm{H}) ;{ }^{13} \mathrm{C} \mathrm{NMR}\left(125 \mathrm{MHz}, \mathrm{CDCl}_{3}\right) \delta 176.4,67.6,39.5,34.2,30.9,30.5$, 26.9, 24.4; IR (neat) 2956, 2872, 1732, 1454, 1288, $1108 \mathrm{~cm}^{-1}$; HRMS (ES+) $\mathrm{m} / \mathrm{z}$ calcd for 
$\mathrm{C}_{8} \mathrm{H}_{14} \mathrm{O}_{2}\left(\mathrm{M}^{+}\right)$142.0994, found 142.0999. Anal. Calcd for $\mathrm{C}_{8} \mathrm{H}_{14} \mathrm{O}_{2}$ : C, 67.57; H, 9.92. Found: C, 66.95; H, 9.84 .

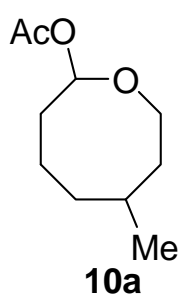

Acetic acid 6-methyloxocan-2-yl ester (10a): ${ }^{4}$ To a cooled $\left(-78{ }^{\circ} \mathrm{C}\right)$ solution of lactone $\mathbf{S 1 2}$ (0.42 g, $2.95 \mathrm{mmol})$ in $30 \mathrm{~mL}$ of $\mathrm{CH}_{2} \mathrm{Cl}_{2}$ was added ${ }^{i} \mathrm{Bu}_{2} \mathrm{AlH}(1.5 \mathrm{M}$ in toluene, $4.0 \mathrm{~mL}, 6.0$ mmol) dropwise by syringe. After $45 \mathrm{~min}$, the reaction mixture was treated sequentially with pyridine $(0.72 \mathrm{~mL}, 5.9 \mathrm{mmol})$ dropwise by syringe, neat 4 -( $N, N$-dimethylamino)pyridine $(0.721$ $\mathrm{g}, 5.90 \mathrm{mmol})$, and $\mathrm{Ac}_{2} \mathrm{O}(1.70 \mathrm{~mL}, 17.7 \mathrm{mmol})$ dropwise by syringe. The mixture was stirred at $-78{ }^{\circ} \mathrm{C}$ for $14 \mathrm{~h}$, warmed to $0{ }^{\circ} \mathrm{C}$, and stirred for an additional $30 \mathrm{~min}$. After 30 minutes, saturated aqueous $\mathrm{NH}_{4} \mathrm{Cl}(10 \mathrm{~mL})$ and saturated aqueous sodium potassium tartrate $(10 \mathrm{~mL})$ were added. The resulting mixture was then warmed to ambient temperature, and it was stirred vigorously for $1 \mathrm{~h}$ before $10 \mathrm{~mL}$ of brine was added. After the layers were separated, the

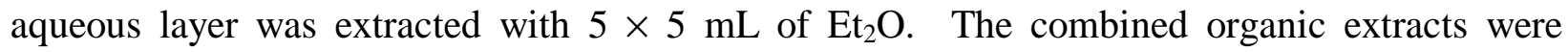
washed with ice-cold $1.0 \mathrm{M} \mathrm{NaHSO}_{4}(2 \times 5 \mathrm{~mL})$, saturated aqueous $\mathrm{NaHCO}_{3}(3 \times 5 \mathrm{~mL})$, brine $(1 \times 10 \mathrm{~mL})$, and then they were dried over anhydrous $\mathrm{MgSO}_{4}$, and concentrated in vacuo. Purification by flash column chromatography on deactivated silica gel (10:90 to 30:70 $\mathrm{Et}_{2} \mathrm{O} /$ pentane) afforded the product as a volatile pale yellow oil and as an inseparable 55:45 mixture of diastereomers $(0.136 \mathrm{~g}, 25 \%): \mathrm{R}_{f}=0.57,20: 80$ EtOAc/hexanes; GC $t_{\mathrm{R}}$ (major) 8.73 $\min , t_{\mathrm{R}}$ (minor) $8.57 \mathrm{~min}\left(50^{\circ} \mathrm{C}\right.$ for $1 \mathrm{~min}, 10 \% \mathrm{~min}$, to $\left.150{ }^{\circ} \mathrm{C}\right):{ }^{1} \mathrm{H} \mathrm{NMR}\left(500 \mathrm{MHz}, \mathrm{CDCl}_{3}\right) \delta$ $5.84(\mathrm{dd}, J=10.3,2.0,1 \mathrm{H}), 5.78(\mathrm{dd}, J=8.5,4.7,0.8,0.8 \mathrm{H}), 4.01(\mathrm{ddd}, J=12.4,8.7,3.5,0.8 \mathrm{H})$, 
$3.90(\mathrm{ddd}, J=12.4,3.9,2.6,1 \mathrm{H}), 3.85(\mathrm{ddd}, J=12.4,6.3,4.4,1 \mathrm{H}), 3.83(\mathrm{td}, J=12.4,2.4,0.8 \mathrm{H})$, $2.053(\mathrm{~s}, 3 \mathrm{H}), 2.052(\mathrm{~s}, 2.4 \mathrm{H}), 1.89(\mathrm{~m}, 3.6 \mathrm{H}), 1.70(\mathrm{~m}, 4.6 \mathrm{H}), 1.58(\mathrm{~m}, 4.4 \mathrm{H}), 1.40(\mathrm{~m}, 3.6 \mathrm{H})$ $0.97(\mathrm{~d}, J=6.6,2.4 \mathrm{H}), 0.92(\mathrm{~d}, J=6.7,3 \mathrm{H}) ;{ }^{13} \mathrm{C} \mathrm{NMR}\left(125 \mathrm{MHz}, \mathrm{CDCl}_{3}\right) \delta 170.4,170.2,98.4$, $96.5,67.7,65.8,36.5,35.4,35.3,33.8,33.0,32.9,32.0,30.8,30.2,24.2,23.0,22.8,21.2,20.4$ IR (neat) 2953, 2868, 1744, 1457, 1368, $1237 \mathrm{~cm}^{-1}$; Anal. Calcd for $\mathrm{C}_{10} \mathrm{H}_{18} \mathrm{O}_{3}: \mathrm{C}, 64.49 ; \mathrm{H}$, 9.74. Found: C, 64.36; H, 9.74 .

IID. Synthesis of Acetic acid 6-(benzyloxy)oxocan-2-yl ester (10b)

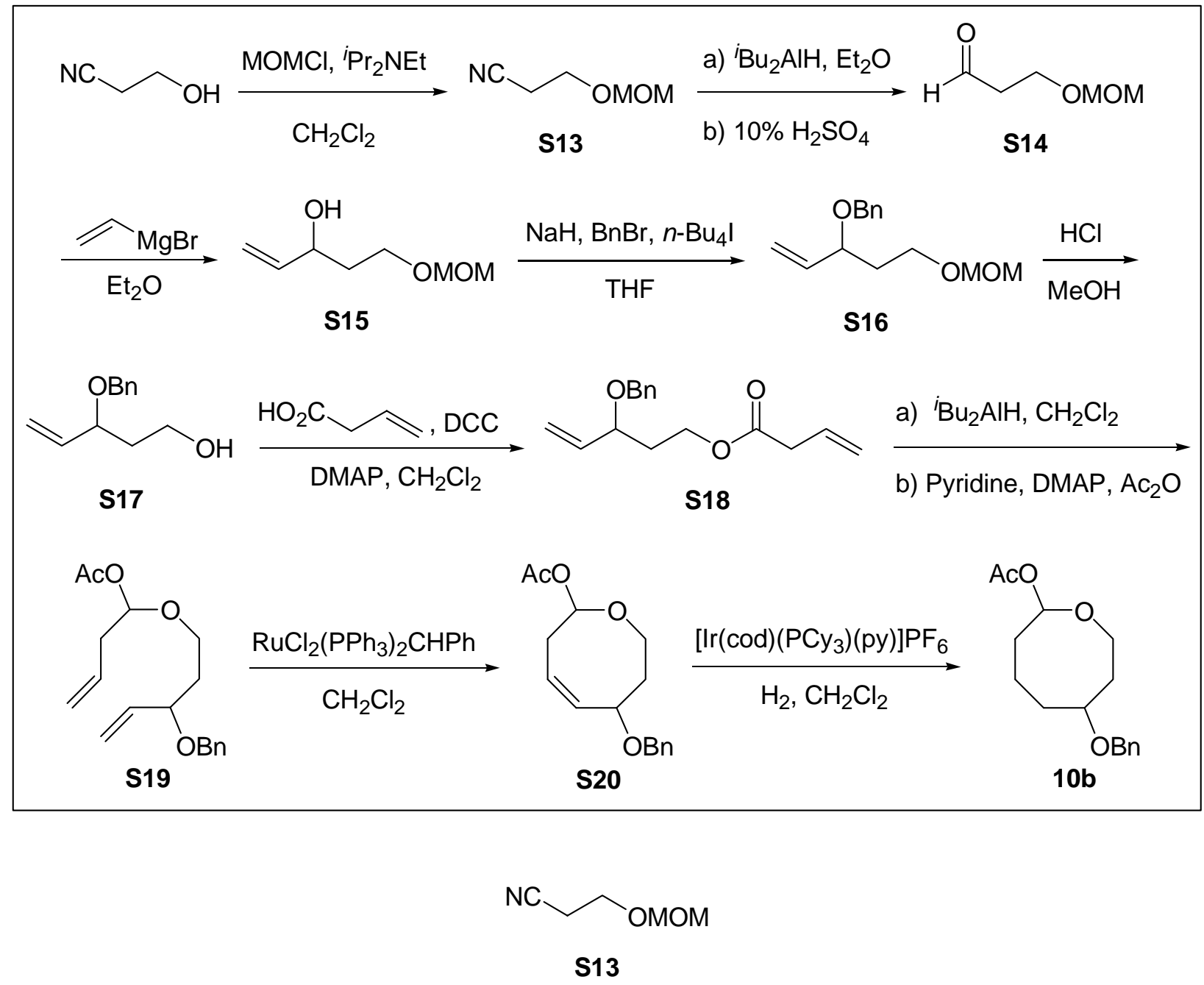


3-(Methoxymethoxy)propionitrile $\quad(\mathbf{S 1 3}):^{14} \quad$ To a cooled $\quad\left(\begin{array}{lllll} & \left.{ }^{\circ} \mathrm{C}\right) & \text { solution of } & 3-\end{array}\right.$ hydroxypropionitrile $(9.5 \mathrm{~mL}, 0.14 \mathrm{~mol})$ and $N, N$-diisopropylethylamine $(61 \mathrm{~mL}, 0.35 \mathrm{~mol})$ in 80 $\mathrm{mL}$ of $\mathrm{CH}_{2} \mathrm{Cl}_{2}$ was added chloromethyl methyl ether $(12.8 \mathrm{~mL}, 0.168 \mathrm{~mol})$ dropwise by syringe. The reaction mixture was warmed to ambient temperature and stirred for $12 \mathrm{~h}$. The mixture was diluted with $\mathrm{CH}_{2} \mathrm{Cl}_{2}(300 \mathrm{~mL})$, then was washed with $5 \% \mathrm{HCl}(3 \times 100 \mathrm{~mL})$, dried over $\mathrm{MgSO}_{4}$, filtered, and concentrated in vacuo to afford a brown liquid. Distillation of this material under high vacuum (bp $75-80{ }^{\circ} \mathrm{C}$; lit. ${ }^{14} 75-79^{\circ} \mathrm{C}, 0.1 \mathrm{~mm}$ ) gave a colorless liquid $(12.22 \mathrm{~g}, 73 \%$ ). The spectral data correlates with the previously reported data for $\mathbf{S 1 3 :}{ }^{14}{ }^{1} \mathrm{H}$ NMR $\left(500 \mathrm{MHz}, \mathrm{CDCl}_{3}\right)$ $\delta 4.67(\mathrm{~s}, 2 \mathrm{H}), 3.76(\mathrm{t}, J=6.2,2 \mathrm{H}), 3.41(\mathrm{~s}, 3 \mathrm{H}), 2.65(\mathrm{t}, J=6.2,2 \mathrm{H}) ;{ }^{13} \mathrm{C}$ NMR $(125 \mathrm{MHz}$, $\left.\mathrm{CDCl}_{3}\right) \delta 117.7,96.5,62.3,55.6,19.1$.

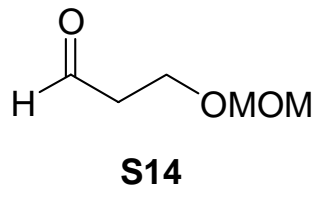

3-(Methoxymethoxy)propionaldehyde $(\mathbf{S 1 4}):^{15}$ To a cooled $\left(-78{ }^{\circ} \mathrm{C}\right)$ solution of 3 (methoxymethoxy)propionitrile $(\mathbf{S 1 3})(8.32 \mathrm{~g}, 70.0 \mathrm{mmol})$ in $350 \mathrm{~mL}$ of anhydrous $\mathrm{Et}_{2} \mathrm{O}$ was added a solution of ${ }^{i} \mathrm{Bu}_{2} \mathrm{AlH}(1.5 \mathrm{M}$ in toluene, $65.3 \mathrm{~mL}, 98.0 \mathrm{mmol})$ dropwise by syringe. Then, the solution was warmed to an internal temperature of $-15^{\circ} \mathrm{C}$, and was quenched by adding 120 $\mathrm{mL}$ of $10 \% \mathrm{H}_{2} \mathrm{SO}_{4}$. The mixture was vigorously stirred for $10 \mathrm{~min}$ with warming to ambient temperature, then $280 \mathrm{~mL}$ of a saturated aqueous solution of $\mathrm{NaHCO}_{3}$ was slowly added, followed by an additional 10 min of stirring. The layers were separated, and the aqueous layer was extracted with $\mathrm{Et}_{2} \mathrm{O}(8 \times 100 \mathrm{~mL})$. The combined organic extracts were washed with brine (200 mL), dried over anhydrous $\mathrm{MgSO}_{4}$, filtered, and gently concentrated in vacuo at $0{ }^{\circ} \mathrm{C}$. Purification by flash column chromatography on silica gel (20:80 to 60:40 $\mathrm{Et}_{2} \mathrm{O} /$ pentane) 
afforded the product as a volatile colorless liquid $(3.14 \mathrm{~g}, 37 \%)$. The spectral data correlates with the previously reported data for S14: ${ }^{14} \mathrm{H}$ NMR $\left(500 \mathrm{MHz}, \mathrm{CDCl}_{3}\right) \delta 9.80(\mathrm{t}, J=1.8,1 \mathrm{H})$, $4.63(\mathrm{~s}, 2 \mathrm{H}), 3.89(\mathrm{t}, J=6.0,2 \mathrm{H}), 3.36(\mathrm{~s}, 3 \mathrm{H}), 2.70(\mathrm{dt}, J=6.0,1.8,2 \mathrm{H}) ;{ }^{13} \mathrm{C} \mathrm{NMR}(125 \mathrm{MHz}$, $\left.\mathrm{CDCl}_{3}\right) \delta 200.8,96.4,61.2,55.1,43.7$.

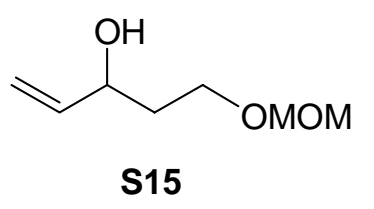

5-(Methoxymethoxy)pent-1-en-3-ol (S15): ${ }^{14}$ To a cooled $\left(-78 \quad{ }^{\circ} \mathrm{C}\right)$ solution of 3 (methoxymethoxy)propionaldehyde (S14) $(3.14 \mathrm{~g}, 25.8 \mathrm{mmol})$ in $20 \mathrm{~mL}$ of anhydrous tetrahydrofuran was added vinylmagnesium bromide $(1.0 \mathrm{M}$ in tetrahydrofuran, $34 \mathrm{~mL}, 34$ mmol) dropwise by syringe, and the solution was stirred for 30 min with warming to ambient temperature. Then, $40 \mathrm{~mL}$ of saturated aqueous $\mathrm{NH}_{4} \mathrm{Cl}$ were added, and the solution was concentrated in vacuo. The resulting material was acidified with $25 \mathrm{~mL}$ of $5 \% \mathrm{HCl}$, and it was extracted with $\mathrm{Et}_{2} \mathrm{O}(3 \times 40 \mathrm{~mL})$. The combined organic extracts were washed with $100 \mathrm{~mL}$ of brine, dried over $\mathrm{MgSO}_{4}$, filtered, and gently concentrated in vacuo at $0{ }^{\circ} \mathrm{C}$. Purification by flash column chromatography on silica gel (40:60 to 50:50 $\mathrm{Et}_{2} \mathrm{O} /$ hexanes) afforded the product as a volatile pale yellow oil $(2.53 \mathrm{~g}, 67 \%)$. The spectral data correlates with the previously reported data for S15: ${ }^{14} \mathrm{R}_{f}=0.21,40: 60 \mathrm{Et}_{2} \mathrm{O} /$ hexanes; ${ }^{1} \mathrm{H}$ NMR $\left(500 \mathrm{MHz}, \mathrm{CDCl}_{3}\right) \delta 5.90$ (ddd, $J=$ $17.0,10.5,5.7,1 \mathrm{H}), 5.29(\mathrm{dt}, J=17.0,1.3,1 \mathrm{H}), 5.13(\mathrm{dt}, J=10.5,1.2,1 \mathrm{H}), 4.63(\mathrm{~s}, 2 \mathrm{H}), 4.33$ (m, 1H), $3.75(\mathrm{ddd}, J=9.8,6.9,5.0,1 \mathrm{H}), 3.68(\mathrm{ddd}, J=9.8,6.9,5.0,1 \mathrm{H}), 3.38(\mathrm{~s}, 3 \mathrm{H}), 2.57(\mathrm{~d}$, $J=4.0,1 \mathrm{H}), 1.84(\mathrm{~m}, 2 \mathrm{H}) ;{ }^{13} \mathrm{C} \mathrm{NMR}\left(125 \mathrm{MHz}, \mathrm{CDCl}_{3}\right) \delta 140.5,114.5,96.5,71.5,65.4,55.3$, 36.3 . 


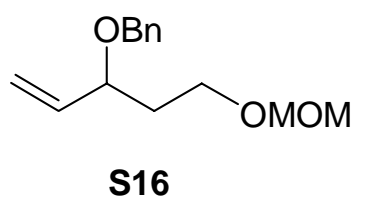

3-Benzyloxy-5-(methoxymethoxy)-1-pentene (S16): ${ }^{14}$ To a cooled $\left(0{ }^{\circ} \mathrm{C}\right)$ suspension of $\mathrm{NaH}$ $(0.397 \mathrm{~g}, 16.6 \mathrm{mmol})$ in $15 \mathrm{~mL}$ of anhydrous tetrahydrofuran was added a solution of 5 (methoxymethoxy)-1-penten-3-ol (S15) (1.86 g, $12.7 \mathrm{mmol})$ in $15 \mathrm{~mL}$ of anhydrous tetrahydrofuran dropwise by syringe. After $1 \mathrm{~h}$, benzyl bromide $(1.7 \mathrm{~mL}, 14 \mathrm{mmol}$, distilled from $\left.\mathrm{CaH}_{2}\right)$ and $n-\mathrm{Bu}_{4} \mathrm{NI}(0.625 \mathrm{~g}, 1.94 \mathrm{mmol})$ were added, and the solution was stirred for $12 \mathrm{~h}$ with warming to ambient temperature. Then, the mixture was filtered, and the filtrate was concentrated, taken up in $10 \mathrm{~mL}$ of $\mathrm{Et}_{2} \mathrm{O}$, and acidified with $5 \mathrm{~mL}$ of $1.0 \mathrm{M} \mathrm{HCl}$. The layers were separated, and the aqueous portion was extracted with $3 \times 1 \mathrm{~mL}^{\text {of }} \mathrm{Et}_{2} \mathrm{O}$. The combined organic extracts were washed with $5 \mathrm{~mL}$ of $\mathrm{H}_{2} \mathrm{O}$, dried over anhydrous $\mathrm{MgSO}_{4}$, filtered, and concentrated in vacuo. Purification by flash column chromatography on silica gel (15:85 to 50:50 $\mathrm{Et}_{2} \mathrm{O} /$ hexanes) gave the product as a pale yellow oil $(1.718 \mathrm{~g}, 57 \%)$ and $0.198 \mathrm{~g}$ of recovered allylic alcohol S15. The spectral data correlates with the previously reported data for S16: ${ }^{14} \mathrm{R}_{f}=0.35,15: 85 \mathrm{Et}_{2} \mathrm{O} /$ hexanes; ${ }^{1} \mathrm{H}$ NMR $\left(500 \mathrm{MHz}, \mathrm{CDCl}_{3}\right) \delta 7.29(\mathrm{~m}, 5 \mathrm{H}), 5.76$ (ddd, $J$ $=17.1,10.5,5.5,1 \mathrm{H}), 5.26(\mathrm{~d}, J=17.1,1 \mathrm{H}), 5.25(\mathrm{~d}, J=10.5,1 \mathrm{H}), 4.60(\mathrm{~d}, J=11.7,1 \mathrm{H}), 4.58$ (m, 2H), $4.35(\mathrm{~d}, J=11.7,1 \mathrm{H}), 3.94(\mathrm{dt}, J=7.7,5.5,1 \mathrm{H}), 3.63(\mathrm{~m}, 2 \mathrm{H}), 3.33(\mathrm{~s}, 3 \mathrm{H}), 1.94(\mathrm{~m}$, 1H), $1.80(\mathrm{~m}, 1 \mathrm{H}) ;{ }^{13} \mathrm{C} \mathrm{NMR}\left(125 \mathrm{MHz}, \mathrm{CDCl}_{3}\right) \delta 138.63,138.61,128.3,127.8,127.5,117.4$ $96.5,77.6,70.2,64.2,55.1,35.8$.

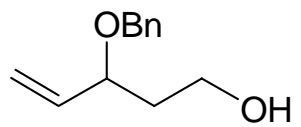


3-(Benzyloxy)pent-4-en-1-ol (S17): ${ }^{14}$ To a solution of 3-benzyloxy-5-(methoxymethoxy)-1pentene (S16) (1.72 g, $7.26 \mathrm{mmol})$ in $40 \mathrm{~mL}$ of $\mathrm{MeOH}$ was added 4 drops of concentrated $\mathrm{HCl}$. The mixture was heated at reflux for $2.5 \mathrm{~h}$, and then was cooled to ambient temperature, concentrated, and taken up in $20 \mathrm{~mL}^{\circ} \mathrm{Et}_{2} \mathrm{O}$. The ethereal solution was washed with $5 \mathrm{~mL}$ of saturated aqueous $\mathrm{NaHCO}_{3}, 5 \mathrm{~mL}$ of $\mathrm{H}_{2} \mathrm{O}$, then was dried over $\mathrm{MgSO}_{4}$, filtered, and concentrated in vacuo to afford the product as a brown liquid and of sufficient purity to carry on to the next step without further manipulation $(1.274 \mathrm{~g}, 91 \%)$. The spectral data correlates with the previously reported data for $\mathbf{S 1 7}:{ }^{14} \mathrm{R}_{f}=0.25,50: 50 \mathrm{Et}_{2} \mathrm{O} /$ hexanes; ${ }^{1} \mathrm{H}$ NMR $(500 \mathrm{MHz}$, $\left.\mathrm{CDCl}_{3}\right) \delta 7.31(\mathrm{~m}, 5 \mathrm{H}), 5.80(\mathrm{ddd}, J=16.5,11.1,7.7,1 \mathrm{H}), 5.28(\mathrm{~d}, J=16.5,1 \mathrm{H}), 5.27(\mathrm{~d}, J=$ $11.1,1 \mathrm{H}), 4.63(\mathrm{~d}, J=11.8,1 \mathrm{H}), 4.37(\mathrm{~d}, J=11.8,1 \mathrm{H}), 4.03(\mathrm{dt}, J=7.7,4.5,1 \mathrm{H}), 3.78(\mathrm{~m}, 2 \mathrm{H})$, $2.37(\mathrm{dd}, J=6.5,4.7,1 \mathrm{H}), 1.89(\mathrm{dddd}, J=14.8,7.7,7.1,4.4,1 \mathrm{H}), 1.80(\mathrm{dddd}, J=14.8,6.5,4.5$, $4.1,1 \mathrm{H}) ;{ }^{13} \mathrm{C}$ NMR $\left(125 \mathrm{MHz}, \mathrm{CDCl}_{3}\right) \delta 138.2,138.1,128.5,127.8,127.7,117.6,79.9,70.3$, $60.6,37.8$.

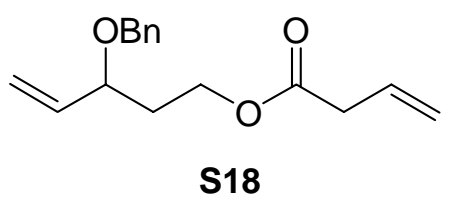

But-3-enoic acid 3-(benzyloxy)pent-4-enyl ester (S18): To a cooled $\left(0{ }^{\circ} \mathrm{C}\right)$ solution of $\mathrm{N}, \mathrm{N}$ dicyclohexylcarbodiimide $(0.321 \mathrm{~g}, 1.50 \mathrm{mmol})$ in $10 \mathrm{~mL}$ of anhydrous $\mathrm{CH}_{2} \mathrm{Cl}_{2}$ was added vinyl acetic acid $(0.145 \mathrm{~mL}, 1.70 \mathrm{mmol})$ dropwise by syringe. The flask was protected from light and stirred for $30 \mathrm{~min}$ at $0{ }^{\circ} \mathrm{C}$. A solution of 3-benzyloxy-4-penten-1-ol (S17) $(0.192 \mathrm{~g}, 1.00 \mathrm{mmol})$ in $6 \mathrm{~mL}$ of $\mathrm{CH}_{2} \mathrm{Cl}_{2}$ was added by cannula, and the mixture was stirred for $10 \mathrm{~min}$. Then, 4- $(\mathrm{N}, \mathrm{N}-$ dimethylamino)pyridine (0.046 $\mathrm{g}, 0.38 \mathrm{mmol})$ was added, and the solution was stirred for $90 \mathrm{~min}$ with warming to ambient temperature. The mixture was filtered, and the filtrate was 
concentrated. Purification by flash column chromatography on silica gel $(0: 100$ to 10:90 EtOAc/hexanes) afforded the product as a colorless oil $(0.240 \mathrm{~g}, 92 \%): \mathrm{R}_{f}=0.75,20: 80$ EtOAc/hexanes; ${ }^{1} \mathrm{H}$ NMR $\left(500 \mathrm{MHz}, \mathrm{CDCl}_{3}\right) \delta 7.30(\mathrm{~m}, 5 \mathrm{H}), 5.88(\mathrm{ddt}, J=16.2,9.2,7.0,1 \mathrm{H})$, $5.75(\mathrm{ddd}, J=18.4,10.7,7.7,1 \mathrm{H}), 5.26(\mathrm{ddd}, J=10.7,1.6,0.9,1 \mathrm{H}), 5.25(\mathrm{ddd}, J=18.4,1.6$, $0.9,1 \mathrm{H}), 5.14(\mathrm{ddd}, J=9.2,3.1,1.4,1 \mathrm{H}), 5.13(\mathrm{ddd}, J=16.2,3.1,1.4,1 \mathrm{H}), 4.59(\mathrm{~d}, J=11.8$ 1H), $4.34(\mathrm{~d}, J=11.8,1 \mathrm{H}), 4.24(\mathrm{ddd}, J=11.0,7.7,6.0,1 \mathrm{H}), 4.16(\mathrm{dt}, J=11.0,6.4,1 \mathrm{H}), 3.86$ (dddd, $J=8.0,7.7,5.1,0.9,1 \mathrm{H}), 3.03(\mathrm{dd}, J=7.0,1.4,1 \mathrm{H}), 3.02(\mathrm{dd}, J=7.0,1.4,1 \mathrm{H}), 1.95$ (dddd, $J=14.2,8.0,6.4,6.0,1 \mathrm{H}), 1.85$ (dddd, $J=14.2,7.7,6.4,5.1,1 \mathrm{H}) ;{ }^{13} \mathrm{C}$ NMR $(125 \mathrm{MHz}$, $\left.\mathrm{CDCl}_{3}\right) \delta 171.4,138.4,138.1,130.3,128.3,127.8,127.5,118.4,117.8,76.9,70.1,61.3,39.1$ 34.5; IR (neat) 3082, 2866, 1738, 1458, 1328, $1174 \mathrm{~cm}^{-1}$; HRMS $\left(\mathrm{CI} / \mathrm{NH}_{3}\right) \mathrm{m} / z$ calcd for $\mathrm{C}_{16} \mathrm{H}_{21} \mathrm{O}_{3}(\mathrm{M}+\mathrm{H})^{+}$261.1490, found 261.1482. Anal. Calcd for $\mathrm{C}_{16} \mathrm{H}_{20} \mathrm{O}_{3}$ : C, 73.82; H, 7.74. Found: C, 74.03; H, 7.79.

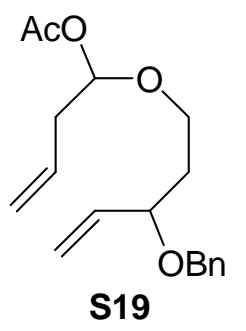

Acetic acid 1-(3-benzyloxypent-4-enyloxy)but-3-enyl ester $(\mathbf{S 1 9}):{ }^{4}$ To a cooled $\left(-78{ }^{\circ} \mathrm{C}\right)$ solution of ester $\mathbf{S 1 8}(0.130 \mathrm{~g}, 0.500 \mathrm{mmol})$ in $5 \mathrm{~mL}$ of $\mathrm{CH}_{2} \mathrm{Cl}_{2}$ was added ${ }^{i} \mathrm{Bu}_{2} \mathrm{AlH}(1.5 \mathrm{M}$ in toluene, $0.67 \mathrm{~mL}, 1.0 \mathrm{mmol}$ ) dropwise by syringe. After $45 \mathrm{~min}$, the reaction mixture was treated sequentially with pyridine $(0.121 \mathrm{~mL}, 1.50 \mathrm{mmol})$ dropwise by syringe, neat $4-(N, N-$ dimethylamino)pyridine $(0.122 \mathrm{~g}, 1.00 \mathrm{mmol})$, and $\mathrm{Ac}_{2} \mathrm{O}(0.283 \mathrm{~mL}, 3.00 \mathrm{mmol})$ dropwise by syringe. The mixture was stirred at $-78{ }^{\circ} \mathrm{C}$ for $12 \mathrm{~h}$, warmed to $0{ }^{\circ} \mathrm{C}$, and stirred for an additional $30 \mathrm{~min}$. After $30 \mathrm{~min}$, saturated aqueous $\mathrm{NH}_{4} \mathrm{Cl}(10 \mathrm{~mL})$ and saturated aqueous 
sodium potassium tartrate $(10 \mathrm{~mL})$ were added. The resulting mixture was then warmed to ambient temperature, and was stirred vigorously for $1 \mathrm{~h}$ before $10 \mathrm{~mL}$ of brine was added. After the layers were separated, the aqueous layer was extracted with $5 \times 5 \mathrm{~mL}$ of EtOAc. The combined organic extracts were washed with ice-cold $1.0 \mathrm{M} \mathrm{NaHSO}_{4}(2 \times 5 \mathrm{~mL})$, saturated $\mathrm{NaHCO}_{3}(3 \times 5 \mathrm{~mL})$, and brine $(10 \mathrm{~mL})$, and then were dried over anhydrous $\mathrm{MgSO}_{4}$, filtered, and concentrated in vacuo. Purification by flash column chromatography on deactivated silica gel (0:100 to 20:80 $\mathrm{Et}_{2} \mathrm{O} /$ hexanes) afforded the product as a colorless and inseparable 1:0.8 mixture of diastereomers $(0.124 \mathrm{~g}, 82 \%): \mathrm{R}_{f}=0.45,20: 80 \mathrm{EtOAc} /$ hexanes; ${ }^{1} \mathrm{H}$ NMR $(500 \mathrm{MHz}$, $\left.\mathrm{CDCl}_{3}\right) \delta 7.35-7.26(\mathrm{~m}, 9 \mathrm{H}), 5.80(\mathrm{dd}, J=5.7,5.2,1 \mathrm{H}), 5.78-5.67(\mathrm{~m}, 4.4 \mathrm{H}), 5.28-5.21(\mathrm{~m}$, $3.6 \mathrm{H}), 5.14-5.07(\mathrm{~m}, 3.6 \mathrm{H}), 4.59(2 \mathrm{~d}$ 's $, J=11.7,1.8 \mathrm{H}), 4.36(\mathrm{~d}, J=11.7,1 \mathrm{H}), 4.33(\mathrm{~d}, J=11.7$, $0.8 \mathrm{H}), 3.91(\mathrm{~m}, 1.8 \mathrm{H}), 3.81(\mathrm{ddd}, J=9.5,6.9,6.0,1 \mathrm{H}), 3.72(\mathrm{dt}, J=9.5,5.7,0.8 \mathrm{H}), 3.63(\mathrm{ddd}, J$ $=9.5,7.9,5.4,0.8 \mathrm{H}), 3.55(\mathrm{dt}, J=9.5,6.2,1 \mathrm{H}), 2.48-2.35(\mathrm{~m}, 3.6 \mathrm{H}), 2.06(\mathrm{~s}, 2.4 \mathrm{H}), 2.05(\mathrm{~s}$, $3 \mathrm{H}), 1.96-1.84(\mathrm{~m}, 1.8 \mathrm{H}), 1.78(\mathrm{~m}, 1.8 \mathrm{H}) ;{ }^{13} \mathrm{C} \mathrm{NMR}\left(125 \mathrm{MHz}, \mathrm{CDCl}_{3}\right) \delta 170.72,170.70$ $138.60,138.57,138.4,131.74,131.72,128.34,128.30,127.8,127.7,127.5,127.4,118.48$ 118.45, 117.6, 117.4, 97.8, 97.7, 77.4, 77.2, 70.24, 70.17, 65.64, 65.58, 38.99, 38.97, 35.5, 35.4, 21.13, 21.12; IR (neat) 3079, 2932, 2881, 1740, 1373, $1238 \mathrm{~cm}^{-1}$; HRMS (EI+) $\mathrm{m} / z$ calcd for $\mathrm{C}_{16} \mathrm{H}_{20} \mathrm{O}_{2}\left(\mathrm{M}-\mathrm{C}_{2} \mathrm{H}_{4} \mathrm{O}_{2}\right)^{+}$244.1463, found 244.1463. Anal. Calcd for $\mathrm{C}_{18} \mathrm{H}_{24} \mathrm{O}_{4}: \mathrm{C}, 71.03 ; \mathrm{H}$, 7.95. Found: C, 71.20; H, 7.86.

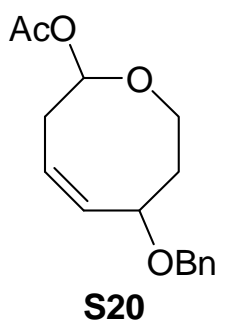


Acetic acid (Z)-6-benzyloxy-3,6,7,8-tetrahydro-2H-oxocin-2-yl ester (S20): ${ }^{16}$ A solution of diene $\mathbf{S 1 9}(0.176 \mathrm{~g}, 0.578 \mathrm{mmol})$ in $193 \mathrm{~mL}$ of $\mathrm{CH}_{2} \mathrm{Cl}_{2}$ was degassed for $1 \mathrm{~h}$, then was heated to reflux. Grubbs' catalyst ${ }^{17}(0.024 \mathrm{~g}, 0.029 \mathrm{mmol})$ was added, and the light purple solution was heated at reflux for $8 \mathrm{~h}$ during which time the solution gained a tan hue. After $8 \mathrm{~h}$, another 5 mol\% of catalyst was added, and the solution was heated at reflux for an additional $12 \mathrm{~h}$. The solution was then cooled to ambient temperature, and DMSO $(0.41 \mathrm{~mL})$ was added to deactivate the catalyst. After $8 \mathrm{~h}$, the solution was concentrated and purified by flash column chromatography on deactivated silica gel (10:90 to 30:70 EtOAc/hexanes) to afford the product (determined by ${ }^{1} \mathrm{H}$ NMR to be an approximate 60:40 mixture of diastereomers) as a colorless liquid $(0.169 \mathrm{~g}, 99 \%): \mathrm{R}_{f}=0.32,20: 80$ EtOAc/hexanes; ${ }^{1} \mathrm{H}$ NMR $\left(500 \mathrm{MHz}, \mathrm{CDCl}_{3}\right) \delta 7.37-$ $7.26(\mathrm{~m}, 12.5 \mathrm{H}), 5.96(\mathrm{dd}, J=6.0,3.0,1 \mathrm{H}), 5.86(\mathrm{dd}, J=10.0,6.6,1.5 \mathrm{H}$ and $\mathrm{m}, 1 \mathrm{H}), 5.75(\mathrm{ddd}$, $J=10.0,9.6,7.9,1.5 \mathrm{H}$ and $\mathrm{m}, 1 \mathrm{H}), 5.69(\mathrm{dd}, J=10.2,2.2,1.5 \mathrm{H}), 4.63(\mathrm{~d}, J=11.7,1 \mathrm{H}), 4.62(\mathrm{~d}$, $J=11.9,1.5 \mathrm{H}), 4.44(\mathrm{~d}, J=11.9,1.5 \mathrm{H}), 4.42(\mathrm{~d}, J=11.7,1 \mathrm{H}), 4.40(\mathrm{ddd}, J=10.2,6.6,5.0$ $1.5 \mathrm{H}), 4.31(\mathrm{~m}, 1 \mathrm{H}), 4.20(\mathrm{ddd}, J=12.7,10.6,2.3,1 \mathrm{H}), 4.03(\mathrm{ddd}, J=12.9,7.1,3.6,1.5 \mathrm{H}), 3.64$ $(\mathrm{ddd}, J=12.9,7.9,3.4,1.5 \mathrm{H}), 3.56(\mathrm{dt}, J=12.7,4.1,1 \mathrm{H}), 2.52(\mathrm{ddd}, J=13.6,10.2,9.6,1.5 \mathrm{H})$, $2.38(\mathrm{ddd}, J=14.2,6.0,3.0,1 \mathrm{H}), 2.28(\mathrm{ddd}, J=14.2,7.9,2.2,1.5 \mathrm{H}), 2.14(\mathrm{dddd}, J=14.2,7.9$, 5.0, 3.6, $1.5 \mathrm{H}$ and $\mathrm{m}, 1 \mathrm{H}), 2.08(\mathrm{~s}, 3 \mathrm{H}), 2.06(\mathrm{~s}, 4.5 \mathrm{H}), 1.76$ (dddd, $J=14.2,10.2,7.1,3.4,1.5 \mathrm{H}$, and $\mathrm{m}, 1 \mathrm{H}) ;{ }^{13} \mathrm{C}$ NMR $\left(125 \mathrm{MHz}, \mathrm{CDCl}_{3}\right) \delta 169.6,138.2,128.4,127.8,127.7,127.6,123.7$, 96.6, 75.4, 70.8, 63.1, 36.8, 36.1, 32.3, 21.2; IR (thin film) 3031, 2957, 1743, 1548, 1372, 1234 $\mathrm{cm}^{-1}$; HRMS $\left(\mathrm{CI} / \mathrm{NH}_{3}\right) \mathrm{m} / z$ calcd for $\mathrm{C}_{14} \mathrm{H}_{17} \mathrm{O}_{3}\left(\mathrm{M}-\mathrm{C}_{2} \mathrm{H}_{3} \mathrm{O}\right)^{+}$233.1178, found 233.1172. 


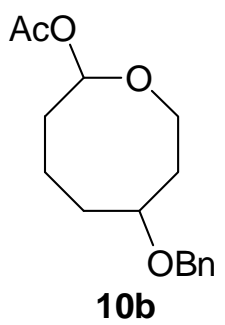

Acetic acid 6-benzyloxy-oxocan-2-yl ester $(\mathbf{1 0 b}):^{16}$ To a pale yellow solution of oxocene $\mathbf{S 2 0}$ $(0.169 \mathrm{~g}, \quad 0.612 \mathrm{mmol})$ in $41 \mathrm{~mL}$ of $\mathrm{CH}_{2} \mathrm{Cl}_{2}$ was added a solution of (tricyclohexylphosphine)(1,5-cyclooctadiene)(pyridine)iridium(I) hexafluorophosphate ${ }^{18}(0.005$ $\mathrm{g}, 0.00612 \mathrm{mmol}$ ) in $2 \mathrm{~mL}$ of $\mathrm{CH}_{2} \mathrm{Cl}_{2}$. The $\mathrm{N}_{2}$ atmosphere was quickly replaced using a balloon filled with $\mathrm{H}_{2}$, and the orange color formed upon addition of catalyst and $\mathrm{H}_{2}$ degraded within 510 minutes. The reaction mixture was stirred at ambient temperature and monitored by GC. After $15 \mathrm{~h}$ and after $17 \mathrm{~h}$, another $2 \mathrm{~mol} \%$ of catalyst solution in $2 \mathrm{~mL}$ of $\mathrm{CH}_{2} \mathrm{Cl}_{2}$ was added, and the reaction reached $60 \%$ conversion. After $36 \mathrm{~h}$, a solution of $6 \mathrm{~mol} \%$ of the catalyst in $3 \mathrm{~mL}$ of $\mathrm{CH}_{2} \mathrm{Cl}_{2}$ was added dropwise by syringe over $6 \mathrm{~h}$. After $2 \mathrm{~mL}$ of this solution was added, the reaction reached $90 \%$ conversion. The remainder of the catalyst solution $(1 \mathrm{~mL}$ containing 2 mol\% of the catalyst) was added and the mixture was stirred for an additional $12 \mathrm{~h}$. Even after $12 \mathrm{~h}$, the orange color persisted, and the reaction was judged complete by GC. The solution was concentrated in vacuo, then was purified by flash chromatography on deactivated silica gel (10:90 to 20:80 EtOAc/hexanes) to afford the product (determined by GC to be a 60:40 mixture of diastereomers) as a colorless oil $(0.169 \mathrm{~g}, 99 \%): \mathrm{R}_{f}=0.43,20: 80 \mathrm{EtOAc} / \mathrm{hexanes} ;{ }^{1} \mathrm{H}$ NMR $\left(500 \mathrm{MHz}, \mathrm{CDCl}_{3}\right) \delta$ 7.36-7.26 (m, 7.5H), $5.80(\mathrm{dd}, J=6.6,4.7,1.5 \mathrm{H}), 5.74(\mathrm{dd}, J=10.1,2.9$, $1 \mathrm{H}), 4.53(\mathrm{~d}, J=12.1,1.5 \mathrm{H}$, and $\mathrm{m}, 1 \mathrm{H}), 4.48(\mathrm{~d}, J=12.1,1.5 \mathrm{H}$, and $\mathrm{m}, 1 \mathrm{H}), 4.12(\mathrm{ddd}, J=$ $12.4,10.0,3.3,1 \mathrm{H}), 4.04(\mathrm{dt}, J=12.5,4.0,1.5 \mathrm{H}), 3.86(\mathrm{dt}, J=12.4,4.6,1 \mathrm{H}), 3.78(\mathrm{ddd}, J=$ 12.5, 12.1, 2.9, 1.5H), $3.62(\mathrm{~m}, 1.5 \mathrm{H}$ and $\mathrm{m}, 1 \mathrm{H}), 2.09(\mathrm{~m}, 3.5 \mathrm{H}), 2.06(\mathrm{~s}, 3 \mathrm{H}), 2.05(\mathrm{~s}, 4.5 \mathrm{H})$, $2.00(\mathrm{~m}, 2.5 \mathrm{H}), 1.92-1.83(\mathrm{~m}, 4.5 \mathrm{H}), 1.76-1.70(\mathrm{~m}, 5.5 \mathrm{H}), 1.68-1.64(\mathrm{~m}, 3 \mathrm{H}) ;{ }^{13} \mathrm{C}$ NMR $(125$ 
$\left.\mathrm{MHz}, \mathrm{CDCl}_{3}\right) \delta 170.33(2), 138.86(2), 128.42,128.36,128.35,127.44,127.41,127.39,97.7$, $97.3,77.8,76.4,70.4,70.0,64.8,64.7,33.3,33.2,32.8,32.3,32.1,31.1,21.3,21.2,20.7,18.1$; IR (thin film) 2923, 1734, 1458, 1364, 1236, $1016 \mathrm{~cm}^{-1} ; \mathrm{HRMS}\left(\mathrm{CI} / \mathrm{NH}_{3}\right) \mathrm{m} / z$ calcd for $\mathrm{C}_{16} \mathrm{H}_{23} \mathrm{O}_{4}(\mathrm{M}+\mathrm{H})^{+} 279.1596$, found 279.1602 .

\section{IIE. Synthesis of Acetic acid 4-methyloxocan-2-yl ester (15a)}
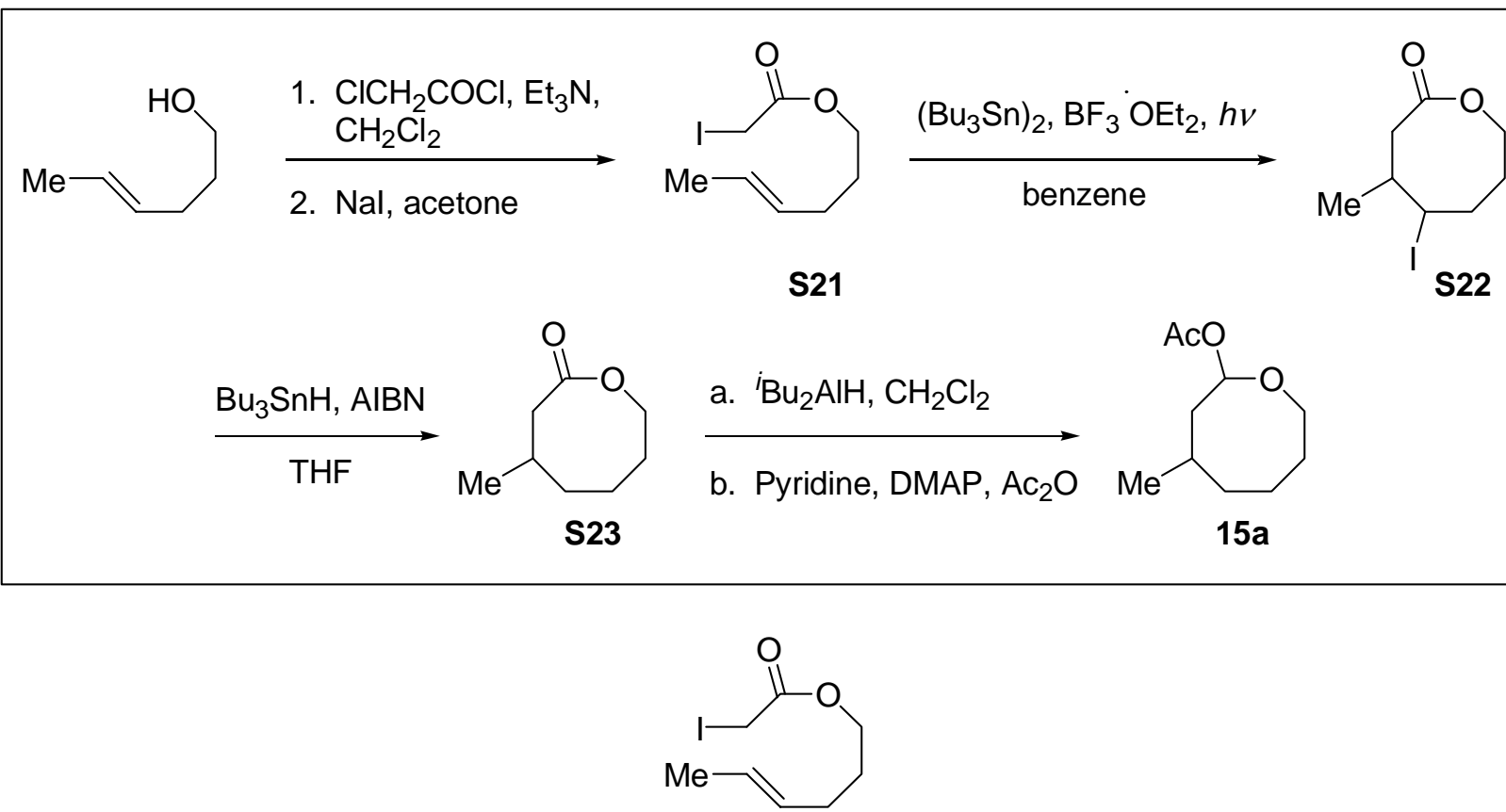

S21

Iodoacetic acid hex-4-enyl ester (S21): ${ }^{19}$ To a cooled $\left(0{ }^{\circ} \mathrm{C}\right)$ solution of 4-hexen-1-ol (11.8 $\mathrm{mL}, 0.100 \mathrm{~mol}$, mostly trans $)$ and $\mathrm{Et}_{3} \mathrm{~N}(15.3 \mathrm{~mL}, 0.110 \mathrm{~mol})$ in $100 \mathrm{~mL}$ of $\mathrm{CH}_{2} \mathrm{Cl}_{2}$ was added chloroacetyl chloride $(8.8 \mathrm{~mL}, 0.110 \mathrm{~mol})$ dropwise by syringe. The mixture was stirred for $12 \mathrm{~h}$ with warming to ambient temperature, and then it was vacuum-filtered through a sintered-glass funnel. The filtrate was washed with $40 \mathrm{~mL}$ of water. The layers were then separated, and the organic portion was dried over anhydrous $\mathrm{MgSO}_{4}$, filtered, and concentrated in vacuo. The resulting liquid was transferred by syringe to a solution of $\mathrm{NaI}(22.5 \mathrm{~g}, 0.150 \mathrm{~mol})$ in $100 \mathrm{~mL}$ of 
acetone, and the mixture was stirred at ambient temperature for $5 \mathrm{~h}$. The solution was concentrated in vacuo, suspended in $90 \mathrm{~mL}$ of $\mathrm{Et}_{2} \mathrm{O}$, and then washed successively with $20 \mathrm{~mL}$ of water, $10 \mathrm{~mL}$ of saturated aqueous $\mathrm{NaHCO}_{3}$, and $20 \mathrm{~mL}$ of brine. The combined organic extracts were dried over anhydrous $\mathrm{MgSO}_{4}$, filtered, and concentrated in vacuo. The resulting liquid was distilled under high vacuum (bp $78-80^{\circ} \mathrm{C}$ ) to afford the product as an orange liquid $(21.39 \mathrm{~g}, 80 \%):{ }^{1} \mathrm{H} \mathrm{NMR}\left(500 \mathrm{MHz}, \mathrm{CDCl}_{3}\right) \delta 5.44(\mathrm{~m}, 2 \mathrm{H}), 4.14(\mathrm{t}, J=6.6,2 \mathrm{H}), 3.69(\mathrm{~s}, 2 \mathrm{H})$, $2.08(\mathrm{dq}, J=6.6,1.2,2 \mathrm{H}), 1.71$ (quint, $J=6.6,2 \mathrm{H}), 1.65(\mathrm{dd}, J=6.0,1.2,3 \mathrm{H}) ;{ }^{13} \mathrm{C}$ NMR $(125$ $\left.\mathrm{MHz}, \mathrm{CDCl}_{3}\right) \delta 168.8,129.7,126.1,65.5,28.6,28.1,17.9,-5.4$; IR (neat) 2958, 2853, 1735, 1416, 1264, $1092 \mathrm{~cm}^{-1}$; HRMS $\left(\mathrm{CI} / \mathrm{NH}_{3}\right) \mathrm{m} / z$ calcd for $\mathrm{C}_{8} \mathrm{H}_{14} \mathrm{O}_{2} \mathrm{I}(\mathrm{M}+\mathrm{H})^{+}$269.0040, found 269.0028. Anal. Calcd for $\mathrm{C}_{8} \mathrm{H}_{13} \mathrm{O}_{2} \mathrm{I}$ : C, 35.84; H, 4.89. Found: C, 36.21; H, 5.03.

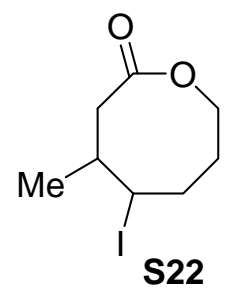

5-Iodo-4-methyloxocan-2-one (S22): ${ }^{19}$ A solution of iodoacetic acid hex-4-enyl ester (S21) (5.36 g, $20.0 \mathrm{mmol}), \mathrm{BF}_{3} \cdot \mathrm{OEt}_{2}(7.6 \mathrm{~mL}, 60 \mathrm{mmol})$, and bis(tributyltin) $(1.0 \mathrm{~mL}, 2.0 \mathrm{mmol})$ in $650 \mathrm{~mL}$ of anhydrous benzene was irradiated for $4 \mathrm{~h}$ with a $500 \mathrm{~W}$ sun lamp (kept at least $30 \mathrm{~cm}$ from the reaction flask). The solution was then concentrated in vacuo and purified by flash column chromatography on deactivated silica gel (40:60 EtOAc/hexanes) to afford a moisture and light-sensitive, colorless oil. This oil was dissolved in $100 \mathrm{~mL}$ of anhydrous $\mathrm{CH}_{3} \mathrm{CN}$ and was extracted with $3 \times 30 \mathrm{~mL}$ of hexanes to remove tin residues. The $\mathrm{CH}_{3} \mathrm{CN}$ portion was concentrated in vacuo to afford the product as a colorless oil and as an approximate 1.5:1 mixture of diastereomers $(2.24 \mathrm{~g}, 42 \%):{ }^{1} \mathrm{H} \mathrm{NMR}\left(500 \mathrm{MHz}, \mathrm{C}_{6} \mathrm{D}_{6}\right) \delta 4.06(\mathrm{ddd}, J=12.5,8.9$, 
$4.0,1 \mathrm{H}), 3.92(\mathrm{dt}, J=7.6,1.3,1 \mathrm{H}), 3.69(\mathrm{td}, J=7.8,1.6,1.5 \mathrm{H}), 3.68-3.63(\mathrm{~m}, 3 \mathrm{H}), 3.51(\mathrm{dt}, J=$ $12.5,5.2,1 \mathrm{H}), 2.38(\mathrm{dd}, J=13.7,3.9,1.5 \mathrm{H}), 2.07(\mathrm{qt}, J=7.1,3.9,1.5 \mathrm{H}), 2.01(\mathrm{dd}, J=13.7$, $10.5,1.5 \mathrm{H}), 1.88(\mathrm{ddd}, J=13.7,3.6,0.8,1 \mathrm{H}), 1.74(\mathrm{dd}, J=13.7,7.1,1.5 \mathrm{H}), 1.63-1.33(\mathrm{~m}, 6 \mathrm{H})$, $1.30-1.15(\mathrm{~m}, 5 \mathrm{H}), 0.94(\mathrm{~d}, J=6.9,4.5 \mathrm{H}), 0.70(\mathrm{~d}, J=6.7,3 \mathrm{H}) ;{ }^{13} \mathrm{C} \mathrm{NMR}\left(125 \mathrm{MHz}, \mathrm{C}_{6} \mathrm{D}_{6}\right) \delta$ 174.0, 172.5, 66.7, 66.2, 42.0, 40.72, 40.65, 38.2, 34.9, 32.8, 31.7, 31.0, 30.9, 23.7, 22.3; IR (neat) $2958,2871,1732,1455,1384,1181 \mathrm{~cm}^{-1} ; \operatorname{HRMS}\left(\mathrm{CI} / \mathrm{NH}_{3}\right) \mathrm{m} / z$ calcd for $\mathrm{C}_{8} \mathrm{H}_{12} \mathrm{OI}(\mathrm{M}-$ $\mathrm{OH})^{+} 250.9933$, found 250.9927 .

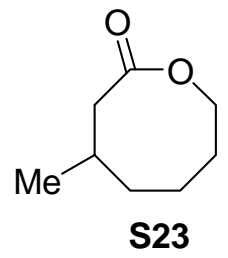

4-Methyloxocan-2-one (S23): ${ }^{20} \quad$ A solution of 5-iodo-4-methyloxocan-2-one $(2.24 \mathrm{~g}, 8.36$ mmol), $n-\mathrm{Bu}_{3} \mathrm{SnH}(2.35 \mathrm{~mL}, 8.78 \mathrm{mmol})$, and $\operatorname{AIBN}(0.137 \mathrm{~g}, 0.84 \mathrm{mmol})$ in $85 \mathrm{~mL}$ of anhydrous THF was heated at reflux for $16 \mathrm{~h}$. The solution was then cooled to ambient temperature, concentrated in vacuo, and suspended in $200 \mathrm{~mL}$ of anhydrous $\mathrm{CH}_{3} \mathrm{CN}$. This solution was extracted with $10 \times 35 \mathrm{~mL}$ of hexanes to facilitate removal of tin residues, then was concentrated in vacuo to afford the product as a colorless liquid $(1.18 \mathrm{~g}, 99 \%): \mathrm{R}_{f}=0.33,30: 70$ EtOAc/hexanes; ${ }^{1} \mathrm{H}$ NMR $\left(500 \mathrm{MHz}, \mathrm{CDCl}_{3}\right) \delta 4.34(\mathrm{~m}, 2 \mathrm{H}), 2.54(\mathrm{dd}, J=12.2,4.2,1 \mathrm{H}), 2.35$ $(\mathrm{dd}, J=12.2,9.8,1 \mathrm{H}), 2.06(\mathrm{~m}, 1 \mathrm{H}), 1.89(\mathrm{~m}, 1 \mathrm{H}), 1.81(\mathrm{~m}, 1 \mathrm{H}), 1.77(\mathrm{~m}, 1 \mathrm{H}), 1.68(\mathrm{~m}, 1 \mathrm{H})$ $1.35(\mathrm{~m}, 1 \mathrm{H}), 1.25(\mathrm{~m}, 1 \mathrm{H}), 1.06(\mathrm{~d}, J=6.8,3 \mathrm{H}) ;{ }^{13} \mathrm{C} \mathrm{NMR}\left(125 \mathrm{MHz}, \mathrm{CDCl}_{3}\right) \delta 175.4,67.8$ 37.7, 34.5, 33.8, 31.0, 22.6, 21.8; IR (neat) 2932, 2872, 1729, 1459, 1310, $1231 \mathrm{~cm}^{-1}$; HRMS (EI) $m / z$ calcd for $\mathrm{C}_{8} \mathrm{H}_{15} \mathrm{O}_{2}\left(\mathrm{M}^{+}\right)$142.0994, found 142.0991. Anal. Calcd for $\mathrm{C}_{8} \mathrm{H}_{14} \mathrm{O}_{2}: \mathrm{C}$, 67.57; H, 9.92. Found: C, 67.19; H, 9.82. 


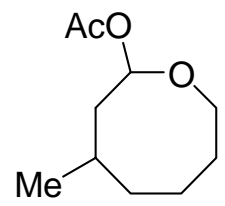

$15 a$

Acetic acid 4-methyloxocan-2-yl ester (15a): ${ }^{4}$ To a cooled $\left(-78{ }^{\circ} \mathrm{C}\right)$ solution of $4-$ methyloxocan-2-one $(0.270 \mathrm{~g}, 1.90 \mathrm{mmol})$ in $20 \mathrm{~mL}$ of $\mathrm{CH}_{2} \mathrm{Cl}_{2}$ was slowly added ${ }^{i} \mathrm{Bu}_{2} \mathrm{AlH}(1.5$ $\mathrm{M}$ in toluene, $2.5 \mathrm{~mL}, 3.8 \mathrm{mmol}$ ) dropwise by syringe. After $45 \mathrm{~min}$, the reaction mixture was treated sequentially with pyridine $(0.46 \mathrm{~mL}, 5.7 \mathrm{mmol})$ dropwise by syringe, neat $4-(N, N-$ dimethylamino)pyridine $(0.464 \mathrm{~g}, 3.80 \mathrm{mmol})$, and $\mathrm{Ac}_{2} \mathrm{O}(1.10 \mathrm{~mL}, 11.4 \mathrm{mmol})$ dropwise by syringe. The mixture was stirred at $-78^{\circ} \mathrm{C}$ for $12 \mathrm{~h}$, then was warmed to $0{ }^{\circ} \mathrm{C}$ and stirred for 30 min. Then, a mixture of saturated aqueous $\mathrm{NH}_{4} \mathrm{Cl}(10 \mathrm{~mL})$ and saturated aqueous sodium potassium tartrate $(10 \mathrm{~mL})$ was added. The resulting mixture was warmed to ambient temperature and stirred vigorously for $1 \mathrm{~h}$ before $10 \mathrm{~mL}$ of brine was added. After the layers were separated, the aqueous portion was extracted with $5 \times 5 \mathrm{~mL}$ of $\mathrm{Et}_{2} \mathrm{O}$. The combined organic extracts were washed with ice-cold $1 \mathrm{M} \mathrm{NaHSO}_{4}(2 \times 5 \mathrm{~mL})$, saturated aqueous $\mathrm{NaHCO}_{3}(3 \times 5 \mathrm{~mL})$, and brine $(1 \times 10 \mathrm{~mL})$, then were dried over anhydrous $\mathrm{MgSO}_{4}$, filtered, and concentrated in vacuo. Purification by flash column chromatography on deactivated silica gel (10:90 to $30: 70 \mathrm{Et}_{2} \mathrm{O} /$ pentane) afforded the product (determined by $\mathrm{GC}$ to be a 61:39 ratio of diastereomers) as a volatile pale yellow oil (0.097 $\mathrm{g}, 27 \%): \mathrm{R}_{f}=0.54,30: 70 \mathrm{EtOAc} / \mathrm{hexanes}$; GC $t_{\mathrm{R}}$ (major) $8.57 \mathrm{~min}, t_{\mathrm{R}}$ (minor) $8.62 \mathrm{~min}\left(50{ }^{\circ} \mathrm{C}\right.$ for $1 \mathrm{~min}, 10 \% \mathrm{~min}$, to $\left.150{ }^{\circ} \mathrm{C}\right):{ }^{1} \mathrm{H} \mathrm{NMR}$ $\left(500 \mathrm{MHz}, \mathrm{CDCl}_{3}\right) \delta 6.02(\mathrm{dd}, J=10.3,3.6,0.8 \mathrm{H}), 5.85(\mathrm{dd}, J=10.1,2.6,1 \mathrm{H}), 3.94(\mathrm{dt}, J=$ $12.3,3.6,0.8 \mathrm{H}), 3.92(\mathrm{dt}, J=12.2,3.7,1 \mathrm{H}), 3.83(\mathrm{ddd}, J=12.2,5.3,3.7,1 \mathrm{H}), 3.78(\mathrm{ddd}, J=$ 12.3, 5.6, 3.9, 0.8H), 2.09 (ddd, $J=14.4,10.4,4.2,1 \mathrm{H}), 2.051(\mathrm{~s}, 2.4 \mathrm{H}), 2.047$ (s, 3H), 1.95$1.88(\mathrm{~m}, 0.8 \mathrm{H}), 1.76-1.59(\mathrm{~m}, 9 \mathrm{H}), 1.57-1.47(\mathrm{~m}, 3.4 \mathrm{H}), 1.45(\mathrm{ddd}, J=14.4,7.3,3.6,1 \mathrm{H}), 1.36$ 
$(\mathrm{dtd}, J=11.7,4.6,2.0,1 \mathrm{H}), 1.00(\mathrm{~d}, J=7.0,2.4 \mathrm{H}), 0.95(\mathrm{~d}, J=6.6,3 \mathrm{H}) ;{ }^{13} \mathrm{C}$ NMR $(125 \mathrm{MHz}$, $\left.\mathrm{CDCl}_{3}\right) \delta 170.3,170.2,98.0,94.9,68.2,67.4,39.6,37.1,34.6,34.2,30.6,29.9,29.7,29.2,24.6$, 24.2, 23.8, 21.9, 21.2 (2); IR (neat) 2953, 2873, 1743, 1458, 1369, $1242 \mathrm{~cm}^{-1}$; HRMS (EI) $\mathrm{m} / z$ calcd for $\mathrm{C}_{9} \mathrm{H}_{15} \mathrm{O}_{3}\left(\mathrm{M}-\mathrm{CH}_{3}\right)^{+}$171.1021, found 171.1022.

IIF. Synthesis of Acetic acid 4-(benzyloxy)oxocan-2-yl ester (15b)
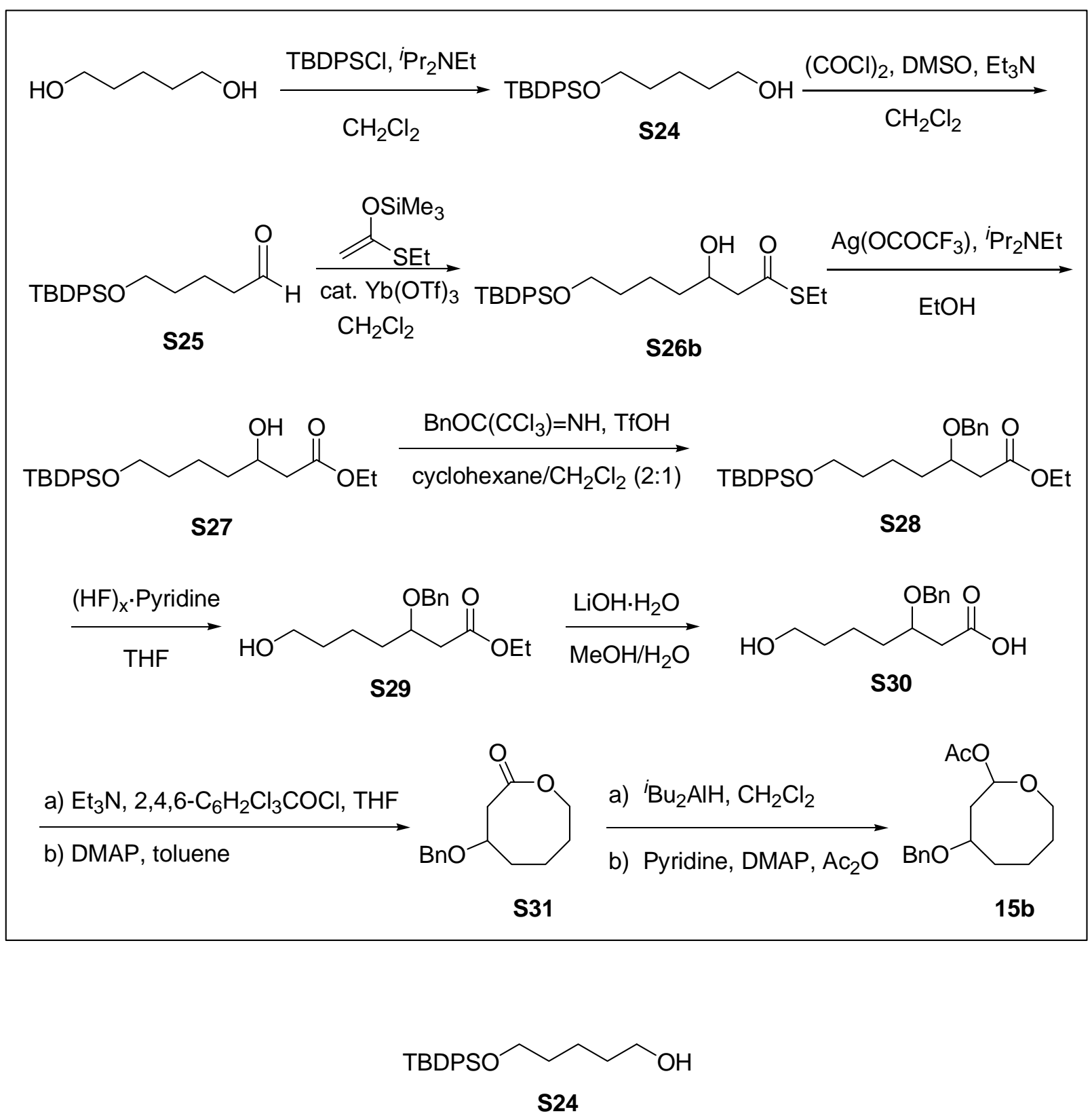
5-[(tert-Butyldiphenylsilyl)oxy]pentan-1-ol (S24): ${ }^{6}$ To a solution of 1,5-pentanediol $(46.6 \mathrm{~mL}$, $0.445 \mathrm{~mol})$ and imidazole $(31.66 \mathrm{~g}, 0.4656 \mathrm{~mol})$ in $\mathrm{CH}_{2} \mathrm{Cl}_{2}(500 \mathrm{~mL})$ at $0{ }^{\circ} \mathrm{C}$ was added tertbutylchlorodiphenylsilane $(32.0 \mathrm{~mL}, 0.123 \mathrm{~mol})$ dropwise by syringe. After stirring for $2 \mathrm{~h}$ with warming to ambient temperature, the reaction mixture was partitioned between $500 \mathrm{~mL}$ of $\mathrm{H}_{2} \mathrm{O}$ and $500 \mathrm{~mL}$ of $\mathrm{CH}_{2} \mathrm{Cl}_{2}$ and the layers were separated. The aqueous portion was extracted with 3 $\times 100 \mathrm{~mL}$ of $\mathrm{CH}_{2} \mathrm{Cl}_{2}$. The combined organic extracts were washed with $1.0 \mathrm{M} \mathrm{HCl}(2 \times 100$ $\mathrm{mL}$ ) and $100 \mathrm{~mL}$ of brine, then were dried over anhydrous $\mathrm{MgSO}_{4}$, filtered, and concentrated in vacuo. Purification by flash column chromatography on silica gel (10:90 to 30:70 EtOAc/hexanes) afforded the product as a colorless oil (35.81 g, 85\%). The spectral data correlates with the previously reported data for $\mathbf{S 2 4}:{ }^{21} \mathrm{R}_{f}=0.38,40: 60 \mathrm{Et}_{2} \mathrm{O} /$ pentane; ${ }^{1} \mathrm{H}$ NMR $\left(500 \mathrm{MHz}, \mathrm{CDCl}_{3}\right) \delta 7.67(\mathrm{dd}, J=7.7,1.5,4 \mathrm{H}), 7.36(\mathrm{~m}, 6 \mathrm{H}), 3.67(\mathrm{t}, J=6.6,2 \mathrm{H}), 3.55(\mathrm{t}, J=$ 6.6, 2H), 2.24 (br s, 1H), 1.58 (quint, $J=6.6,2 \mathrm{H}$ ), 1.51 (quint, $J=6.6,2 \mathrm{H}$ ), $1.40(\mathrm{~m}, 2 \mathrm{H}), 1.06$ (s, 9H); ${ }^{13} \mathrm{C} \mathrm{NMR}\left(125 \mathrm{MHz}, \mathrm{CDCl}_{3}\right) \delta 135.4,133.9,129.4,127.5,63.7,62.6,32.3,32.226 .8$, 21.9, 19.1; HRMS $\left(\mathrm{CI} / \mathrm{NH}_{3}\right) \mathrm{m} / \mathrm{z}$ calcd for $\mathrm{C}_{21} \mathrm{H}_{31} \mathrm{O}_{2} \mathrm{Si}(\mathrm{M}+\mathrm{H})^{+}$343.2093, found 343.2101.

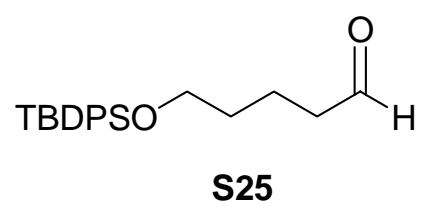

5-[(tert-Butyldiphenylsilyl)oxy]pentanal $(\mathbf{S 2 5}):{ }^{6}$ To a cooled $\left(-78{ }^{\circ} \mathrm{C}\right)$ solution of oxalyl chloride $(10.0 \mathrm{~mL}, 0.115 \mathrm{~mol})$ in $600 \mathrm{~mL}$ of $\mathrm{CH}_{2} \mathrm{Cl}_{2}$ was added dimethyl sulfoxide $(16.4 \mathrm{~mL}$, $0.231 \mathrm{~mol})$ dropwise by syringe. The mixture was allowed to stir for $5 \mathrm{~min}$ before a cooled ( -78 $\left.{ }^{\circ} \mathrm{C}\right)$ solution of alcohol $\mathbf{S 2 4}(35.81 \mathrm{~g}, 0.105 \mathrm{~mol})$ in $400 \mathrm{~mL}$ of $\mathrm{CH}_{2} \mathrm{Cl}_{2}$ was introduced by cannula. After $15 \mathrm{~min}, \mathrm{Et}_{3} \mathrm{~N}(57.2 \mathrm{~mL}, 0.525 \mathrm{~mol})$ was added by syringe, and the mixture was allowed to stir at $-78{ }^{\circ} \mathrm{C}$ for $10 \mathrm{~min}$. Upon warming to ambient temperature, $200 \mathrm{~mL}$ of $\mathrm{H}_{2} \mathrm{O}$ 
was added. The layers were separated, and then the aqueous layer was extracted with $3 \times 20 \mathrm{~mL}$ of $\mathrm{CH}_{2} \mathrm{Cl}_{2}$. The combined organic extracts were washed with $2 \times 100 \mathrm{~mL}$ of $1.0 \mathrm{M} \mathrm{HCl}$ and with $50 \mathrm{~mL}$ of brine, dried over $\mathrm{MgSO}_{4}$, then were filtered and concentrated in vacuo. The resulting oil was purified by flash column chromatography on silica gel (50:50 EtOAc/hexanes) to afford the product as a pale yellow oil $(35.03 \mathrm{~g}, 98 \%)$. The spectral data correlates with the previously reported data for $\mathbf{S 2 5}:{ }^{21} \mathrm{R}_{f}=0.42,10: 90 \mathrm{Et}_{2} \mathrm{O} /$ pentane; ${ }^{1} \mathrm{H}$ NMR $\left(500 \mathrm{MHz}, \mathrm{CDCl}_{3}\right) \delta 9.73(\mathrm{t}, J$ $=1.8,1 \mathrm{H}), 7.66(\mathrm{~m}, 4 \mathrm{H}), 7.40(\mathrm{~m}, 6 \mathrm{H}), 3.67(\mathrm{t}, J=6.2,2 \mathrm{H}), 2.40(\mathrm{dt}, J=7.3,1.8,2 \mathrm{H}), 1.73(\mathrm{~m}$, 2H), $1.58(\mathrm{~m}, 2 \mathrm{H}), 1.05(\mathrm{~s}, 9 \mathrm{H}) ;{ }^{13} \mathrm{C}$ NMR $\left(125 \mathrm{MHz}, \mathrm{CDCl}_{3}\right) \delta 202.6,135.5,133.8,129.6$, 127.6, 63.3, 43.5, 31.8, 26.8, 19.2, 18.5; HRMS $\left(\mathrm{CI} / \mathrm{NH}_{3}\right) m / z$ calcd for $\mathrm{C}_{21} \mathrm{H}_{27} \mathrm{O}_{2} \mathrm{Si}(\mathrm{M}-\mathrm{H})^{+}$ 339.1780 , found 339.1780 .

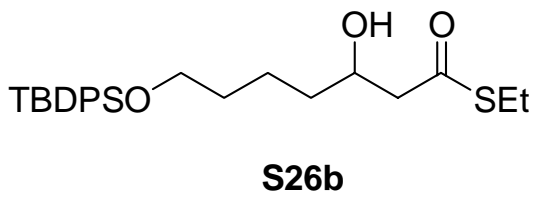

7-[(tert-butyldiphenylsilyl)oxy]-3-hydroxyheptanethioic acid S-ethyl ester (S26b): ${ }^{22}$ To a cooled $\left(0{ }^{\circ} \mathrm{C}\right)$ suspension of ytterbium(III) trifluoromethanesulfonate $(2.30 \mathrm{~g}, 0.371 \mathrm{mmol})$ in $125 \mathrm{~mL}$ of $\mathrm{CH}_{2} \mathrm{Cl}_{2}$ was added 5-[(tert-butyldiphenylsilyl)oxy]pentanal (S25) (12.63 g, 37.09 mmol) and 1-trimethylsilyloxy-1-ethylthioethene ${ }^{23}(7.96 \mathrm{~g}, 45.1 \mathrm{mmol})$. After stirring for $1 \mathrm{~h}$ at $0{ }^{\circ} \mathrm{C}$, the mixture was poured into $50 \mathrm{~mL}$ of a saturated aqueous solution of $\mathrm{NaHCO}_{3}$. The layers were separated, and the aqueous layer was extracted with $3 \times 10 \mathrm{~mL}$ of $\mathrm{CH}_{2} \mathrm{Cl}_{2}$. The combined organic extracts were washed with $50 \mathrm{~mL}$ of brine, dried over $\mathrm{Na}_{2} \mathrm{SO}_{4}$, filtered, and concentrated in vacuo to afford thioester $\mathbf{S 2 6 a}$. To prepare the desired thioester $\mathbf{S 2 6} \mathbf{b}$, a cooled $\left(0{ }^{\circ} \mathrm{C}\right)$ solution of S26a in $200 \mathrm{~mL}$ of THF and $50 \mathrm{~mL}$ of $1.0 \mathrm{M} \mathrm{HCl}$ was stirred for $1 \mathrm{~h}$ at $0{ }^{\circ} \mathrm{C}$. After $1 \mathrm{~h}$, the mixture was partitioned between $50 \mathrm{~mL}$ of $\mathrm{H}_{2} \mathrm{O}$ and $200 \mathrm{~mL}$ of $\mathrm{Et}_{2} \mathrm{O}$. The layers were separated, 
and the aqueous layer was extracted with $3 \times 10 \mathrm{~mL}$ of $\mathrm{Et}_{2} \mathrm{O}$. The combined organic extracts were washed with $2 \times 50 \mathrm{~mL}$ of a saturated aqueous solution of $\mathrm{NaHCO}_{3}$, then $100 \mathrm{~mL}$ of brine. The organic extracts were dried over anhydrous $\mathrm{Na}_{2} \mathrm{SO}_{4}$, filtered, and concentrated in vacuo to afford pure S26b as a pale yellow oil (14.50 g, 88\%):

S26a: $\mathrm{R}_{f}=0.60,10: 90 \mathrm{EtOAc} /$ hexanes; ${ }^{1} \mathrm{H}$ NMR $\left(500 \mathrm{MHz}, \mathrm{CDCl}_{3}\right) \delta 7.68(\mathrm{~d}, J=6.4$, 4H), $7.41(\mathrm{~m}, 6 \mathrm{H}), 4.15(\mathrm{~m}, 1 \mathrm{H}), 3.68(\mathrm{t}, J=6.2,2 \mathrm{H}), 2.89(\mathrm{q}, J=7.4,2 \mathrm{H}), 2.71(\mathrm{dd}, J=14.4$, 7.4, 1H), $2.62(\mathrm{dd}, J=14.4,5.0,1 \mathrm{H}), 1.58(\mathrm{~m}, 2 \mathrm{H}), 1.48(\mathrm{~m}, 3 \mathrm{H}), 1.39(\mathrm{~m}, 1 \mathrm{H}), 1.27(\mathrm{t}, J=7.4$, 3H), 1.07 (s, 9H), $0.12(\mathrm{~s}, 9 \mathrm{H}) ;{ }^{13} \mathrm{C}$ NMR $\left(125 \mathrm{MHz}, \mathrm{CDCl}_{3}\right) \delta$ 197.7, 135.5, 134.0, 129.5, 127.6, $69.7,63.7,52.1,37.4,32.5,26.9,23.3,21.8,19.2,14.7,0.2$.

S26b: $\mathrm{R}_{f}=0.46,20: 80 \mathrm{EtOAc} /$ hexanes; ${ }^{1} \mathrm{H}$ NMR $\left(500 \mathrm{MHz}, \mathrm{CDCl}_{3}\right) \delta 7.66(\mathrm{dd}, J=7.8$, $1.8,4 \mathrm{H}), 7.40(\mathrm{~m}, 6 \mathrm{H}), 4.02(\mathrm{~m}, 1 \mathrm{H}), 3.66(\mathrm{t}, J=6.3,2 \mathrm{H}), 2.89(\mathrm{q}, J=7.4,2 \mathrm{H}), 2.71(\mathrm{~d}, J=4.0$, 1H), $2.70(\mathrm{dd}, J=15.7,3.3,1 \mathrm{H}), 2.63(\mathrm{dd}, J=15.7,8.6,1 \mathrm{H}), 1.57(\mathrm{~m}, 2 \mathrm{H}), 1.49(\mathrm{~m}, 2 \mathrm{H}), 1.41$ $(\mathrm{m}, 2 \mathrm{H}), 1.26(\mathrm{t}, J=7.4,3 \mathrm{H}), 1.05(\mathrm{~s}, 9 \mathrm{H}) ;{ }^{13} \mathrm{C} \mathrm{NMR}\left(125 \mathrm{MHz}, \mathrm{CDCl}_{3}\right) \delta$ 199.6, 135.5, 134.0, 129.5, 127.6, 68.6, 63.6, 50.6, 36.2, 32.3, 26.8, 23.3, 21.7, 19.2, 14.6; IR (neat) 3457, 3070, 2931, 1684, 1428, $1112 \mathrm{~cm}^{-1}$; HRMS $\left(\mathrm{CI} / \mathrm{NH}_{3}\right) \mathrm{m} / z$ calcd for $\mathrm{C}_{25} \mathrm{H}_{37} \mathrm{O}_{3} \mathrm{SSi}(\mathrm{M}+\mathrm{H})^{+} 445.2232$, found 445.2229. Anal. Calcd for $\mathrm{C}_{25} \mathrm{H}_{36} \mathrm{O}_{3} \mathrm{SSi}$ : C, 67.52; H, 8.16. Found: C, 67.44; H, 8.17.

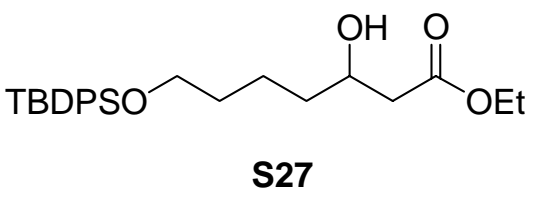

7-[(tert-butyldiphenylsilyl)oxy]-3-hydroxyheptanoic acid ethyl ester (S27): ${ }^{24}$ To a solution of $\beta$-hydroxy thioester S26b $(11.80 \mathrm{~g}, 26.53 \mathrm{mmol})$ in $250 \mathrm{~mL}$ of absolute ethanol (dried over activated $3 \AA$ molecular sieves) were added silver trifluoroacetate $(10.55 \mathrm{~g}, 47.75 \mathrm{mmol})$ and $\mathrm{N}, \mathrm{N}$-diisopropylethylamine $(11.6 \mathrm{~mL}, 66.3 \mathrm{mmol})$ dropwise by syringe. After $1 \mathrm{~h}$ of stirring at 
ambient temperature, the reaction mixture was concentrated in vacuo and was partitioned between $200 \mathrm{~mL}$ of $\mathrm{Et}_{2} \mathrm{O}$ and $100 \mathrm{~mL}$ of water. The layers were separated, and the organic layer was washed with $2 \times 100 \mathrm{~mL}$ of water, $2 \times 50 \mathrm{~mL}$ of a saturated aqueous solution of $\mathrm{CuSO}_{4}$, and $1 \times 100 \mathrm{~mL}$ of brine, then was dried over $\mathrm{MgSO}_{4}$, filtered, and concentrated in vacuo to obtain a brown liquid. Purification by flash column chromatography on silica gel (15:85 to 25:75 EtOAc/hexanes) afforded the product as a colorless liquid (9.6 g, 84\%): $\mathrm{R}_{f}=0.33,20: 80$ EtOAc/hexanes; ${ }^{1} \mathrm{H}$ NMR $\left(500 \mathrm{MHz}, \mathrm{CDCl}_{3}\right) \delta 7.66(\mathrm{dd}, J=6.5,0.9,4 \mathrm{H}), 7.38(\mathrm{~m}, 6 \mathrm{H}), 4.16(\mathrm{q}$, $J=7.1,2 \mathrm{H}), 3.97(\mathrm{~m}, 1 \mathrm{H}), 3.67(\mathrm{t}, J=6.3,2 \mathrm{H}), 2.81(\mathrm{br} \mathrm{s}, 1 \mathrm{H}), 2.47(\mathrm{dd}, J=16.4,3.0,1 \mathrm{H}), 2.37$ $(\mathrm{dd}, J=16.4,9.0,1 \mathrm{H}), 1.58(\mathrm{~m}, 2 \mathrm{H}), 1.50(\mathrm{~m}, 2 \mathrm{H}), 1.42(\mathrm{~m}, 2 \mathrm{H}), 1.27(\mathrm{t}, J=7.1,3 \mathrm{H}), 1.05(\mathrm{~s}$, 9H); ${ }^{13} \mathrm{C}$ NMR $\left(125 \mathrm{MHz}, \mathrm{CDCl}_{3}\right) \delta 173.0,135.5,134.0,129.5,127.6,67.9,63.7,60.6,41.2$, $36.2,32.3,26.9,21.7,19.2,14.2$; IR (thin film) $3583,2933,2860,1720,1428,1111 \mathrm{~cm}^{-1}$; HRMS (TOF MS ES+) $m / z$ calcd for $\mathrm{C}_{25} \mathrm{H}_{36} \mathrm{O}_{4} \mathrm{SiNa}(\mathrm{M}+\mathrm{Na})^{+} 451.2281$, found 451.2273. Anal. Calcd for $\mathrm{C}_{25} \mathrm{H}_{36} \mathrm{O}_{3} \mathrm{SSi}$ : C, 70.05; H, 8.47. Found: C, 69.86; H, 8.51.

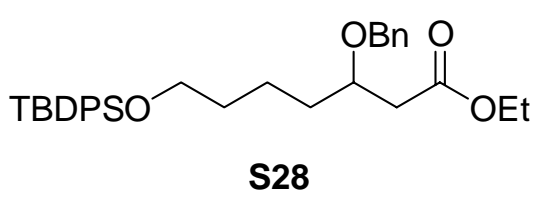

3-Benzyloxy-7-[(tert-butyldiphenylsilyl)oxy $]$ heptanoic acid ethyl ester (S28): ${ }^{25}$ To a stirred solution of $\beta$-hydroxy ester S27 (6.25 g, $14.6 \mathrm{mmol}$ ) and benzyl 2,2,2-trichloroacetimidate (3.25 $\mathrm{mL}, 17.5 \mathrm{mmol}$ ) in $20 \mathrm{~mL}$ of cyclohexane and $10 \mathrm{~mL}$ of $\mathrm{CH}_{2} \mathrm{Cl}_{2}$ at ambient temperature was added trifluoromethanesulfonic acid $(0.20 \mathrm{~mL}, 2.3 \mathrm{mmol})$ dropwise by syringe. A flaky white precipitate (trichloroacetamide) formed immediately. After $15 \mathrm{~min}$, the mixture was vacuumfiltered through a sintered-glass funnel. The reaction flask was rinsed with $25 \mathrm{~mL}$ of 9:1 (v/v) hexanes:EtOAc, and the rinsing solution was used to wash the trichloroacetamide crystals. The 
filtrate was successively washed with $50 \mathrm{~mL}$ portions of saturated aqueous $\mathrm{NaHCO}_{3}$ and water, then was dried over anhydrous $\mathrm{MgSO}_{4}$, filtered, and concentrated in vacuo. Purification by flash column chromatography on silica gel (5:95 to $25: 75 \mathrm{EtOAc/hexanes)} \mathrm{afforded} 0.532 \mathrm{~g}$ of $\mathbf{S 2 7}$ and the desired product as a colorless oil $(5.30 \mathrm{~g}, 70 \%): \mathrm{R}_{f}=0.60,20: 80 \mathrm{EtOAc} / \mathrm{hexanes} ;{ }^{1} \mathrm{H}$ $\operatorname{NMR}\left(500 \mathrm{MHz}, \mathrm{CDCl}_{3}\right) \delta 7.66(\mathrm{~m}, 4 \mathrm{H}), 7.38(\mathrm{~m}, 6 \mathrm{H}), 7.29(\mathrm{~m}, 5 \mathrm{H}), 4.54(\mathrm{~d}, J=11.3,1 \mathrm{H})$, $4.51(\mathrm{~d}, J=11.3,1 \mathrm{H}), 4.13(\mathrm{q}, J=7.1,1 \mathrm{H}), 4.12(\mathrm{q}, J=7.1,1 \mathrm{H}), 3.88$ (dddd, $J=7.3,6.8,5.3$, $5.1,1 \mathrm{H}), 3.65(\mathrm{t}, J=6.2,2 \mathrm{H}), 2.59(\mathrm{dd}, J=15.1,7.3,1 \mathrm{H}), 2.45(\mathrm{dd}, J=15.1,5.3,1 \mathrm{H}), 1.64--$ $1.40(\mathrm{~m}, 6 \mathrm{H}), 1.24(\mathrm{t}, J=7.1,3 \mathrm{H}), 1.05(\mathrm{~s}, 9 \mathrm{H}),{ }^{13} \mathrm{C} \mathrm{NMR}\left(125 \mathrm{MHz}, \mathrm{CDCl}_{3}\right) \delta 171.8,138.5$, $135.5,134.0,129.5,128.3,127.7,127.6,127.5,76.1,71.6,63.7,60.4,40.0,34.2,32.5,26.9$, 21.6, 19.2, 14.2; IR (neat) 3069, 2931, 2857, 1735, 1428, $1110 \mathrm{~cm}^{-1} ; \mathrm{HRMS}\left(\mathrm{CI} / \mathrm{NH}_{3}\right) \mathrm{m} / z$ calcd for $\mathrm{C}_{32} \mathrm{H}_{43} \mathrm{O}_{4} \mathrm{Si}(\mathrm{M}+\mathrm{H})^{+}$519.2930, found 519.2920. Anal. Calcd for $\mathrm{C}_{32} \mathrm{H}_{42} \mathrm{O}_{4} \mathrm{Si}$ : C, 74.09; H, 8.16. Found: C, $74.34 ; \mathrm{H}, 8.06$.

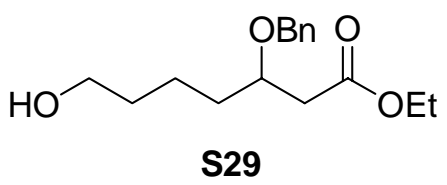

3-Benzyloxy-7-hydroxyheptanoic acid ethyl ester (S29): ${ }^{26}$ To a solution of ester $\mathbf{S 2 8}(0.667 \mathrm{~g}$, $1.29 \mathrm{mmol}$ ) in $13 \mathrm{~mL}$ of tetrahydrofuran in a small polypropylene bottle was added an excess of $(\mathrm{HF})_{\mathrm{x}}$.pyridine $(1 \mathrm{~mL}$ of a $65-70 \%$ solution $)$. The solution was stirred at ambient temperature for $12 \mathrm{~h}$, and then the acid was quenched by adding $5 \mathrm{~mL}$ of a saturated aqueous solution of $\mathrm{NaHCO}_{3}$. The mixture was diluted with $10 \mathrm{~mL}$ of $\mathrm{Et}_{2} \mathrm{O}$, the layers were separated, and the aqueous layer was extracted with $3 \times 5 \mathrm{~mL}^{\text {of }} \mathrm{Et}_{2} \mathrm{O}$. The combined organic extracts were washed with $2 \times 5 \mathrm{~mL}$ of $1 \mathrm{M} \mathrm{NaHSO}_{4}$ and $1 \times 10 \mathrm{~mL}$ of brine, dried over $\mathrm{MgSO}_{4}$, filtered, and concentrated in vacuo. Purification by flash column chromatography on silica gel (20:80 to 
70:30 EtOAc/hexanes) afforded the product as a colorless oil $(0.33 \mathrm{~g}, 92 \%): \mathrm{R}_{f}=0.42,50: 50$ EtOAc/hexanes; ${ }^{1} \mathrm{H}$ NMR $\left(500 \mathrm{MHz}, \mathrm{CDCl}_{3}\right) \delta 7.30(\mathrm{~m}, 5 \mathrm{H}), 4.56(\mathrm{~d}, J=11.4,1 \mathrm{H}), 4.52(\mathrm{~d}, J=$ $11.4,1 \mathrm{H}), 4.14(\mathrm{q}, J=7.1,1 \mathrm{H}), 4.13(\mathrm{q}, J=7.1,1 \mathrm{H}), 3.88(\mathrm{~m}, 1 \mathrm{H}), 3.63(\mathrm{t}, J=6.0,2 \mathrm{H}), 2.63$ $(\mathrm{ddd}, J=15.0,7.1,1.0,1 \mathrm{H}), 2.47(\mathrm{ddd}, J=15.0,5.9,0.9,1 \mathrm{H}), 1.68-1.37(\mathrm{~m}, 7 \mathrm{H}), 1.25(\mathrm{t}, J=$ $7.1,3 \mathrm{H}) ;{ }^{13} \mathrm{C} \mathrm{NMR}\left(125 \mathrm{MHz}, \mathrm{CDCl}_{3}\right) \delta 171.7,138.4,128.3,127.7,127.5,75.9,71.5,62.6$, 60.4, 39.8, 34.1, 32.5, 21.3, 14.1; IR (neat) 3448 (br), 2939, 2868, 1734, 1370, $1246 \mathrm{~cm}^{-1}$; HRMS (TOF MS ES+) $m / z$ calcd for $\mathrm{C}_{16} \mathrm{H}_{25} \mathrm{O}_{4}(\mathrm{M}+\mathrm{H})^{+} 281.1753$, found 281.1750. Anal. Calcd for $\mathrm{C}_{16} \mathrm{H}_{24} \mathrm{O}_{4}:$ C, 68.55; H, 8.63. Found: C, 68.05; H, 8.70.

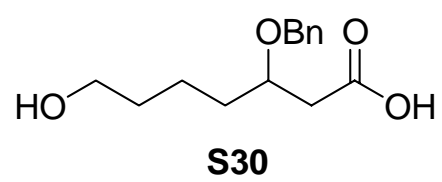

3-Benzyloxy-7-hydroxyheptanoic acid $(\mathbf{S 3 0}):^{27}$ To a cooled $\left(0{ }^{\circ} \mathrm{C}\right)$ solution of ester $\mathbf{S 2 9}(2.33$ $\mathrm{g}, 8.31 \mathrm{mmol})$ in $32 \mathrm{~mL}$ of $\mathrm{MeOH} / \mathrm{H}_{2} \mathrm{O}(3: 1 \mathrm{v} / \mathrm{v})$ was added $\mathrm{LiOH} \cdot \mathrm{H}_{2} \mathrm{O}(0.891 \mathrm{~g}$ of hydrate, $56 \%$ $\mathrm{LiOH}, 11.9 \mathrm{mmol}$ of $\mathrm{LiOH}$ ), then the solution was warmed to ambient temperature. After $4 \mathrm{~h}$, the reaction mixture was acidified to below pH 2 using $40 \mathrm{~mL}$ of $1.0 \mathrm{M} \mathrm{HCl}$, then $50 \mathrm{~mL}$ of EtOAc and $25 \mathrm{~mL}$ of brine were added to facilitate separation of the layers. The aqueous portion was extracted with $10 \times 10 \mathrm{~mL}$ of EtOAc, then the combined organic extracts were washed with $50 \mathrm{~mL}$ of brine, dried over anhydrous $\mathrm{MgSO}_{4}$, filtered, and concentrated in vacuo to afford the pure product as a colorless syrup $(1.825 \mathrm{~g}, 87 \%):{ }^{1} \mathrm{H} \mathrm{NMR}\left(500 \mathrm{MHz}, \mathrm{CDCl}_{3}\right) \delta 7.30(\mathrm{~m}, 5 \mathrm{H})$, $4.59(\mathrm{~d}, J=11.4,1 \mathrm{H}), 4.55(\mathrm{~d}, J=11.4,1 \mathrm{H}), 3.88(\mathrm{~m}, 1 \mathrm{H}), 3.63(\mathrm{t}, J=6.3,2 \mathrm{H}), 2.65(\mathrm{dd}, J=$ $15.4,5.7,1 \mathrm{H}), 2.55(\mathrm{dd}, J=15.4,5.7,1 \mathrm{H}), 1.71-1.45(\mathrm{~m}, 6 \mathrm{H}) ;{ }^{13} \mathrm{C} \mathrm{NMR}\left(125 \mathrm{MHz}, \mathrm{CDCl}_{3}\right) \delta$ 175.7, 138.0, 128.4, 127.9, 127.8, 75.6, 71.6, 62.6, 39.2, 33.9, 32.4, 21.3; IR (neat) 3400 (br), 3030, 2867, 1713, 1454, $1279 \mathrm{~cm}^{-1}$; HRMS $\left(\mathrm{CI} / \mathrm{NH}_{3}\right) \mathrm{m} / z$ calcd for $\mathrm{C}_{14} \mathrm{H}_{21} \mathrm{O}_{4}(\mathrm{M}+\mathrm{H})^{+}$ 
253.1440, found 253.1437. Anal. Calcd for $\mathrm{C}_{14} \mathrm{H}_{20} \mathrm{O}_{4}$ : C, 66.65; H, 7.99. Found: C, 66.88; H, 8.01 .

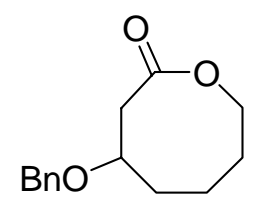

S31

4-(Benzyloxy)oxacyclooctan-2-one (S31): ${ }^{12}$ To a solution of $\omega$-hydroxy acid S30 $(0.500 \mathrm{~g}$, $1.98 \mathrm{mmol}$ ) in $12 \mathrm{~mL}$ of anhydrous tetrahydrofuran containing powdered, activated $4 \AA$ molecular sieves (ca. $0.05 \mathrm{~g}$ ) was added $\mathrm{Et}_{3} \mathrm{~N}(0.41 \mathrm{~mL}, 2.98 \mathrm{mmol})$, and the mixture was stirred at ambient temperature for $15 \mathrm{~min}$. Then, a solution of 2,4,6-trichlorobenzoyl chloride $(0.34 \mathrm{~mL}$, $2.18 \mathrm{mmol}$ ) in $9 \mathrm{~mL}$ of tetrahydrofuran was added by cannula, and the mixture was stirred for 3 h. This solution was diluted to $100 \mathrm{~mL}$ with toluene, then was added by syringe pump (in two 50 $\mathrm{mL}$ portions) over approximately $5 \mathrm{~h}$ to a refluxing solution of 4 -( $N, N$-dimethylamino)pyridine (3.64 g, $29.8 \mathrm{mmol}$ ) in $121 \mathrm{~mL}$ of toluene. After an additional $12 \mathrm{~h}$ of heating at reflux, the solution was cooled to ambient temperature, and $50 \mathrm{~mL}$ of $\mathrm{pH} 7.00$ buffer was added. The layers were separated, and the aqueous portion was extracted with $3 \times 10 \mathrm{~mL}$ of $\mathrm{Et}_{2} \mathrm{O}$. The combined organic extracts were washed with an ice-cold saturated aqueous solution of $\mathrm{CuSO}_{4}(2 \times 10 \mathrm{~mL})$, $20 \mathrm{~mL}$ of $\mathrm{H}_{2} \mathrm{O}, 10 \mathrm{~mL}$ of saturated aqueous $\mathrm{NaHCO}_{3}$, and $20 \mathrm{~mL}$ of brine, then they were dried over anhydrous $\mathrm{MgSO}_{4}$, filtered, and concentrated in vacuo. Purification by flash column chromatography on deactivated silica gel (20:80 to 40:60 EtOAc/hexanes) afforded the lactone S31 as a yellow oil $(0.367 \mathrm{~g}, 79 \%)$ and the lactone dimer $\left(0.044 \mathrm{~g}, 10 \%, \mathrm{R}_{f}=0.50,30: 70\right.$ EtOAc/hexanes): $\mathrm{R}_{f}=0.25,30: 70$ EtOAc/hexanes; ${ }^{1} \mathrm{H} \mathrm{NMR}\left(500 \mathrm{MHz}, \mathrm{CDCl}_{3}\right) \delta 7.30(\mathrm{~m}, 5 \mathrm{H})$, $4.60(\mathrm{~d}, J=11.8,1 \mathrm{H}), 4.54(\mathrm{~d}, J=11.8,1 \mathrm{H}), 4.39(\mathrm{ddd}, J=12.7,8.1,3.5,1 \mathrm{H}), 4.33(\mathrm{ddd}, J=$ $12.7,5.7,4.3,1 \mathrm{H}), 3.81(\mathrm{dddd}, J=9.2,7.3,4.7,3.1,1 \mathrm{H}), 2.86(\mathrm{dd}, J=12.1,4.8,1 \mathrm{H}), 2.80(\mathrm{dd}, J$ 
$=12.1,9.2,1 \mathrm{H}), 1.89-1.77(\mathrm{~m}, 5 \mathrm{H}), 1.38(\mathrm{~m}, 1 \mathrm{H}) ;{ }^{13} \mathrm{C} \mathrm{NMR}\left(125 \mathrm{MHz}, \mathrm{CDCl}_{3}\right) \delta$ 172.6, 138.0, 128.4, 127.7, 127.6, 76.9, 70.7, 68.3, 36.2, 31.8, 30.7, 18.8; IR (neat) 2936, 2869, 1728, 1454, 1363, $1226 \mathrm{~cm}^{-1}$; HRMS (EI/GCMS) $m / z$ calcd for $\mathrm{C}_{14} \mathrm{H}_{19} \mathrm{O}_{4}\left(\mathrm{M}^{+}\right)$234.1256, found 234.1252. Anal. Calcd for $\mathrm{C}_{14} \mathrm{H}_{18} \mathrm{O}_{4}$ : C, 71.77; H, 7.74. Found: C, 71.81; H, 7.49.

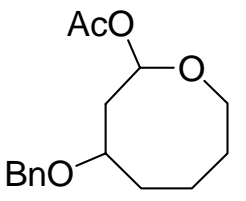

$15 b$

Acetic acid 4-(benzyloxy)oxocan-2-yl ester $(\mathbf{1 5 b}):^{4}$ To a cooled $\left(-78^{\circ} \mathrm{C}\right)$ solution of lactone S31 $(0.071 \mathrm{~g}, 0.030 \mathrm{mmol})$ in $2 \mathrm{~mL}$ of $\mathrm{CH}_{2} \mathrm{Cl}_{2}$ was added ${ }^{i} \mathrm{Bu}_{2} \mathrm{AlH}(1.5 \mathrm{M}$ in toluene, $0.41 \mathrm{~mL}$, $0.61 \mathrm{mmol}$ ) dropwise by syringe. After $45 \mathrm{~min}$, the reaction mixture was treated sequentially with pyridine $(0.074 \mathrm{~mL}, 0.91 \mathrm{mmol})$ dropwise by syringe, neat 4-( $N, N$-dimethylamino)pyridine ( $0.074 \mathrm{~g}, 0.61 \mathrm{mmol})$, and $\mathrm{Ac}_{2} \mathrm{O}(0.172 \mathrm{~mL}, 1.82 \mathrm{mmol})$ dropwise by syringe. The mixture was stirred at $-78{ }^{\circ} \mathrm{C}$ for $14 \mathrm{~h}$, warmed to $-20^{\circ} \mathrm{C}$, and stirred for an additional $30 \mathrm{~min}$. After $30 \mathrm{~min}$, a mixture of saturated aqueous $\mathrm{NH}_{4} \mathrm{Cl}(5 \mathrm{~mL})$ and saturated aqueous sodium potassium tartrate $(5 \mathrm{~mL})$ were added. The resulting mixture was then warmed to ambient temperature, and stirred vigorously for $1 \mathrm{~h}$ before $5 \mathrm{~mL}$ of brine was added. After the layers were separated, the aqueous portion was extracted with $5 \times 5 \mathrm{~mL}$ of $\mathrm{CH}_{2} \mathrm{Cl}_{2}$. The combined organic extracts were washed with ice-cold 1.0 $\mathrm{M} \mathrm{NaHSO}_{4}(2 \times 5 \mathrm{~mL})$, saturated $\mathrm{NaHCO}_{3}(3 \times 5 \mathrm{~mL})$, and brine $(10 \mathrm{~mL})$, and then were dried over anhydrous $\mathrm{MgSO}_{4}$, filtered, and concentrated in vacuo. Purification by flash column chromatography on deactivated silica gel (10:90 to 40:60 EtOAc/hexanes) afforded the product as an approximate 55:45 mixture of diastereomers $(0.049 \mathrm{~g}, 58 \%): \mathrm{R}_{f}=0.46,20: 80$ EtOAc/hexanes; GC $t_{\mathrm{R}}$ (major) $6.62 \mathrm{~min}, t_{\mathrm{R}}$ (minor) $6.90 \mathrm{~min}\left(150{ }^{\circ} \mathrm{C}\right.$ for $1 \mathrm{~min}, 10 \% \mathrm{~min}$, to 250 
$\left.{ }^{\circ} \mathrm{C}\right):{ }^{1} \mathrm{H}$ NMR $\left(500 \mathrm{MHz}, \mathrm{CDCl}_{3}\right) \delta 7.30(\mathrm{~m}, 9 \mathrm{H}), 6.11(\mathrm{dd}, J=10.0,2.6,0.8 \mathrm{H}), 5.87(\mathrm{dd}, J=$ $10.9,2.4,1 \mathrm{H}), 4.54(\mathrm{dd}, J=11.9,1.8 \mathrm{H}), 4.48(\mathrm{dd}, J=11.9,1.8 \mathrm{H}), 3.96(\mathrm{ddd}, J=12.4,9.6,2.6$, 1H), 3.94 (ddd, $J=12.3,8.8,3.4,0.8 \mathrm{H}$ ), 3.85 (ddd, $J=12.3,5.8,4.0,0.8 \mathrm{H}$ ), 3.77 (dt, $J=12.4$, 4.9, 1H), 3.71 (dddd, $J=8.6,5.6,4.7,3.3,0.8 \mathrm{H}), 3.61(\mathrm{dddd}, J=10.9,5.3,4.0,3.4,1 \mathrm{H}), 2.19$ $(\mathrm{dt}, J=14.0,10.9,1 \mathrm{H}), 2.16(\mathrm{ddd}, J=14.7,10.0,3.3,0.8 \mathrm{H}), 2.07(\mathrm{ddd}, J=14.0,4.0,2.4,1 \mathrm{H})$, $2.06(\mathrm{~s}, 3 \mathrm{H}), 2.05(\mathrm{~s}, 2.4 \mathrm{H}), 1.99(\mathrm{ddd}, J=14.7,5.6,2.6,0.8 \mathrm{H}), 1.97-1.91(\mathrm{~m}, 3.4 \mathrm{H}), 1.84-1.72$ (m, 2.6H), 1.69-1.52 (m, 3.8H), $\left.1.41(\mathrm{~m}, 1 \mathrm{H}) ;{ }^{13} \mathrm{C} \mathrm{NMR} \mathrm{(125} \mathrm{MHz,} \mathrm{CDCl}_{3}\right) \delta$ 170.2, 170.1, $138.7,138.6,128.34,128.29,127.48,127.45,127.39,127.38,94.9,94.7,76.1,74.9,70.3,70.1$, $68.2,66.7,36.1,35.5,31.8,31.2,30.5,29.7,21.31,21.25,21.2,20.8$; IR (thin film) 2934,2861 , 1744, 1364, 1240, $1013 \mathrm{~cm}^{-1}$; HRMS (EI+) $\mathrm{m} / z$ calcd for $\mathrm{C}_{14} \mathrm{H}_{19} \mathrm{O}_{2}\left(\mathrm{M}-\mathrm{C}_{2} \mathrm{H}_{3} \mathrm{O}_{2}\right)^{+} 219.1385$, found 219.1377. Anal. Calcd for $\mathrm{C}_{14} \mathrm{H}_{18} \mathrm{O}_{4}$ : C, 69.04; H, 7.97. Found: C, 69.16; H, 7.92.

\section{Nucleophilic Substitution Reactions}

Standard Nucleophilic Substitution Procedure: Trimethylsilylcyanide (4.0 equiv, distilled and stored over activated $4 \AA$ molecular sieves in a Schlenk flask) was added to a solution of acetate in $\mathrm{CH}_{2} \mathrm{Cl}_{2}(0.1 \mathrm{M})$. The mixture was cooled to $-78{ }^{\circ} \mathrm{C}$ and treated with the Lewis acid (1.2 equiv) dropwise by syringe. The solution was slowly warmed to ambient temperature over 1 $\mathrm{h}$, then was quenched with a 1:1:1 mixture of $\mathrm{Et}_{3} \mathrm{~N}: \mathrm{MeOH}: \mathrm{CH}_{2} \mathrm{Cl}_{2}(1 \mathrm{~mL}$ per mmol of acetate). The mixture was diluted with EtOAc (20 mL per mmol of acetate), washed with one portion (one portion equals $20 \mathrm{~mL}$ per mmol of acetate for each wash) of water and one portion of a saturated aqueous solution of $\mathrm{NaHCO}_{3}$, dried over anhydrous $\mathrm{MgSO}_{4}$, filtered through a plug of silica gel, and concentrated in vacuo. When possible, the unpurified product ratios were determined using GC and confirmed using GCMS and single-scan ${ }^{1} \mathrm{H}$ NMR spectroscopy. When nucleophilic 
substitution products co-eluted even under optimized GC conditions, ${ }^{1} \mathrm{H}$ NMR spectroscopy was used to report product ratios. The reported yields are of purified material.

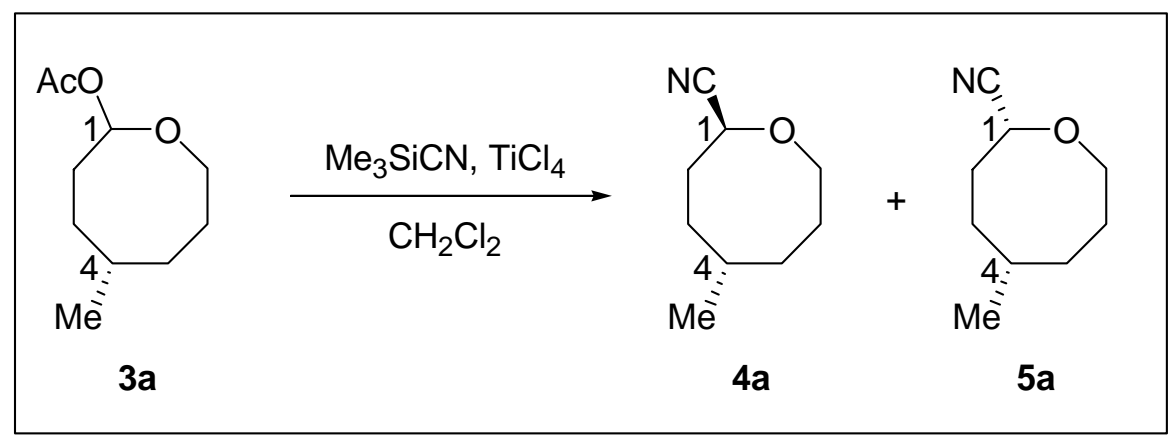

5-Methyloxocane-2-carbonitrile (4a and 5a): Under standard nucleophilic substitution conditions using $\mathrm{TiCl}_{4}$ as the Lewis acid, acetate $3 \mathbf{a}(0.186 \mathrm{~g}, 1.00 \mathrm{mmol})$ afforded the product as an inseparable 58:42 mixture of diastereomers. The resulting oil was purified by flash column chromatography on silica gel (10:90 to $20: 80 \mathrm{Et}_{2} \mathrm{O} /$ hexanes) to provide the product as a volatile pale yellow oil $(0.150 \mathrm{~g}, 98 \%): \mathrm{R}_{f}=0.60,20: 80$ EtOAc/hexanes; $\mathrm{GC} t_{\mathrm{R}}$ (major) $7.73 \mathrm{~min}$, $t_{\mathrm{R}}$ (minor) $7.82 \min \left(50{ }^{\circ} \mathrm{C}\right.$ for $1 \mathrm{~min}, 10 \% \mathrm{~min}$, to $\left.150{ }^{\circ} \mathrm{C}\right):{ }^{1} \mathrm{H}$ NMR $\left(500 \mathrm{MHz}, \mathrm{CDCl}_{3}\right) \delta 4.49$ $(\mathrm{dd}, J=10.9,3.8,1 \mathrm{H}), 4.40(\mathrm{dd}, J=10.3,4.1,1 \mathrm{H}), 3.90(\mathrm{ddd}, J=12.3,6.9,4.4,1 \mathrm{H}), 3.82(\mathrm{dt}, J$ $=12.3,4.2,1 \mathrm{H}), 3.76(\mathrm{ddd}, J=12.3,8.3,6.1,1 \mathrm{H}), 3.66(\mathrm{ddd}, J=12.3,7.6,4.6,1 \mathrm{H}), 2.21(\mathrm{dtd}, J$ $=15.3,10.9,3.3,1 \mathrm{H}), 2.03(\mathrm{dddd}, J=14.8,8.6,4.1,2.6,1 \mathrm{H}), 1.94(\mathrm{dddd}, J=14.8,10.2,9.4$, 2.8, 1H), $1.80(\mathrm{~m}, 5 \mathrm{H}), 1.67(\mathrm{~m}, 5 \mathrm{H}), 1.56(\mathrm{dtd}, J=14.7,4.6,2.1,1 \mathrm{H}), 1.37(\mathrm{~m}, 4 \mathrm{H}), 0.93(\mathrm{~d}, J=$ 6.8, 3H), $0.92(\mathrm{~d}, J=6.9,3 \mathrm{H}) ;{ }^{13} \mathrm{C}$ NMR $\left(125 \mathrm{MHz}, \mathrm{CDCl}_{3}\right) \delta 119.1,118.8,69.3,67.7,67.5$, $67.3,33.4,32.7,32.3,32.0,31.8,31.6,29.3,28.5,26.9,24.7,24.6$; IR (neat) 2952, 2868, 2254 , 1456, 1365, $1242 \mathrm{~cm}^{-1}$; HRMS (EI/GCMS) $m / z$ calcd for $\mathrm{C}_{9} \mathrm{H}_{14} \mathrm{NO}(\mathrm{M}-\mathrm{H})^{+} 152.1075$, found 152.1073. Anal. Calcd for $\mathrm{C}_{9} \mathrm{H}_{15} \mathrm{NO}$ : C, 70.55; H, 9.87; N, 9.14. Found: $\mathrm{C}, 70.31 ; \mathrm{H}, 9.92 ; \mathrm{N}$, 9.03. 


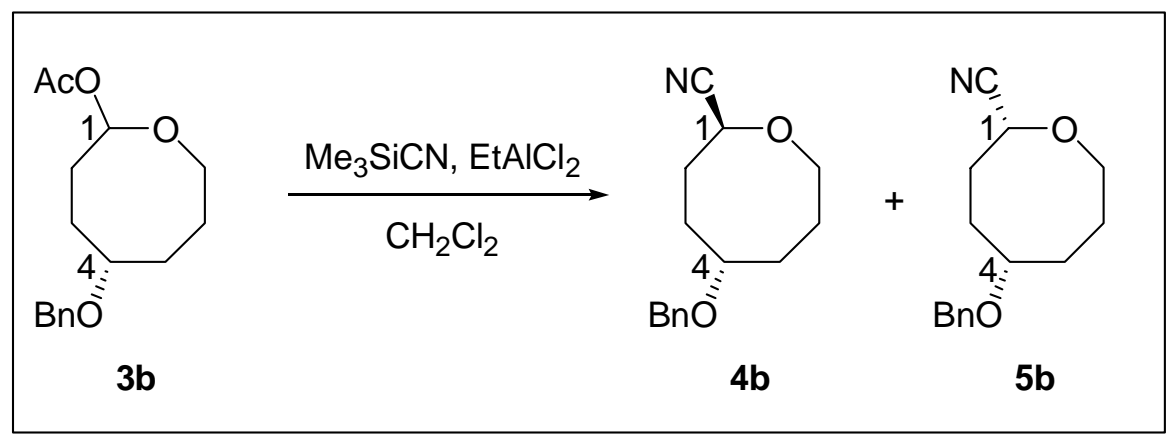

5-(Benzyloxy)oxocane-2-carbonitrile (4b and 5b): Under standard nucleophilic substitution conditions using $\mathrm{EtAlCl}_{2}$ as the Lewis acid, acetate $\mathbf{3 b}(0.400 \mathrm{~g}, 1.44 \mathrm{mmol})$ afforded the product as a separable 96:4 trans:cis mixture of diastereomers $\mathbf{4 b}$ and $\mathbf{5 b}$. This mixture was added to a separatory funnel containing $20 \mathrm{~mL}$ of $\mathrm{H}_{2} \mathrm{O}$, and the layers were separated. The aqueous layer was extracted with EtOAc $(4 \times 10 \mathrm{~mL})$, and the combined organic extracts were washed with brine (20 mL), dried over anhydrous $\mathrm{MgSO}_{4}$, filtered, and concentrated in vacuo. The resulting oil was purified by flash column chromatography on silica gel (10:90 to 20:80 EtOAc/hexanes) to provide $\mathbf{4 b}(0.330 \mathrm{~g}, 93 \%)$ and $\mathbf{5 b}(0.016 \mathrm{~g}, 5 \%)$ as colorless oils:

1,4-trans isomer (4b): $\mathrm{R}_{f}=0.30,20: 80 \mathrm{EtOAc} /$ hexanes; $\mathrm{GC} t_{\mathrm{R}} 7.60 \min \left(150{ }^{\circ} \mathrm{C}\right.$ for 1 $\min , 10 \%$ min, to $\left.270{ }^{\circ} \mathrm{C}\right) ;{ }^{1} \mathrm{H}$ NMR $\left(500 \mathrm{MHz}, \mathrm{C}_{6} \mathrm{D}_{6}\right) \delta$ 7.35-7.25 (m, 5H), $4.50(\mathrm{~s}, 2 \mathrm{H}), 4.32$ $(\mathrm{dd}, J=9.1,3.8,1 \mathrm{H}), 3.83(\mathrm{ddd}, J=12.3,8.8,4.2,1 \mathrm{H}), 3.79$ (dddd, $J=8.8,8.5,3.8,2.4,1 \mathrm{H})$, 3.61 (ddd, $J=12.3,5.5,4.5,1 \mathrm{H}), 2.13$ (dddd, $J=15.0,8.2,3.4,2.4,1 \mathrm{H}$ ), 2.06 (ddt, $J=15.0,8.5$, 2.1, 1H), $1.98(\mathrm{ddt}, J=13.4,10.1,3.2,1 \mathrm{H}), 1.91(\mathrm{ddd}, J=14.4,9.4,2.7,1 \mathrm{H}), 1.87(\mathrm{~m}, 1 \mathrm{H}), 1.81$ (dddd, $J=14.4,10.8,8.4,2.5,1 \mathrm{H}), 1.73(\mathrm{dtd}, J=13.9,8.6,2.0,1 \mathrm{H}), 1.61(\mathrm{~m}, 1 \mathrm{H}),{ }^{13} \mathrm{C}$ NMR $\left(125 \mathrm{MHz}, \mathrm{CDCl}_{3}\right) \delta 138.6,128.3,128.5,127.4,118.7,77.6,70.5,70.0,66.7,31.3,30.3,29.4$, 24.5; IR (thin film) 2940, 2865, 2359, 1454, 1366, $1101 \mathrm{~cm}^{-1}$ (obtained on a mixture of $\mathbf{4 b}$ and 5b); HRMS (CI/NH$)_{3} m / z$ calcd for $\mathrm{C}_{15} \mathrm{H}_{18} \mathrm{NO}_{2}(\mathrm{M}-\mathrm{H})^{+} 244.1338$, found 244.1333 (obtained 
on a mixture of $\mathbf{4 b}$ and $\mathbf{5 b}$ ). Anal. Calcd for $\mathrm{C}_{15} \mathrm{H}_{19} \mathrm{NO}_{2}$ : C, 73.44; H, 7.81; N, 5.71. Found: $\mathrm{C}$, 73.44; H, 7.93; N, 5.82 (obtained on a mixture of $\mathbf{4 b}$ and $\mathbf{5 b}$ ).

1,4-cis isomer (5b): $\mathrm{R}_{f}=0.43,20: 80 \mathrm{EtOAc} /$ hexanes; $\mathrm{GC} t_{\mathrm{R}} 7.47 \mathrm{~min}\left(150{ }^{\circ} \mathrm{C}\right.$ for $1 \mathrm{~min}$, $10 \% \mathrm{~min}$, to $\left.270{ }^{\circ} \mathrm{C}\right) ;{ }^{1} \mathrm{H}$ NMR $\left(500 \mathrm{MHz}, \mathrm{C}_{6} \mathrm{D}_{6}\right) \delta 7.26(\mathrm{~d}, J=7.4,2 \mathrm{H}), 7.19(\mathrm{t}, J=7.4,2 \mathrm{H})$, $7.10(\mathrm{t}, J=7.4,1 \mathrm{H}), 4.23(\mathrm{~d}, J=12.0,1 \mathrm{H}), 4.16(\mathrm{~d}, J=12.0,1 \mathrm{H}), 3.67(\mathrm{dd}, J=12.0,3.7,1 \mathrm{H})$, $3.39(\mathrm{tt}, J=7.5,6.6,1 \mathrm{H}), 3.38(\mathrm{dt}, J=12.8,4.7,1 \mathrm{H}), 3.27(\mathrm{ddd}, J=12.8,9.4,4.0,1 \mathrm{H}), 1.77$ (dddd, $J=15.0,12.0,9.7,5.2,1 \mathrm{H}), 1.54$ (dt, $J=14.7,4.3,1 \mathrm{H}), 1.44-1.39(\mathrm{~m}, 2 \mathrm{H}), 1.35$ (ddd, $J$ $=14.7,7.7,2.9,1 \mathrm{H}), 1.28-1.17(\mathrm{~m}, 2 \mathrm{H}), 1.01(\mathrm{dddd}, J=13.4,7.1,4.0,3.6,1 \mathrm{H}) ;{ }^{13} \mathrm{C} \mathrm{NMR}(125$ $\left.\mathrm{MHz}, \mathrm{C}_{6} \mathrm{D}_{6}\right) \delta 139.6,128.5,127.6,127.5,118.6,77.4,70.2,67.1,66.1,30.7,30.4,27.2,26.9$.

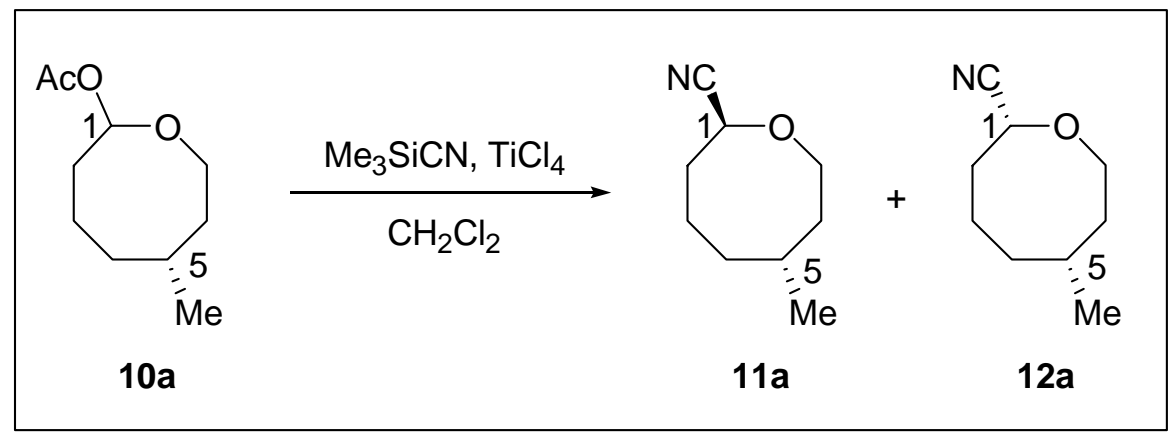

6-Methyloxocane-2-carbonitrile (11a and 12a): Under standard nucleophilic substitution conditions using $\mathrm{TiCl}_{4}$ as the Lewis acid, acetate 10a $(0.126 \mathrm{~g}, 0.677 \mathrm{mmol})$ afforded the product as an inseparable 52:48 mixture of diastereomers. The resulting oil was purified by flash column chromatography on silica gel $\left(0: 100\right.$ to $5: 95 \mathrm{Et}_{2} \mathrm{O} /$ pentane) to provide the product as a volatile pale yellow oil $(0.086 \mathrm{~g}, 83 \%)$ : $\mathrm{GC} t_{\mathrm{R}}$ (major) $7.77 \mathrm{~min}, t_{\mathrm{R}}$ (minor) $7.83 \mathrm{~min}\left(50{ }^{\circ} \mathrm{C}\right.$ for $1 \mathrm{~min}, 10$ $\circ / \mathrm{min}$, to $\left.150{ }^{\circ} \mathrm{C}\right):{ }^{1} \mathrm{H}$ NMR $\left(500 \mathrm{MHz}, \mathrm{CDCl}_{3}\right) \delta 4.42(\mathrm{dd}, J=11.4,3.3,1 \mathrm{H}), 4.40(\mathrm{dd}, J=9.6$, $4.5,1 \mathrm{H}), 4.00(\mathrm{ddd}, J=12.3,8.1,4.0,1 \mathrm{H}), 3.81(\mathrm{~m}, 2 \mathrm{H}), 3.63(\mathrm{ddd}, J=12.3,4.3,2.5,1 \mathrm{H}), 2.11$ $(\mathrm{dtd}, J=14.9,11.3,3.4,1 \mathrm{H}), 1.96(\mathrm{~m}, 3 \mathrm{H}), 1.80(\mathrm{~m}, 2 \mathrm{H}), 1.70(\mathrm{~m}, 5 \mathrm{H}), 1.63(\mathrm{~m}, 1 \mathrm{H}), 1.50(\mathrm{~m}$, 
$4 \mathrm{H}), 1.40(\mathrm{~m}, 2 \mathrm{H}), 0.97(\mathrm{~d}, J=6.6,3 \mathrm{H}), 0.94(\mathrm{~d}, J=6.7,3 \mathrm{H}) ;{ }^{13} \mathrm{C} \mathrm{NMR}\left(125 \mathrm{MHz}, \mathrm{CDCl}_{3}\right) \delta$ $119.7,118.9,67.62,67.61,67.5,66.8,36.2,35.3,35.0,34.0,33.6,31.3,31.1,30.8,24.4,23.6$, 23.1, 22.6; IR (neat) 2953, 2870, 2254, 1457, 1108, $913 \mathrm{~cm}^{-1}$; HRMS (ES+) $\mathrm{m} / z$ calcd for $\mathrm{C}_{9} \mathrm{H}_{15} \mathrm{NO}\left(\mathrm{M}^{+}\right)$153.1154, found 153.1155. Anal. Calcd for $\mathrm{C}_{9} \mathrm{H}_{15} \mathrm{NO}$ : C, 70.55; H, 9.87; N, 9.14. Found: C, 70.51; H, 10.00; N, 9.18.

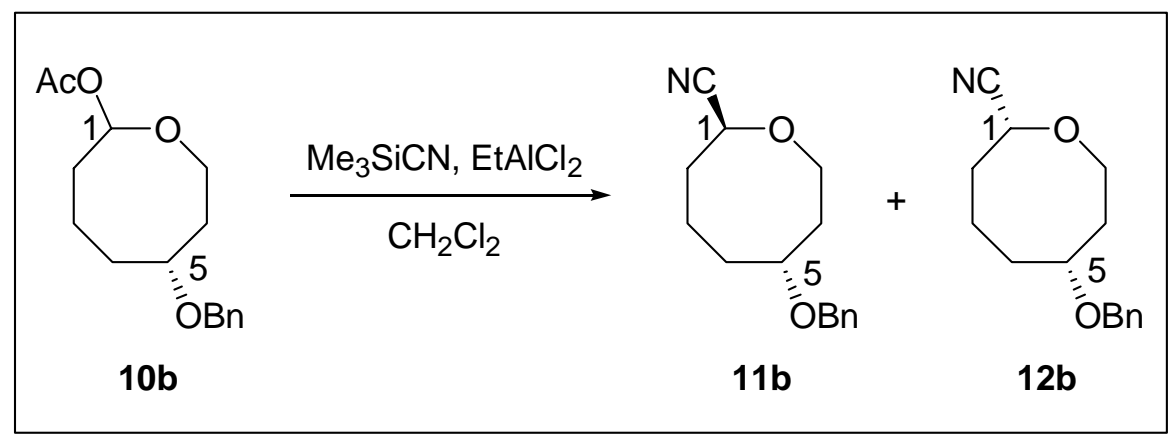

6-(Benzyloxy)oxocane-2-carbonitrile (11b and 12b): Under standard nucleophilic substitution conditions using $\mathrm{EtAlCl}_{2}$ as the Lewis acid, acetate $10 \mathrm{~b}(0.039 \mathrm{~g}, 0.14 \mathrm{mmol})$ afforded the product as an inseparable 80:20 trans:cis mixture of diastereomers $\mathbf{1 1 b}$ and $\mathbf{1 2} \mathbf{b}$. The resulting oil was purified by flash column chromatography on silica gel (10:90 to 20:80 EtOAc/hexanes) to provide the product as a colorless oil $(0.029 \mathrm{~g}, 85 \%): \mathrm{R}_{f}=0.30,20: 80 \mathrm{EtOAc} / \mathrm{hexanes} ; \mathrm{GC} t_{\mathrm{R}}$ (11b-major) $76.13 \mathrm{~min}, t_{\mathrm{R}}\left(\mathbf{1 2 b}\right.$-minor) $75.54 \mathrm{~min}\left(100{ }^{\circ} \mathrm{C}\right.$ for $30 \mathrm{~min}, 1 \% \mathrm{~min}$ to $\left.150{ }^{\circ} \mathrm{C}\right) ;{ }^{1} \mathrm{H}$ NMR (500 MHz, $\left.\mathrm{C}_{6} \mathrm{D}_{6}\right) \delta 7.25(\mathrm{~m}, 2.5 \mathrm{H}), 7.20(\mathrm{~m}, 2.5 \mathrm{H}), 7.11(\mathrm{~m}, 1.25 \mathrm{H}), 4.21(\mathrm{~d}, J=12.6$, $0.25 \mathrm{H}), 4.20(\mathrm{~d}, J=12.1,1 \mathrm{H}), 4.19(\mathrm{~d}, J=12.6,0.25 \mathrm{H}), 4.14(\mathrm{~d}, J=12.1,1 \mathrm{H}), 3.78(\mathrm{ddd}, J=$ $12.6,9.8,3.5,0.25 \mathrm{H}), 3.60(\mathrm{dd}, J=11.2,2.6,1 \mathrm{H}), 3.56(\mathrm{dd}, J=11.4,3.4,0.25 \mathrm{H}), 3.28(\mathrm{ddd}, J=$ $12.6,10.8,3.2,1 \mathrm{H}), 3.19(\mathrm{dt}, J=12.6,4.3,1 \mathrm{H}), 3.16(\mathrm{ddt}, J=9.2,6.6,3.4,1 \mathrm{H}$, and $\mathrm{m}, 0.25 \mathrm{H})$, $3.14(\mathrm{ddd}, J=12.6,6.7,5.1,0.25 \mathrm{H}), 1.76-1.65(\mathrm{~m}, 1.5 \mathrm{H}), 1.63-1.54(\mathrm{~m}, 1.25 \mathrm{H}), 1.52-1.42(\mathrm{~m}$, $2.25 \mathrm{H}), 1.39-1.32(\mathrm{~m}, 1.5 \mathrm{H}), 1.30-1.16(\mathrm{~m}, 3.25 \mathrm{H}), 0.75$ (dddt, $J=14.0,12.1,8.6,2.8,0.25 \mathrm{H}$ ); 
${ }^{13} \mathrm{C}$ NMR $\left(125 \mathrm{MHz}, \mathrm{CDCl}_{3}\right) \delta 138.6,128.4,127.6,127.4,119.1,76.0,70.3,67.3,66.1,32.8$, 32.7, 31.4, 20.0; IR (neat) 2922, 2863, 2356, 1454, 1350, 1251; Anal. Calcd for $\mathrm{C}_{15} \mathrm{H}_{19} \mathrm{NO}_{2}$ : C, 73.44; H, 7.81; N, 5.71. Found: C, 72.35; H, 7.75; N, 5.32.

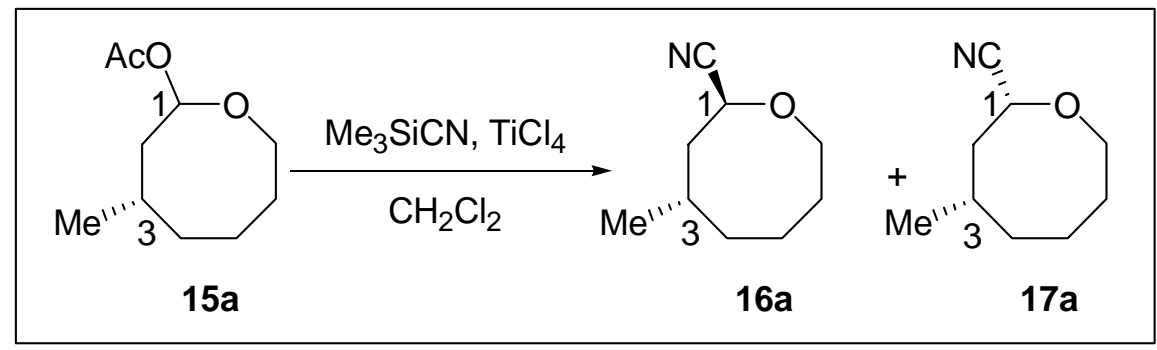

4-Methyloxocane-2-carbonitrile (16a and 17a): Under standard nucleophilic substitution conditions using $\mathrm{TiCl}_{4}$ as the Lewis acid, acetate $15 \mathrm{a}(0.107 \mathrm{~g}, 0.58 \mathrm{mmol})$ afforded $\mathbf{3}$ as an inseparable 18:82 trans:cis mixture of diastereomers $\mathbf{1 7 a}$ and $\mathbf{1 6 a}$ (determined by single-scan ${ }^{1} \mathrm{H}$ NMR spectroscopy). The resulting oil was purified by flash column chromatography on silica gel (5:95 to $20: 80 \mathrm{Et}_{2} \mathrm{O} /$ pentane) to provide the product as a volatile pale yellow oil (0.082 $\mathrm{g}$, 94\%): $\mathrm{R}_{f}=0.25,5: 95 \mathrm{Et}_{2} \mathrm{O} /$ pentane; $\mathrm{GC} t_{\mathrm{R}} 7.72 \mathrm{~min}$ (both diastereomers) $\left(50{ }^{\circ} \mathrm{C}\right.$ for $1 \mathrm{~min}, 10$ \%/min, to $\left.150{ }^{\circ} \mathrm{C}\right):{ }^{1} \mathrm{H} \mathrm{NMR}\left(\mathrm{CDCl}_{3}, 500 \mathrm{MHz}\right) \delta 4.61(\mathrm{dd}, J=10.3,3.8,0.22 \mathrm{H}), 4.47(\mathrm{dd}, J=$ $12.2,2.9,1 \mathrm{H}), 3.84-3.75(\mathrm{~m}, 2.44 \mathrm{H}), 2.22(\mathrm{ddd}, J=15.0,10.3,3.7,0.22 \mathrm{H}), 1.95$ (ddd, $J=14.6$, $12.2,10.7,1 \mathrm{H}), 1.81-1.62(\mathrm{~m}, 4.32 \mathrm{H}$, and dt, $J=14.8,2.7,2.7,1 \mathrm{H}), 1.61-1.54(\mathrm{~m}, 3 \mathrm{H}), 1.53-$ $1.43(\mathrm{~m}, 1.22 \mathrm{H}), 1.34(\mathrm{~m}, 0.22 \mathrm{H}), 0.99(\mathrm{~d}, J=6.9,0.66 \mathrm{H}), 0.97(\mathrm{~d}, J=6.8,3 \mathrm{H}) ;{ }^{13} \mathrm{C} \mathrm{NMR}$ $\left(\mathrm{CDCl}_{3}, 125 \mathrm{MHz}\right) \delta 119.2,119.0,68.3,67.9,67.5,64.6,39.0,36.1,34.5,34.3,31.3,29.9,29.6$, 28.6, 23.9, 23.5, 22.6, 21.3; IR (neat) 2929, 2871, 2254, 1456, 1203, $1108 \mathrm{~cm}^{-1}$; HRMS (EI/GCMS) $m / z$ calcd for $\mathrm{C}_{9} \mathrm{H}_{15} \mathrm{NO}(\mathrm{M})^{+} 153.1154$, found 153.1150. Anal. Calcd for $\mathrm{C}_{9} \mathrm{H}_{15} \mathrm{NO}$ : C, 70.55; H, 9.87; N, 9.14. Found: C, 70.52; H, 9.87; N, 9.09. 


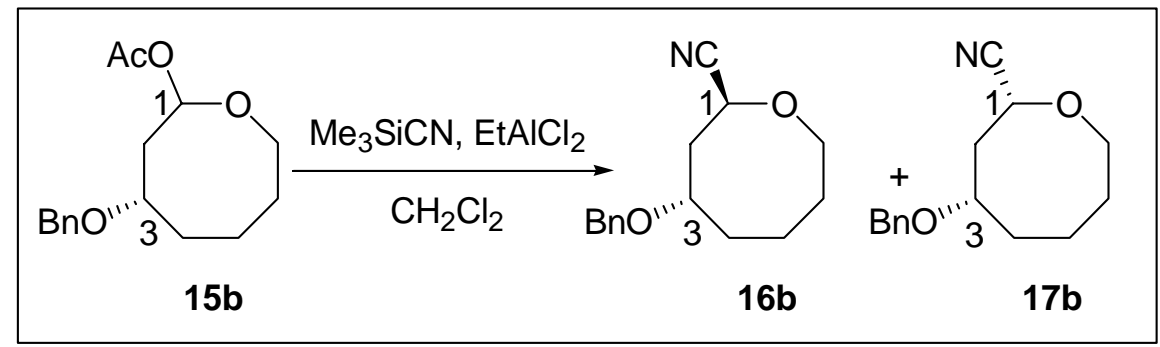

4-(Benzyloxy)oxocane-2-carbonitrile (16b and 17b): Under standard nucleophilic substitution conditions using $\mathrm{EtAlCl}_{2}$ as the Lewis acid, acetate $\mathbf{1 5 b}(0.079 \mathrm{~g}, 0.28 \mathrm{mmol})$ afforded the product as an inseparable 77:23 trans:cis mixture of diastereomers $\mathbf{1 6 b}$ and $\mathbf{1 7 b}$. The resulting mixture was purified by flash column chromatography on silica gel (10:90 to 20:80 EtOAc/hexanes) to provide $\mathbf{1 6 b}$ and $\mathbf{1 7 b}$ as a colorless oil $(0.062 \mathrm{~g}, 89 \%): \mathbf{R}_{f}=0.43,20: 80$ EtOAc/hexanes; GC $t_{\mathrm{R}}$ (16b-major) $6.35 \mathrm{~min}, t_{\mathrm{R}}$ (17b-minor) $6.43 \mathrm{~min}\left(150{ }^{\circ} \mathrm{C}\right.$ for $1 \mathrm{~min}, 10$ \%/min, to $\left.250{ }^{\circ} \mathrm{C}\right):{ }^{1} \mathrm{H} \mathrm{NMR}\left(500 \mathrm{MHz}, \mathrm{CDCl}_{3}\right) \delta 7.36-7.24(\mathrm{~m}, 6.5 \mathrm{H}), 4.80(\mathrm{dd}, J=11.0,2.8$, $1 \mathrm{H}), 4.54(\mathrm{~d}, J=11.9,1 \mathrm{H}), 4.53(\mathrm{~d}, J=12.0,0.3 \mathrm{H}), 4.48(\mathrm{~d}, J=11.9,1 \mathrm{H}$, and $\mathrm{d}, J=12.0,0.3 \mathrm{H})$, $4.47(\mathrm{dd}, J=12.6,2.9,0.3 \mathrm{H}), 3.82-3.78(\mathrm{~m}, 2.6 \mathrm{H}), 3.72(\mathrm{dddd}, J=8.9,5.7,5.3,2.6,1 \mathrm{H}), 3.59$ $(\mathrm{dddd}, J=10.5,4.5,3.9,3.6,0.3 \mathrm{H}), 2.36(\mathrm{ddd}, J=14.8,12.6,10.5,0.3 \mathrm{H}), 2.32(\mathrm{ddd}, J=15.4$, 11.0, 2.6, 1H), $2.12(\mathrm{dt}, J=14.8,3.3,0.3 \mathrm{H}), 2.06(\mathrm{ddd}, J=15.4,5.3,2.8,1 \mathrm{H}$, and $\mathrm{m}, 0.3 \mathrm{H}), 2.03$ $(\mathrm{dddd}, J=14.4,10.2,5.2,1.6,0.3 \mathrm{H}), 1.97(\mathrm{~m}, 0.3 \mathrm{H}), 1.87(\mathrm{dddd}, J=14.4,9.4,8.9,1.6,1 \mathrm{H}$, and $\mathrm{m}, 0.3 \mathrm{H}), 1.82-1.70(\mathrm{~m}, 2.3 \mathrm{H}), 1.65-1.56(\mathrm{~m}, 2.3 \mathrm{H}), 1.32(\mathrm{ddddd}, J=14.4,11.6,9.3,3.9,1.5$, $1 \mathrm{H}) ;{ }^{13} \mathrm{C} \mathrm{NMR}\left(125 \mathrm{MHz}, \mathrm{CDCl}_{3}\right) \delta 138.30,138.27,128.43,127.62,127.60,127.43,127.38(2)$, $119.1,118.4,76.0,74.4,70.5,70.2,68.0,67.6,65.1,63.6,35.3,34.1,32.0,31.2,29.9,28.9,20.6$, 20.4; IR (thin film) 2933, 2867, 2358, 1455, 1359, 1253; HRMS (EI+) $m / z$ calcd for $\mathrm{C}_{15} \mathrm{H}_{19} \mathrm{NO}_{2}$ $(M)^{+}$245.1416, found 245.1420. Anal. Calcd for $\mathrm{C}_{15} \mathrm{H}_{19} \mathrm{NO}_{2}$ : C, 73.44; H, 7.81; N, 5.71. Found: C, 73.70; H, 7.81; N, 5.44. 


\section{Control Experiments}

\section{IVA. Kinetic Control Experiments}

The nucleophilic substitution reactions are under kinetic control, i.e., the addition of cyanide is irreversible, regardless of whether an alkyl or alkoxy substituent is present in the substrate. Resubjection of the minor (1,4-cis) diastereomer of 5(benzyloxy)oxocane-2-carbonitrile (5b) to the reaction conditions gave no reaction. One equivalent of trimethylsilyl acetate was added to maintain the Lewis acidity of the medium since one equivalent is normally produced under the reaction conditions. Three equivalents of trimethylsilyl cyanide were also used, as were 1.2 equivalents of $\mathrm{EtAlCl}_{2}$. The 1,4-cis diastereomer was recovered in $94 \%$ yield. Likewise, resubjection of a 98:2 mixture of the major diastereomer of 5-methyloxocane-2-carbonitrile (5a) $(0.010 \mathrm{~g}, 0.065$ mmol) to the same conditions (instead using 1.2 equivalents of $\mathrm{TiCl}_{4}$ ) gave no reaction, and the same 98:2 ratio was observed in the recovered starting material. Since the same diastereomeric ratio that went into the reaction came out of the reaction, the addition of cyanide is irreversible, and the reaction must be under kinetic control.

\section{IVB. Control Experiments Concerning Initial Ratio of Diastereomeric Lactol} Acetates

(1) Lewis acid is required for nucleophilic substitution to occur. For example, a mixture of trimethylsilyl cyanide and representative lactol acetates $\mathbf{3 a}$ or 3b sits dormant until Lewis acid is added.

(2) The diastereoselectivity of the nucleophilic substitution reactions is largely independent of the diastereomeric ratio of lactol acetates regardless of 
whether an alkyl or alkoxy substituent is present in the substrate. The standard nucleophilic substitution procedure was followed with an 85:15 ratio of acetate $3 \mathrm{a}(0.010 \mathrm{~g}, 0.054 \mathrm{mmol})$ and $\mathrm{TiCl}_{4}$. $\mathrm{GC}$ analysis of the unpurified product showed that cyanohydrin was produced in a 57:43 mixture of diastereomers. Nucleophilic substitution of a 30:70 ratio of acetate 3a $(0.010 \mathrm{~g}, 0.054 \mathrm{mmol})$ under identical conditions provided the product in a 56:44 ratio of diastereomers. The standard nucleophilic substitution procedure was also followed with a $41: 59$ ratio of acetate $\mathbf{1 5 b}$ $(0.004 \mathrm{~g}, 0.014 \mathrm{mmol})$ and $\mathrm{EtAlCl}_{2}$. $\mathrm{GC}$ analysis of the unpurified product showed a 79:21 trans:cis mixture of diastereomers. Nucleophilic substitution of a 78:22 ratio of acetate $\mathbf{1 5 b}(0.007 \mathrm{~g}, 0.025 \mathrm{mmol})$ under identical conditions provided the product in an 85:15 trans:cis ratio of diastereomers.

\section{IVC. Insensitivity of Reaction Selectivities to Conditions}

One reviewer commented about the lack of comparative reaction parameter data in the Lewis acid mediated nucleophilic substitution reactions described in this work, despite footnote 16 in the main text of the paper which mentions that reaction selectivities are insensitive to changes in the solvent or the Lewis acid employed. Some comparative studies were done, and the results appear in the table below. 
Comparing Selectivity Independence When Changing Reaction Conditions

\begin{tabular}{|c|c|c|c|c|c|}
\hline Acetate & Nucleophile & Solvent & Lewis Acid & Temperature & $\begin{array}{l}\text { Selectivity } \\
\text { trans : cis }\end{array}$ \\
\hline $3 a$ & $\mathrm{Me}_{3} \mathrm{SiCN}$ & $\begin{array}{l}\mathrm{CH}_{2} \mathrm{Cl}_{2} \\
\mathrm{CH}_{2} \mathrm{Cl}_{2}\end{array}$ & $\begin{array}{c}\mathrm{TiCl}_{4} \\
\mathrm{EtAlCl}_{2}\end{array}$ & $\begin{array}{r}-78{ }^{\circ} \mathrm{C} \\
-78{ }^{\circ} \mathrm{C} \\
0 \\
{ }^{\circ} \mathrm{C}\end{array}$ & $\begin{array}{l}42: 58^{\star} \\
40: 60 \\
42: 58\end{array}$ \\
\hline $3 b$ & $\mathrm{Me}_{3} \mathrm{SiCN}$ & $\begin{array}{l}\mathrm{CH}_{2} \mathrm{Cl}_{2} \\
\mathrm{CH}_{2} \mathrm{Cl}_{2} \\
\mathrm{PhCH}_{3} \\
\mathrm{EtNO}_{2} \\
\mathrm{THF} \\
\mathrm{CH}_{2} \mathrm{Cl}_{2}\end{array}$ & $\begin{array}{l}\mathrm{EtAlCl}_{2} \\
\\
\mathrm{SnBr}_{4} \\
\mathrm{TiCl}_{4}\end{array}$ & $\begin{aligned} &-78{ }^{\circ} \mathrm{C} \\
& 0{ }^{\circ} \mathrm{C} \\
&-78{ }^{\circ} \mathrm{C} \\
&-78{ }^{\circ} \mathrm{C}\end{aligned}$ & $\begin{array}{c}96: 4^{*} \\
94: 6 \\
94: 6 \\
94: 6 \\
93: 7 \\
98: 2 \\
97: 3\end{array}$ \\
\hline $10 a$ & $\begin{array}{c}\mathrm{Me}_{3} \mathrm{SiCN} \\
\text { PhCCAIEt }_{2} 1\end{array}$ & $\begin{array}{l}\mathrm{CH}_{2} \mathrm{Cl}_{2} \\
\\
: 1 \mathrm{CH}_{2} \mathrm{Cl}_{2}: \\
\mathrm{Et}_{2} \mathrm{O}\end{array}$ & $\begin{array}{c}\mathrm{TiCl}_{4} \\
\mathrm{EtAlCl}_{2} \\
\mathrm{BF}_{3} \mathrm{OEt}_{2} \\
\mathrm{SnCl}_{4} \\
\mathrm{BF}_{3}{ }^{\bullet} \mathrm{OEt}_{2}\end{array}$ & $\begin{array}{l}-78{ }^{\circ} \mathrm{C} \\
-78{ }^{\circ} \mathrm{C} \\
0{ }^{\circ} \mathrm{C}\end{array}$ & $\begin{array}{l}48: 52^{\star} \\
50: 50 \\
49: 51 \\
41: 59 \\
46: 54 \\
50: 50 \\
\end{array}$ \\
\hline $15 a^{\star \star}$ & $\begin{array}{c}\mathrm{Me}_{3} \mathrm{SiCN} \\
\mathrm{PhCCAIEt}_{2}\end{array}$ & $\begin{array}{l}\mathrm{CH}_{2} \mathrm{Cl}_{2} \\
1: \mathrm{CH}_{2} \mathrm{Cl}_{2}: \\
\mathrm{Et}_{2} \mathrm{O}\end{array}$ & $\begin{array}{c}\mathrm{TiCl}_{4} \\
\mathrm{BF}_{3} \mathrm{OEt}_{2}\end{array}$ & $\begin{aligned}-78 & { }^{\circ} \mathrm{C} \\
0 & { }^{\circ} \mathrm{C}\end{aligned}$ & $\begin{array}{l}18: 82^{*} \\
20: 80 \\
25: 75\end{array}$ \\
\hline $15 b$ & $\mathrm{Me}_{3} \mathrm{SiCN}$ & $\mathrm{CH}_{2} \mathrm{Cl}_{2}$ & $\begin{array}{c}\mathrm{EtAlCl}_{2} \\
\mathrm{SnCl}_{4} \\
\mathrm{TiCl}_{4}\end{array}$ & $\begin{array}{r}-78{ }^{\circ} \mathrm{C} \\
0{ }^{\circ} \mathrm{C} \\
-78{ }^{\circ} \mathrm{C}\end{array}$ & $\begin{array}{l}77: 23^{*} \\
75: 25 \\
80: 20 \\
70: 30\end{array}$ \\
\hline
\end{tabular}

*These selectivities were reported in the main text, but are repeated here for comparison. Selectivities $(\mathrm{GC})$ for all other reactions in this table were conducted on analytical scale; therefore, percent yield was not determined. ${ }^{*}$ Selectivities were determined by single-scan ${ }^{1} \mathrm{H} \mathrm{NMR}\left(500 \mathrm{MHz}, \mathrm{CDCl}_{3}\right)$ integration.

\section{Stereochemical Proofs of Nucleophilic Substitution Products}

\section{VA. X-ray Crystallographic Data}

The 1,4-trans relative stereochemistry of the major nucleophilic substitution product 5-benzyloxy-oxocane-2-carbonitrile (4b) was determined after hydrolysis of $\mathbf{4 b}$ to carboxamide 20, whose structure was determined by X-ray crystallography. 


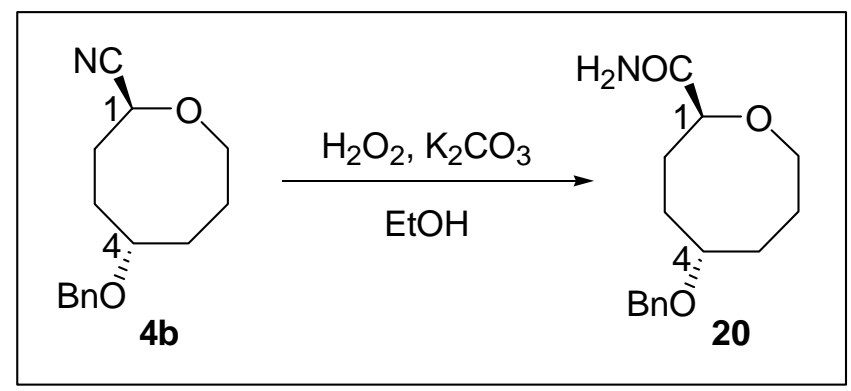

5-Benzyloxy-oxocane-2-carboxamide (20): ${ }^{28}$ To a solution of 1,4-trans isomer $\mathbf{4 b}(0.330 \mathrm{~g}$, $1.35 \mathrm{mmol})$ in $15 \mathrm{~mL}$ of EtOH was added a solution of $\mathrm{K}_{2} \mathrm{CO}_{3}(3.90 \mathrm{~g}, 28.2 \mathrm{mmol})$ in $2.5 \mathrm{~mL}$ of $\mathrm{H}_{2} \mathrm{O}$ followed by $4.4 \mathrm{~mL}$ of $30 \% \mathrm{H}_{2} \mathrm{O}_{2}$. The mixture was stirred at ambient temperature for 12 h, cooled to $0{ }^{\circ} \mathrm{C}$, and then $\mathrm{Na}_{2} \mathrm{~S}_{2} \mathrm{O}_{3} \cdot 7 \mathrm{H}_{2} \mathrm{O}$ was slowly added portionwise by spatula until bubbling ceased. The solution was partially concentrated in vacuo, and the residue was extracted with $3 \times 10 \mathrm{~mL}$ of $\mathrm{CH}_{2} \mathrm{Cl}_{2}$. The combined organic extracts were dried over anhydrous $\mathrm{MgSO}_{4}$, filtered, and concentrated in vacuo. Purification by flash column chromatography on silica gel (EtOAc) afforded the product as a white solid $(0.264 \mathrm{~g}, 75 \%)$. X-ray quality crystals were grown by dissolving the solid in a minimal amount of warm benzene in a 0.5 dram vial that was loosely capped. The 0.5 dram vial was placed in a bed of $n$-hexane within a tightly sealed scintillation vial so vapor diffusion could occur. After several days, colorless crystals were obtained: $\mathrm{mp}$ $48-50{ }^{\circ} \mathrm{C} ; \mathrm{R}_{f}=0.45$, EtOAc; ${ }^{1} \mathrm{H}$ NMR $\left(500 \mathrm{MHz}, \mathrm{C}_{6} \mathrm{D}_{6}\right) \delta 7.30(\mathrm{~m}, 2 \mathrm{H}), 7.19(\mathrm{~m}, 2 \mathrm{H}), 7.10(\mathrm{~m}$, 1H), 5.93 (br s, 1H), 5.25 (br s, 1H), $4.33(\mathrm{~d}, J=12.2,1 \mathrm{H}), 4.26(\mathrm{~d}, J=12.2,1 \mathrm{H}), 3.67$ (tdd, $J=$ $8.4,3.8,2.6,1 \mathrm{H}), 3.57(\mathrm{dd}, J=7.9,3.9,1 \mathrm{H}), 3.32(\mathrm{ddd}, J=12.3,8.6,4.0,1 \mathrm{H}), 2.85(\mathrm{ddd}, J=$ 12.3, 6.1, 3.9, 1H), 2.20 (dddd, $J=14.5,8.4,3.9,3.0,1 \mathrm{H}), 1.89$ (dddd, $J=14.5,8.4,3.0,2.6$, 1H), 1.77 (dddd, $J=14.4,8.4,3.1,1.4,1 \mathrm{H}), 1.74$ (dddd, $J=14.5,8.4,7.9,3.0,1 \mathrm{H}), 1.56$ (dddd, $J=14.4,9.6,8.4,2.6,1 \mathrm{H}), 1.51(\mathrm{dtd}, J=14.5,8.4,3.0,1 \mathrm{H}), 1.39$ (ddddd, $J=12.1,8.6,3.9,2.8$, 1.4, $1 \mathrm{H}), 1.10$ (ddddd, $J=12.1,9.6,6.1,4.0,3.1,1 \mathrm{H}) ;{ }^{13} \mathrm{C} \mathrm{NMR}\left(125 \mathrm{MHz}, \mathrm{CDCl}_{3}\right) \delta 175.4$ 138.9, 128.3, 127.5, 127.4, 78.8, 78.4, 70.2, 70.1, 32.2, 30.2, 29.0, 25.7; IR (KBr pellet) 3175, 
2946, 2855, 1660, 1454, $1106 \mathrm{~cm}^{-1}$; HRMS $\left(\mathrm{CI} / \mathrm{NH}_{3}\right) m / z$ calcd for $\mathrm{C}_{15} \mathrm{H}_{22} \mathrm{NO}_{3}(\mathrm{M}+\mathrm{H})^{+}$ 264.1600, found 264.1592. Anal. Calcd for $\mathrm{C}_{15} \mathrm{H}_{21} \mathrm{NO}_{3}$ : C, 68.42; H, 8.04; N, 5.32. Found: $\mathrm{C}$, $68.44 ; \mathrm{H}, 7.84 ; \mathrm{N}, 4.58$. 
X-ray crystallography data for $\mathbf{2 0}$

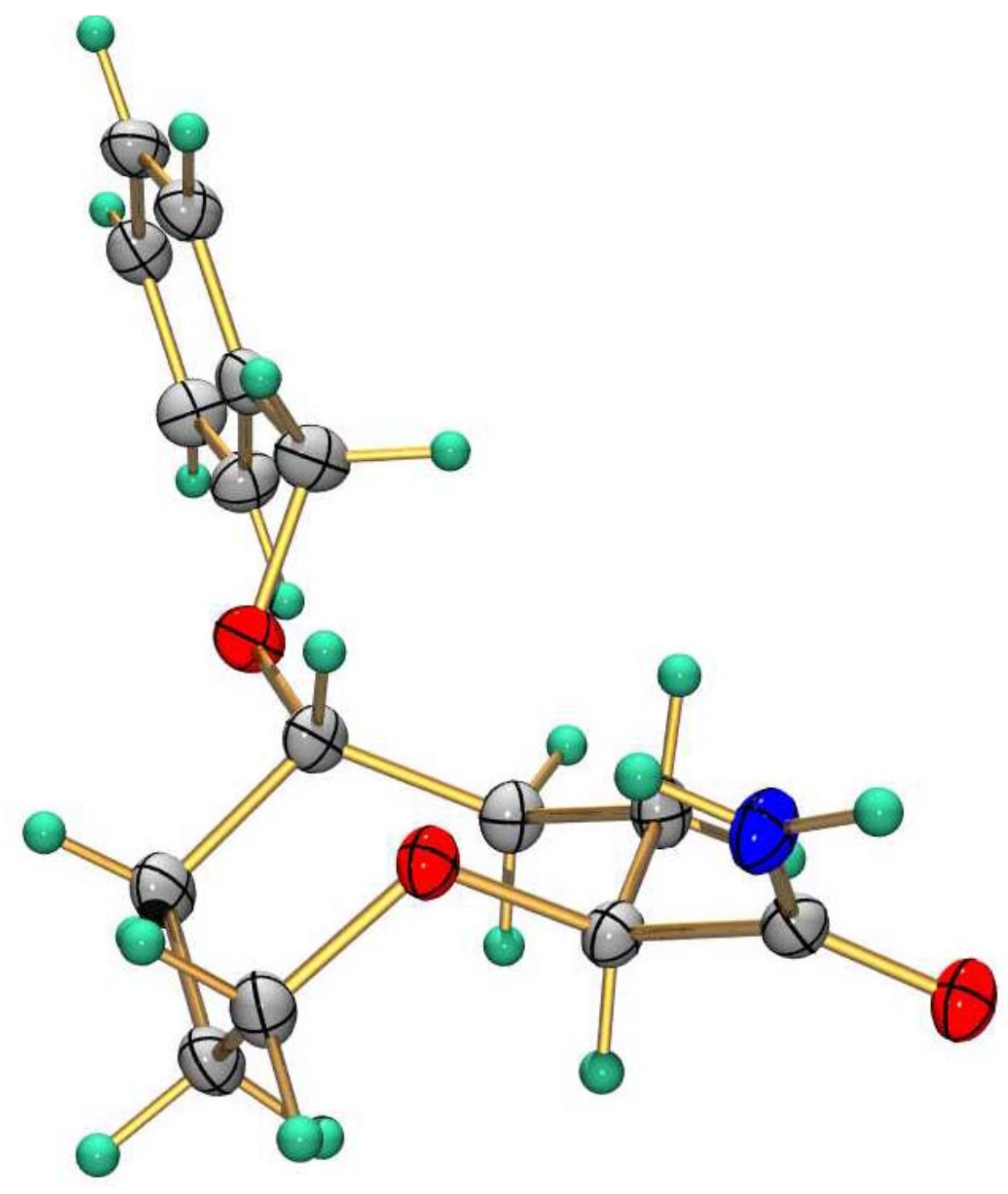

X-ray Data Collection, Structure Solution and Refinement for $\mathbf{2 0 .}$

A colorless crystal of approximate dimensions $0.24 \times 0.30 \times 0.38 \mathrm{~mm}$ was mounted on a glass fiber and transferred to a Bruker CCD platform diffractometer. The SMART ${ }^{1}$ program package 
was used to determine the unit-cell parameters and for data collection $(25 \mathrm{sec} /$ frame scan time for a sphere of diffraction data). The raw frame data was processed using SAINT $^{2}$ and $\mathrm{SADABS}^{3}$ to yield the reflection data file. Subsequent calculations were carried out using the SHELXTL $^{4}$ program. There were no systematic absences nor any diffraction symmetry other than the Friedel condition. The centrosymmetric triclinic space group $\mathrm{P} \overline{1}$ was assigned and later determined to be correct.

The structure was solved by direct methods and refined on $\mathrm{F}^{2}$ by full-matrix least-squares techniques. The analytical scattering factors ${ }^{5}$ for neutral atoms were used throughout the analysis. Hydrogen atoms were located from a difference-Fourier map and refined (x,y,z and $\mathrm{U}_{\text {iso }}$ ). There was one-half molecule of benzene solvent present per formula unit. The benzene solvent molecule was located about an inversion center. At convergence, wR2 $=0.1522$ and Goof $=1.059$ for 295 variables refined against 3814 data. As a comparison for refinement on $\mathrm{F}$, $\mathrm{R} 1=0.0536$ for those 3211 data with $\mathrm{I}>2.0 \sigma(\mathrm{I})$.

References.

1. SMART Software Users Guide, Version 5.1, Bruker Analytical X-Ray Systems, Inc.; Madison, WI 1999.

2. SAINT Software Users Guide, Version 6.0, Bruker Analytical X-Ray Systems, Inc.; Madison, WI 1999.

3. Sheldrick, G. M. SADABS, Version 2.03, Bruker Analytical X-Ray Systems, Inc.; Madison, WI 2000.

4. Sheldrick, G. M. SHELXTL Version 5.10, Bruker Analytical X-Ray Systems, Inc.; Madison, WI 1999.

5. International Tables for X-Ray Crystallography 1992, Vol. C., Dordrecht: Kluwer AcademicPublishers.

\section{Definitions:}

$\mathrm{wR} 2=\left[\Sigma\left[\mathrm{w}\left(\mathrm{F}_{\mathrm{o}}^{2}-\mathrm{F}_{\mathrm{c}}{ }^{2}\right)^{2}\right] / \Sigma\left[\mathrm{w}\left(\mathrm{F}_{\mathrm{o}}{ }^{2}\right)^{2}\right]^{1 / 2}\right.$

$\mathrm{R} 1=\Sigma|| \mathrm{F}_{\mathrm{o}}|-| \mathrm{F}_{\mathrm{c}} \| / \Sigma\left|\mathrm{F}_{\mathrm{o}}\right|$

Goof $=\mathrm{S}=\left[\Sigma\left[\mathrm{w}\left(\mathrm{F}_{\mathrm{o}}^{2}-\mathrm{F}_{\mathrm{c}}{ }^{2}\right)^{2}\right] /(\mathrm{n}-\mathrm{p})\right]^{1 / 2}$ where $\mathrm{n}$ is the number of reflections and $\mathrm{p}$ is the total number of parameters refined.

The thermal ellipsoid plot is shown at the $50 \%$ probability level.

Table 1. Crystal data and structure refinement for $\mathbf{2 0}$.

Identification code

Empirical formula

Formula weight kaw37 (Stephen Chamberland)

$\mathrm{C}_{15} \mathrm{H}_{21} \mathrm{~N} \mathrm{O}_{3} \bullet 1 / 2\left(\mathrm{C}_{6} \mathrm{H}_{6}\right)$

302.38 
Temperature

Wavelength

Crystal system

Space group

Unit cell dimensions

Volume

$\mathrm{Z}$

Density (calculated)

Absorption coefficient

$\mathrm{F}(000)$

Crystal size

Theta range for data collection

Index ranges

Reflections collected

Independent reflections

Completeness to theta $=28.38^{\circ}$

Absorption correction

Max. and min. transmission

Refinement method

Data / restraints / parameters

Goodness-of-fit on $\mathrm{F}^{2}$

Final $\mathrm{R}$ indices [I > 2sigma(I)]

$\mathrm{R}$ indices (all data)

Largest diff. peak and hole
173(2) K

$0.71073 \AA$

Triclinic

$P \overline{1}$

$\mathrm{a}=5.2748(3) \AA$ $\alpha=94.2720(10)^{\circ}$.

$\mathrm{b}=10.1002(6) \AA$ $\beta=94.6620(10)^{\circ}$.

$\mathrm{c}=15.4153(9) \AA$

811.74(8) $\AA^{3}$

2

$1.237 \mathrm{Mg} / \mathrm{m}^{3}$

$0.084 \mathrm{~mm}^{-1}$

326

$0.38 \times 0.30 \times 0.24 \mathrm{~mm}^{3}$

2.03 to $28.38^{\circ}$.

$-6 \leq h \leq 6,-13 \leq k \leq 13,-20 \leq l \leq 20$

8683

$3814[\mathrm{R}(\mathrm{int})=0.0233]$

$93.8 \%$

None

0.9802 and 0.9689

Full-matrix least-squares on $\mathrm{F}^{2}$

3814 / 0 / 295

1.059

$\mathrm{R} 1=0.0536, \mathrm{wR} 2=0.1419$

$\mathrm{R} 1=0.0627, \mathrm{wR} 2=0.1522$

0.578 and -0.192 e. $\AA^{-3}$ 
Table 2. Atomic coordinates ( $\left.\mathrm{x} 10^{4}\right)$ and equivalent isotropic displacement parameters $\left(\AA^{2} \mathrm{x}\right.$ $\left.10^{3}\right)$ for $\mathbf{2 0}$. $\mathrm{U}(\mathrm{eq})$ is defined as one third of the trace of the orthogonalized $\mathrm{U}^{\mathrm{ij}}$ tensor.

\begin{tabular}{lrrrr}
\hline & $\mathrm{x}$ & $\mathrm{y}$ & $\mathrm{z}$ & $\mathrm{U}(\mathrm{eq})$ \\
\hline $\mathrm{O}(1)$ & $-3411(2)$ & $2265(1)$ & $7873(1)$ & $21(1)$ \\
$\mathrm{O}(2)$ & $1825(2)$ & $4089(1)$ & $9203(1)$ & $24(1)$ \\
$\mathrm{O}(3)$ & $-2780(2)$ & $2015(1)$ & $5114(1)$ & $27(1)$ \\
$\mathrm{N}(1)$ & $-2472(2)$ & $4062(1)$ & $9229(1)$ & $24(1)$ \\
$\mathrm{C}(1)$ & $-767(2)$ & $2719(1)$ & $8069(1)$ & $20(1)$ \\
$\mathrm{C}(2)$ & $294(3)$ & $3411(1)$ & $7304(1)$ & $23(1)$ \\
$\mathrm{C}(3)$ & $147(3)$ & $2536(1)$ & $6442(1)$ & $24(1)$ \\
$\mathrm{C}(4)$ & $-2566(3)$ & $1984(1)$ & $6052(1)$ & $23(1)$ \\
$\mathrm{C}(5)$ & $-3313(3)$ & $516(1)$ & $6194(1)$ & $26(1)$ \\
$\mathrm{C}(6)$ & $-2715(3)$ & $98(1)$ & $7116(1)$ & $25(1)$ \\
$\mathrm{C}(7)$ & $-3969(3)$ & $836(1)$ & $7830(1)$ & $24(1)$ \\
$\mathrm{C}(8)$ & $-382(2)$ & $3689(1)$ & $8893(1)$ & $20(1)$ \\
$\mathrm{C}(9)$ & $-3319(3)$ & $3271(2)$ & $4840(1)$ & $28(1)$ \\
$\mathrm{C}(10)$ & $-3401(3)$ & $3224(1)$ & $3859(1)$ & $24(1)$ \\
$\mathrm{C}(11)$ & $-5218(3)$ & $3846(1)$ & $3382(1)$ & $26(1)$ \\
$\mathrm{C}(12)$ & $-5272(3)$ & $3822(1)$ & $2477(1)$ & $28(1)$ \\
$\mathrm{C}(13)$ & $-3497(3)$ & $3174(1)$ & $2039(1)$ & $28(1)$ \\
$\mathrm{C}(14)$ & $-1684(3)$ & $2542(2)$ & $2508(1)$ & $30(1)$ \\
$\mathrm{C}(15)$ & $-1628(3)$ & $2565(2)$ & $3413(1)$ & $28(1)$ \\
$\mathrm{C}(16)$ & $213(3)$ & $1331(2)$ & $10330(1)$ & $30(1)$ \\
$\mathrm{C}(17)$ & $2005(3)$ & $887(2)$ & $9794(1)$ & $30(1)$ \\
$\mathrm{C}(18)$ & $1786(3)$ & $-439(2)$ & $9466(1)$ & $31(1)$ \\
& & & & \\
\hline
\end{tabular}


Table 3. Bond lengths $[\AA]$ and angles $\left[{ }^{\circ}\right]$ for $\mathbf{2 0}$.

\begin{tabular}{ll}
\hline $\mathrm{O}(1)-\mathrm{C}(1)$ & $1.4251(15)$ \\
$\mathrm{O}(1)-\mathrm{C}(7)$ & $1.4396(16)$ \\
$\mathrm{O}(2)-\mathrm{C}(8)$ & $1.2389(16)$ \\
$\mathrm{O}(3)-\mathrm{C}(9)$ & $1.4143(17)$ \\
$\mathrm{O}(3)-\mathrm{C}(4)$ & $1.4454(15)$ \\
$\mathrm{N}(1)-\mathrm{C}(8)$ & $1.3310(18)$ \\
$\mathrm{C}(1)-\mathrm{C}(2)$ & $1.5319(19)$ \\
$\mathrm{C}(1)-\mathrm{C}(8)$ & $1.5323(17)$ \\
$\mathrm{C}(2)-\mathrm{C}(3)$ & $1.5326(18)$ \\
$\mathrm{C}(3)-\mathrm{C}(4)$ & $1.5399(19)$ \\
$\mathrm{C}(4)-\mathrm{C}(5)$ & $1.5320(19)$ \\
$\mathrm{C}(5)-\mathrm{C}(6)$ & $1.5304(19)$ \\
$\mathrm{C}(6)-\mathrm{C}(7)$ & $1.5162(19)$ \\
$\mathrm{C}(9)-\mathrm{C}(10)$ & $1.5078(19)$ \\
$\mathrm{C}(10)-\mathrm{C}(11)$ & $1.388(2)$ \\
$\mathrm{C}(10)-\mathrm{C}(15)$ & $1.397(2)$ \\
$\mathrm{C}(11)-\mathrm{C}(12)$ & $1.391(2)$ \\
$\mathrm{C}(12)-\mathrm{C}(13)$ & $1.386(2)$ \\
$\mathrm{C}(13)-\mathrm{C}(14)$ & $1.386(2)$ \\
$\mathrm{C}(14)-\mathrm{C}(15)$ & $1.392(2)$ \\
$\mathrm{C}(16)-\mathrm{C}(18) \# 1$ & $1.390(2)$ \\
$\mathrm{C}(16)-\mathrm{C}(17)$ & $1.390(2)$ \\
$\mathrm{C}(17)-\mathrm{C}(18)$ & $1.387(2)$ \\
$\mathrm{C}(18)-\mathrm{C}(16) \# 1$ & $1.390(2)$ \\
$\mathrm{C}(1)-\mathrm{O}(1)-\mathrm{C}(7)$ & $113.90(10)$ \\
$\mathrm{C}(9)-\mathrm{O}(3)-\mathrm{C}(4)$ & $112.96(10)$ \\
$\mathrm{O}(1)-\mathrm{C}(1)-\mathrm{C}(2)$ & $110.58(10)$ \\
$\mathrm{O}(1)-\mathrm{C}(1)-\mathrm{C}(8)$ & $110.35(10)$ \\
$\mathrm{C}(2)-\mathrm{C}(1)-\mathrm{C}(8)$ & $109.58(11)$ \\
$\mathrm{C}(1)-\mathrm{C}(2)-\mathrm{C}(3)$ & $115.33(11)$ \\
$\mathrm{C}(2)-\mathrm{C}(3)-\mathrm{C}(4)$ & $115.60(11)$ \\
$\mathrm{O}(3)-\mathrm{C}(4)-\mathrm{C}(5)$ & $104.08(10)$ \\
$\mathrm{O}(3)-\mathrm{C}(4)-\mathrm{C}(3)$ & $110.48(11)$ \\
&
\end{tabular}




$\begin{array}{ll}\mathrm{C}(5)-\mathrm{C}(4)-\mathrm{C}(3) & 114.46(11) \\ \mathrm{C}(6)-\mathrm{C}(5)-\mathrm{C}(4) & 116.51(11) \\ \mathrm{C}(7)-\mathrm{C}(6)-\mathrm{C}(5) & 115.36(12) \\ \mathrm{O}(1)-\mathrm{C}(7)-\mathrm{C}(6) & 113.81(11) \\ \mathrm{O}(2)-\mathrm{C}(8)-\mathrm{N}(1) & 123.83(12) \\ \mathrm{O}(2)-\mathrm{C}(8)-\mathrm{C}(1) & 118.93(11) \\ \mathrm{N}(1)-\mathrm{C}(8)-\mathrm{C}(1) & 117.24(11) \\ \mathrm{O}(3)-\mathrm{C}(9)-\mathrm{C}(10) & 109.12(11) \\ \mathrm{C}(11)-\mathrm{C}(10)-\mathrm{C}(15) & 118.79(13) \\ \mathrm{C}(11)-\mathrm{C}(10)-\mathrm{C}(9) & 120.74(12) \\ \mathrm{C}(15)-\mathrm{C}(10)-\mathrm{C}(9) & 120.47(12) \\ \mathrm{C}(10)-\mathrm{C}(11)-\mathrm{C}(12) & 120.85(13) \\ \mathrm{C}(13)-\mathrm{C}(12)-\mathrm{C}(11) & 120.13(13) \\ \mathrm{C}(12)-\mathrm{C}(13)-\mathrm{C}(14) & 119.52(13) \\ \mathrm{C}(13)-\mathrm{C}(14)-\mathrm{C}(15) & 120.40(14) \\ \mathrm{C}(14)-\mathrm{C}(15)-\mathrm{C}(10) & 120.30(13) \\ \mathrm{C}(18) \# 1-\mathrm{C}(16)-\mathrm{C}(17) & 119.63(14) \\ \mathrm{C}(18)-\mathrm{C}(17)-\mathrm{C}(16) & 119.90(15) \\ \mathrm{C}(17)-\mathrm{C}(18)-\mathrm{C}(16) \# 1 & 120.47(14)\end{array}$

Symmetry transformations used to generate equivalent atoms:

$\# 1-\mathrm{x},-\mathrm{y},-\mathrm{z}+2$ 
Table 4. Anisotropic displacement parameters $\left(\AA^{2} \mathrm{x} 10^{3}\right)$ for 20. The anisotropic displacement factor exponent takes the form: $-2 \pi^{2}\left[h^{2} a^{* 2} U^{11}+\ldots+2 h k a^{*} b^{*} U^{12}\right]$

\begin{tabular}{lllllll}
\hline & $\mathrm{U}^{11}$ & $\mathrm{U}^{22}$ & $\mathrm{U}^{33}$ & $\mathrm{U}^{23}$ & $\mathrm{U}^{13}$ & $\mathrm{U}^{12}$ \\
\hline $\mathrm{O}(1)$ & $21(1)$ & $22(1)$ & $20(1)$ & $-3(1)$ & $0(1)$ & $1(1)$ \\
$\mathrm{O}(2)$ & $23(1)$ & $28(1)$ & $21(1)$ & $-5(1)$ & $0(1)$ & $1(1)$ \\
$\mathrm{O}(3)$ & $41(1)$ & $24(1)$ & $15(1)$ & $-1(1)$ & $0(1)$ & $5(1)$ \\
$\mathrm{N}(1)$ & $23(1)$ & $28(1)$ & $19(1)$ & $-7(1)$ & $-1(1)$ & $3(1)$ \\
$\mathrm{C}(1)$ & $20(1)$ & $22(1)$ & $18(1)$ & $-1(1)$ & $0(1)$ & $2(1)$ \\
$\mathrm{C}(2)$ & $25(1)$ & $23(1)$ & $18(1)$ & $-2(1)$ & $2(1)$ & $-1(1)$ \\
$\mathrm{C}(3)$ & $26(1)$ & $27(1)$ & $17(1)$ & $-1(1)$ & $4(1)$ & $2(1)$ \\
$\mathrm{C}(4)$ & $29(1)$ & $23(1)$ & $14(1)$ & $-2(1)$ & $1(1)$ & $3(1)$ \\
$\mathrm{C}(5)$ & $34(1)$ & $23(1)$ & $20(1)$ & $-3(1)$ & $0(1)$ & $0(1)$ \\
$\mathrm{C}(6)$ & $31(1)$ & $19(1)$ & $23(1)$ & $0(1)$ & $1(1)$ & $1(1)$ \\
$\mathrm{C}(7)$ & $27(1)$ & $22(1)$ & $22(1)$ & $1(1)$ & $2(1)$ & $-2(1)$ \\
$\mathrm{C}(8)$ & $23(1)$ & $20(1)$ & $16(1)$ & $2(1)$ & $0(1)$ & $2(1)$ \\
$\mathrm{C}(9)$ & $40(1)$ & $26(1)$ & $20(1)$ & $1(1)$ & $3(1)$ & $8(1)$ \\
$\mathrm{C}(10)$ & $30(1)$ & $22(1)$ & $20(1)$ & $1(1)$ & $3(1)$ & $0(1)$ \\
$\mathrm{C}(11)$ & $31(1)$ & $24(1)$ & $24(1)$ & $1(1)$ & $3(1)$ & $5(1)$ \\
$\mathrm{C}(12)$ & $35(1)$ & $25(1)$ & $25(1)$ & $4(1)$ & $-1(1)$ & $6(1)$ \\
$\mathrm{C}(13)$ & $38(1)$ & $27(1)$ & $19(1)$ & $4(1)$ & $3(1)$ & $0(1)$ \\
$\mathrm{C}(14)$ & $32(1)$ & $34(1)$ & $24(1)$ & $0(1)$ & $6(1)$ & $6(1)$ \\
$\mathrm{C}(15)$ & $29(1)$ & $32(1)$ & $23(1)$ & $2(1)$ & $1(1)$ & $6(1)$ \\
$\mathrm{C}(16)$ & $38(1)$ & $29(1)$ & $24(1)$ & $3(1)$ & $1(1)$ & $5(1)$ \\
$\mathrm{C}(17)$ & $33(1)$ & $33(1)$ & $25(1)$ & $7(1)$ & $3(1)$ & $2(1)$ \\
$\mathrm{C}(18)$ & $34(1)$ & $35(1)$ & $25(1)$ & $4(1)$ & $7(1)$ & $9(1)$ \\
- & & & & & & \\
\hline
\end{tabular}


Table 5. Hydrogen coordinates ( $\left.\times 10^{4}\right)$ and isotropic displacement parameters $\left(\AA^{2} \times 10^{3}\right)$ for 20.

\begin{tabular}{lrrrr}
\hline & $\mathrm{x}$ & $\mathrm{y}$ & $\mathrm{z}$ & $\mathrm{U}(\mathrm{eq})$ \\
\hline $\mathrm{H}(1)$ & $-4010(40)$ & $3774(18)$ & $9007(12)$ & $29(4)$ \\
$\mathrm{H}(2)$ & $-2330(40)$ & $4670(20)$ & $9689(15)$ & $42(5)$ \\
$\mathrm{H}(1 \mathrm{~A})$ & $200(30)$ & $1996(16)$ & $8200(11)$ & $21(4)$ \\
$\mathrm{H}(2 \mathrm{~A})$ & $-670(30)$ & $4177(17)$ & $7210(11)$ & $26(4)$ \\
$\mathrm{H}(2 \mathrm{~B})$ & $2070(40)$ & $3753(18)$ & $7485(12)$ & $30(4)$ \\
$\mathrm{H}(3 \mathrm{~A})$ & $1280(30)$ & $1801(18)$ & $6507(12)$ & $28(4)$ \\
$\mathrm{H}(3 \mathrm{~B})$ & $960(40)$ & $3107(19)$ & $6040(13)$ & $37(5)$ \\
$\mathrm{H}(4 \mathrm{~A})$ & $-3800(30)$ & $2555(15)$ & $6318(10)$ & $16(3)$ \\
$\mathrm{H}(5 \mathrm{~A})$ & $-5130(40)$ & $281(17)$ & $6035(12)$ & $29(4)$ \\
$\mathrm{H}(5 \mathrm{~B})$ & $-2430(40)$ & $-4(19)$ & $5781(14)$ & $39(5)$ \\
$\mathrm{H}(6 \mathrm{~A})$ & $-790(30)$ & $183(15)$ & $7268(10)$ & $19(4)$ \\
$\mathrm{H}(6 \mathrm{~B})$ & $-3270(30)$ & $-877(17)$ & $7126(11)$ & $26(4)$ \\
$\mathrm{H}(7 \mathrm{~A})$ & $-5890(30)$ & $678(15)$ & $7731(11)$ & $20(4)$ \\
$\mathrm{H}(7 \mathrm{~B})$ & $-3440(40)$ & $514(19)$ & $8400(13)$ & $37(5)$ \\
$\mathrm{H}(9 \mathrm{~A})$ & $-5100(30)$ & $3489(18)$ & $5021(12)$ & $31(4)$ \\
$\mathrm{H}(9 \mathrm{~B})$ & $-1970(40)$ & $4020(20)$ & $5097(13)$ & $38(5)$ \\
$\mathrm{H}(11)$ & $-6480(40)$ & $4320(20)$ & $3716(14)$ & $46(6)$ \\
$\mathrm{H}(12)$ & $-6570(30)$ & $4251(17)$ & $2157(12)$ & $27(4)$ \\
$\mathrm{H}(13)$ & $-3520(40)$ & $3172(19)$ & $1408(14)$ & $39(5)$ \\
$\mathrm{H}(14)$ & $-430(40)$ & $2075(19)$ & $2210(13)$ & $37(5)$ \\
$\mathrm{H}(15)$ & $-310(30)$ & $2119(17)$ & $3757(12)$ & $28(4)$ \\
$\mathrm{H}(16)$ & $410(40)$ & $2240(20)$ & $10554(13)$ & $38(5)$ \\
$\mathrm{H}(17)$ & $3470(40)$ & $1486(18)$ & $9681(12)$ & $34(5)$ \\
$\mathrm{H}(18)$ & $3060(40)$ & $-762(19)$ & $9086(13)$ & $38(5)$ \\
& & & & \\
\hline
\end{tabular}


Table 6. Torsion angles $\left[{ }^{\circ}\right]$ for $\mathbf{2 0 .}$

\begin{tabular}{lc}
\hline $\mathrm{C}(7)-\mathrm{O}(1)-\mathrm{C}(1)-\mathrm{C}(2)$ & $116.13(12)$ \\
$\mathrm{C}(7)-\mathrm{O}(1)-\mathrm{C}(1)-\mathrm{C}(8)$ & $-122.47(11)$ \\
$\mathrm{O}(1)-\mathrm{C}(1)-\mathrm{C}(2)-\mathrm{C}(3)$ & $-60.79(15)$ \\
$\mathrm{C}(8)-\mathrm{C}(1)-\mathrm{C}(2)-\mathrm{C}(3)$ & $177.36(11)$ \\
$\mathrm{C}(1)-\mathrm{C}(2)-\mathrm{C}(3)-\mathrm{C}(4)$ & $61.53(16)$ \\
$\mathrm{C}(9)-\mathrm{O}(3)-\mathrm{C}(4)-\mathrm{C}(5)$ & $152.93(12)$ \\
$\mathrm{C}(9)-\mathrm{O}(3)-\mathrm{C}(4)-\mathrm{C}(3)$ & $-83.75(14)$ \\
$\mathrm{C}(2)-\mathrm{C}(3)-\mathrm{C}(4)-\mathrm{O}(3)$ & $140.58(12)$ \\
$\mathrm{C}(2)-\mathrm{C}(3)-\mathrm{C}(4)-\mathrm{C}(5)$ & $-102.35(14)$ \\
$\mathrm{O}(3)-\mathrm{C}(4)-\mathrm{C}(5)-\mathrm{C}(6)$ & $166.99(12)$ \\
$\mathrm{C}(3)-\mathrm{C}(4)-\mathrm{C}(5)-\mathrm{C}(6)$ & $46.31(17)$ \\
$\mathrm{C}(4)-\mathrm{C}(5)-\mathrm{C}(6)-\mathrm{C}(7)$ & $59.27(17)$ \\
$\mathrm{C}(1)-\mathrm{O}(1)-\mathrm{C}(7)-\mathrm{C}(6)$ & $-62.46(15)$ \\
$\mathrm{C}(5)-\mathrm{C}(6)-\mathrm{C}(7)-\mathrm{O}(1)$ & $-55.77(16)$ \\
$\mathrm{O}(1)-\mathrm{C}(1)-\mathrm{C}(8)-\mathrm{O}(2)$ & $173.58(11)$ \\
$\mathrm{C}(2)-\mathrm{C}(1)-\mathrm{C}(8)-\mathrm{O}(2)$ & $-64.43(15)$ \\
$\mathrm{O}(1)-\mathrm{C}(1)-\mathrm{C}(8)-\mathrm{N}(1)$ & $-7.07(16)$ \\
$\mathrm{C}(2)-\mathrm{C}(1)-\mathrm{C}(8)-\mathrm{N}(1)$ & $114.92(13)$ \\
$\mathrm{C}(4)-\mathrm{O}(3)-\mathrm{C}(9)-\mathrm{C}(10)$ & $177.73(11)$ \\
$\mathrm{O}(3)-\mathrm{C}(9)-\mathrm{C}(10)-\mathrm{C}(11)$ & $140.36(14)$ \\
$\mathrm{O}(3)-\mathrm{C}(9)-\mathrm{C}(10)-\mathrm{C}(15)$ & $-40.33(19)$ \\
$\mathrm{C}(15)-\mathrm{C}(10)-\mathrm{C}(11)-\mathrm{C}(12)$ & $-0.4(2)$ \\
$\mathrm{C}(9)-\mathrm{C}(10)-\mathrm{C}(11)-\mathrm{C}(12)$ & $178.94(13)$ \\
$\mathrm{C}(10)-\mathrm{C}(11)-\mathrm{C}(12)-\mathrm{C}(13)$ & $0.0(2)$ \\
$\mathrm{C}(11)-\mathrm{C}(12)-\mathrm{C}(13)-\mathrm{C}(14)$ & $0.5(2)$ \\
$\mathrm{C}(12)-\mathrm{C}(13)-\mathrm{C}(14)-\mathrm{C}(15)$ & $-0.5(2)$ \\
$\mathrm{C}(13)-\mathrm{C}(14)-\mathrm{C}(15)-\mathrm{C}(10)$ & $0.1(2)$ \\
$\mathrm{C}(11)-\mathrm{C}(10)-\mathrm{C}(15)-\mathrm{C}(14)$ & $0.4(2)$ \\
$\mathrm{C}(9)-\mathrm{C}(10)-\mathrm{C}(15)-\mathrm{C}(14)$ & $-178.96(14)$ \\
$\mathrm{C}(18) \# 1-\mathrm{C}(16)-\mathrm{C}(17)-\mathrm{C}(18)$ & $0.1(2)$ \\
$\mathrm{C}(16)-\mathrm{C}(17)-\mathrm{C}(18)-\mathrm{C}(16) \# 1$ & $-0.1(2)$ \\
- & \\
\hline
\end{tabular}

Symmetry transformations used to generate equivalent atoms:

$\# 1-\mathrm{x},-\mathrm{y},-\mathrm{z}+2$ 
VB. Relevant ${ }^{1} \mathrm{H}$ NMR Coupling Constant Data

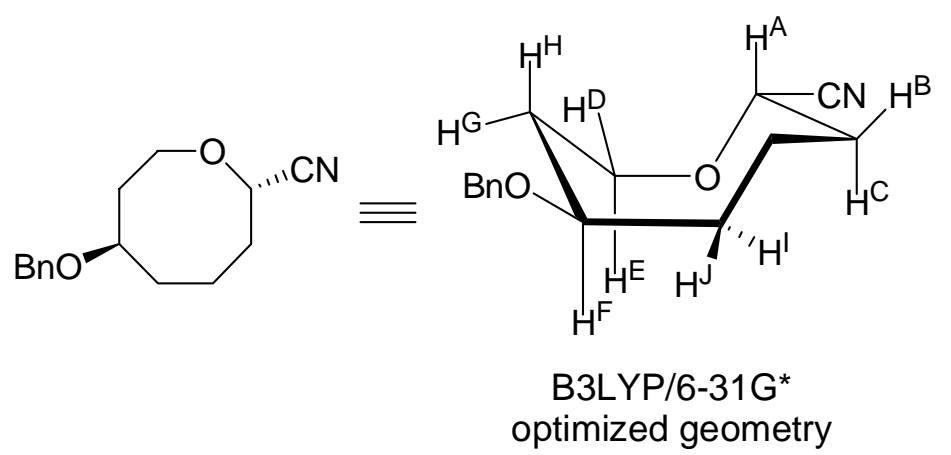

trans-6-(Benzyloxy)oxocane-2-carbonitrile (11b, major)

$\mathbf{H}^{\mathrm{A}}: \mathrm{dd}, J=11.2\left(\mathrm{ax}^{\mathrm{A}}-\mathrm{ax}^{\mathrm{C}}\right), 2.6\left(\mathrm{ax}^{\mathrm{A}}-\mathrm{eq}^{\mathrm{B}}\right)$

$\mathbf{H}^{\mathrm{F}}$ : ddt, $J=9.2\left(\mathrm{ax}^{\mathrm{F}}-\mathrm{ax}^{\mathrm{H}}\right), 6.6,6.6$, and 3.4 (to $\mathrm{H}^{\mathrm{G}}, \mathrm{H}^{\mathrm{I}}$, and $\left.\mathrm{H}^{\mathrm{J}}\right)$
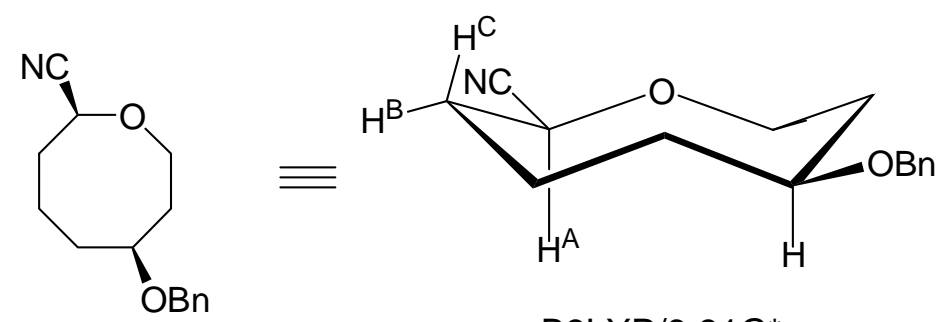

B3LYP/6-31G* optimized geometry

cis-6-(Benzyloxy)oxocane-2-carbonitrile (12b, minor)

$\mathbf{H}^{\mathrm{A}}: \mathrm{dd}, J=11.4\left(\mathrm{ax}^{\mathrm{A}}-\mathrm{ax}^{\mathrm{C}}\right), 3.4\left(\mathrm{ax}^{\mathrm{A}}-\mathrm{eq}^{\mathrm{B}}\right)$

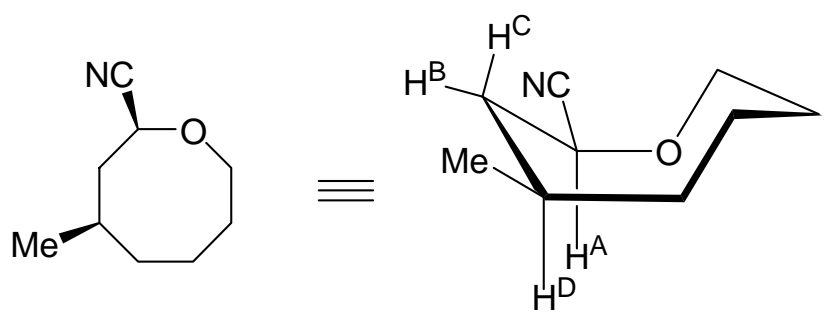

B3LYP/6-31G*

optimized geometry 
cis-4-Methyloxocane-2-carbonitrile (17a, major)
$\mathbf{H}^{\mathrm{A}}: \mathrm{dd}, J=12.3\left(\mathrm{ax}^{\mathrm{A}}-\mathrm{ax}^{\mathrm{C}}\right), 2.9\left(\mathrm{ax}^{\mathrm{A}}-\mathrm{eq}^{\mathrm{B}}\right)$
$\mathbf{H}^{\mathrm{B}}: \mathrm{dt}, J=14.8(\mathrm{gem}), 2.7\left(\mathrm{eq}^{\mathrm{B}}-\mathrm{ax}^{\mathrm{A}}\right), 2.7\left(\mathrm{eq}^{\mathrm{B}}-\mathrm{ax}^{\mathrm{D}}\right)$
$\mathbf{H}^{\mathrm{C}}: \operatorname{ddd}, J=14.8($ gem $), 12.2\left(\mathrm{ax}^{\mathrm{C}}-\mathrm{ax}^{\mathrm{A}}\right), 10.7\left(\mathrm{ax}^{\mathrm{C}}-\mathrm{ax}^{\mathrm{D}}\right)$<smiles>C[C@H]1CCCCO[C@@H](C#N)C1</smiles>

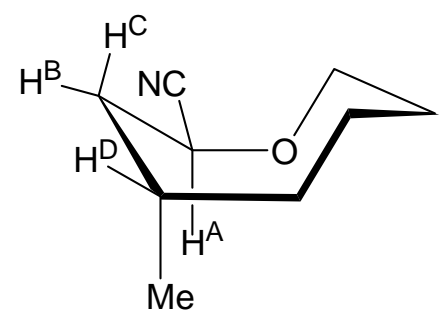

B3LYP/6-31G*

optimized geometry

trans-4-Methyloxocane-2-carbonitrile (16a, minor)
$\mathbf{H}^{\mathrm{A}}: \mathrm{dd}, J=10.0\left(\mathrm{ax}^{\mathrm{A}}-\mathrm{ax}^{\mathrm{C}}\right), 3.8\left(\mathrm{ax}^{\mathrm{A}}-\mathrm{eq}^{\mathrm{B}}\right)$
$\mathbf{H}^{\mathrm{C}}: \operatorname{ddd}, J=15.0(\mathrm{gem}), 10.0\left(\mathrm{ax}^{\mathrm{C}}-\mathrm{ax}^{\mathrm{A}}\right), 3.7\left(\mathrm{ax}^{\mathrm{C}}-\mathrm{eq}^{\mathrm{D}}\right)$
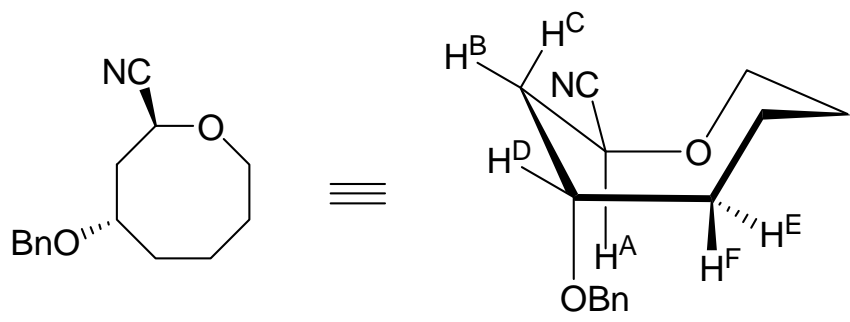

B3LYP/6-31G*

optimized geometry

trans-4-(Benzyloxy)oxocane-2-carbonitrile (16b, major)
$\mathbf{H}^{\mathrm{A}}: \mathrm{dd}, J=10.8\left(\mathrm{ax}^{\mathrm{A}}-\mathrm{ax}^{\mathrm{C}}\right), 3.0\left(\mathrm{ax}^{\mathrm{A}}-\mathrm{eq}^{\mathrm{B}}\right)$
$\mathbf{H}^{\mathrm{C}}: \operatorname{ddd}, J=15.4(\mathrm{gem}), 10.8\left(\mathrm{ax}^{\mathrm{C}}-\mathrm{ax}^{\mathrm{A}}\right), 2.6\left(\mathrm{ax}^{\mathrm{C}}-\mathrm{eq}^{\mathrm{D}}\right)$
$\mathbf{H}^{\mathrm{D}}:$ dddd, $J=8.9\left(\mathrm{eq}^{\mathrm{D}}-\mathrm{in}^{\mathrm{E}}\right), 5.7\left(\mathrm{eq}^{\mathrm{D}}-\mathrm{out}^{\mathrm{F}}\right), 5.3\left(\mathrm{eq}^{\mathrm{D}}-\mathrm{eq}^{\mathrm{B}}\right), 2.6\left(\mathrm{eq}^{\mathrm{D}}-\mathrm{ax}^{\mathrm{C}}\right)$ 
<smiles>CCC[C@@H](CC(O)C#N)OBr</smiles>

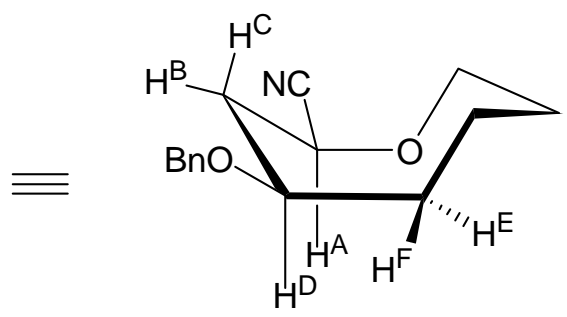

B3LYP/6-31G* optimized geometry

cis-4-(Benzyloxy)oxocane-2-carbonitrile (17b, minor)

$\mathbf{H}^{\mathrm{A}}: \mathrm{dd}, J=12.6\left(\mathrm{ax}^{\mathrm{A}}-\mathrm{ax}^{\mathrm{C}}\right), 2.9\left(\mathrm{ax}^{\mathrm{A}}-\mathrm{eq}^{\mathrm{B}}\right)$

$\mathbf{H}^{\mathrm{C}}: \operatorname{ddd}, J=14.8(\mathrm{gem}), 12.6\left(\mathrm{ax}^{\mathrm{C}}-\mathrm{ax}^{\mathrm{A}}\right), 10.5\left(\mathrm{ax}^{\mathrm{C}}-\mathrm{ax}^{\mathrm{D}}\right)$

$\mathbf{H}^{\mathrm{D}}$ : dddd, $J=10.5\left(\mathrm{ax}^{\mathrm{D}}-\mathrm{ax}^{\mathrm{C}}\right), 4.5,3.9$, and $3.6\left(\mathrm{ax}^{\mathrm{D}}-\mathrm{H}^{\mathrm{B}}, \mathrm{H}^{\mathrm{F}}\right.$, and $\left.\mathrm{eq}^{\mathrm{B}}\right)$

\section{VC. DPFGSE-NOE and 2D-NOESY Data}

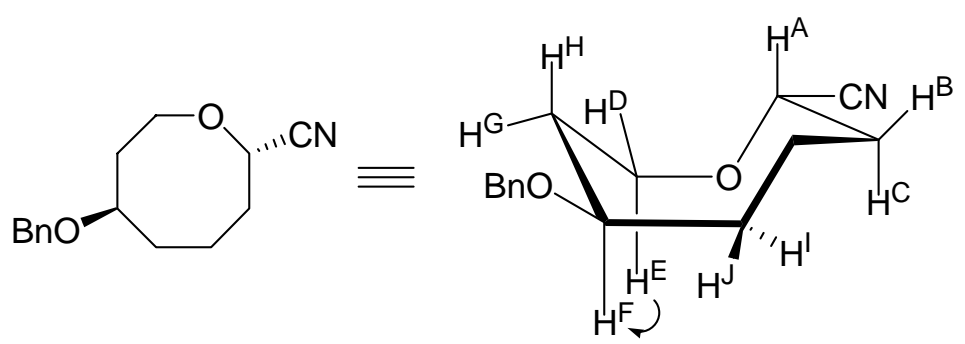

trans-6-(Benzyloxy)oxocane-2-carbonitrile (11b, major)

$\mathbf{H}^{\mathrm{E}}$ irradiated: $\mathrm{H}^{\mathrm{F}}(2.76 \%)$

The following key 2D-NOESY crosspeaks were observed: $\mathrm{H}^{\mathrm{E}}$ to $\mathrm{H}^{\mathrm{F}} ; \mathrm{H}^{\mathrm{A}}$ to both $\mathrm{H}^{\mathrm{D}}$ and $\mathrm{H}^{\mathrm{H}}$

Mixing time was $1.0 \mathrm{~s}$ for both 1D-NOE and 2D-NOESY experiments. 

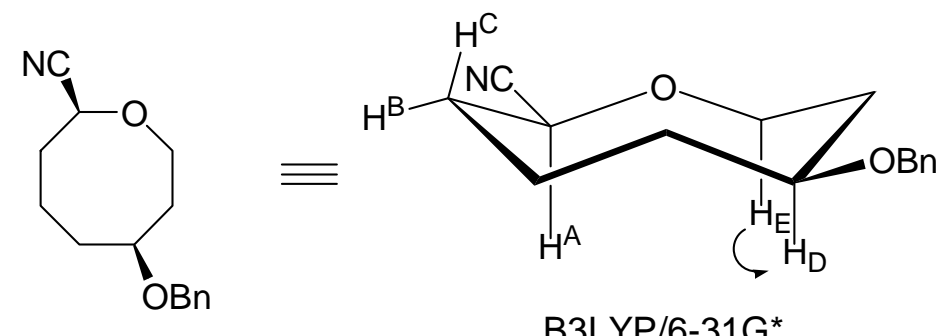

B3LYP/6-31G*

optimized geometry

cis-6-(Benzyloxy)oxocane-2-carbonitrile (12b, minor)

$\mathbf{H}^{\mathrm{E}}$ irradiated: $\mathrm{H}^{\mathrm{D}}(1.52 \%)$

A 2D-NOESY crosspeak was observed between $\mathrm{H}^{\mathrm{E}}$ and $\mathrm{H}^{\mathrm{D}}$.
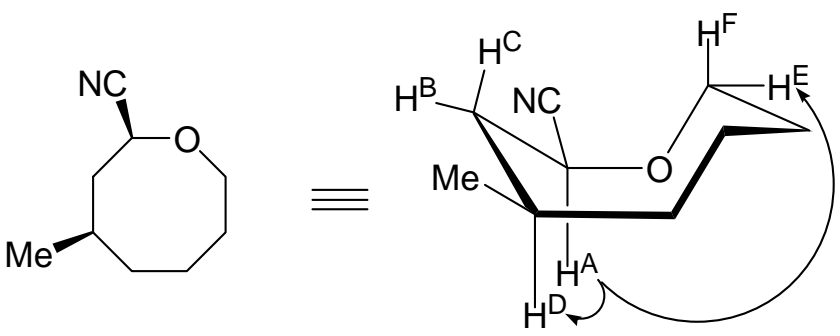

cis-4-Methyloxocane-2-carbonitrile (17a, major)

$\mathbf{H}^{\mathrm{A}}$ irradiated: $\mathrm{H}^{\mathrm{D}}(0.62 \%), \mathrm{H}^{\mathrm{E}}(0.51 \%)$;

Methyl irradiated: no nOe with HA

No 2D-NOESY crosspeak was observed between C3-Methyl and $\mathrm{H}^{\mathrm{A}}$.

A 2D-NOESY crosspeak was observed between $\mathrm{H}^{\mathrm{C}}$ and $\mathrm{H}^{\mathrm{F}}$.

Mixing time was $1.0 \mathrm{~s}$ for both 1D-NOE and 2D-NOESY experiments. 

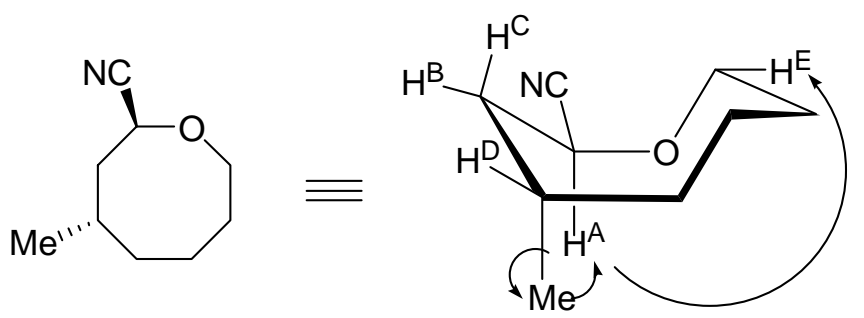

trans-4-Methyloxocane-2-carbonitrile (16a, minor)

$\mathbf{H}^{\mathrm{A}}$ irradiated: C3-Methyl (2.55\%), $\mathrm{H}^{\mathrm{E}}(0.21 \%)$;

Methyl irradiated: $\mathrm{H}^{\mathrm{A}}(1.32 \%)$

A 2D-NOESY crosspeak was observed between C3-Methyl and $\mathrm{H}^{\mathrm{A}}$.

Mixing time was $1.0 \mathrm{~s}$ for both 1D-NOE and 2D-NOESY experiments.
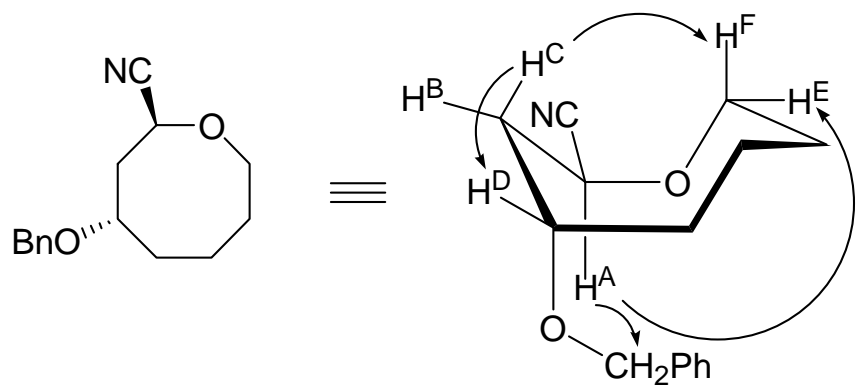

trans-4-(Benzyloxy)oxocane-2-carbonitrile (16b, major)

$\mathbf{H}^{\mathrm{A}}$ irradiated: $\mathrm{H}^{\mathrm{E}}(0.32 \%), \mathrm{H}_{2}^{\mathrm{OCH}}{ }_{2}^{\mathrm{Bn}}(0.20 \%)$

$\mathbf{H}^{\mathrm{C}}$ irradiated: $\mathrm{H}^{\mathrm{D}}(4.21 \%), \mathrm{H}^{\mathrm{F}}(1.68 \%)$

$\mathbf{H}^{\mathrm{D}}$ irradiated: no NOE with $\mathrm{H}^{\mathrm{A}}$

Mixing time was $1.0 \mathrm{~s}$. 

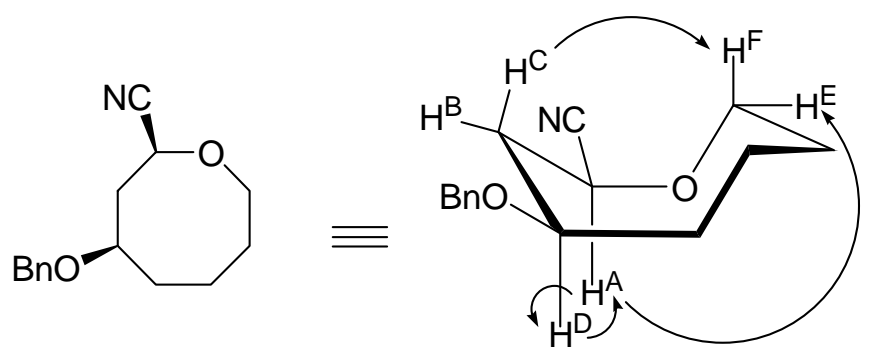

cis-4-(Benzyloxy)oxocane-2-carbonitrile (17b, minor)

$\mathbf{H}^{\mathrm{A}}$ irradiated: $\mathrm{H}^{\mathrm{A}}(2.44 \%), \mathrm{H}^{\mathrm{E}}(0.14 \%)$

$\mathbf{H}^{\mathrm{C}}$ irradiated: $\mathrm{H}^{\mathrm{F}}(0.14 \%)$

$\mathbf{H}^{\mathrm{D}}$ irradiated: $\mathrm{H}^{\mathrm{A}}(2.30 \%)$

Mixing time was $1.0 \mathrm{~s}$. 
VI. Computational Studies to Predict Nucleophilic Substitution Product Ratios

- Parent (Unsubstituted) Oxocarbenium ion

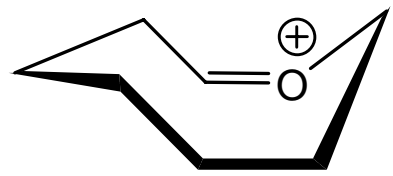

1

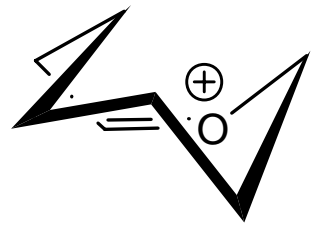

S33

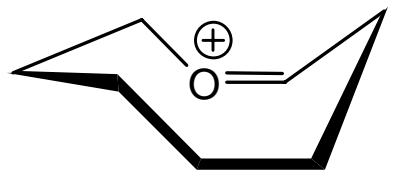

2

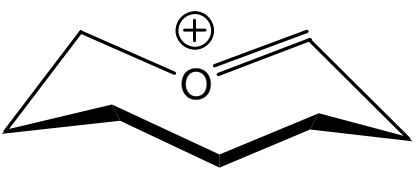

S34

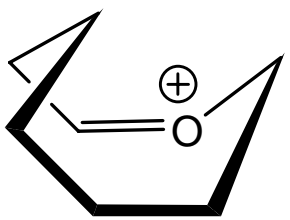

S32

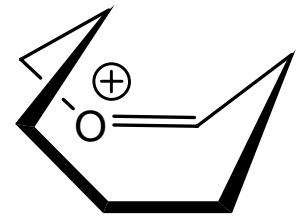

S35

\begin{tabular}{|cc|}
\hline Cation & $\mathrm{E}_{\mathrm{rel}}(\mathrm{kcal} / \mathrm{mol})$ \\
\hline $\mathbf{1}$ & 0 \\
$\mathbf{2}$ & 0.1 \\
S32 & 2.2 \\
S33 & 3.7 \\
S34 & $4.2^{*}$ \\
S35 & 4.3 \\
\hline
\end{tabular}

* Energy difference between $\mathbf{1}$ and $\mathbf{S 3 4}$ indicates that a (Z)-oxocarbenium ion is $4.2 \mathrm{kcal} / \mathrm{mol}$ more stable than an $(E)$-oxocarbenium ion in an eight-membered ring (B3LYP/6-31G*).

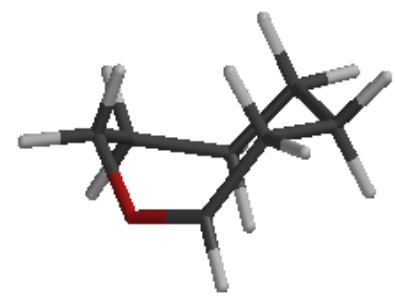




\section{1}

SPARTAN 'O2 Quantum Mechanics Program:

Job type: Geometry optimization.

Method: RB3LYP

Basis set: $6-31 \mathrm{G}(\mathrm{D})$

Number of shells: 58

Number of basis functions: 146

SCF model:

A restricted hybrid HF-DFT SCF calculation will be performed using Pulay DIIS extrapolation

Optimization:

$\begin{array}{rc}\text { Step } & \text { Energy } \\ 1 & -349.5158915 \\ 2 & -349.5183237 \\ 3 & -349.5185461 \\ 4 & -349.5185680 \\ 5 & -349.5185757 \\ 6 & -349.5185739 \\ 7 & -349.5185740\end{array}$

$$
\begin{array}{r}
\text { Max Grad. } \\
0.019236
\end{array}
$$

Max Dist.

0.057549

$0.004505 \quad 0.040433$

$0.001155 \quad 0.018792$

$0.000431 \quad 0.017378$

$0.000126 \quad 0.005468$

$0.000058 \quad 0.002928$

$0.000022 \quad 0.000911$

Dipole Moment (Debye) Tot 3.2838

* * GEOMETRY OPTIMIZATION IN DELOCALIZED INTERNAL COORDINATES * * searching for a Minimum

\begin{tabular}{|c|c|c|c|c|}
\hline \multirow[b]{2}{*}{ ATOM } & \multicolumn{3}{|c|}{ Coordinates (Angstroms) } & \\
\hline & $\mathrm{X}$ & $\mathrm{Y}$ & $\mathrm{Z}$ & \\
\hline $1 \mathrm{H}$ & -2.399014 & -1.223199 & 0.587350 & \\
\hline $\mathrm{C}$ & -1.589259 & -0.794724 & -0.011554 & \\
\hline $\mathrm{H}$ & -1.318270 & 1.927397 & -1.578856 & \\
\hline $\mathrm{C}$ & 0.943751 & -1.107613 & -0.557866 & \\
\hline $\mathrm{C}$ & 1.905456 & -0.028141 & -0.024146 & \\
\hline $\mathrm{C}$ & -0.260124 & -1.482318 & 0.334685 & \\
\hline $\mathrm{C}$ & -1.657881 & 0.755891 & 0.287085 & \\
\hline $\mathrm{H}$ & 2.454359 & -0.410912 & 0.846811 & \\
\hline $\mathrm{H}$ & 0.588012 & -0.825366 & -1.559275 & \\
\hline $\mathrm{H}$ & 2.655207 & 0.197677 & -0.789688 & \\
\hline $\mathrm{H}$ & -0.023639 & -1.329384 & 1.396956 & \\
\hline $\mathrm{H}$ & -2.697268 & 1.079404 & 0.175681 & \\
\hline $\mathrm{H}$ & -1.848736 & -0.971483 & -1.061607 & \\
\hline $\mathrm{H}$ & -1.340347 & 0.928497 & 1.319776 & \\
\hline $\mathrm{H}$ & 1.557389 & -1.999331 & -0.724211 & \\
\hline $\mathrm{C}$ & 1.273797 & 1.272406 & 0.458744 & \\
\hline $\mathrm{H}$ & -0.447255 & -2.557265 & 0.231145 & \\
\hline $\mathrm{C}$ & -0.856865 & 1.530538 & -0.670697 & \\
\hline $\mathrm{H}$ & 0.685144 & 1.162021 & 1.369251 & \\
\hline $\mathrm{O}$ & 0.374225 & 1.801687 & -0.609537 & \\
\hline $\mathrm{H}$ & 2.001318 & 2.074219 & 0.579952 & \\
\hline
\end{tabular}

Optimization Cycle: 7

Energy is $\quad-349.518574016$ 


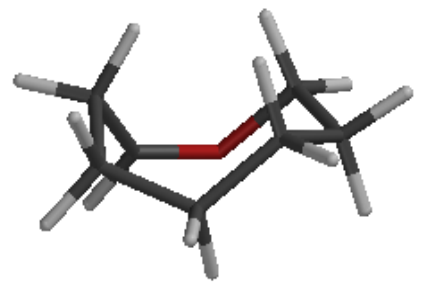

\section{2}

SPARTAN 'O2 Quantum Mechanics Program:

Job type: Geometry optimization.

Method: RB3LYP

Basis set: $6-31 G(D)$

Number of shells: 58

Number of basis functions: 146

SCF model:

A restricted hybrid HF-DFT SCF calculation will be performed using Pulay DIIS extrapolation

Optimization:

$\begin{array}{rc}\text { Step } & \text { Energy } \\ 1 & -349.5156595 \\ 2 & -349.5181198 \\ 3 & -349.5183149 \\ 4 & -349.5183440 \\ 5 & -349.5183505 \\ 6 & -349.5183520 \\ 7 & -349.5183528\end{array}$

$$
\begin{array}{r}
\text { Max Grad. } \\
0.023848
\end{array}
$$

Max Dist.

0.051803

$0.004198 \quad 0.038436$

$0.001461 \quad 0.023906$

$0.000390 \quad 0.012326$

$0.000168 \quad 0.001668$

$0.000084 \quad 0.002183$

$0.000017 \quad 0.001003$

Dipole Moment (Debye) Tot 3.3581

* * GEOMETRY OPTIMIZATION IN DELOCALIZED INTERNAL COORDINATES ** Searching for a Minimum

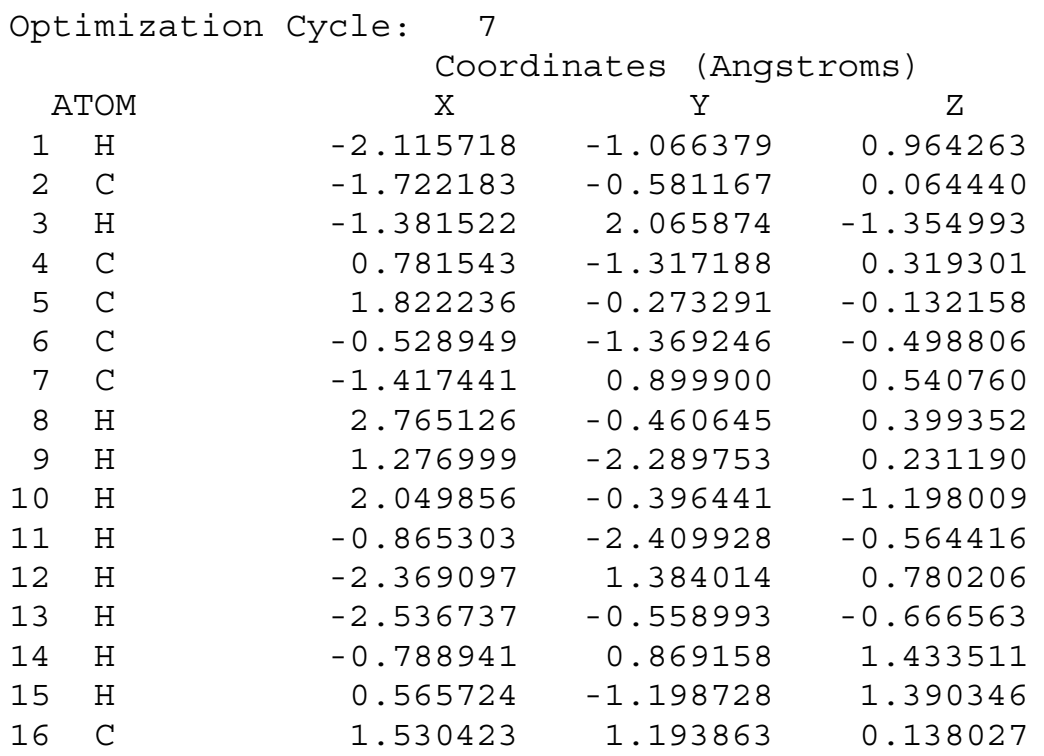




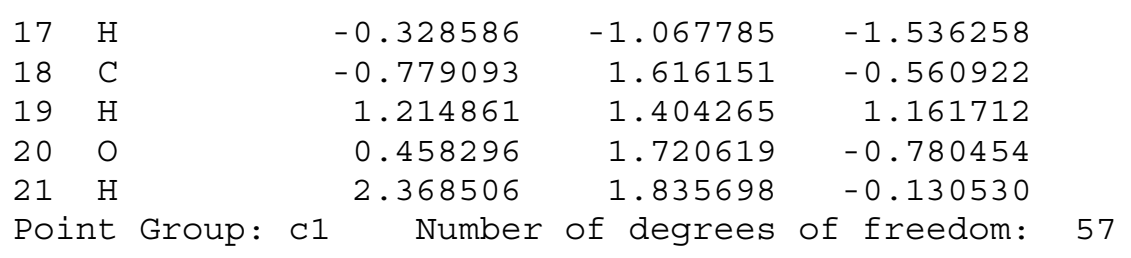

Energy is $\quad-349.518352767$

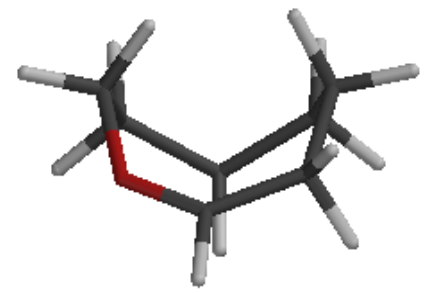

S32

SPARTAN 'O2 Quantum Mechanics Program:

Job type: Geometry optimization.

Method: RB3LYP

Basis set: $6-31 G(D)$

Number of shells: 58

Number of basis functions: 146

SCF model:

A restricted hybrid HF-DFT SCF calculation will be performed using Pulay DIIS extrapolation

Optimization:

$\begin{array}{rc}\text { Step } & \text { Energy } \\ 1 & -349.5125532 \\ 2 & -349.5149967 \\ 3 & -349.5151188 \\ 4 & -349.5151359 \\ 5 & -349.5151439 \\ 6 & -349.5151425\end{array}$

Max Grad.
0.016425
0.002830
0.000886
0.000609
0.000216
0.000124

Max Dist.

0.059650

0.056188

$-349.5149967$

0.024747

$-349.5151425$

0.000124

0.018644

0.007210

0.001011

Dipole Moment (Debye) Tot 3.5178

* * GEOMETRY OPTIMIZATION IN DELOCALIZED INTERNAL COORDINATES * * Searching for a Minimum

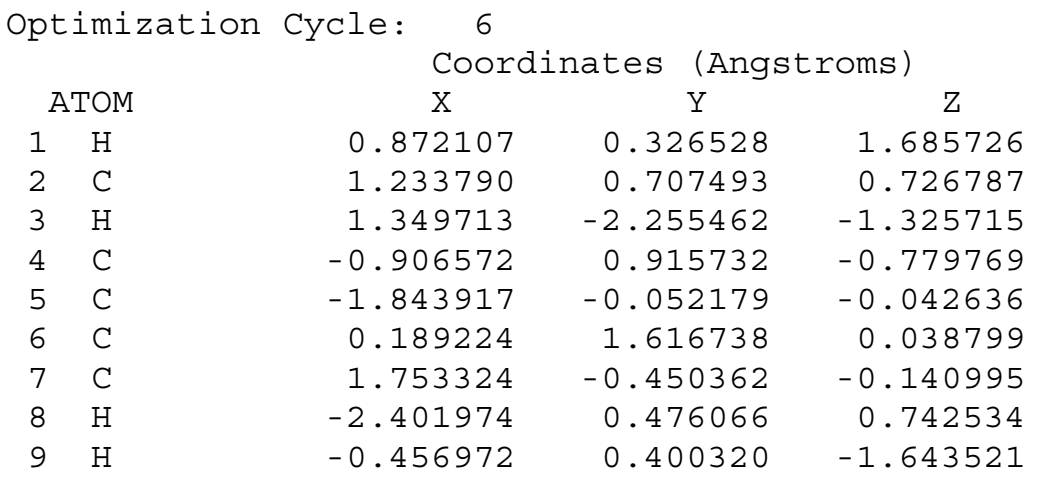




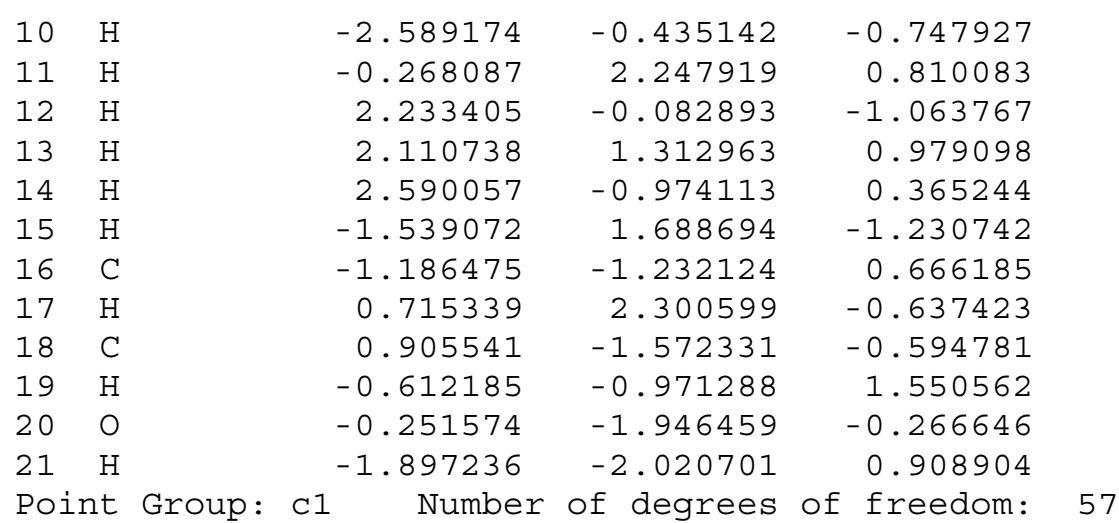

Energy is $\quad-349.515142547$

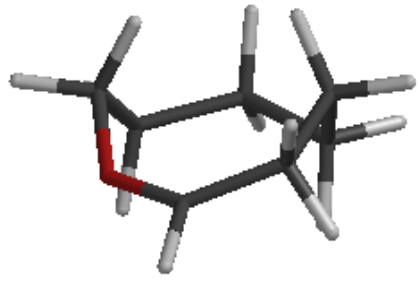

S33

SPARTAN 'O2 Quantum Mechanics Program:

Job type: Geometry optimization.

Method: RB3LYP

Basis set: $6-31 \mathrm{G}(\mathrm{D})$

Number of shells: 58

Number of basis functions: 146

SCF model:

A restricted hybrid HF-DFT SCF calculation will be performed using Pulay DIIS extrapolation

Optimization:

$\begin{array}{rc}\text { Step } & \text { Energy } \\ 1 & -349.5102495 \\ 2 & -349.5118094 \\ 3 & -349.5123531 \\ 4 & -349.5126396 \\ 5 & -349.5127066 \\ 6 & -349.5127278 \\ 7 & -349.5127409 \\ 8 & -349.5127482 \\ 9 & -349.5127462 \\ 10 & -349.5127482 \\ 11 & -349.5127512\end{array}$

Max Grad.
0.015680
0.010305
0.007206
0.003278
0.001587
0.000991
0.000472
0.000307
0.000111
0.000096
0.000086

Max Dist. 0.089154

0.101430

0.058324

0.054723

0.011285

0.009782

0.019415

0.007109

0.002493

0.004078

0.000924

Dipole Moment (Debye) Tot 4.0285

* * GEOMETRY OPTIMIZATION IN DELOCALIZED INTERNAL COORDINATES ** Searching for a Minimum 


\begin{tabular}{|c|c|c|c|c|}
\hline \multirow{2}{*}{\multicolumn{2}{|c|}{$\begin{array}{l}\text { Optimization } \\
\text { ATOM }\end{array}$}} & \multicolumn{3}{|c|}{$\begin{array}{ll}\text { Cycle: } & 11 \\
& \text { Coordinates (Angstroms) }\end{array}$} \\
\hline & & $\mathrm{X}$ & $\mathrm{Y}$ & $\mathrm{Z}$ \\
\hline 1 & $\mathrm{H}$ & 0.655350 & -0.751694 & -1.542957 \\
\hline 2 & $\mathrm{C}$ & 1.053454 & -1.021232 & -0.558960 \\
\hline 3 & $\mathrm{H}$ & 2.072366 & 2.008797 & 1.086270 \\
\hline 4 & $\mathrm{C}$ & -1.480109 & -0.970993 & 0.059114 \\
\hline 5 & $\mathrm{C}$ & -1.751871 & 0.523523 & 0.282371 \\
\hline 6 & $\mathrm{C}$ & -0.076381 & -1.500194 & 0.387038 \\
\hline 7 & $\mathrm{C}$ & 1.937347 & 0.100976 & 0.004720 \\
\hline 8 & $\mathrm{H}$ & -2.786576 & 0.736177 & -0.012967 \\
\hline 9 & $\mathrm{H}$ & -2.204456 & -1.521044 & 0.670393 \\
\hline 10 & $\mathrm{H}$ & -1.691191 & 0.793792 & 1.344640 \\
\hline 11 & $\mathrm{H}$ & -0.122316 & -2.592173 & 0.327951 \\
\hline 12 & $\mathrm{H}$ & 2.528157 & -0.265143 & 0.860903 \\
\hline 13 & $\mathrm{H}$ & 1.743163 & -1.849917 & -0.747105 \\
\hline 14 & $\mathrm{H}$ & 2.726389 & 0.398575 & -0.716530 \\
\hline 15 & $\mathrm{H}$ & -1.717037 & -1.221910 & -0.983948 \\
\hline 16 & $\mathrm{C}$ & -0.888679 & 1.495811 & -0.515218 \\
\hline 17 & $\mathrm{H}$ & 0.184505 & -1.274782 & 1.431256 \\
\hline 18 & $\mathrm{C}$ & 1.406617 & 1.392324 & 0.473547 \\
\hline 19 & $\mathrm{H}$ & -0.507680 & 1.105742 & -1.458639 \\
\hline 20 & O & 0.301766 & 1.961820 & 0.289821 \\
\hline & $\mathrm{H}$ & -1.382817 & 2.451544 & -0.681702 \\
\hline
\end{tabular}

Energy is $\quad-349.512751174$

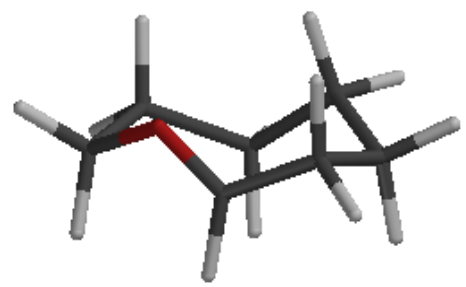

\section{S34}

SPARTAN 'O2 Quantum Mechanics Program:

Job type: Geometry optimization.

Method: RB3LYP

Basis set: $6-31 \mathrm{G}(\mathrm{D})$

Number of shells: 58

Number of basis functions: 146

SCF model:

A restricted hybrid HF-DFT SCF calculation will be performed using Pulay DIIS extrapolation Optimization:

$\begin{array}{rc}\text { Step } & \text { Energy } \\ 1 & -349.5092633 \\ 2 & -349.5116333 \\ 3 & -349.5119159 \\ 4 & -349.5119518 \\ 5 & -349.5119546\end{array}$

$\begin{array}{rr}\text { Max Grad. } & \text { Max Dist. } \\ 0.022124 & 0.088228 \\ 0.003925 & 0.090441 \\ 0.001115 & 0.017085 \\ 0.000665 & 0.004758 \\ 0.000102 & 0.002646\end{array}$




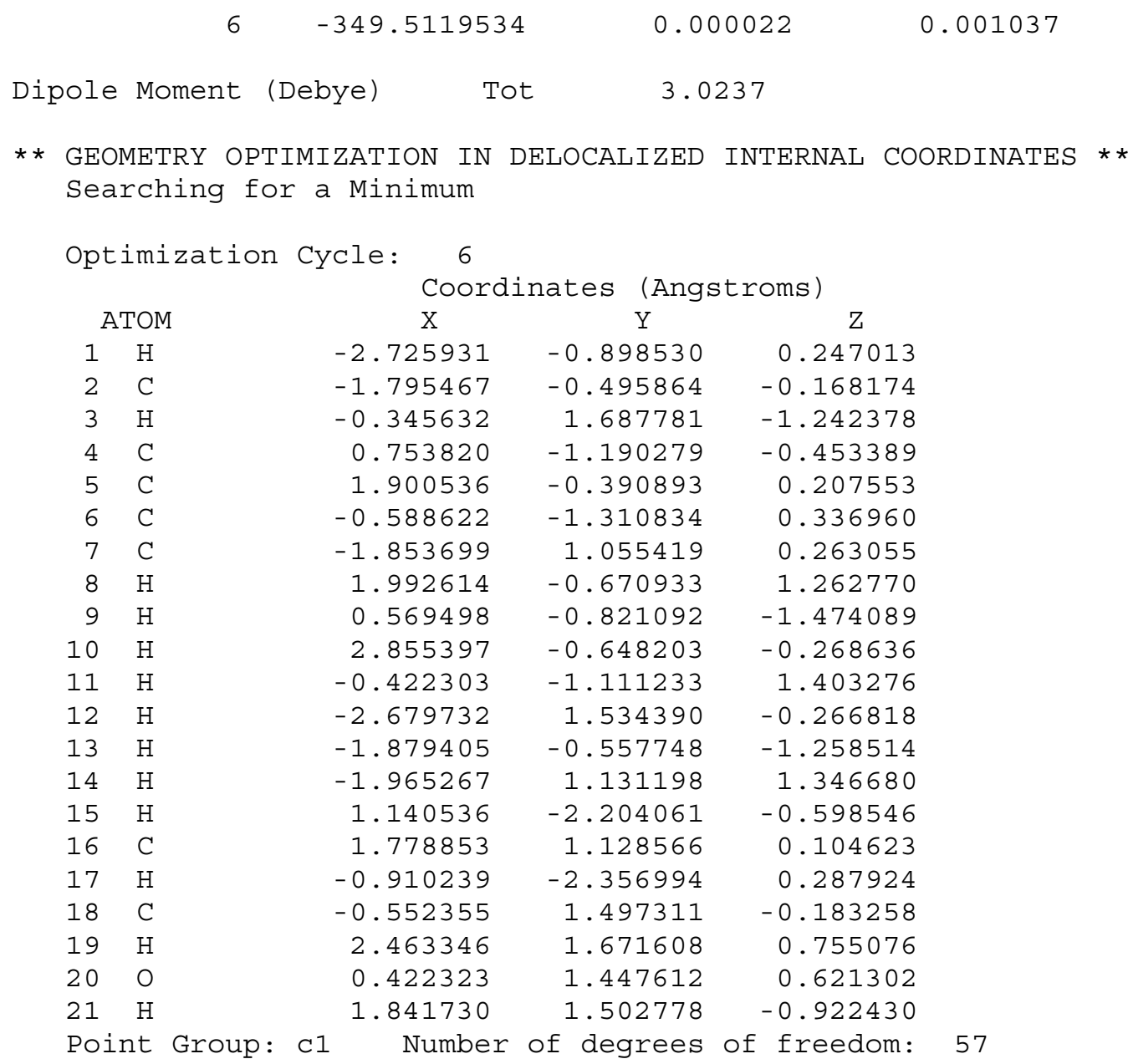

Energy is $\quad-349.511953393$

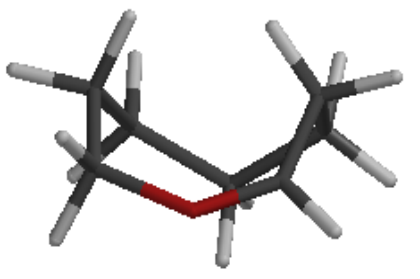

S35

SPARTAN 'O2 Quantum Mechanics Program:

Job type: Geometry optimization.

Method: RB3LYP

Basis set: $6-31 G(D)$

Number of shells: 58

Number of basis functions: 146

SCF model :

A restricted hybrid HF-DFT SCF calculation will be performed using Pulay DIIS extrapolation 


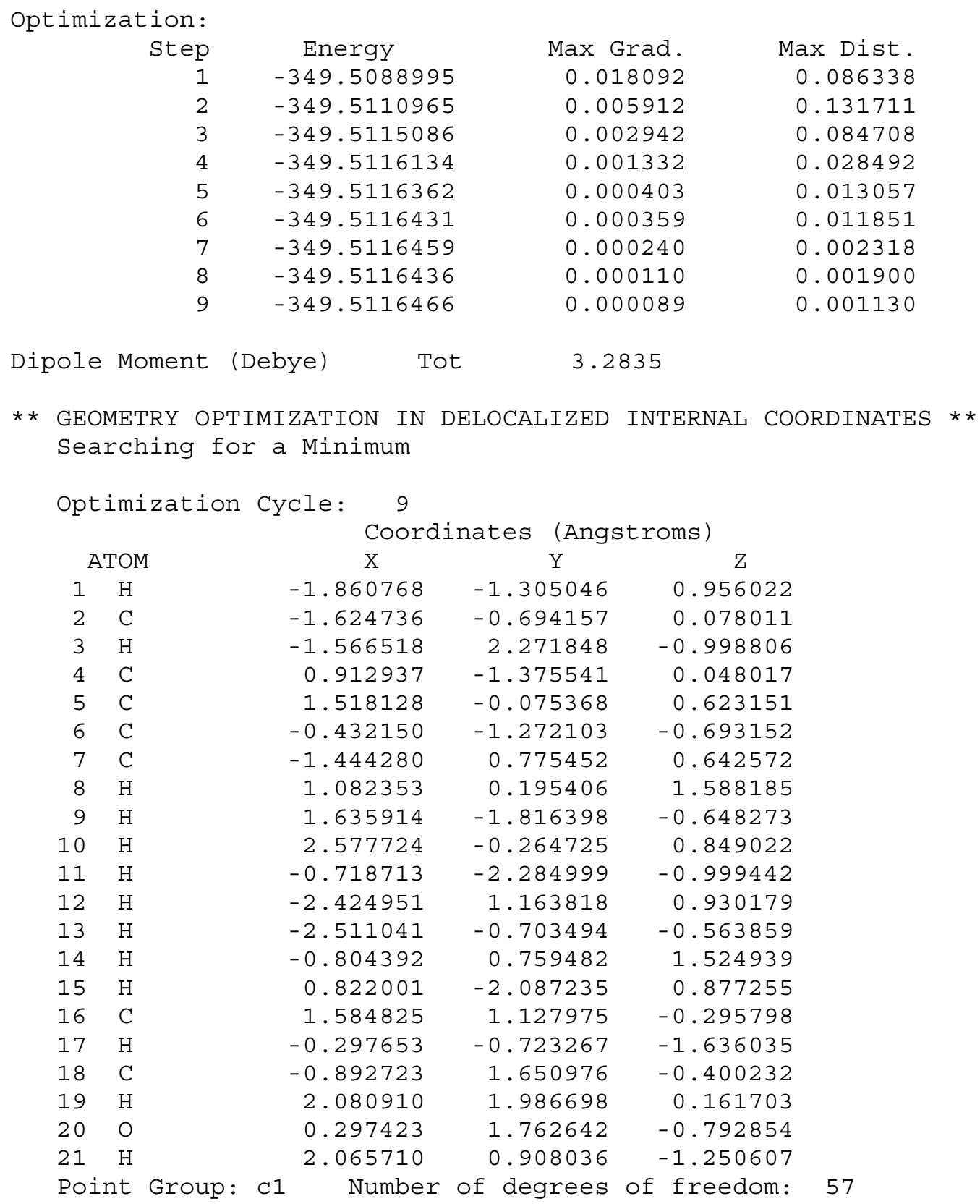

Energy is $\quad-349.511646641$ 
- 4-Methyl Substituted Oxocarbenium Ion

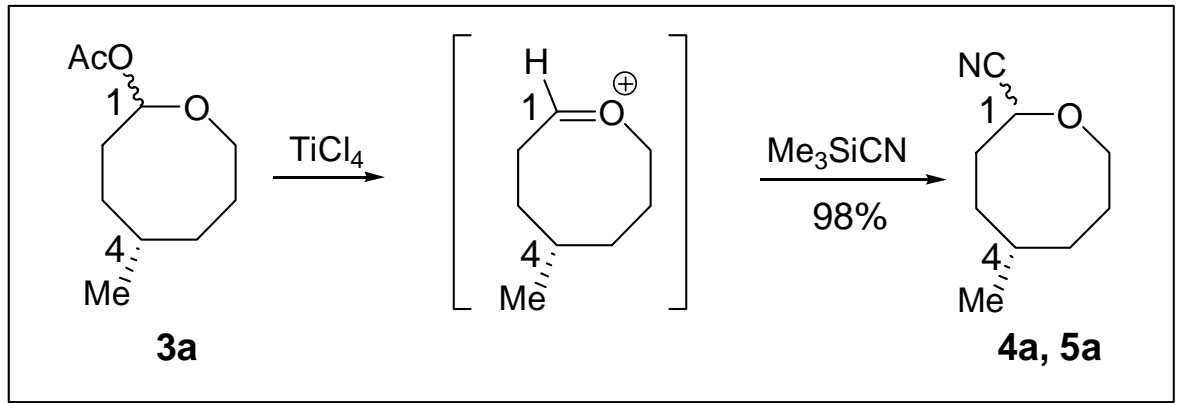

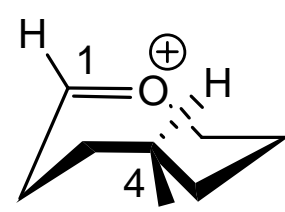

Me

6

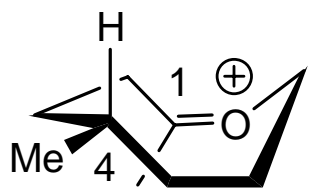

$\mathrm{H}$ 7

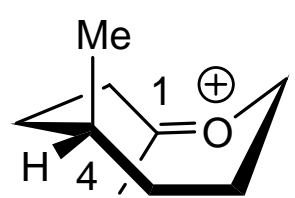

$\mathrm{H}$

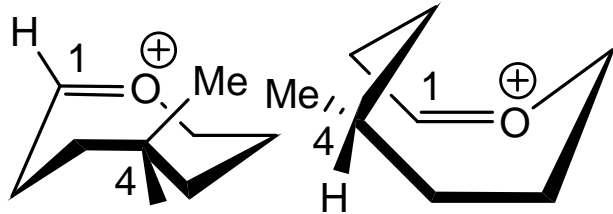

$\mathrm{H}$

$\mathbf{S 3 7}$

S38

\begin{tabular}{|ccc|}
\hline Cation & $\mathrm{E}_{\mathrm{rel}}(\mathrm{kcal} / \mathrm{mol})$ & Resulting Product \\
\hline \hline $\mathbf{6}$ & 0 & 1,4 -cis \\
7 & 0.05 & $1,4-$ trans \\
S36 & 1.7 & 1,4 -cis \\
S37 & 2.0 & $1,4-$ trans \\
S38 & 2.4 & 1,4 -trans \\
\hline
\end{tabular}

The energy differences among these conformers suggest that nucleophilic attack should provide approximately a 1:1 ratio of diastereomers at $273 \mathrm{~K}$ (B3LYP/6-31G*).

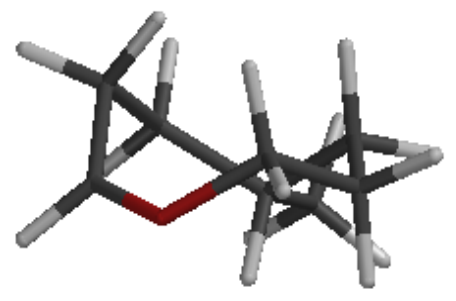

6

SPARTAN 'O2 Quantum Mechanics Program:

Job type: Geometry optimization.

Method: RB3LYP

Basis set: $6-31 \mathrm{G}(\mathrm{D})$

Number of shells: 66 
Number of basis functions: 165

SCF model:

A restricted hybrid $\mathrm{HF}-\mathrm{DFT}$ SCF calculation will be performed using Pulay DIIS extrapolation

Optimization:

$\begin{array}{rc}\text { Step } & \text { Energy } \\ 1 & -388.8302483 \\ 2 & -388.8327798 \\ 3 & -388.8330178 \\ 4 & -388.8330542 \\ 5 & -388.8330606 \\ 6 & -388.8330640\end{array}$

$$
\begin{array}{r}
\text { Max Grad. } \\
0.018577 \\
0.003904 \\
0.001540 \\
0.000679 \\
0.000181 \\
0.000076
\end{array}
$$$$
\text { Max Dist. }
$$$$
0.061514
$$$$
0.030498
$$$$
0.012826
$$$$
0.010259
$$$$
0.003970
$$

0.001161

Dipole Moment (Debye) Tot 4.8664

* * GEOMETRY OPTIMIZATION IN DELOCALIZED INTERNAL COORDINATES ** searching for a Minimum

Optimization Cycle: 6

\begin{tabular}{rrrrr}
\multicolumn{2}{c}{ ATOM } & \multicolumn{3}{c}{ Coordinates (Angstroms) } \\
1 & $\mathrm{H}$ & $\mathrm{X}$ & $\mathrm{Y}$ & \multicolumn{1}{c}{$\mathrm{Z}$} \\
2 & $\mathrm{C}$ & -0.146130 & -0.916793 & -1.545114 \\
3 & $\mathrm{H}$ & -0.262701 & -1.220116 & -0.494850 \\
4 & $\mathrm{C}$ & 3.185601 & -1.059064 & 0.388236 \\
5 & $\mathrm{C}$ & -0.908907 & 1.284703 & -0.215011 \\
6 & $\mathrm{C}$ & 0.571035 & 1.772187 & -0.510455 \\
7 & $\mathrm{C}$ & -1.078448 & -0.160890 & 0.293395 \\
8 & $\mathrm{H}$ & 1.102363 & -1.622868 & 0.100653 \\
9 & $\mathrm{H}$ & 0.538041 & 2.845555 & -0.721371 \\
10 & $\mathrm{C}$ & -1.373154 & 1.983127 & 0.488899 \\
11 & $\mathrm{C}$ & 1.373589 & 1.544041 & 0.687741 \\
12 & $\mathrm{C}$ & -2.582135 & -0.495028 & 0.268533 \\
13 & $\mathrm{H}$ & 2.254969 & -0.635612 & 0.012469 \\
14 & $\mathrm{H}$ & -0.851468 & -2.142722 & -0.528583 \\
15 & $\mathrm{H}$ & 0.984355 & -1.931037 & 1.146792 \\
16 & $\mathrm{H}$ & -1.423936 & 1.412291 & -1.174645 \\
17 & $\mathrm{H}$ & 0.962824 & 1.240448 & -1.379518 \\
18 & $\mathrm{H}$ & -0.758540 & -0.198933 & 1.346213 \\
19 & $\mathrm{H}$ & 1.471520 & -2.509585 & -0.432320 \\
20 & $\mathrm{H}$ & 1.360165 & 2.262535 & 1.512060 \\
21 & $\mathrm{O}$ & 2.413870 & -0.221827 & -0.985073 \\
22 & $\mathrm{H}$ & 2.063049 & 0.522348 & 0.954366 \\
23 & $\mathrm{H}$ & -2.954875 & -0.556505 & -0.760845 \\
24 & $\mathrm{H}$ & -3.171218 & 0.262601 & 0.796468 \\
$\mathrm{P}$ & -2.769870 & -1.458858 & 0.751960
\end{tabular}

Point Group: c1 Number of degrees of freedom: 


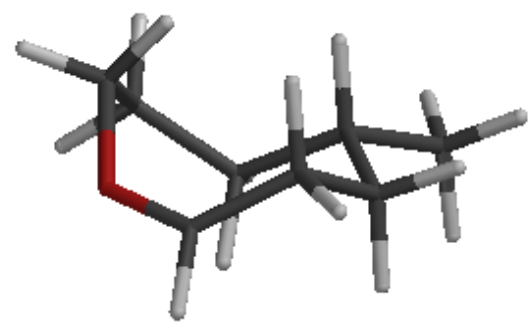

7

SPARTAN 'O2 Quantum Mechanics Program:

Job type: Geometry optimization.

Method: RB3LYP

Basis set: $6-31 \mathrm{G}(\mathrm{D})$

Number of shells: 66

Number of basis functions: 165

SCF model :

A restricted hybrid HF-DFT SCF calculation will be performed using Pulay DIIS extrapolation

Optimization:

$\begin{array}{rc}\text { Step } & \text { Energy } \\ 1 & -388.8301880 \\ 2 & -388.8327810 \\ 3 & -388.8329823 \\ 4 & -388.8329953 \\ 5 & -388.8329998 \\ 6 & -388.8329992\end{array}$

Max Grad.

0.020505

0.003591

0.000805

0.000267

0.000079

0.000023
Max Dist.

0.044104

0.032581

0.006853

0.004316

0.001280

0.001150

Dipole Moment (Debye) Tot 4.8193

* * GEOMETRY OPTIMIZATION IN DELOCALIZED INTERNAL COORDINATES ** Searching for a Minimum

Optimization Cycle: 6 Coordinates (Angstroms)

\begin{tabular}{|c|c|c|c|}
\hline ATOM & $\mathrm{X}$ & $\mathrm{Y}$ & $\mathrm{Z}$ \\
\hline $\mathrm{H}$ & -0.088532 & -0.665992 & -1.592674 \\
\hline C & -0.319860 & -1.130534 & -0.622787 \\
\hline $\mathrm{H}$ & 1.680887 & -0.286913 & 1.416559 \\
\hline C & -0.764959 & 1.349606 & -0.046508 \\
\hline C & 0.696707 & 1.845783 & 0.288287 \\
\hline C & -1.089619 & -0.124277 & 0.272016 \\
\hline C & 0.952585 & -1.771015 & -0.036883 \\
\hline $\mathrm{H}$ & 0.923001 & 1.605767 & 1.332193 \\
\hline $\mathrm{H}$ & -1.410792 & 2.006827 & 0.544534 \\
\hline C & 1.710805 & 1.298106 & -0.623697 \\
\hline C & -2.610667 & -0.320030 & 0.120781 \\
\hline C & 2.001492 & -0.816912 & 0.519894 \\
\hline $\mathrm{H}$ & -0.982708 & -1.965833 & -0.873024 \\
\hline $\mathrm{H}$ & 0.692862 & -2.426014 & 0.805907 \\
\hline $\mathrm{H}$ & -0.981947 & 1.562868 & -1.100127 \\
\hline $\mathrm{H}$ & 0.716085 & 2.933630 & 0.168377 \\
\hline $\mathrm{H}$ & -0.839813 & -0.313317 & 1.327269 \\
\hline
\end{tabular}




$\begin{array}{llrrr}18 & \mathrm{H} & 1.417171 & -2.409989 & -0.795310 \\ 19 & \mathrm{H} & 2.006584 & 1.853543 & -1.517543 \\ 20 & \mathrm{H} & 2.962925 & -1.298932 & 0.693528 \\ 21 & \mathrm{O} & 2.323121 & 0.198606 & -0.525948 \\ 22 & \mathrm{H} & -2.926686 & -0.171184 & -0.918683 \\ 23 & \mathrm{H} & -3.170716 & 0.380617 & 0.748602 \\ 24 & \mathrm{H} & -2.897926 & -1.334411 & 0.415238 \\ \text { Point Group: } \mathrm{Cl} \text { Number of degrees of freedom: }\end{array}$

Energy is $\quad-388.832999175$

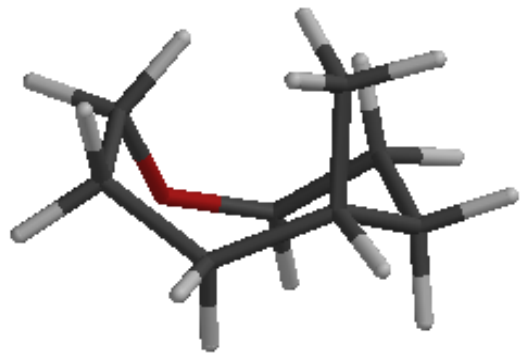

S36

SPARTAN 'O2 Quantum Mechanics Program:

Job type: Geometry optimization.

Method: RB3LYP

Basis set: $6-31 \mathrm{G}(\mathrm{D})$

Number of shells: 66

Number of basis functions: 165

SCF model :

A restricted hybrid HF-DFT SCF calculation will be performed using Pulay DIIS extrapolation

Optimization:

$\begin{array}{rcrr}\text { Step } & \text { Energy } & \text { Max Grad. } & \text { Max Dist. } \\ 1 & -388.8275162 & 0.014958 & 0.072203 \\ 2 & -388.8301512 & 0.003608 & 0.133481 \\ 3 & -388.8303204 & 0.004475 & 0.095261 \\ 4 & -388.8304182 & 0.000707 & 0.018785 \\ 5 & -388.8304355 & 0.000391 & 0.003135 \\ 6 & -388.8304383 & 0.000208 & 0.003072 \\ 7 & -388.8304400 & 0.000101 & 0.002481 \\ 8 & -388.8304385 & 0.000030 & 0.000659\end{array}$

Dipole Moment (Debye) Tot 4.1308

** GEOMETRY OPTIMIZATION IN DELOCALIZED INTERNAL COORDINATES ** Searching for a Minimum

Optimization Cycle: 8 Coordinates (Angstroms)

\begin{tabular}{rrrrr}
\multicolumn{2}{c}{ ATOM } & \multicolumn{1}{c}{ X } & \multicolumn{1}{c}{ Y } & \multicolumn{1}{c}{ Z } \\
1 & $\mathrm{H}$ & -0.681095 & 1.880827 & 1.592442 \\
2 & $\mathrm{C}$ & -0.527173 & 0.907717 & 1.112106 \\
3 & $\mathrm{H}$ & -2.815987 & -0.750702 & -1.032676 \\
4 & $\mathrm{C}$ & 1.584805 & -0.472508 & 0.477012
\end{tabular}




$\begin{array}{rrrrr}5 & \mathrm{C} & 0.948281 & -1.594860 & -0.441629 \\ 6 & \mathrm{C} & 0.892423 & 0.907493 & 0.486268 \\ 7 & \mathrm{C} & -1.765307 & 0.707721 & 0.213024 \\ 8 & \mathrm{H} & 1.675136 & -2.408113 & -0.528402 \\ 9 & \mathrm{H} & 1.662562 & -0.856883 & 1.500692 \\ 10 & \mathrm{C} & -0.253511 & -2.150564 & 0.189963 \\ 11 & \mathrm{C} & 0.988613 & 1.642380 & -0.859424 \\ 12 & \mathrm{C} & -1.807436 & -0.519720 & -0.691107 \\ 13 & \mathrm{H} & -0.556946 & 0.184826 & 1.940111 \\ 14 & \mathrm{H} & -2.652523 & 0.705552 & 0.855126 \\ 15 & \mathrm{H} & 2.609666 & -0.366764 & 0.106085 \\ 16 & \mathrm{H} & 0.753121 & -1.184952 & -1.435461 \\ 17 & \mathrm{H} & 1.511495 & 1.478715 & 1.192133 \\ 18 & \mathrm{H} & -1.884303 & 1.558697 & -0.469785 \\ 19 & \mathrm{H} & -0.171364 & -3.003953 & 0.868081 \\ 20 & \mathrm{H} & -1.132451 & -0.463860 & -1.543865 \\ 21 & \mathrm{O} & -1.442131 & -1.735641 & 0.093311 \\ 22 & \mathrm{H} & 0.444076 & 1.145055 & -1.671500 \\ 23 & \mathrm{H} & 2.032882 & 1.731815 & -1.176691 \\ 24 & \mathrm{H} & 0.587168 & 2.657721 & -0.775815 \\ \text { Point Group : C1 } & \text { Number } & \text { of degrees } & \text { of } & \text { freedom: }\end{array}$

Energy is $\quad-388.830438484$

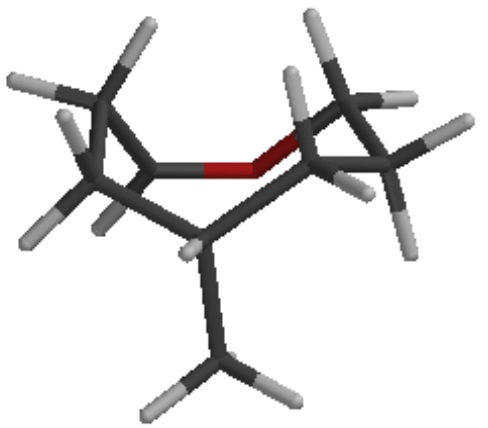

S37

SPARTAN 'O2 Quantum Mechanics Program:

Job type: Geometry optimization.

Method: RB3LYP

Basis set: $6-31 \mathrm{G}(\mathrm{D})$

Number of shells: 66

Number of basis functions: 165

SCF model :

A restricted hybrid HF-DFT SCF calculation will be performed using Pulay DIIS extrapolation

Optimization:

$\begin{array}{rc}\text { Step } & \text { Energy } \\ 1 & -388.8270498 \\ 2 & -388.8295981 \\ 3 & -388.8298471 \\ 4 & -388.8299017 \\ 5 & -388.8299270 \\ 6 & -388.8299295\end{array}$

Max Grad.
0.019496
0.005265
0.003012
0.001044
0.000331
0.000188

Max Dist. 0.061425

0.111953

0.050618

0.027474

0.011580

0.006138 


$$
\begin{array}{llll}
7 & -388.8299301 & 0.000055 & 0.002634
\end{array}
$$

Dipole Moment (Debye) Tot 3.9048

* * GEOMETRY OPTIMIZATION IN DELOCALIZED INTERNAL COORDINATES ** searching for a Minimum

Optimization Cycle: 7

\begin{tabular}{|c|c|c|c|}
\hline \multirow[b]{2}{*}{ ATOM } & \multicolumn{3}{|c|}{ Coordinates (Angstroms) } \\
\hline & $\mathrm{X}$ & $\mathrm{Y}$ & $\mathrm{Z}$ \\
\hline $1 \quad \mathrm{H}$ & -0.448145 & 2.190124 & 1.228067 \\
\hline $\mathrm{C}$ & -0.405379 & 1.126009 & 0.969401 \\
\hline $\mathrm{H}$ & -2.080874 & -1.192497 & 0.678450 \\
\hline $\mathrm{C}$ & 1.558089 & -0.566079 & 0.627729 \\
\hline $\mathrm{C}$ & 0.571925 & -1.782604 & 0.382220 \\
\hline $\mathrm{C}$ & 1.011901 & 0.859343 & 0.393693 \\
\hline $\mathrm{C}$ & -1.642749 & 0.880718 & 0.075944 \\
\hline $\mathrm{H}$ & -0.177820 & -1.804064 & 1.176162 \\
\hline $\mathrm{H}$ & 1.853858 & -0.694170 & 1.674290 \\
\hline $\mathrm{C}$ & -0.045928 & -1.706065 & -0.938755 \\
\hline $\mathrm{C}$ & 1.181828 & 1.329912 & -1.060450 \\
\hline $\mathrm{C}$ & -2.067435 & -0.552738 & -0.205780 \\
\hline $\mathrm{H}$ & -0.529491 & 0.593975 & 1.923233 \\
\hline $\mathrm{H}$ & -2.512332 & 1.320081 & 0.583287 \\
\hline $\mathrm{H}$ & 2.458358 & -0.720895 & 0.023982 \\
\hline $\mathrm{H}$ & 1.169632 & -2.699181 & 0.429244 \\
\hline $\mathrm{H}$ & 1.684274 & 1.487878 & 0.993161 \\
\hline $\mathrm{H}$ & -1.556959 & 1.417089 & -0.875203 \\
\hline $\mathrm{H}$ & 0.475076 & -2.079283 & -1.824124 \\
\hline $\mathrm{H}$ & -3.028773 & -0.603791 & -0.715092 \\
\hline O & -1.164968 & -1.194183 & -1.219073 \\
\hline $\mathrm{H}$ & 0.633188 & 0.718808 & -1.789293 \\
\hline $\mathrm{H}$ & 2.237465 & 1.312819 & -1.350792 \\
\hline $\mathrm{H}$ & 0.825258 & 2.358791 & -1.180299 \\
\hline
\end{tabular}

Energy is $\quad-388.829930130$

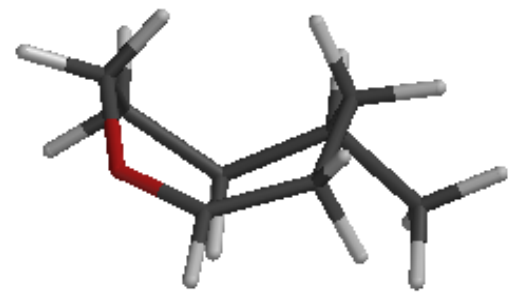

S38

SPARTAN 'O2 Quantum Mechanics Program:

Job type: Geometry optimization.

Method: RB3LYP

Basis set: $6-31 G(D)$

Number of shells: 66

Number of basis functions: 165

SCF model : 
A restricted hybrid HF-DFT SCF calculation will be performed using Pulay DIIS extrapolation

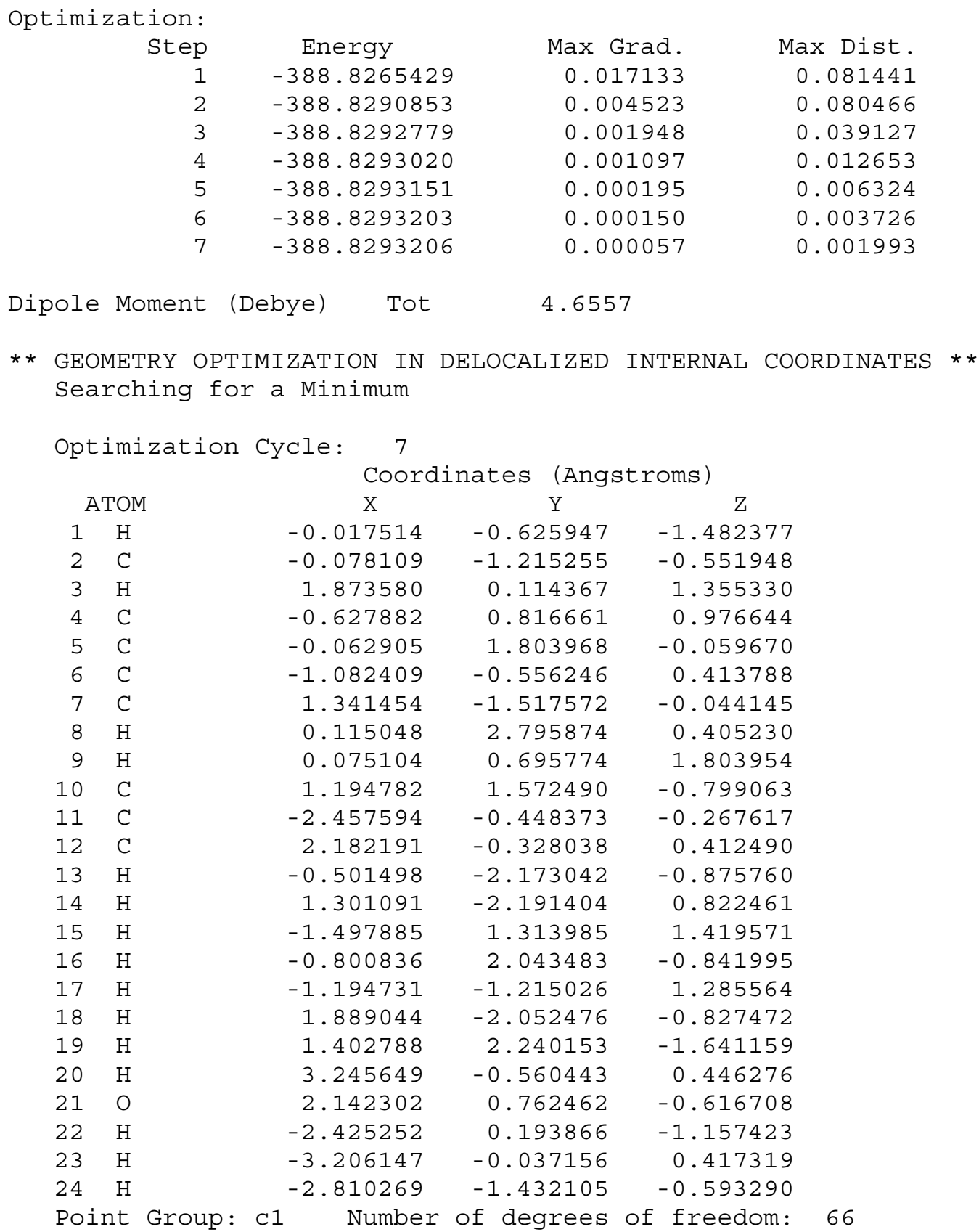

Energy is $\quad-388.829320598$ 


\section{- 4-Alkoxy Substituted Oxocarbenium Ion}

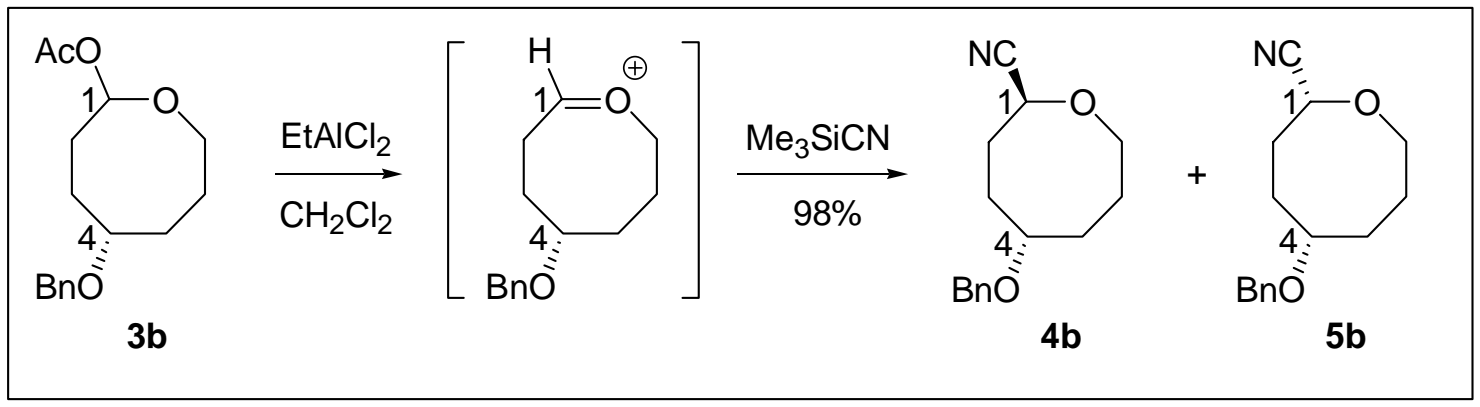

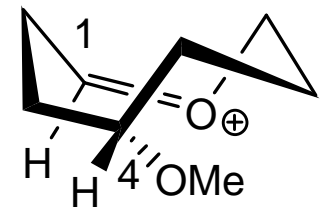

8

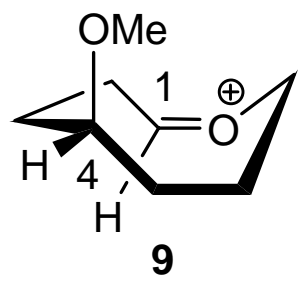

9

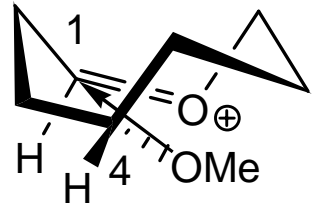

S39 (bridged)

\begin{tabular}{|ccc|}
\hline Cation & $\mathrm{E}_{\text {rel }}(\mathrm{kcal} / \mathrm{mol})$ & Resulting Product \\
\hline $\mathbf{8}$ & 0 & $1,4-$ trans \\
$\mathbf{9}$ & 2.5 & $1,4-$ cis \\
s39 & -5.3 & $1,4-$ trans \\
\hline
\end{tabular}

The energy difference between these conformers suggests that nucleophilic attack should provide approximately a $98: 2$ trans : cis ratio of diastereomers at $273 \mathrm{~K}$ (B3LYP/6-31G*).

Further optimization of the conformers obtained from the systematic conformational search often yielded inconsistent results. The systematic conformational search always provided the same list of conformers. The PM3 geometries of those respective conformers were identical. Conformer 8 was also determined to be the equilibrium conformer (MMFF energy $=16.9915$ $\mathrm{kcal} / \mathrm{mol}$ ) of this cation at MMFF level of theory, and remained the lowest energy conformer $($ PM3 energy $=96.4644 \mathrm{kcal} / \mathrm{mol})$ after geometry optimization using PM3. Upon further analysis of the geometries using density functional theory (B3LYP/6-31G*), however, a new conformer, S39, formed from what was believed to be the lowest energy conformer (the global minimum), 8. Conformer S39 resembles 8, except that the methoxy substituent has formed a 
partial bond with the carbocationic carbon, yielding a trivalent oxonium ion. The geometry of conformer 8 could be optimized using B3LYP/6-31G* if the distance between the methoxy oxygen atom and the carbocationic carbon was constrained to $2.78 \AA$, the distance between these atoms in the PM3 geometry.

We sought to determine if $\mathbf{S 3 9}$ was the global minimum of this intermediate. Single point energy calculations (B3LYP/6-31G*) of B3LYP/6-31G* optimized geometries indicate that $\mathbf{9}$ and S39 are both minima because no imaginary frequencies are present. Comparison of the energies of $\mathbf{9}$ and $\mathbf{S 3 9}$ strongly suggests that $\mathbf{S 3 9}$ is the global minimum. While we do not dispute that conformer $\mathbf{S 3 9}$ exists and is quite possibly the global minimum, our experimental results suggest that it is likely not a reactive conformer.

Based on our calculations, the energy difference between the lowest energy conformation (S39) leading to the major product $\mathbf{4 b}$ and conformer $\mathbf{9}$ which provides the minor diastereomer $\mathbf{5 b}$ is $7.8 \mathrm{kcal} / \mathrm{mol}$. If we assume that the respective transition state barriers leading to product are equal, then the reaction selectivity ought to reflect the energy difference between the conformers $\left(7.8 \mathrm{kcal} / \mathrm{mol} \Rightarrow>10^{5}: 1\right.$, trans : cis). Because the $96: 4$ trans : cis product ratio we observed upon nucleophilic substitution better reflects the energy difference between conformers $\mathbf{8}$ and $\mathbf{9}$, we do not believe $\mathbf{S 3 9}$ is a reactive conformer.

From experimental and theoretical efforts, oxocarbenium ions have been shown to possess $\mathrm{C}=\mathrm{O}^{+}$bond lengths of approximately $1.26 \AA$, indicative of the double bond character believed to exist for these resonance stabilized carbocations. The stabilization offered by the remote methoxy substituent causes the $\mathrm{C}=\mathrm{O}^{+}$bond in $\mathbf{S 3 9}$ to lengthen to $1.34 \AA$. Some degree of bond lengthening is also observed for anti-Bredt olefins, which this bridging bicyclic carbocation resembles. Anti-Bredt olefins are typically strained, but it is possible that the stabilization 
offered by the remote substituent in $\mathbf{S 3 9}$ compensates for the strain introduced upon close approach of the remote methoxy substituent.

Furthermore, the increased partial positive charge on the benzyloxy oxygen atom in $\mathbf{S 3 9}$ should make the benzyl group susceptible to removal by nucleophilic attack. No products arising from cleavage of the benzyl ether were observed under the reaction conditions examined in this study. The presence of $\mathbf{S 3 9}$ as a low energy conformer seems to reinforce our hypothesis that a remote alkoxy substituent can control the conformation of a medium ring oxocarbenium ion. The requisite energy and coordinate data for $\mathbf{S 3 9}$ appears after the data provided for conformer 9.

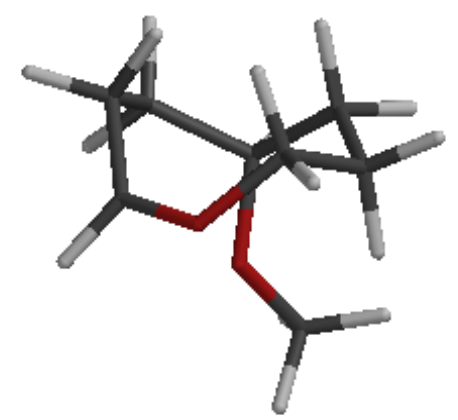

8
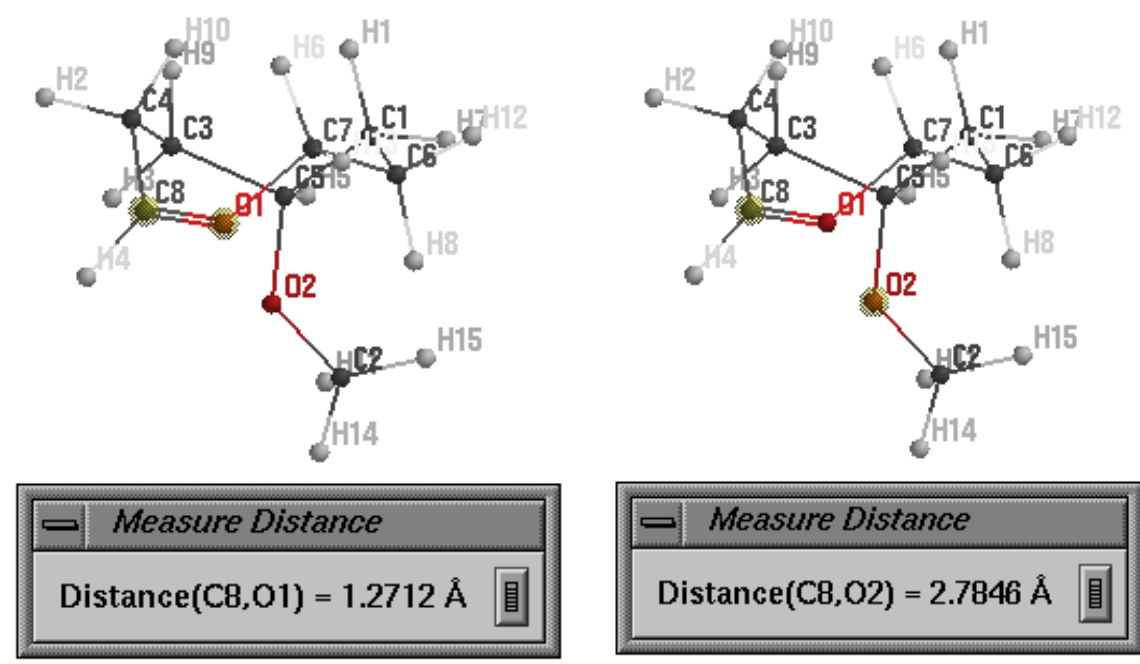

SPARTAN 'O2 Quantum Mechanics Program:

Job type: Geometry optimization.

Method: RB3LYP 
Basis set: $6-31 \mathrm{G}(\mathrm{D})$

Number of shells: 70

Number of basis functions: 180

$\mathrm{SCF}$ model:

A restricted hybrid HF-DFT SCF calculation will be performed using Pulay DIIS extrapolation

Optimization:

$\begin{array}{rcrrr}\text { Step } & \text { Energy } & \text { Max Grad. } & \text { Max Dist. } & \\ 1 & -464.0346521 & 0.020927 & 0.089487 & 2 \\ 2 & -464.0419718 & 0.002985 & 0.126400 & 2 \\ 3 & -464.0416690 & 0.006914 & 0.111043 & 1 \\ 4 & -464.0423639 & 0.000916 & 0.043408 & 1 \\ 5 & -464.0424205 & 0.000253 & 0.023468 & \\ 6 & -464.0424287 & 0.000090 & 0.006180 & \\ 7 & -464.0424310 & 0.000030 & 0.002111 & \\ 8 & -464.0424318 & 0.000011 & 0.000386\end{array}$

Dipole Moment (Debye) Tot 3.5905

* * CONSTRAINED OPTIMIZATION IN DELOCALIZED INTERNAL COORDINATES ** searching for a Minimum

Optimization Cycle: 8

\begin{tabular}{|c|c|c|c|}
\hline \multirow[b]{2}{*}{ ATOM } & \multicolumn{3}{|c|}{ Coordinates (Angstroms) } \\
\hline & $\mathrm{X}$ & $\mathrm{Y}$ & $\mathrm{Z}$ \\
\hline $\mathrm{H}$ & 0.506845 & 2.046213 & -1.665056 \\
\hline $\mathrm{C}$ & 0.242314 & 1.743771 & -0.646916 \\
\hline $\mathrm{H}$ & 0.324043 & -2.726624 & -0.794549 \\
\hline $\mathrm{C}$ & 1.410274 & 0.697613 & 1.338965 \\
\hline $\mathrm{H}$ & -0.552160 & -1.976034 & 0.523234 \\
\hline $\mathrm{C}$ & 1.606414 & 1.382655 & 0.053275 \\
\hline $\mathrm{C}$ & -0.806390 & 0.627829 & -0.673351 \\
\hline O & 1.426688 & -0.549133 & 1.529941 \\
\hline $\mathrm{H}$ & 1.237628 & 1.261067 & 2.257627 \\
\hline $\mathrm{C}$ & 1.540155 & -1.556274 & 0.430260 \\
\hline $\mathrm{H}$ & 2.210215 & 0.771853 & -0.622063 \\
\hline $\mathrm{C}$ & -0.322378 & -0.729488 & -1.254480 \\
\hline $\mathrm{H}$ & -0.198471 & 2.608712 & -0.144231 \\
\hline O & -1.284520 & 0.514786 & 0.661720 \\
\hline $\mathrm{H}$ & 1.863598 & -2.439311 & 0.979662 \\
\hline $\mathrm{H}$ & 2.335904 & -1.234162 & -0.244707 \\
\hline $\mathrm{H}$ & 2.138580 & 2.319960 & 0.248857 \\
\hline $\mathrm{H}$ & -1.617542 & 1.001547 & -1.316570 \\
\hline $\mathrm{H}$ & 0.428920 & -0.542923 & -2.033285 \\
\hline $\mathrm{H}$ & -1.164737 & -1.201131 & -1.771776 \\
\hline $\mathrm{C}$ & 0.196335 & -1.781454 & -0.250631 \\
\hline $\mathrm{C}$ & -2.620618 & 0.028983 & 0.806945 \\
\hline $\mathrm{H}$ & -2.725145 & -1.005328 & 0.454207 \\
\hline $\mathrm{H}$ & -3.324715 & 0.668860 & 0.259973 \\
\hline $\mathrm{H}$ & -2.851237 & 0.068015 & 1.872950 \\
\hline
\end{tabular}

Point Group: $c 1$ Number of degrees of freedom: 


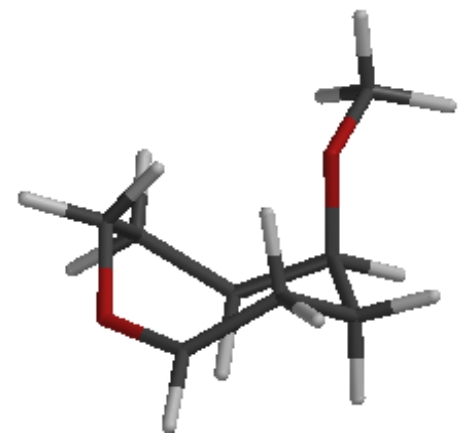

9

SPARTAN 'O2 Quantum Mechanics Program:

Job type: Geometry optimization.

Method: RB3LYP

Basis set: $6-31 \mathrm{G}(\mathrm{D})$

Number of shells: 70

Number of basis functions: 180

SCF model :

A restricted hybrid HF-DFT SCF calculation will be performed using Pulay DIIS extrapolation

Optimization:

$\begin{array}{rc}\text { Step } & \text { Energy } \\ 1 & -464.0325028 \\ 2 & -464.0389129 \\ 3 & -464.0386956 \\ 4 & -464.0394329 \\ 5 & -464.0396051 \\ 6 & -464.0396497 \\ 7 & -464.0396641 \\ 8 & -464.0396724 \\ 9 & -464.0396773 \\ 10 & -464.0396794 \\ 11 & -464.0396802\end{array}$

$$
\begin{array}{r}
\text { Max Grad. } \\
0.015744 \\
0.004462 \\
0.005616 \\
0.002917 \\
0.001718 \\
0.000815 \\
0.000197 \\
0.000319 \\
0.000430 \\
0.000281 \\
0.000091
\end{array}
$$$$
\text { Max Dist. }
$$$$
0.088189
$$$$
0.128283
$$$$
0.128859
$$$$
0.064436
$$

\begin{tabular}{|c|c|c|c|c|}
\hline \multirow{2}{*}{\multicolumn{2}{|c|}{ ATOM }} & \multicolumn{3}{|c|}{ Coordinates (Angstroms) } \\
\hline & & $\mathrm{X}$ & $\mathrm{Y}$ & $\mathrm{Z}$ \\
\hline 1 & $\mathrm{H}$ & 0.940131 & -0.527762 & -1.908739 \\
\hline 2 & $\mathrm{C}$ & 0.254864 & -1.055734 & -1.231502 \\
\hline 3 & $\mathrm{H}$ & 2.661365 & 1.957669 & -0.315213 \\
\hline 4 & $\mathrm{C}$ & -0.422807 & 1.406565 & -0.723846 \\
\hline 5 & $\mathrm{C}$ & 0.571132 & 1.774164 & 0.439423 \\
\hline 6 & $\mathrm{C}$ & -0.850377 & -0.078063 & -0.761088 \\
\hline 7 & $\mathrm{C}$ & 1.047341 & -1.801863 & -0.141919 \\
\hline 8 & $\mathrm{H}$ & 0.165262 & 1.355501 & 1.365589 \\
\hline 9 & $\mathrm{H}$ & -1.298098 & 2.041853 & -0.554755 \\
\hline 10 & $\mathrm{C}$ & 1.936674 & 1.300561 & 0.172923 \\
\hline 11 & $\mathrm{H}$ & -1.664348 & -0.120192 & -1.500790 \\
\hline 12 & $\mathrm{C}$ & 1.617902 & -0.964521 & 0.993254 \\
\hline
\end{tabular}$$
0.025185
$$$$
0.019077
$$$$
0.019278
$$$$
0.020896
$$$$
0.021140
$$$$
0.003220
$$

0.001946

Dipole Moment (Debye) Tot 4.0917

* * GEOMETRY OPTIMIZATION IN DELOCALIZED INTERNAL COORDINATES * * Searching for a Minimum

Optimization Cycle: 11 


$\begin{array}{rrrrr}13 & \mathrm{H} & -0.209469 & -1.832470 & -1.847887 \\ 14 & \mathrm{H} & 0.393076 & -2.524638 & 0.358186 \\ 15 & \mathrm{H} & -0.009148 & 1.699105 & -1.695153 \\ 16 & \mathrm{H} & 0.617314 & 2.864175 & 0.521670 \\ 17 & \mathrm{O} & -1.329804 & -0.512023 & 0.501402 \\ 18 & \mathrm{H} & 1.850013 & -2.372085 & -0.621217 \\ 19 & \mathrm{H} & 2.358562 & -1.502480 & 1.583979 \\ 20 & \mathrm{H} & 0.841498 & -0.542440 & 1.626752 \\ 21 & \mathrm{O} & 2.421585 & 0.163101 & 0.420489 \\ 22 & \mathrm{C} & -2.705659 & -0.227891 & 0.766363 \\ 23 & \mathrm{H} & -3.350474 & -0.670011 & -0.003719 \\ 24 & \mathrm{H} & -2.901554 & 0.851200 & 0.823772 \\ 25 & \mathrm{H} & -2.934982 & -0.681721 & 1.732025 \\ \text { Point Group: } & \mathrm{C} 1 & \text { Number } & \text { of degrees of freedom: }\end{array}$

Energy is $\quad-464.039680219$

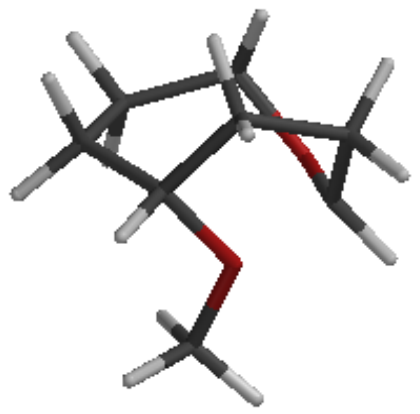

S39

SPARTAN 'O2 Quantum Mechanics Program:

Job type: Geometry optimization.

Method: RB3LYP

Basis set: $6-31 \mathrm{G}(\mathrm{D})$

Number of shells: 70

Number of basis functions: 180

SCF model:

A restricted hybrid HF-DFT SCF calculation will be performed using Pulay DIIS extrapolation

Optimization:

\begin{tabular}{|c|c|c|c|}
\hline Step & Energy & Max Grad. & Max Dist. \\
\hline 1 & -464.0346536 & 0.018043 & 0.097879 \\
\hline 2 & -464.0419811 & 0.007270 & 0.125796 \\
\hline 3 & -464.0431644 & 0.005797 & 0.181394 \\
\hline 4 & -464.0438832 & 0.003480 & 0.119939 \\
\hline 5 & -464.0443776 & 0.002606 & 0.158509 \\
\hline 6 & -464.0447767 & 0.002540 & 0.150348 \\
\hline 7 & -464.0451634 & 0.002425 & 0.145252 \\
\hline 8 & -464.0455395 & 0.002316 & 0.140586 \\
\hline 9 & -464.0460145 & 0.003203 & 0.114159 \\
\hline 10 & -464.0385062 & 0.054222 & 0.104753 \\
\hline 11 & -464.0467427 & 0.004499 & 0.119900 \\
\hline 12 & -464.0475755 & 0.006929 & 0.113347 \\
\hline 13 & -464.0480261 & 0.013569 & 0.091997 \\
\hline 14 & -464.0488539 & 0.004833 & 0.100024 \\
\hline 15 & -464.0488608 & 0.010217 & 0.048498 \\
\hline
\end{tabular}




$\begin{array}{llll}16 & -464.0491264 & 0.003663 & 0.059144 \\ 17 & -464.0492711 & 0.003505 & 0.048855 \\ 18 & -464.0493936 & 0.002192 & 0.120382 \\ 19 & -464.0495274 & 0.004621 & 0.096810 \\ 20 & -464.0498343 & 0.004665 & 0.093454 \\ 21 & -464.0502033 & 0.005250 & 0.094865 \\ 22 & -464.0505136 & 0.004942 & 0.096198 \\ 23 & -464.0507787 & 0.003635 & 0.105888 \\ 24 & -464.0509815 & 0.004105 & 0.093179 \\ 25 & -464.0512670 & 0.004829 & 0.110069 \\ 26 & -464.0514982 & 0.004870 & 0.133012 \\ 27 & -464.0518020 & 0.003731 & 0.104593 \\ 28 & -464.0519477 & 0.001221 & 0.029148 \\ 29 & -464.0519627 & 0.001041 & 0.011449 \\ 30 & -464.0519753 & 0.000391 & 0.009323 \\ 31 & -464.0519794 & 0.000159 & 0.005453 \\ 32 & -464.0519718 & 0.000135 & 0.006069 \\ 33 & -464.0519764 & 0.000093 & 0.001051\end{array}$

Dipole Moment (Debye) Tot 1.5889

* * GEOMETRY OPTIMIZATION IN DELOCALIZED INTERNAL COORDINATES ** searching for a Minimum

Optimization Cycle: 33

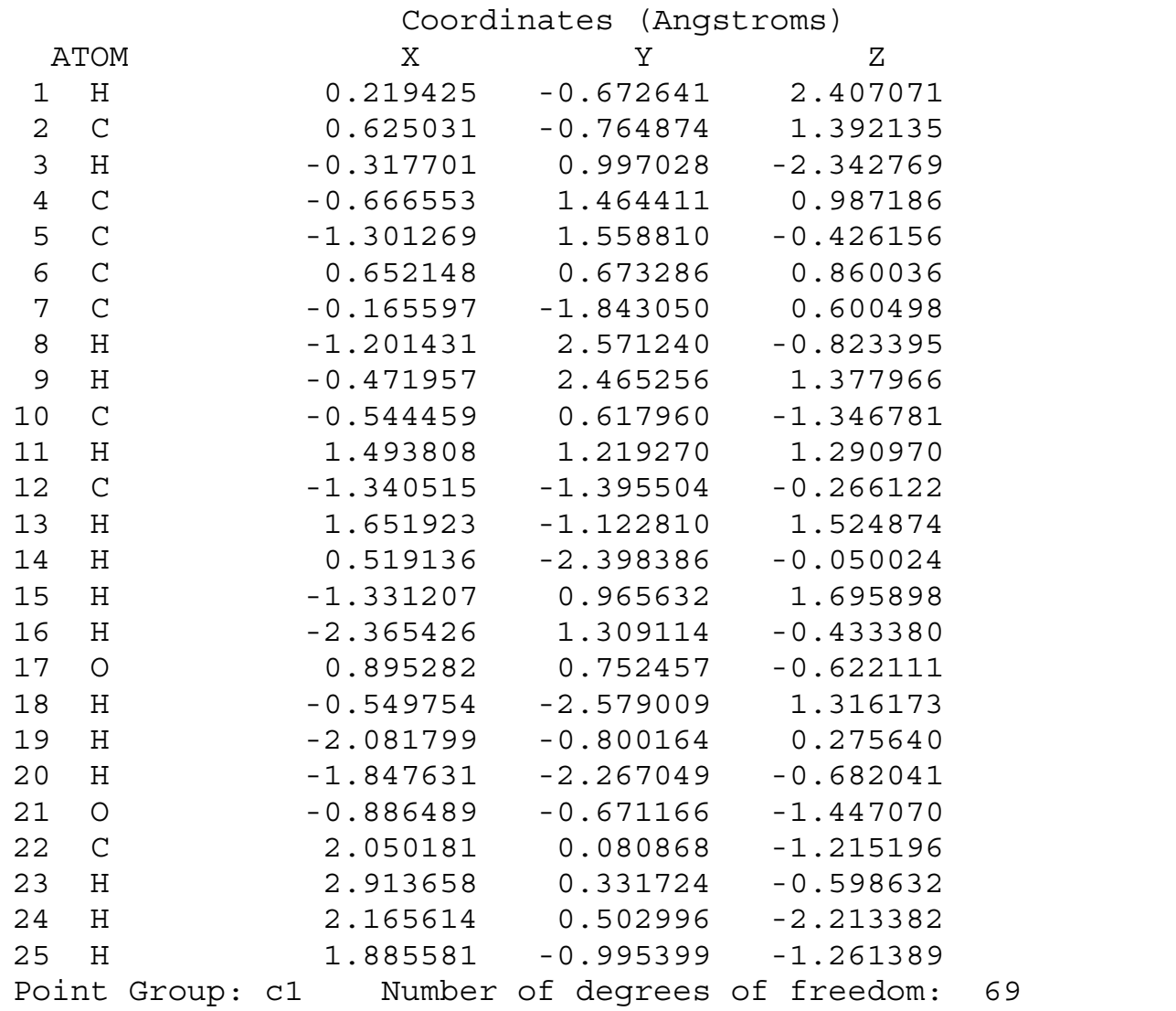




\section{- 5-Methyl Substituted Oxocarbenium Ion}

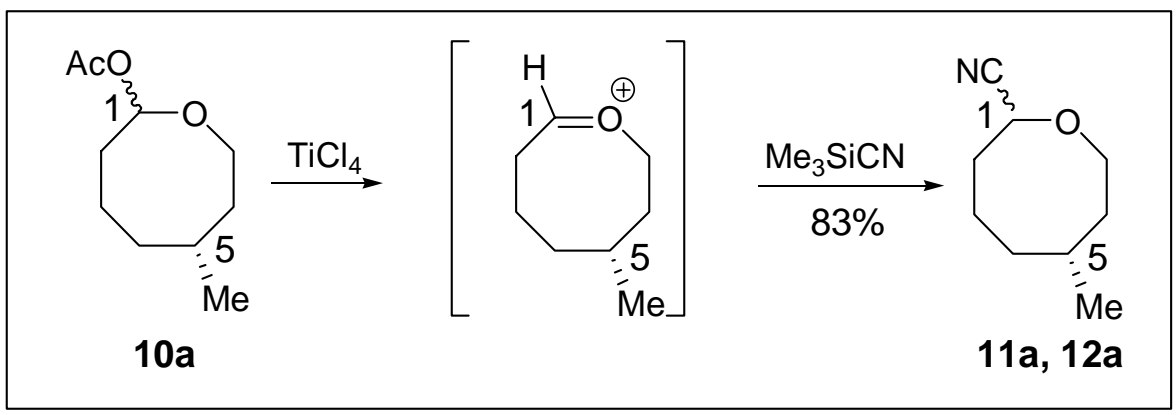

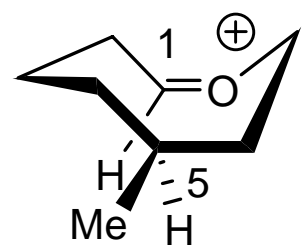

13

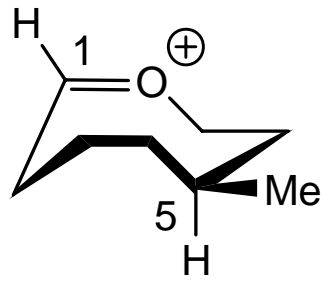

S40

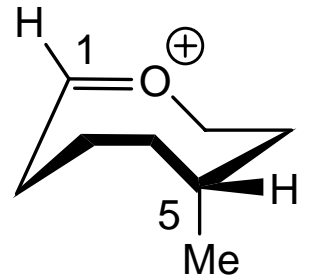

S41

\begin{tabular}{|ccc}
\hline Cation & $\mathrm{E}_{\mathrm{rel}}(\mathrm{kcal} / \mathrm{mol})$ & Resulting Produc \\
\hline $\mathbf{1 3}$ & 0 & 1,5 -cis \\
S40 & 0.3 & 1,5 -trans \\
S41 & 1.9 & 1,5 -cis
\end{tabular}

The energy differences among these conformers suggest that nucleophilic attack should provide approximately a 1:1 ratio of diastereomers at $273 \mathrm{~K}\left(\mathrm{~B} 3 \mathrm{LYP} / 6-31 \mathrm{G}^{*}\right)$.

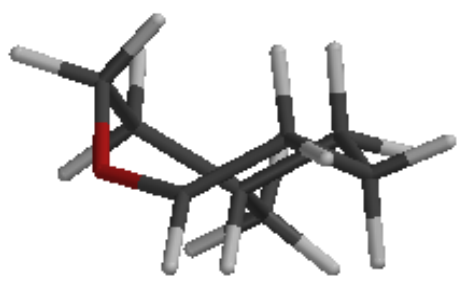

13

SPARTAN 'O2 Quantum Mechanics Program:

Job type: Geometry optimization.

Method: RB3LYP

Basis set: $6-31 \mathrm{G}(\mathrm{D})$

Number of shells: 66

Number of basis functions: 165 
SCF model:

A restricted hybrid HF-DFT SCF calculation will be performed using Pulay DIIS extrapolation

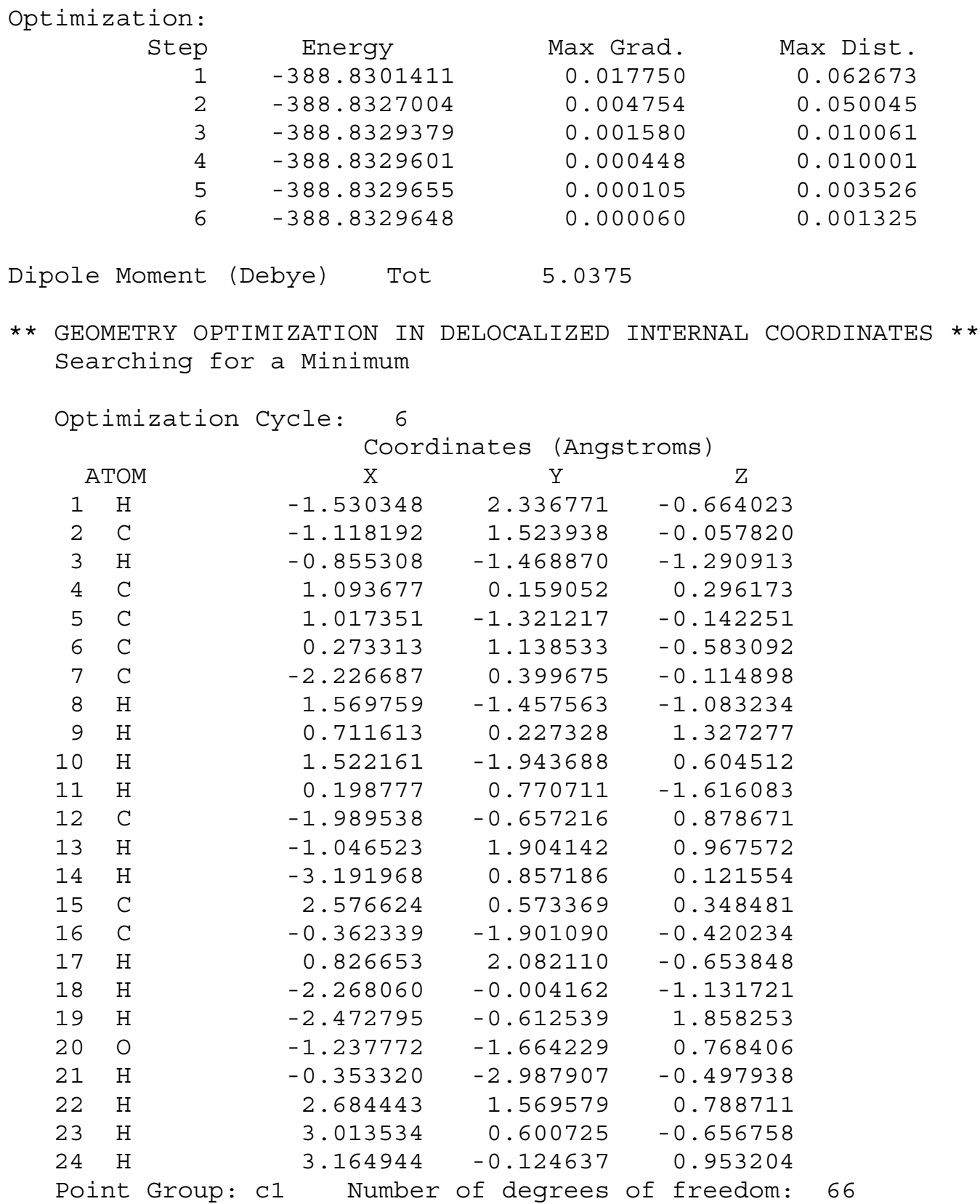




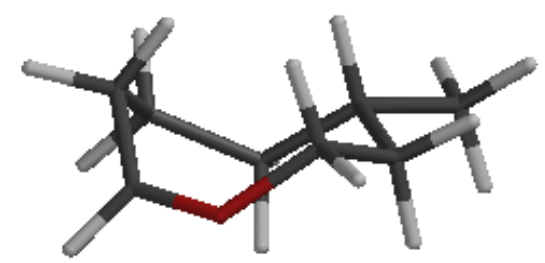

S40

SPARTAN 'O2 Quantum Mechanics Program:

Job type: Geometry optimization.

Method: RB3LYP

Basis set: $6-31 \mathrm{G}(\mathrm{D})$

Number of shells: 66

Number of basis functions: 165

SCF model:

A restricted hybrid $\mathrm{HF}-\mathrm{DFT}$ SCF calculation will be performed using Pulay DIIS extrapolation

Optimization:

$\begin{array}{rc}\text { Step } & \text { Energy } \\ 1 & -388.8296006 \\ 2 & -388.8322548 \\ 3 & -388.8324462 \\ 4 & -388.8324684 \\ 5 & -388.8324733 \\ 6 & -388.8324741\end{array}$

$$
\begin{array}{r}
\text { Max Grad. } \\
0.024837
\end{array}
$$

Max Dist.

$0.003228 \quad 0.041711$

$0.000850 \quad 0.014210$

$0.000403 \quad 0.008002$

$0.000145 \quad 0.003393$

$0.000071 \quad 0.002135$

Dipole Moment (Debye) Tot 5.1344

* * GEOMETRY OPTIMIZATION IN DELOCALIZED INTERNAL COORDINATES **

\begin{tabular}{|c|c|c|c|c|}
\hline \multicolumn{2}{|c|}{ Optimization } & Cycle: $\quad 6$ & \\
\hline & ГOM & $\mathrm{X}$ & $\mathrm{Y}$ & $\mathrm{Z}$ \\
\hline 1 & $\mathrm{H}$ & -1.674720 & 2.185940 & -0.660021 \\
\hline 2 & $\mathrm{C}$ & -1.106932 & 1.582652 & 0.055643 \\
\hline 3 & $\mathrm{H}$ & -0.322488 & -3.076116 & -0.106646 \\
\hline 4 & $\mathrm{C}$ & 1.109609 & 0.172270 & 0.256039 \\
\hline 5 & $\mathrm{C}$ & 0.942843 & -1.305389 & -0.172393 \\
\hline 6 & $\mathrm{C}$ & 0.234375 & 1.159260 & -0.563619 \\
\hline 7 & $\mathrm{C}$ & -2.035970 & 0.412808 & 0.585827 \\
\hline 8 & $\mathrm{H}$ & 1.156736 & -1.415488 & -1.243075 \\
\hline 9 & $\mathrm{H}$ & 0.841211 & 0.254620 & 1.320404 \\
\hline 10 & $\mathrm{H}$ & 1.700006 & -1.909171 & 0.346747 \\
\hline 11 & $\mathrm{H}$ & 0.080704 & 0.762859 & -1.577599 \\
\hline 12 & $\mathrm{C}$ & -2.207601 & -0.545506 & -0.502275 \\
\hline 13 & $\mathrm{H}$ & -0.942941 & 2.208461 & 0.939751 \\
\hline 14 & $\mathrm{H}$ & -1.578746 & -0.039613 & 1.468046 \\
\hline 15 & C & 2.597772 & 0.545727 & 0.124517 \\
\hline 16 & $\mathrm{C}$ & -0.362424 & -2.017264 & 0.146588 \\
\hline 17 & $\mathrm{H}$ & 0.794749 & 2.090040 & -0.707986 \\
\hline
\end{tabular}
searching for a Minimum 


\begin{tabular}{|c|c|c|c|c|}
\hline 18 & $\mathrm{H}$ & -3.007769 & 0.838252 & 0.853094 \\
\hline 19 & $\mathrm{H}$ & -2.968433 & -0.386088 & -1.271265 \\
\hline 20 & 0 & -1.487586 & -1.552956 & -0.741278 \\
\hline 1 & $\mathrm{H}$ & -0.692726 & -1.896123 & 1.179884 \\
\hline 22 & $\mathrm{H}$ & 2.772747 & 1.566855 & 0.477041 \\
\hline 23 & $\mathrm{H}$ & 2.925837 & 0.489718 & -0.920415 \\
\hline & $\mathrm{H}$ & 3.231747 & -0.125747 & 0.712991 \\
\hline
\end{tabular}

Energy is $\quad-388.832474132$

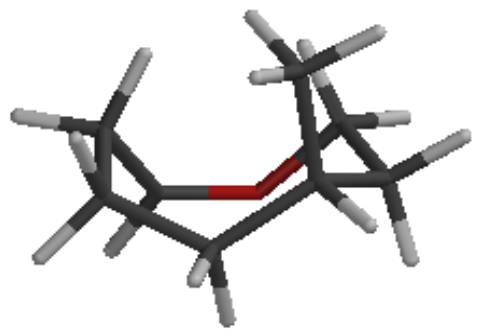

S41

SPARTAN 'O2 Quantum Mechanics Program:

Job type: Geometry optimization.

Method: RB3LYP

Basis set: $6-31 \mathrm{G}(\mathrm{D})$

Number of shells: 66

Number of basis functions: 165

$\mathrm{SCF}$ model:

A restricted hybrid HF-DFT SCF calculation will be performed using Pulay DIIS extrapolation

Optimization:

$\begin{array}{rc}\text { Step } & \text { Energy } \\ 1 & -388.8270166 \\ 2 & -388.8295329 \\ 3 & -388.8297859 \\ 4 & -388.8298784 \\ 5 & -388.8298916 \\ 6 & -388.8298941 \\ 7 & -388.8298975 \\ 8 & -388.8298923 \\ 9 & -388.8298969\end{array}$

$$
\begin{array}{r}
\text { Max Grad. } \\
0.019683 \\
0.005834 \\
0.004666 \\
0.001014 \\
0.000298 \\
0.000170 \\
0.000091 \\
0.000036 \\
0.000026
\end{array}
$$$$
\text { Max Dist. }
$$$$
0.058422
$$$$
0.070577
$$$$
0.033543
$$$$
0.009910
$$$$
0.003699
$$$$
0.003945
$$$$
0.001777
$$$$
0.001670
$$

0.000513

Dipole Moment (Debye) Tot 4.3000

* * GEOMETRY OPTIMIZATION IN DELOCALIZED INTERNAL COORDINATES ** searching for a Minimum

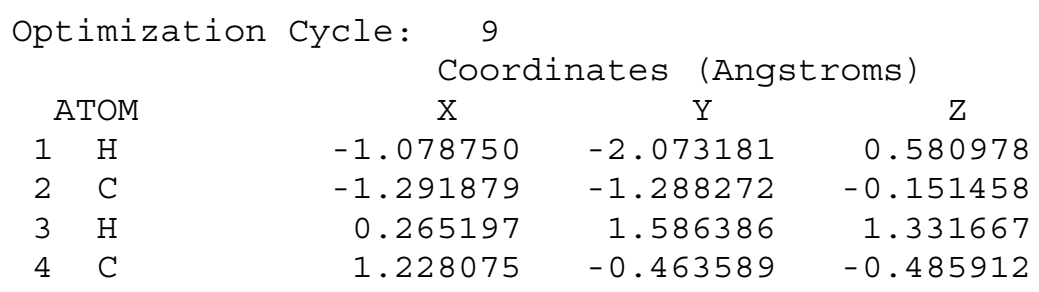




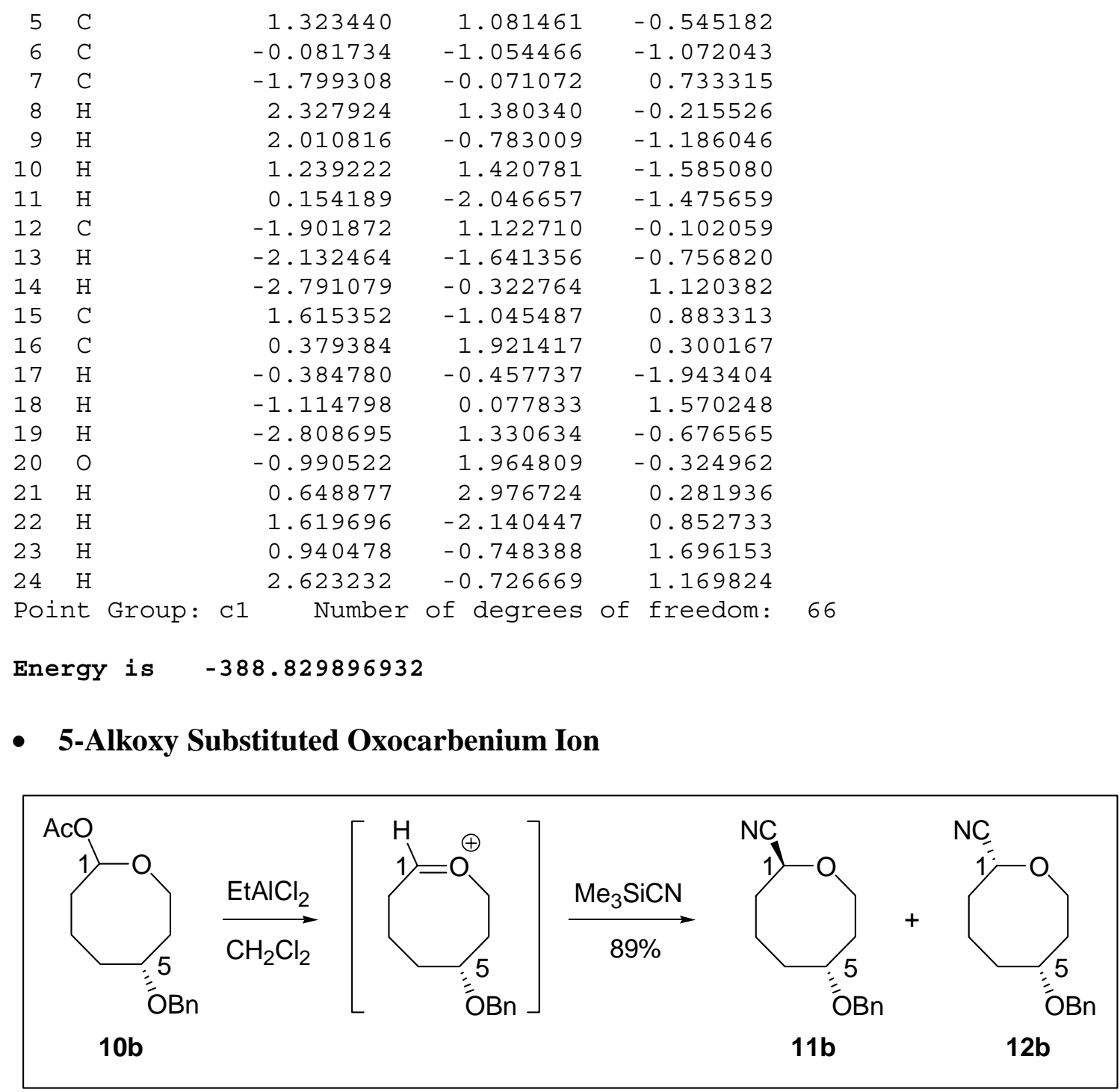




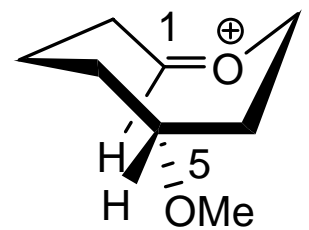

14

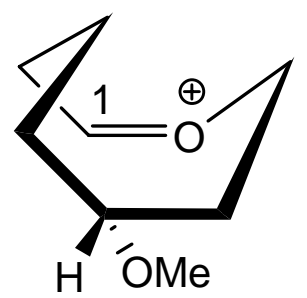

S42

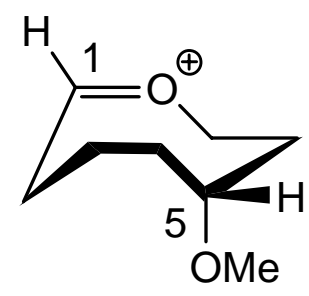

S43

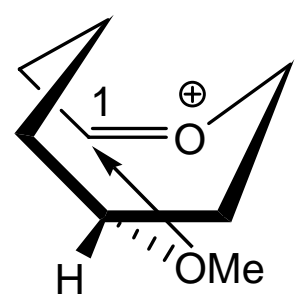

S44 (bridged)

\begin{tabular}{|ccc|}
\hline Cation & $\mathrm{E}_{\mathrm{rel}}(\mathrm{kcal} / \mathrm{mol})$ & Resulting Product \\
\hline $\mathbf{1 4}$ & 0 & 1,5 -trans \\
$\mathbf{S 4 2}$ & 0.08 & 1,5 -trans \\
$\mathbf{S 4 3}$ & 0.85 & 1,5 -cis \\
$\mathbf{S 4 4}$ & -7.7 & 1,5 -trans \\
\hline
\end{tabular}

The energy difference among these conformers suggests that nucleophilic attack should provide approximately a $90: 10$ trans : cis ratio of diastereomers at $273 \mathrm{~K}\left(\mathrm{~B} 3 \mathrm{LYP} / 6-31 \mathrm{G}^{*}\right)$. A discussion of the role of $\mathbf{S 4 4}$ in the conformational equilibrium parallels that described earlier for the C4-benzyloxy system.

Molecule Rel. E gas(kcal/mol) $\quad \operatorname{Dist}(\mathrm{C} 8, \mathrm{O} 1) \quad \operatorname{Dist}(\mathrm{O} 2, \mathrm{C} 8) \quad \operatorname{Dist}(\mathrm{O} 2, \mathrm{C} 1) \quad \operatorname{Dist}(\mathrm{O} 2, \mathrm{C} 2)$

$\begin{array}{llllll}\text { S44 } & 0.00000000 & 1.35177807 & 1.59571765 & 1.52477099 & 1.47032974 \\ 14 & 7.70896035 & 1.26689768 & 2.45120790 & 1.44002606 & 1.43273702 \\ \text { S43 } & 8.55923640 & 1.26185106 & 3.78410691 & 1.42155910 & 1.42909253\end{array}$

$\mathrm{C} 8, \mathrm{O} 1$ - oxocarbenium ion bond length

$\mathrm{O} 2, \mathrm{C} 8$ - distance between the remote methoxy oxygen atom and the carbocationic carbon Distance $(\mathrm{O} 2, \mathrm{C} 1)$ and $(\mathrm{O} 2, \mathrm{C} 2)$ - carbon oxygen bonds of the methoxy group

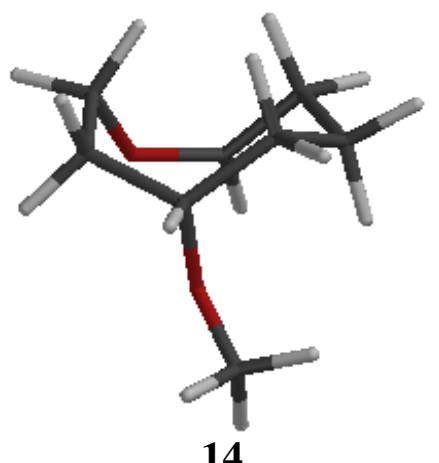


SPARTAN 'O2 Quantum Mechanics Program:

Job type: Geometry optimization.

Method: RB3LYP

Basis set: $6-31 \mathrm{G}(\mathrm{D})$

Number of shells: 70

Number of basis functions: 180

SCF model:

A restricted hybrid HF-DFT SCF calculation will be performed using Pulay DIIS extrapolation

Optimization:

$\begin{array}{rc}\text { Step } & \text { Energy } \\ 1 & -464.0292210 \\ 2 & -464.0372270 \\ 3 & -464.0390420 \\ 4 & -464.0400298 \\ 5 & -464.0405449 \\ 6 & -464.0407858 \\ 7 & -464.0409268 \\ 8 & -464.0410004 \\ 9 & -464.0410344 \\ 10 & -464.0410501 \\ 11 & -464.0410562 \\ 12 & -464.0410568\end{array}$

$\begin{array}{rr}\text { Max Grad. } & \text { Max Dist. } \\ 0.025782 & 0.141445 \\ 0.008844 & 0.143929 \\ 0.004490 & 0.114607 \\ 0.004853 & 0.111983 \\ 0.003861 & 0.102966 \\ 0.003612 & 0.063850 \\ 0.002462 & 0.045015 \\ 0.001271 & 0.041823 \\ 0.001298 & 0.029130 \\ 0.000611 & 0.010035 \\ 0.000222 & 0.006758 \\ 0.000125 & 0.002819\end{array}$

Dipole Moment (Debye) Tot 2.3004

** GEOMETRY OPTIMIZATION IN DELOCALIZED INTERNAL COORDINATES ** Searching for a Minimum

Optimization Cycle: 12

\begin{tabular}{rrrrr}
\multicolumn{2}{c}{ ATOM } & \multicolumn{3}{c}{ Coordinates (Angstroms) } \\
1 & $\mathrm{H}$ & 0.703605 & 2.429698 & -1.150783 \\
2 & $\mathrm{C}$ & 0.481625 & 1.885344 & -0.224370 \\
3 & $\mathrm{H}$ & 2.104963 & -1.344636 & -0.354121 \\
4 & $\mathrm{C}$ & -0.010450 & -1.607646 & -0.829599 \\
5 & $\mathrm{C}$ & 1.028332 & -0.699111 & 1.351682 \\
6 & $\mathrm{C}$ & 1.796130 & 1.292426 & 0.267557 \\
7 & $\mathrm{C}$ & -0.662481 & 0.881888 & -0.482369 \\
8 & $\mathrm{H}$ & 0.656426 & -1.090407 & 2.298414 \\
9 & $\mathrm{H}$ & 0.252278 & -2.331520 & -1.606775 \\
10 & $\mathrm{C}$ & 1.179626 & -1.597308 & 0.175783 \\
11 & $\mathrm{H}$ & 2.302543 & 0.668383 & -0.470046 \\
12 & $\mathrm{C}$ & -0.341746 & -0.260620 & -1.485993 \\
13 & $\mathrm{H}$ & 0.127664 & 2.619912 & 0.505963 \\
14 & $\mathrm{O}$ & -1.032659 & 0.344823 & 0.804690 \\
15 & $\mathrm{O}$ & 1.502828 & 0.472528 & 1.468070 \\
16 & $\mathrm{H}$ & -0.887648 & -2.005261 & -0.313625 \\
17 & $\mathrm{H}$ & 2.483898 & 2.051795 & 0.637166 \\
18 & $\mathrm{C}$ & -2.419259 & 0.011497 & 0.953345 \\
19 & $\mathrm{H}$ & 1.293270 & -2.610048 & 0.578507 \\
20 & $\mathrm{H}$ & 0.471241 & 0.049472 & -2.155325 \\
21 & $\mathrm{H}$ & -1.207760 & -0.424814 & -2.136081 \\
22 & $\mathrm{H}$ & -2.739240 & -0.759305 & 0.242283
\end{tabular}




$\begin{array}{rrrrr}23 & \mathrm{H} & -3.032351 & 0.910148 & 0.815956 \\ 24 & \mathrm{H} & -2.545357 & -0.357467 & 1.972944 \\ 25 & \mathrm{H} & -1.505479 & 1.470227 & -0.863276 \\ \text { Point Group: Cl } & \text { Number of degrees of freedom: }\end{array}$

Energy is $\quad-464.041056783$

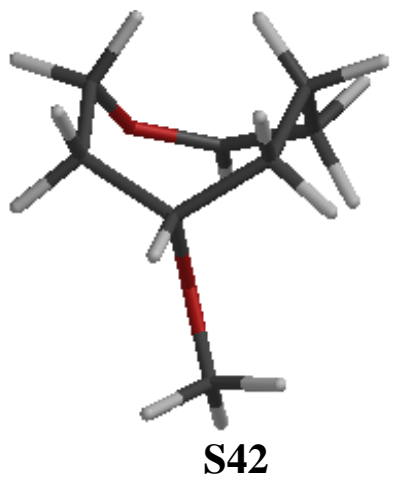

SPARTAN 'O2 Quantum Mechanics Program:

Job type: Frequency calculation

Method: RB3LYP

Basis set: 6-31G(D)

Number of shells: 70

Number of basis functions: 180

SCF model :

A restricted hybrid HF-DFT SCF calculation will be performed using Pulay DIIS extrapolation

SCF total energy: $\quad-464.0297732$ hartrees

SPARTAN PROPERTIES PACKAGE:

Molecule is non-linear

1 imaginary frequencies ignored in thermodynamics calculations.

Standard Thermodynamic quantities at $298.15 \mathrm{~K}$ and 1.00 atm

Translational Enthalpy:

Rotational Enthalpy:

Vibrational Enthalpy:

Ideal Gas Constant (RT) :

....Total Enthalpy:

Translational Entropy:

Rotational Entropy:

Vibrational Entropy:

....Total Entropy:

Free Energy (H-TS):

Translational Cv:

Rotational $\mathrm{CV}$ :

Vibrational $\mathrm{Cv}$ :
$0.889 \mathrm{kcal} / \mathrm{mol}$

$0.889 \mathrm{kcal} / \mathrm{mol}$

$3.867 \mathrm{kcal} / \mathrm{mol}$

$0.592 \mathrm{kcal} / \mathrm{mol}$

$147.979 \mathrm{kcal} / \mathrm{mol}$

$40.786 \mathrm{cal} / \mathrm{mol} . \mathrm{K}$

$29.355 \mathrm{cal} / \mathrm{mol} . \mathrm{K}$

$21.566 \mathrm{cal} / \mathrm{mol} . \mathrm{K}$

$91.707 \mathrm{cal} / \mathrm{mol} . \mathrm{K}$

$120.637 \mathrm{kcal} / \mathrm{mol}$

$2.981 \mathrm{Cal} / \mathrm{mol} . \mathrm{K}$

$2.981 \mathrm{cal} / \mathrm{mol} . \mathrm{K}$

$29.570 \mathrm{cal} / \mathrm{mol} . \mathrm{K}$ 
...Total CV: $\quad 35.531 \mathrm{cal} / \mathrm{mol} . \mathrm{K}$

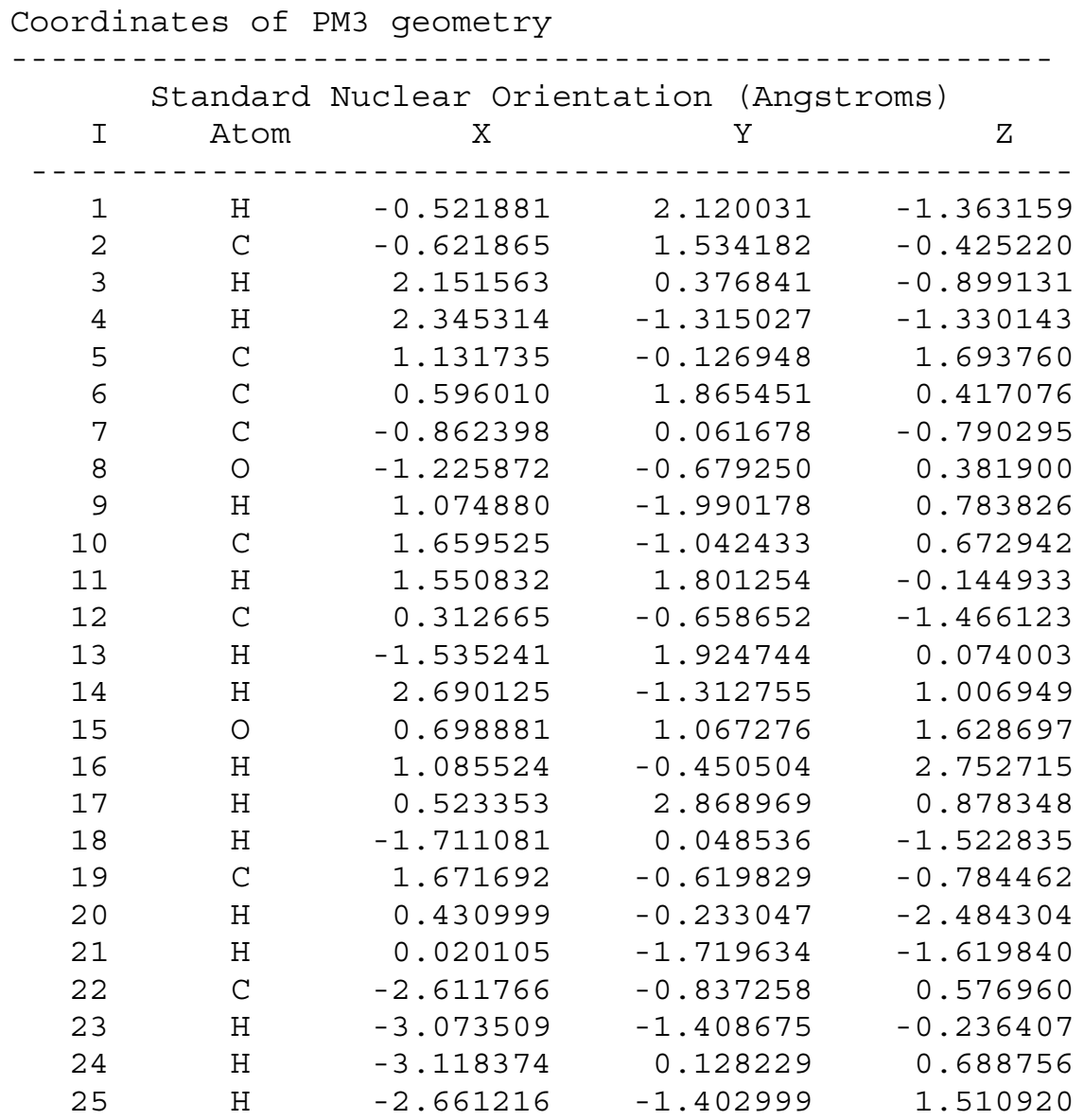

Dipole Moment (Debye) Tot 3.6492

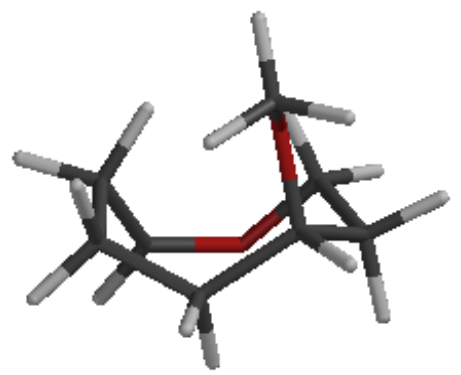

S43

SPARTAN 'O2 Quantum Mechanics Program:

Job type: Geometry optimization.

Method: RB3LYP

Basis set: $6-31 \mathrm{G}(\mathrm{D})$

Number of shells: 70

Number of basis functions: 180

SCF model:

A restricted hybrid HF-DFT SCF calculation will be performed using Pulay DIIS extrapolation 


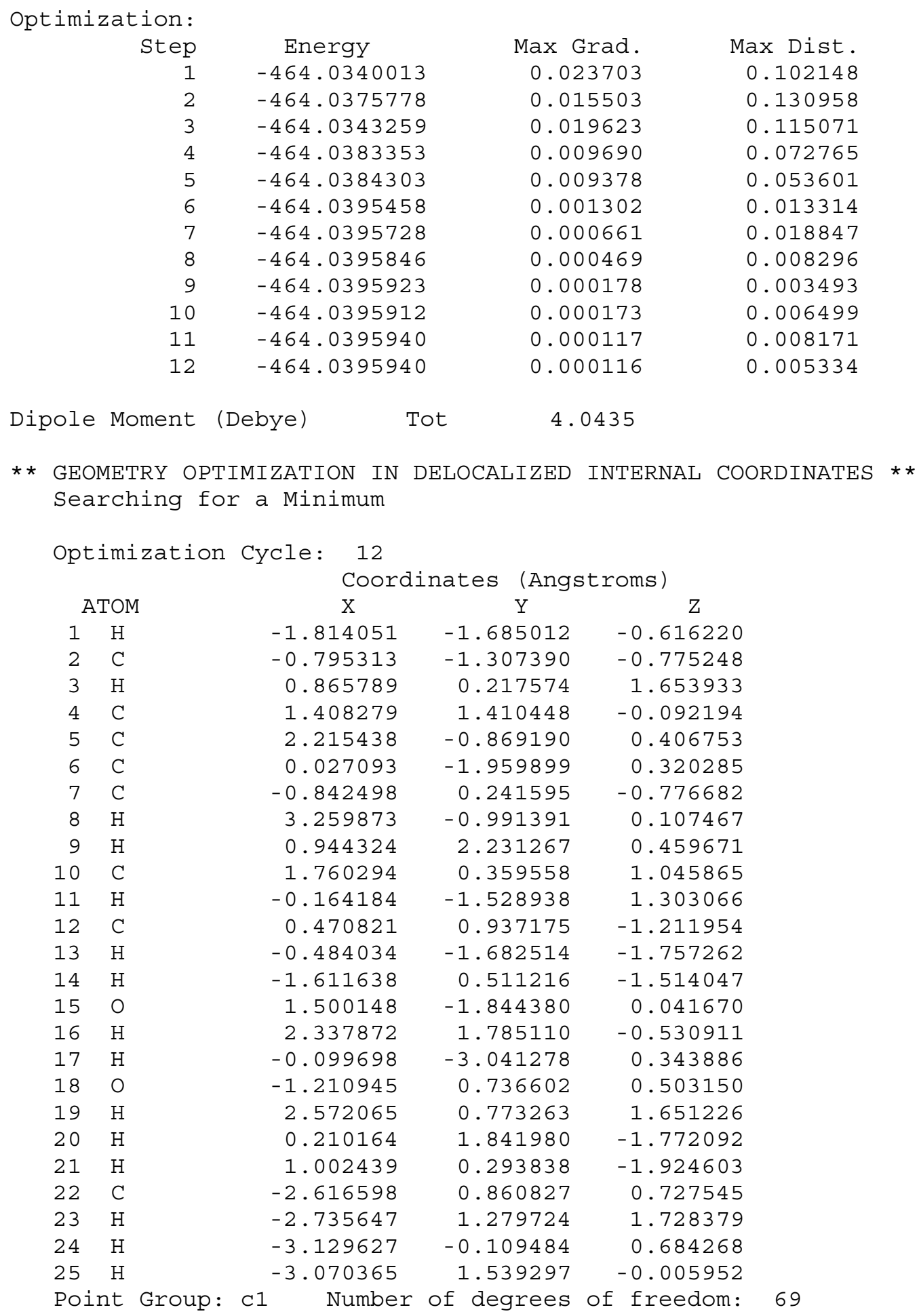

Energy is $\quad-464.039593965$ 

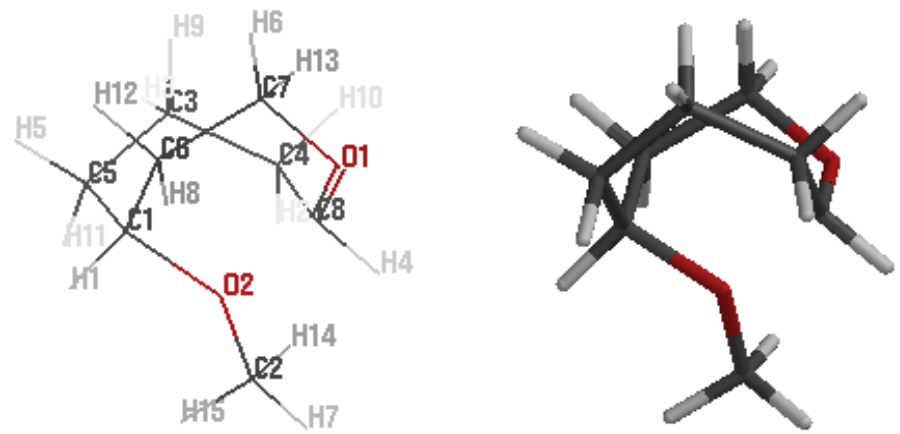

S44

SPARTAN 'O2 Quantum Mechanics Program:

Job type: Geometry optimization.

Method: RB3LYP

Basis set: $6-31 \mathrm{G}(\mathrm{D})$

Number of shells: 70

Number of basis functions: 180

SCF model:

A restricted hybrid HF-DFT SCF calculation will be performed using Pulay DIIS extrapolation

Optimization:

Step

\section{1}

2

3

4

5

6

7

8

9

10

11

12

13

14

15

16

17

18

19

20

21

22

23

24

25

$$
\begin{aligned}
& \text { Energy } \\
& -464.0297732 \\
& -464.0370163 \\
& -464.0386618 \\
& -464.0397180 \\
& -464.0405788 \\
& -464.0413764 \\
& -464.0422604 \\
& -464.0401931 \\
& -464.0437478 \\
& -464.0461119 \\
& -464.0474562 \\
& -464.0487970 \\
& -464.0503899 \\
& -464.0518201 \\
& -464.0516045 \\
& -464.0524876 \\
& -464.0528519 \\
& -464.0528514 \\
& -464.0526354 \\
& -464.0529394 \\
& -464.0530535 \\
& -464.0530925 \\
& -464.0530948 \\
& -464.0530977 \\
& -464.0530978
\end{aligned}
$$

$$
\begin{aligned}
& \text { Max Grad. } \\
& 0.018614 \\
& 0.006896 \\
& 0.004949 \\
& 0.003927 \\
& 0.003601 \\
& 0.004005 \\
& 0.004169 \\
& 0.016903 \\
& 0.011618 \\
& 0.004490 \\
& 0.008221 \\
& 0.016393 \\
& 0.014709 \\
& 0.011042 \\
& 0.035988 \\
& 0.007588 \\
& 0.004164 \\
& 0.007159 \\
& 0.010856 \\
& 0.006736 \\
& 0.003428 \\
& 0.000202 \\
& 0.000364 \\
& 0.000211 \\
& 0.000064
\end{aligned}
$$

Max Dist. 0.093289

0.185416

0.168575

0.143772

0.127472

0.123692

0.106442

0.154634

0.178544

0.191037

0.186146

0.164093

0.109802

0.117507

0.072033

0.108594

0.054626

0.102645

0.107139

0.048097

0.020642

0.005458

0.006009

0.003409

0.002249

Dipole Moment (Debye) Tot 1.9112

* * GEOMETRY OPTIMIZATION IN DELOCALIZED INTERNAL COORDINATES * * searching for a Minimum 


\begin{tabular}{|c|c|c|c|c|c|c|c|}
\hline \multicolumn{8}{|c|}{ Optimization Cycle: 25} \\
\hline \multicolumn{3}{|c|}{ ATOM } & \multirow{2}{*}{$\begin{array}{c}x \\
-0.312898\end{array}$} & $\mathrm{Y}$ & \multicolumn{3}{|c|}{$\mathrm{Z}$} \\
\hline 1 & $\mathrm{H}$ & & & 2.047331 & & -1.531563 & \\
\hline 2 & $\mathrm{C}$ & & -0.595038 & 1.522665 & & -0.611417 & \\
\hline 3 & $\mathrm{H}$ & & 2.229222 & 0.323305 & & -0.956846 & \\
\hline 4 & $\mathrm{H}$ & & 2.432302 & -1.372808 & & -1.306407 & \\
\hline 5 & $\mathrm{C}$ & & 0.320142 & -0.407282 & & 1.317132 & \\
\hline 6 & $\mathrm{C}$ & & 0.419859 & 1.834827 & & 0.496547 & \\
\hline 7 & $\mathrm{C}$ & & -0.731737 & 0.029800 & & -0.942986 & \\
\hline 8 & O & & -0.908510 & -0.746922 & & 0.357668 & \\
\hline 9 & $\mathrm{H}$ & & 1.395872 & -2.109162 & & 0.702318 & \\
\hline 10 & $\mathrm{C}$ & & 1.525004 & -1.024285 & & 0.614940 & \\
\hline 11 & $\mathrm{H}$ & & 1.455583 & 1.812617 & & 0.153478 & \\
\hline 12 & $\mathrm{C}$ & & 0.421563 & -0.670067 & & -1.655360 & \\
\hline 13 & $\mathrm{H}$ & & -1.576295 & 1.914858 & & -0.322561 & \\
\hline 14 & $\mathrm{H}$ & & 2.400886 & -0.764873 & & 1.221545 & \\
\hline 15 & $\mathrm{O}$ & & 0.250870 & 0.912165 & & 1.603300 & \\
\hline 16 & $\mathrm{H}$ & & 0.056131 & -0.954099 & & 2.222855 & \\
\hline 17 & $\mathrm{H}$ & & 0.227653 & 2.817062 & & 0.929061 & \\
\hline 18 & $\mathrm{H}$ & & -1.666144 & -0.155196 & & -1.477521 & \\
\hline 19 & $\mathrm{C}$ & & 1.739827 & -0.649628 & & -0.865211 & \\
\hline 20 & $\mathrm{H}$ & & 0.546581 & -0.193962 & & -2.634706 & \\
\hline 21 & $\mathrm{H}$ & & 0.111642 & -1.703816 & & -1.846118 & \\
\hline 22 & $\mathrm{C}$ & & -2.214417 & -0.621704 & & 1.021809 & \\
\hline 23 & $\mathrm{H}$ & & -2.974082 & -0.784491 & & 0.257750 & \\
\hline 24 & $\mathrm{H}$ & & -2.304835 & 0.360774 & & 1.486038 & \\
\hline 25 & $\mathrm{H}$ & & -2.249182 & -1.417109 & & 1.766254 & \\
\hline Po & at & Group : & Number & of degrees & of & freedom: & 69 \\
\hline
\end{tabular}

\section{3-Methyl Substituted Oxocarbenium Ion}

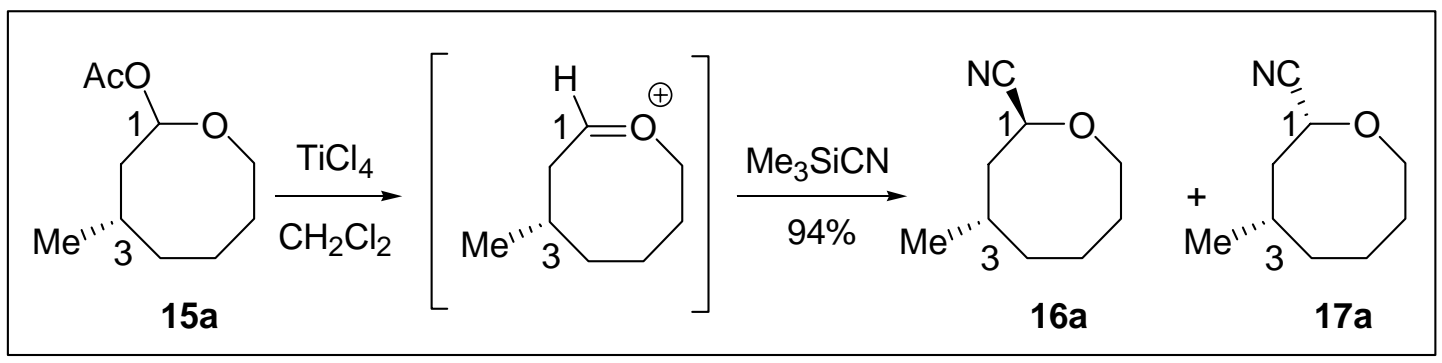




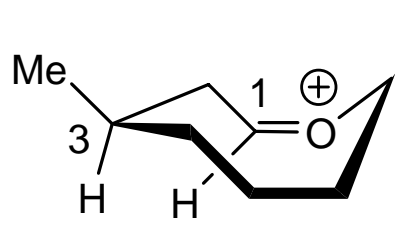

18

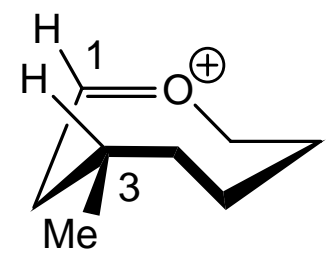

S45

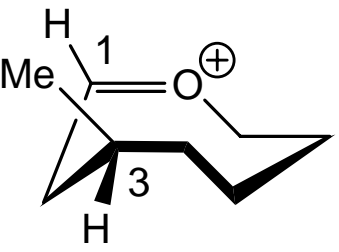

S46

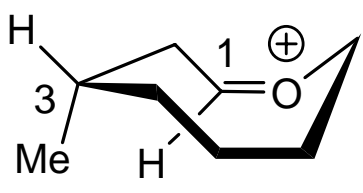

S47

\begin{tabular}{|ccc|}
\hline Cation & $\mathrm{E}_{\mathrm{rel}}(\mathrm{kcal} / \mathrm{mol})$ & Resulting Product \\
\hline $\mathbf{1 8}$ & 0 & 1,3 -cis \\
$\mathbf{S 4 5}$ & 0.3 & $1,3-$ cis \\
$\mathbf{S 4 6}$ & 0.5 & $1,3-$ trans \\
$\mathbf{S 4 7}$ & 1.6 & $1,3-$ trans \\
\hline
\end{tabular}

The energy differences among these conformers suggest that nucleophilic attack should provide approximately a 82 : 18 cis : trans ratio of diastereomers at $273 \mathrm{~K}$ (B3LYP/6-31G*).

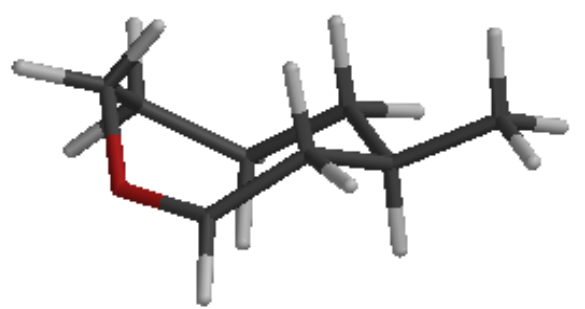

18

SPARTAN 'O2 Quantum Mechanics Program:

Job type: Geometry optimization.

Method: RB3LYP

Basis set: $6-31 \mathrm{G}(\mathrm{D})$

Number of shells: 66

Number of basis functions: 165

SCF model:

A restricted hybrid HF-DFT SCF calculation will be performed using Pulay DIIS extrapolation

Optimization:

step

Energy

$-388.8316738$

$-388.8343536$

$-388.8345894$

$-388.8346089$

Max Grad.

0.017680

Max Dist.

0.003979

0.058749

0.001272

0.036891

$-388.8346155$

0.000328

0.006241

$-388.8346154$

0.000103

0.007862

0.000036

0.002356

0.001306 
Dipole Moment (Debye) Tot 3.5732

* * GEOMETRY OPTIMIZATION IN DELOCALIZED INTERNAL COORDINATES * * searching for a Minimum

$\begin{array}{cc}\text { Optimization Cycle: } & 6 \\ & \text { Coordinates (Angstroms) }\end{array}$

\begin{tabular}{|c|c|c|c|c|}
\hline \multicolumn{2}{|c|}{ ATOM } & $\mathrm{X}$ & $\mathrm{Y}$ & Z \\
\hline 1 & $\mathrm{H}$ & 0.922052 & -0.780049 & -1.623342 \\
\hline 2 & $\mathrm{C}$ & 1.021539 & -1.251741 & -0.635053 \\
\hline 3 & O & 1.526769 & 1.638585 & -0.441926 \\
\hline 4 & C & -1.330592 & -0.128338 & -0.325527 \\
\hline 5 & C & -0.852813 & 1.333416 & 0.089855 \\
\hline 6 & $\mathrm{C}$ & -0.343149 & -1.237137 & 0.090168 \\
\hline 7 & C & 2.219256 & -0.640923 & 0.114680 \\
\hline 8 & $\mathrm{H}$ & -1.677831 & 2.021345 & -0.119786 \\
\hline 9 & C & -2.718997 & -0.342932 & 0.294430 \\
\hline 10 & $\mathrm{H}$ & -0.654224 & 1.337063 & 1.166391 \\
\hline 11 & $\mathrm{H}$ & -0.855051 & -2.182206 & -0.124111 \\
\hline 12 & $\mathrm{H}$ & 2.469790 & -1.253810 & 0.991094 \\
\hline 13 & $\mathrm{H}$ & 1.297779 & -2.288719 & -0.852636 \\
\hline 14 & $\mathrm{H}$ & 3.099286 & -0.655649 & -0.536984 \\
\hline 15 & $\mathrm{H}$ & -1.429533 & -0.142679 & -1.418490 \\
\hline 16 & $\mathrm{C}$ & 0.297998 & 1.808322 & -0.684745 \\
\hline 17 & $\mathrm{H}$ & -0.207156 & -1.223847 & 1.180982 \\
\hline 18 & $\mathrm{C}$ & 2.022226 & 0.767869 & 0.661517 \\
\hline 19 & $\mathrm{H}$ & 2.958823 & 1.245262 & 0.947587 \\
\hline 20 & $\mathrm{H}$ & 1.309447 & 0.823899 & 1.484751 \\
\hline 21 & $\mathrm{H}$ & 0.141691 & 2.377432 & -1.604857 \\
\hline 22 & $\mathrm{H}$ & -2.678665 & -0.301948 & 1.389047 \\
\hline 23 & $\mathrm{H}$ & -3.099507 & -1.328530 & 0.008417 \\
\hline 24 & $\mathrm{H}$ & -3.439139 & 0.405312 & -0.051461 \\
\hline
\end{tabular}

Point Group: c1 Number of degrees of freedom: 66

Energy is $\quad-388.834615422$

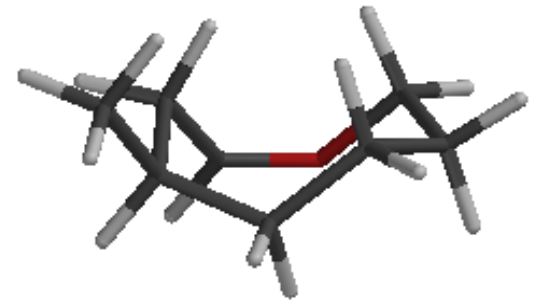

S45

SPARTAN 'O2 Quantum Mechanics Program:

Job type: Geometry optimization.

Method: RB3LYP

Basis set: $6-31 \mathrm{G}(\mathrm{D})$

Number of shells: 66

Number of basis functions: 165

SCF model :

A restricted hybrid HF-DFT SCF calculation will be performed using Pulay DIIS extrapolation 
Optimization:

$\begin{array}{rc}\text { Step } & \text { Energy } \\ 1 & -388.8312307 \\ 2 & -388.8336617 \\ 3 & -388.8341024 \\ 4 & -388.8341880 \\ 5 & -388.8341965 \\ 6 & -388.8341965\end{array}$

$$
\begin{array}{r}
\text { Max Grad. } \\
0.019908 \\
0.006092 \\
0.003606 \\
0.000854 \\
0.000205 \\
0.000075
\end{array}
$$$$
\text { Max Dist. }
$$$$
0.053880
$$$$
0.029652
$$$$
0.018898
$$$$
0.006138
$$

\begin{tabular}{|c|c|c|c|c|}
\hline \multicolumn{2}{|c|}{ АTOM } & $\mathrm{X}$ & $\mathrm{Y}$ & Z \\
\hline 1 & $\mathrm{H}$ & -0.750574 & -2.527512 & 0.052580 \\
\hline 2 & $\mathrm{C}$ & -0.614326 & -1.454033 & -0.114018 \\
\hline 3 & O & -1.586040 & 1.567976 & 0.518419 \\
\hline 4 & $\mathrm{C}$ & 1.407207 & 0.158984 & 0.430992 \\
\hline 5 & $\mathrm{C}$ & 0.697703 & 1.379535 & -0.316371 \\
\hline 6 & $\mathrm{C}$ & 0.427837 & -0.937273 & 0.906434 \\
\hline 7 & $\mathrm{C}$ & -2.020936 & -0.829233 & -0.017895 \\
\hline 8 & $\mathrm{H}$ & 1.450311 & 2.160034 & -0.461320 \\
\hline 9 & $\mathrm{C}$ & 2.493236 & -0.371283 & -0.517096 \\
\hline 10 & $\mathrm{H}$ & 0.332929 & 1.034945 & -1.286586 \\
\hline 11 & $\mathrm{H}$ & -0.088554 & -0.608631 & 1.818838 \\
\hline 12 & $\mathrm{H}$ & -2.705454 & -1.398483 & -0.661046 \\
\hline 13 & $\mathrm{H}$ & -0.235213 & -1.370473 & -1.141514 \\
\hline 14 & $\mathrm{H}$ & -2.414145 & -0.928245 & 1.001337 \\
\hline 15 & $\mathrm{H}$ & 1.900318 & 0.575108 & 1.317558 \\
\hline 16 & $\mathrm{C}$ & -0.367693 & 1.900279 & 0.531587 \\
\hline 17 & $\mathrm{H}$ & 1.056535 & -1.776136 & 1.225343 \\
\hline 18 & $\mathrm{C}$ & -2.188860 & 0.611781 & -0.470648 \\
\hline 19 & $\mathrm{H}$ & -3.231672 & 0.926461 & -0.461954 \\
\hline 20 & $\mathrm{H}$ & -1.744876 & 0.822966 & -1.445325 \\
\hline 21 & $\mathrm{H}$ & -0.141734 & 2.603488 & 1.337785 \\
\hline 22 & $\mathrm{H}$ & 2.064477 & -0.815519 & -1.422371 \\
\hline 23 & $\mathrm{H}$ & 3.073610 & -1.144823 & -0.003856 \\
\hline 24 & $\mathrm{H}$ & 3.185917 & 0.420089 & -0.820871 \\
\hline
\end{tabular}$$
0.003098
$$$$
0.000971
$$

Dipole Moment (Debye) Tot 3.7966

* * GEOMETRY OPTIMIZATION IN DELOCALIZED INTERNAL COORDINATES * * searching for a Minimum

$\begin{array}{cc}\text { Optimization Cycle: } & 6 \\ & \text { Coordinates (Angstroms) }\end{array}$

Energy is $\quad-388.834196495$

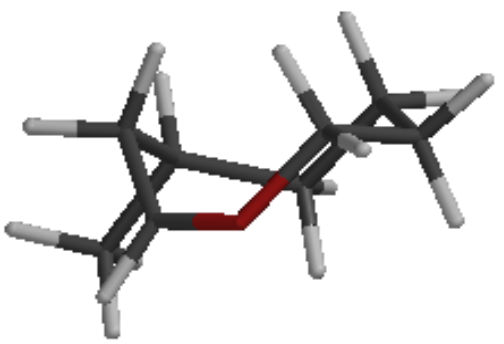

S46 
SPARTAN 'O2 Quantum Mechanics Program:

Job type: Geometry optimization.

Method: RB3LYP

Basis set: $6-31 \mathrm{G}(\mathrm{D})$

Number of shells: 66

Number of basis functions: 165

SCF model:

A restricted hybrid HF-DFT SCF calculation will be performed using Pulay DIIS extrapolation

Optimization:

$\begin{array}{rc}\text { Step } & \text { Energy } \\ 1 & -388.8308624 \\ 2 & -388.8335684 \\ 3 & -388.8338071 \\ 4 & -388.8338543 \\ 5 & -388.8338594 \\ 6 & -388.8338618 \\ 7 & -388.8338618\end{array}$

$\begin{array}{rr}\text { Max Grad. } & \text { Max Dist. } \\ 0.023990 & 0.050020 \\ 0.003487 & 0.031420 \\ 0.001912 & 0.019500 \\ 0.000533 & 0.010109 \\ 0.000285 & 0.005993 \\ 0.000097 & 0.001756 \\ 0.000024 & 0.000505\end{array}$

Dipole Moment (Debye) Tot 3.4275

* * GEOMETRY OPTIMIZATION IN DELOCALIZED INTERNAL COORDINATES ** Searching for a Minimum

\begin{tabular}{|c|c|c|c|c|}
\hline \multicolumn{2}{|c|}{ Optimization } & Cycle: $\quad 7$ & \multicolumn{2}{|c|}{ nates (Angstroms) } \\
\hline \multicolumn{2}{|c|}{ ATOM } & $\mathrm{X}$ & $\mathrm{Y}$ & Z \\
\hline 1 & $\mathrm{H}$ & -1.029767 & 1.229969 & -1.425586 \\
\hline 2 & $\mathrm{C}$ & -1.060809 & 1.388647 & -0.338277 \\
\hline 3 & 0 & -1.043500 & -1.637874 & 0.829883 \\
\hline 4 & $\mathrm{C}$ & 1.339958 & 0.296619 & -0.429543 \\
\hline 5 & $\mathrm{C}$ & 0.724812 & -1.144950 & -0.769097 \\
\hline 6 & $\mathrm{C}$ & 0.351386 & 1.245875 & 0.274233 \\
\hline 7 & $\mathrm{C}$ & -2.170942 & 0.525226 & 0.293158 \\
\hline 8 & $\mathrm{H}$ & -0.017931 & -1.031970 & -1.560735 \\
\hline 9 & $\mathrm{C}$ & 2.663930 & 0.185936 & 0.334426 \\
\hline 10 & $\mathrm{H}$ & 1.544161 & -1.779067 & -1.120328 \\
\hline 11 & $\mathrm{H}$ & 0.836247 & 2.228808 & 0.263782 \\
\hline 12 & $\mathrm{H}$ & -2.224340 & 0.702577 & 1.374310 \\
\hline 13 & $\mathrm{H}$ & -1.382136 & 2.427332 & -0.209080 \\
\hline 14 & $\mathrm{H}$ & -3.140649 & 0.847140 & -0.110051 \\
\hline 15 & $\mathrm{H}$ & 1.544388 & 0.691245 & -1.432503 \\
\hline 16 & $\mathrm{C}$ & 0.153394 & -1.728425 & 0.437689 \\
\hline 17 & $\mathrm{H}$ & 0.269207 & 0.980597 & 1.338422 \\
\hline 18 & $\mathrm{C}$ & -2.141490 & -0.974508 & 0.046708 \\
\hline 19 & $\mathrm{H}$ & -2.008784 & -1.250688 & -1.001208 \\
\hline 20 & $\mathrm{H}$ & -3.020733 & -1.473352 & 0.452405 \\
\hline 21 & $\mathrm{H}$ & 0.784617 & -2.250974 & 1.160466 \\
\hline 22 & $\mathrm{H}$ & 2.529043 & -0.200586 & 1.351765 \\
\hline 23 & $\mathrm{H}$ & 3.117760 & 1.178009 & 0.425448 \\
\hline 24 & $\mathrm{H}$ & 3.382181 & -0.455583 & -0.186288 \\
\hline Poi & it Group: & Number & of degrees & E freedom: \\
\hline
\end{tabular}

Energy is $\quad-388.833861819$ 


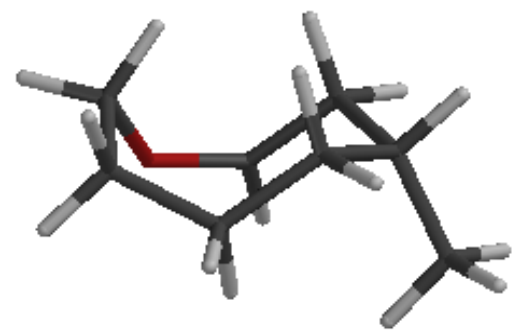

S47

SPARTAN 'O2 Quantum Mechanics Program:

Job type: Geometry optimization.

Method: RB3LYP

Basis set: $6-31 \mathrm{G}(\mathrm{D})$

Number of shells: 66

Number of basis functions: 165

SCF model :

A restricted hybrid HF-DFT SCF calculation will be performed using Pulay DIIS extrapolation

Optimization:

$\begin{array}{rc}\text { Step } & \text { Energy } \\ 1 & -388.8290115 \\ 2 & -388.8310291 \\ 3 & -388.8317692 \\ 4 & -388.8320230 \\ 5 & -388.8320519 \\ 6 & -388.8320557 \\ 7 & -388.8320575 \\ 8 & -388.8320561\end{array}$

$$
\begin{array}{r}
\text { Max Grad. } \\
0.015577 \\
0.012132 \\
0.004886 \\
0.000827 \\
0.000290 \\
0.000184 \\
0.000078 \\
0.000034
\end{array}
$$$$
\text { Max Dist. }
$$$$
0.089559
$$$$
0.130822
$$$$
0.061492
$$$$
0.024354
$$$$
0.009695
$$$$
0.005960
$$$$
0.001697
$$

0.000825

Dipole Moment (Debye) Tot 3.4625

* * GEOMETRY OPTIMIZATION IN DELOCALIZED INTERNAL COORDINATES * * Searching for a Minimum

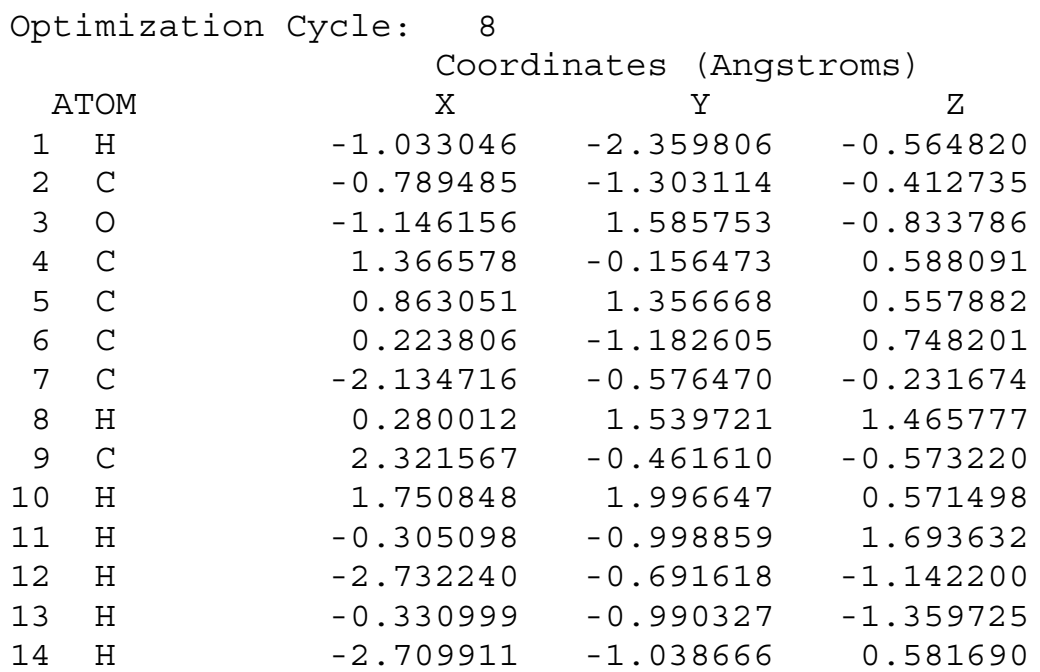




\begin{tabular}{|c|c|c|c|c|}
\hline 15 & $\mathrm{H}$ & 1.950771 & -0.182847 & 1.515250 \\
\hline 16 & $\mathrm{C}$ & 0.096903 & 1.712878 & -0.642224 \\
\hline 17 & $\mathrm{H}$ & 0.719123 & -2.151409 & 0.882773 \\
\hline 18 & $\mathrm{C}$ & -2.053334 & 0.901738 & 0.133069 \\
\hline 19 & $\mathrm{H}$ & -1.672827 & 1.084013 & 1.138440 \\
\hline 20 & $\mathrm{H}$ & -2.997738 & 1.426344 & -0.008115 \\
\hline 21 & $\mathrm{H}$ & 0.598525 & 2.143341 & -1.512192 \\
\hline 22 & $\mathrm{H}$ & 1.824804 & -0.469974 & -1.550035 \\
\hline 23 & $\mathrm{H}$ & 2.770608 & -1.449417 & -0.429499 \\
\hline 24 & $\mathrm{H}$ & 3.138955 & 0.266091 & -0.616079 \\
\hline
\end{tabular}

Energy is $\quad-388.832056111$

\section{- 3-Alkoxy Substituted Oxocarbenium Ion}

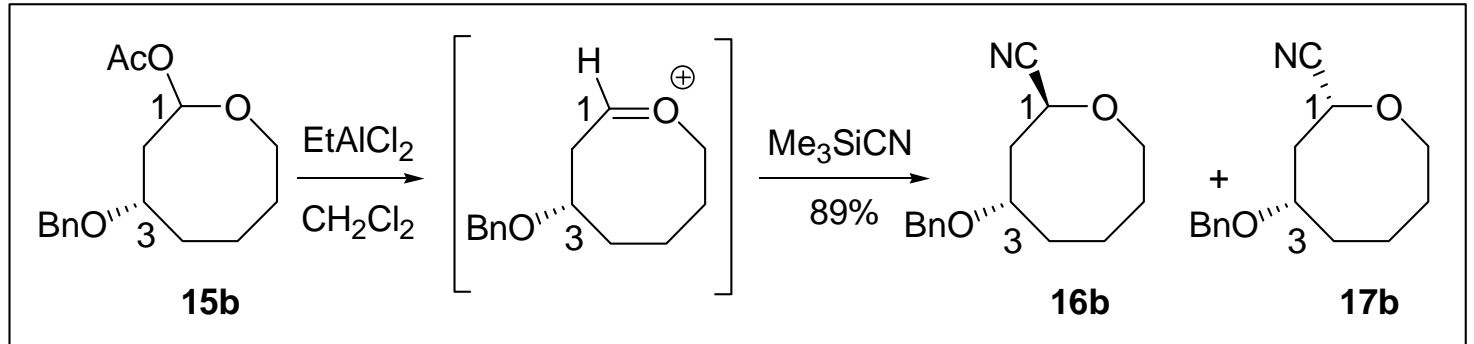

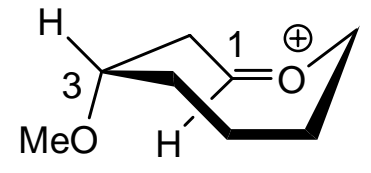

19

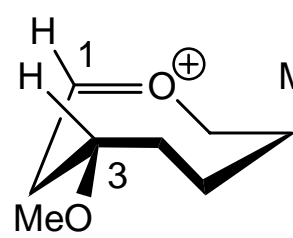

S48

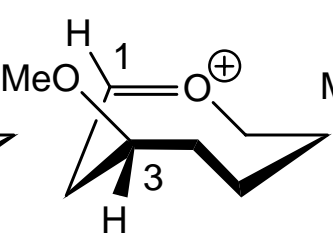

S49

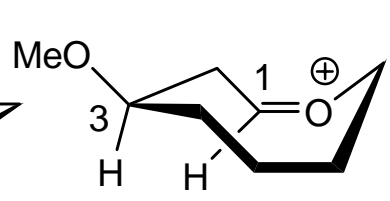

S50

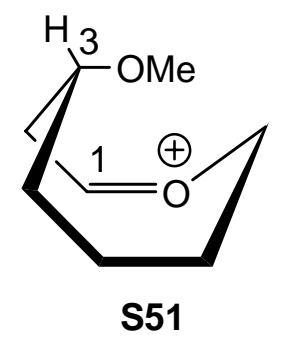

\begin{tabular}{|ccc|}
\hline Cation & $\mathrm{E}_{\mathrm{rel}}(\mathrm{kcal} / \mathrm{mol})$ & Resulting Product \\
\hline $\mathbf{1 9}$ & 0 & $1,3-$ trans \\
$\mathbf{S 4 8}$ & 0.9 & $1,3-\mathrm{cis}$ \\
$\mathbf{S 4 9}$ & 1.1 & $1,3-$ trans \\
S50 & 1.3 & $1,3-$ cis \\
S51 & 1.9 & $1,3-$ cis \\
\hline
\end{tabular}

The energy differences among these conformers suggest that nucleophilic attack should provide approximately a $80: 20$ trans : cis ratio of diastereomers at $273 \mathrm{~K}\left(\mathrm{~B} 3 \mathrm{LYP} / 6-31 \mathrm{G}^{*}\right)$. 


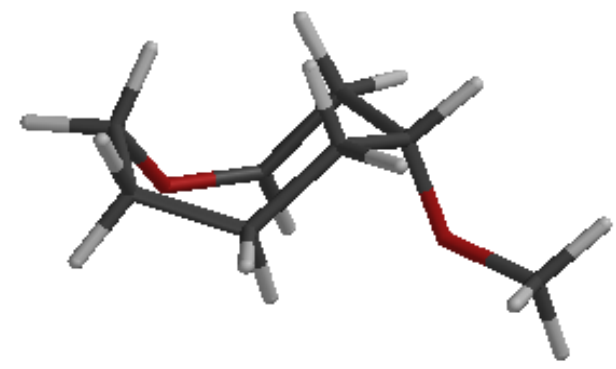

19

SPARTAN 102 Quantum Mechanics Program:

Job type: Geometry optimization.

Method: RB3LYP

Basis set: $6-31 G(D)$

Number of shells: 70

Number of basis functions: 180

SCF model:

A restricted hybrid HF-DFT SCF calculation will be performed using Pulay DIIS extrapolation

Optimization:

$\begin{array}{rc}\text { Step } & \text { Energy } \\ 1 & -464.0357162 \\ 2 & -464.0330137 \\ 3 & -464.0383522 \\ 4 & -464.0391478 \\ 5 & -464.0393699 \\ 6 & -464.0393781 \\ 7 & -464.0393855 \\ 8 & -464.0393852\end{array}$

$$
\begin{array}{r}
\text { Max Grad. } \\
0.016968
\end{array}
$$

Max Dist.

0.112962

$0.024519 \quad 0.094170$

$0.008611 \quad 0.064913$

$0.004221 \quad 0.045100$

$0.000611 \quad 0.014419$

$0.000356 \quad 0.005923$

$0.000208 \quad 0.004807$

$0.000096 \quad 0.001071$

Dipole Moment (Debye) Tot 3.4871

* * GEOMETRY OPTIMIZATION IN DELOCALIZED INTERNAL COORDINATES ** Searching for a Minimum

Optimization Cycle: 8

\begin{tabular}{rrrrr}
\multicolumn{3}{c}{ ATOM } & \multicolumn{3}{c}{ Coordinates } & \multicolumn{1}{c}{ (Angstroms) } \\
1 & $\mathrm{C}$ & 2.442153 & -0.443417 & -0.093998 \\
2 & $\mathrm{C}$ & 2.103407 & 1.035881 & -0.241817 \\
3 & $\mathrm{C}$ & -0.182577 & -1.710515 & 0.477417 \\
4 & $\mathrm{C}$ & -0.256537 & 0.872586 & 0.921925 \\
5 & $\mathrm{C}$ & -1.059607 & -0.412510 & 0.632569 \\
6 & $\mathrm{C}$ & 0.608177 & 1.403856 & -0.240404 \\
7 & $\mathrm{O}$ & 1.647047 & -1.226632 & -1.083310 \\
8 & $\mathrm{H}$ & 0.507279 & -1.793537 & 1.320857 \\
9 & $\mathrm{H}$ & -0.997592 & 1.636156 & 1.183906 \\
10 & $\mathrm{H}$ & -1.724582 & -0.605712 & 1.487885 \\
11 & $\mathrm{H}$ & 0.569469 & 2.498033 & -0.234127 \\
12 & $\mathrm{H}$ & 2.560876 & 1.418758 & -1.160088 \\
13 & $\mathrm{H}$ & 2.619801 & 1.528309 & 0.593283 \\
14 & $\mathrm{C}$ & 0.509265 & -1.708947 & -0.823007 \\
15 & $\mathrm{H}$ & 0.334194 & 0.726609 & 1.836341
\end{tabular}




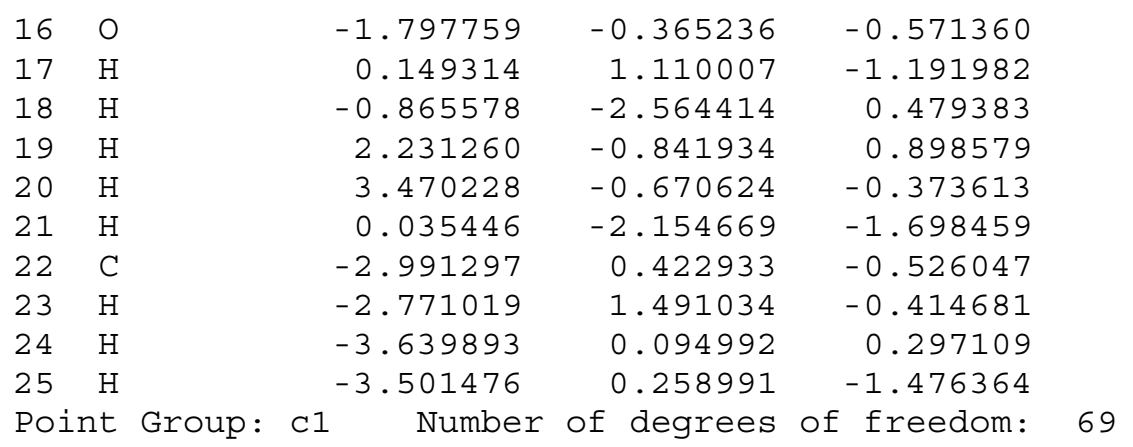

Energy is $\quad-464.039385189$

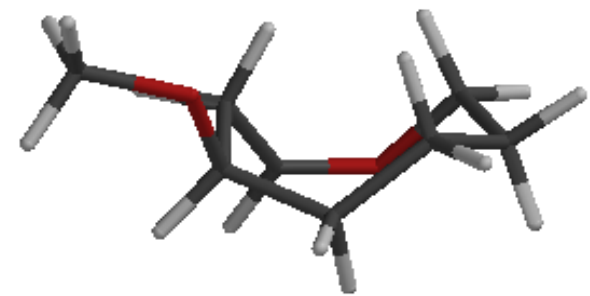

\section{S48}

SPARTAN 'O2 Quantum Mechanics Program:

Job type: Geometry optimization.

Method: RB3LYP

Basis set: $6-31 \mathrm{G}(\mathrm{D})$

Number of shells: 70

Number of basis functions: 180

SCF model :

A restricted hybrid HF-DFT SCF calculation will be performed using Pulay DIIS extrapolation

Optimization:

$\begin{array}{rc}\text { Step } & \text { Energy } \\ 1 & -464.0314770 \\ 2 & -464.0342705 \\ 3 & -464.0349767 \\ 4 & -464.0353397 \\ 5 & -464.0353993 \\ 6 & -464.0354272 \\ 7 & -464.0354439 \\ 8 & -464.0354533 \\ 9 & -464.0354603 \\ 10 & -464.0354678 \\ 11 & -464.0355226 \\ 12 & -464.0358416 \\ 13 & -464.0364071 \\ 14 & -464.0371340 \\ 15 & -464.0377518 \\ 16 & -464.0379717 \\ 17 & -464.0379973 \\ 18 & -464.0379994 \\ 19 & -464.0380030\end{array}$

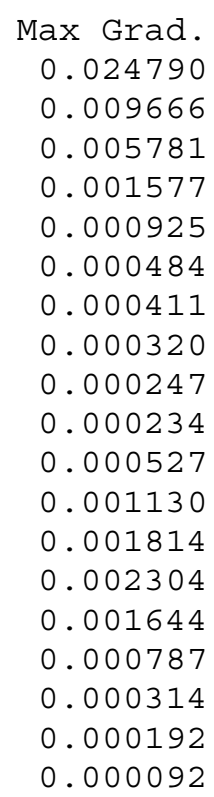

Max Grad.
0.024790
0.009666
0.005781
0.001577
0.000925
0.000484
0.000411
0.000320
0.000247
0.000234
0.000527
0.001130
0.001814
0.002304
0.001644
0.000787
0.000314
0.000192
0.000092

Max Dist.

0.098351

0.127399

0.041202

0.025868

0.027275

0.032098

0.021329

0.026226

0.039752

0.088172

0.109415

0.112511

0.115663

0.121069

0.122715

0.023072

0.005699

0.010117

0.002191 


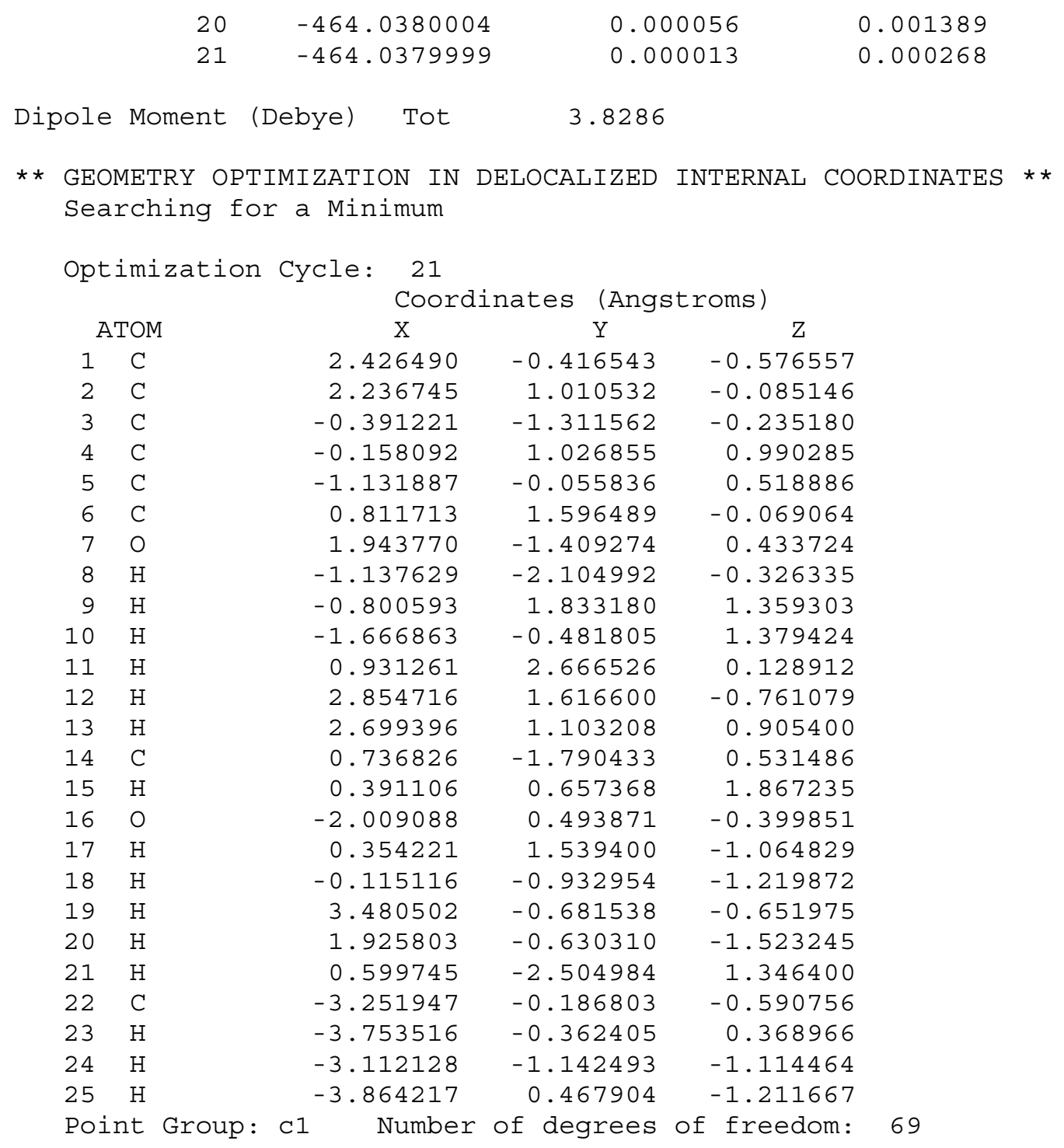

Energy is $\quad-464.037999854$

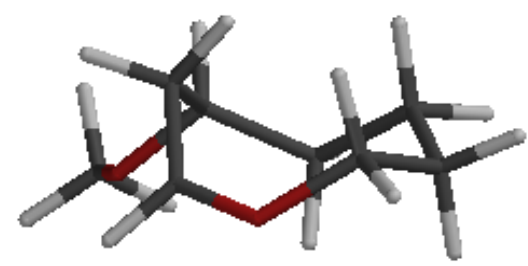

\section{S49}

SPARTAN 'O2 Quantum Mechanics Program:

Job type: Geometry optimization.

Method: RB3LYP

Basis set: $6-31 G(D)$

Number of shells: 70

Number of basis functions: 180 
SCF model:

A restricted hybrid HF-DFT SCF calculation will be performed using Pulay DIIS extrapolation

Optimization:

$\begin{array}{rc}\text { Step } & \text { Energy } \\ 1 & -464.0340117 \\ 2 & -464.0345124 \\ 3 & -464.0364161 \\ 4 & -464.0372268 \\ 5 & -464.0376310 \\ 6 & -464.0376776 \\ 7 & -464.0377109 \\ 8 & -464.0377186 \\ 9 & -464.0377194\end{array}$

$\begin{array}{rr}\text { Max Grad. } & \text { Max Dist. } \\ 0.022834 & 0.115989 \\ 0.018912 & 0.110419 \\ 0.012931 & 0.108586 \\ 0.004797 & 0.130185 \\ 0.002097 & 0.043671 \\ 0.001106 & 0.028077 \\ 0.000836 & 0.008575 \\ 0.000336 & 0.005825 \\ 0.000149 & 0.003886\end{array}$

Dipole Moment (Debye) Tot 3.3922

* * GEOMETRY OPTIMIZATION IN DELOCALIZED INTERNAL COORDINATES * * searching for a Minimum

Optimization Cycle: 9

\begin{tabular}{|c|c|c|c|c|c|}
\hline & & Coorc & lates (Ang & roms ) & \\
\hline & ГОМ & $\mathrm{X}$ & $\mathrm{Y}$ & $\mathrm{Z}$ & \\
\hline 1 & $\mathrm{C}$ & 2.520373 & -0.680135 & -0.191171 & \\
\hline 2 & $\mathrm{C}$ & 2.264377 & 0.813022 & -0.329562 & \\
\hline 3 & $\mathrm{C}$ & -0.207098 & -1.368435 & 0.767869 & \\
\hline 4 & $\mathrm{C}$ & -0.334019 & 1.077667 & -0.181213 & \\
\hline 5 & $\mathrm{C}$ & -1.100422 & -0.091834 & 0.465743 & \\
\hline 6 & $\mathrm{C}$ & 1.054088 & 1.425768 & 0.404747 & \\
\hline 7 & $\mathrm{O}$ & 1.512165 & -1.495925 & -0.948136 & \\
\hline 8 & $\mathrm{H}$ & 0.540168 & -1.119800 & 1.522725 & \\
\hline 9 & $\mathrm{H}$ & -0.251552 & 0.874823 & -1.257098 & \\
\hline 10 & $\mathrm{H}$ & -1.490266 & 0.209025 & 1.451003 & \\
\hline 11 & $\mathrm{H}$ & 1.098524 & 1.193493 & 1.477692 & \\
\hline 12 & $\mathrm{H}$ & 2.225782 & 1.066339 & -1.395986 & \\
\hline 13 & $\mathrm{H}$ & 3.181591 & 1.278383 & 0.056014 & \\
\hline 14 & C & 0.374869 & -1.808744 & -0.496158 & \\
\hline 15 & $\mathrm{H}$ & -0.983619 & 1. 955242 & -0.095626 & \\
\hline 16 & $\mathrm{O}$ & -2.129973 & -0.573103 & -0.362561 & \\
\hline 17 & $\mathrm{H}$ & 1.185969 & 2.510736 & 0.343198 & \\
\hline 18 & $\mathrm{H}$ & -0.887612 & -2.137354 & 1.142015 & \\
\hline 19 & $\mathrm{H}$ & 2.520705 & -1.036579 & 0.840502 & \\
\hline 20 & $\mathrm{H}$ & 3.445331 & -0.978530 & -0.682839 & \\
\hline 21 & $\mathrm{H}$ & -0.210759 & -2.404464 & -1.198223 & \\
\hline 22 & C & -3.342274 & 0.188493 & -0.332682 & \\
\hline 23 & $\mathrm{H}$ & -3.206581 & 1.185688 & -0.767517 & \\
\hline 24 & $\mathrm{H}$ & -3.713800 & 0.284551 & 0.696509 & \\
\hline 25 & $\mathrm{H}$ & -4.065966 & -0.368326 & -0.929243 & \\
\hline
\end{tabular}

Energy is $\quad-464.037719390$ 


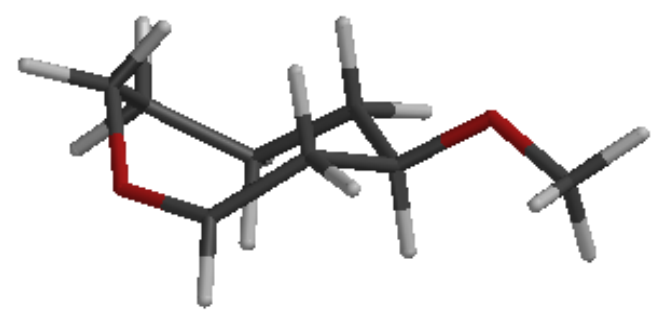

S50

SPARTAN 102 Quantum Mechanics Program:

Job type: Geometry optimization.

Method: RB3LYP

Basis set: $6-31 G(D)$

Number of shells: 70

Number of basis functions: 180

SCF model:

A restricted hybrid HF-DFT SCF calculation will be performed using Pulay DIIS extrapolation

Optimization:

$\begin{array}{rc}\text { Step } & \text { Energy } \\ 1 & -464.0313670 \\ 2 & -464.0344181 \\ 3 & -464.0353066 \\ 4 & -464.0354009 \\ 5 & -464.0354380 \\ 6 & -464.0354882 \\ 7 & -464.0264435 \\ 8 & -464.0354787 \\ 9 & -464.0357622 \\ 10 & -464.0359834 \\ 11 & -464.0363226 \\ 12 & -464.0368990 \\ 13 & -464.0372182 \\ 14 & -464.0369331 \\ 15 & -464.0373647 \\ 16 & -464.0373807 \\ 17 & -464.0373801\end{array}$

Max Grad.
0.016814
0.008842
0.003256
0.000890
0.000580
0.000671
0.026873
0.001524
0.001131
0.003740
0.005164
0.003545
0.002497
0.004726
0.000493
0.000341
0.000167

Max Dist.

0.098145

0.091989

0.039739

0.042149

0.075218

0.100780

0.097514

0.125372

0.141205

0.130613

0.117822

0.097442

0.116776

0.071139

0.031870

$-464.0373807$

0.008348

0.013546

Dipole Moment (Debye) Tot 3.5416

* * GEOMETRY OPTIMIZATION IN DELOCALIZED INTERNAL COORDINATES ** Searching for a Minimum

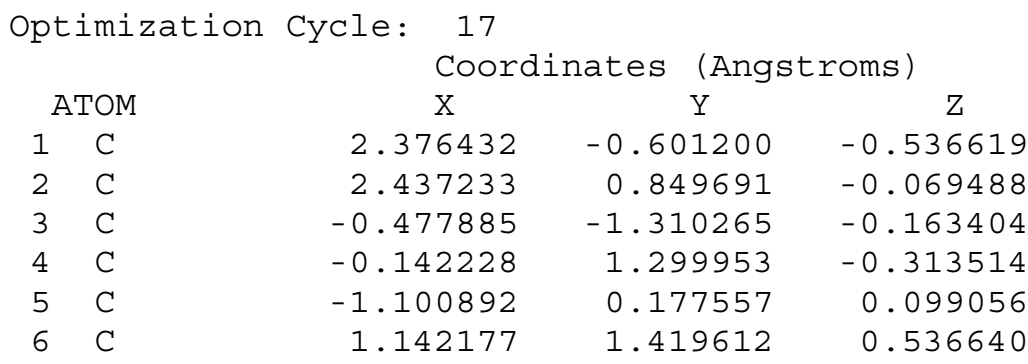




\begin{tabular}{|c|c|c|c|c|}
\hline 7 & 0 & 1.852774 & -1.434155 & 0.574041 \\
\hline 8 & $\mathrm{H}$ & -1.296329 & -2.013243 & 0.014748 \\
\hline 9 & $\mathrm{H}$ & 0.082050 & 1.205804 & -1.384025 \\
\hline 10 & $\mathrm{H}$ & -1.337929 & 0.249726 & 1.170612 \\
\hline 11 & $\mathrm{H}$ & 0.977204 & 0.984566 & 1.533419 \\
\hline 12 & $\mathrm{H}$ & 2.723404 & 1.428773 & -0.957244 \\
\hline 13 & $\mathrm{H}$ & 3.252194 & 0.959857 & 0.653412 \\
\hline 14 & $\mathrm{C}$ & 0.612815 & -1.667260 & 0.726395 \\
\hline 15 & $\mathrm{H}$ & -0.729808 & 2.218465 & -0.215335 \\
\hline 16 & 0 & -2.240467 & 0.273899 & -0.680035 \\
\hline 17 & $\mathrm{H}$ & 1.334919 & 2.479399 & 0.731388 \\
\hline 18 & $\mathrm{H}$ & -0.198496 & -1.326112 & -1.218942 \\
\hline 19 & $\mathrm{H}$ & 3.362506 & -1.024104 & -0.724930 \\
\hline 20 & $\mathrm{H}$ & 1.736650 & -0.748408 & -1.406247 \\
\hline 21 & $\mathrm{H}$ & 0.411902 & -2.180123 & 1.669491 \\
\hline 22 & C & -3.453552 & -0.220075 & -0.107404 \\
\hline 23 & $\mathrm{H}$ & -3.647287 & 0.250210 & 0.864677 \\
\hline 24 & $\mathrm{H}$ & -3.429953 & -1.312824 & 0.011219 \\
\hline 25 & $\mathrm{H}$ & -4.247432 & 0.040256 & -0.807910 \\
\hline
\end{tabular}

Energy is $\quad-464.037380082$

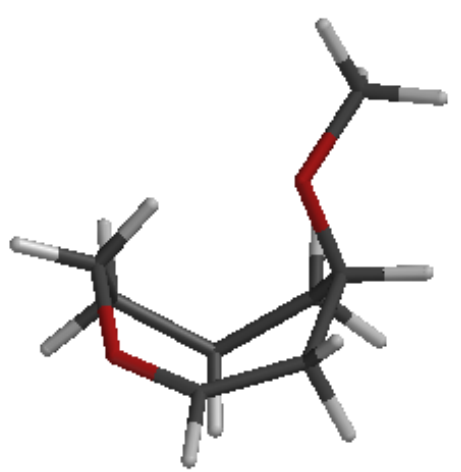

S51

SPARTAN 'O2 Quantum Mechanics Program:

Job type: Geometry optimization.

Method: RB3LYP

Basis set: $6-31 \mathrm{G}(\mathrm{D})$

Number of shells: 70

Number of basis functions: 180

SCF model:

A restricted hybrid HF-DFT SCF calculation will be performed using Pulay DIIS extrapolation

Optimization:

$\begin{array}{rc}\text { Step } & \text { Energy } \\ 1 & -464.0323579 \\ 2 & -464.0354707 \\ 3 & -464.0357524 \\ 4 & -464.0360743 \\ 5 & -464.0361211 \\ 6 & -464.0361625 \\ 7 & -464.0362226\end{array}$

Max Grad.
0.018589
0.006573
0.005463
0.001412
0.001335
0.000877
0.001214

Max Dist.

0.071429

0.104832

0.035596

0.019483

0.018442

0.050570

0.036545 


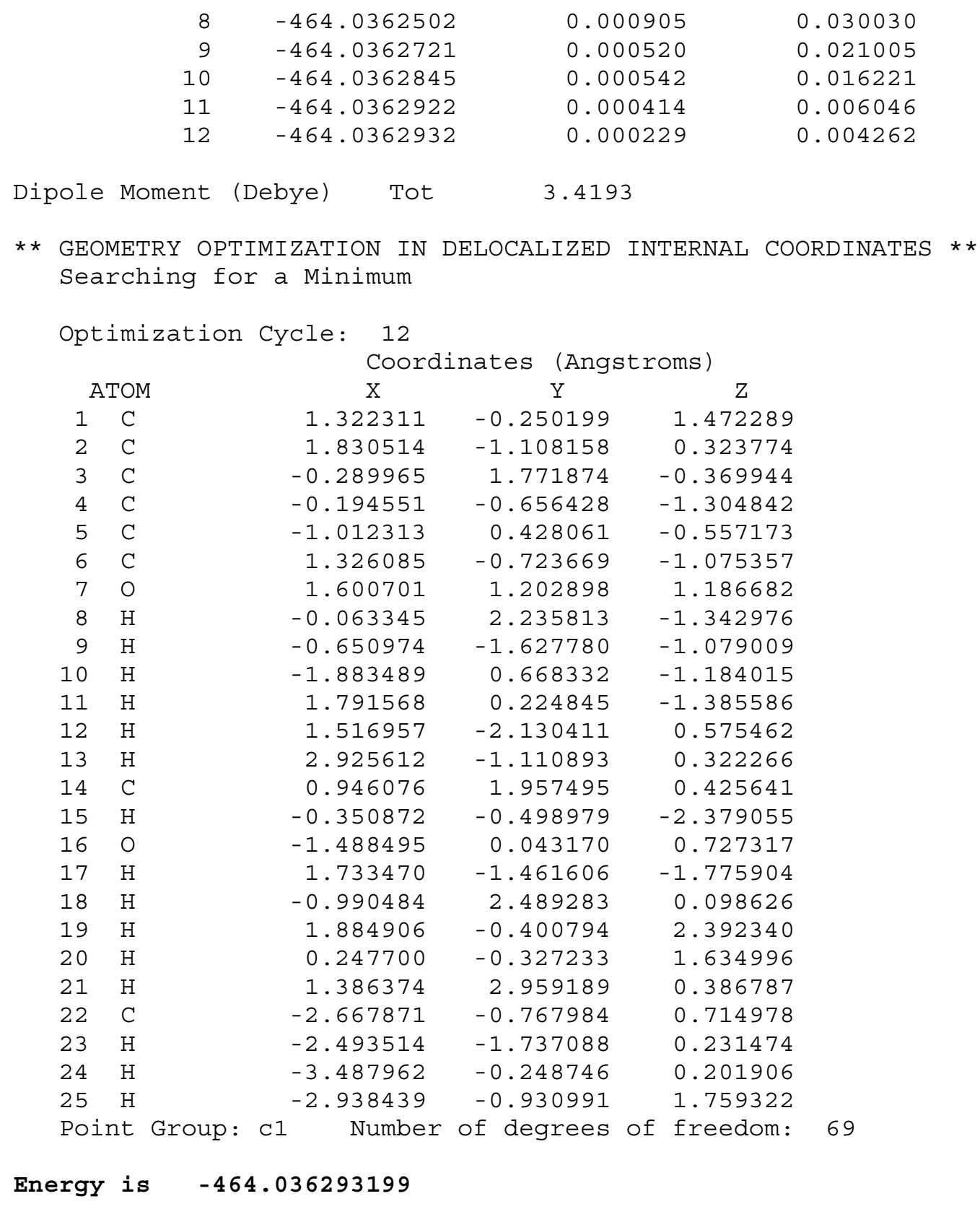

\section{Bibliography}

Pangborn, A. B.; Giardello, M. H.; Grubbs, R. H.; Rosen, R. K.; Timmers, F. J. Organometallics, 1996, 15, 1518-1520.

2 Prepared using the method of Lee, E.; Yoo, C. H.; Lee, T. H.; Kim, S. Y.; Ha, T. J.; Sung, Y.; Park, S, -H.; Lee, S. J. Am. Chem. Soc. 1998, 120, 7469-7478.

3 Prepared from 4-methyl-4-penten-1-ol in 93\% yield using the method described in ref. 2. 4-Methyl4-penten-1-ol was prepared in 99\% yield according to the method of Pirrung, M. C. J. Am. Chem. Soc. 1981, 103, 82-87.

4 Prepared according to the procedure reported by Kopecky, D. J.; Rychnovsky, S. D. Org. Synth. 2003, 80, 177-183.

5 Prepared according to the method of Markó, I. E.; Bayston, D. J. Tetrahedron, 1994, 50, 7141-7156. 
Prepared according to the method reported by Freeman, F.; Kim, D. S. H. L. J. Org. Chem. 1992, 57, 1722 1727. The spectral data correlates with the previously reported data for this aldehyde and its precursor, 4[(tert-butyldiphenylsilyl)oxy]butanol.

Brown, H. C.; Vara Prassad, J. V. N.; Zee, S. -H. J. Org. Chem. 1985, 50, 1582-1589.

Prepared according to the procedure reported by Soderquist, J. A.; Negron, A. Org Synth. 1992, 33(46), 6919-6922.

Bowden, K.; Heilbron, I. M.; Jones, E. R. H.; Weedon, B. C. L. J. Am. Chem. Soc. 1946, 68, 39-45.

Prepared according to the procedure described in footnote 10 of Djerassi, C.; Engle, R. R.; Bowers, A. J. Org. Chem. 1956, 21, 1547-1549.

Procedure adapted from Sparks, M. A.; Panek, J. S. J. Org. Chem. 1991, 56, 3431-3438.

Adapted from a procedure reported by Inanaga, J.; Hirata, K.; Saeki, H.; Katsuki, T.; Yamaguchi, M. Bull. Chem. Soc. Jpn. 1979, 52(7), 1989-1993.

Prepared in two steps from crotyl alcohol using the method of Gadwood, R. C.; Lett, R. M.; Wissinger, J. E. J. Am. Chem. Soc. 1986, 108, 6343-6350. The spectral data correlates with the previously reported data for $\mathbf{S 1 0}$ and for its precursor, ethyl-3-methylpent-4-enoate.

Reitz, A. B.; Nortey, S. O.; Maryanoff, B. E.; Liotta, D.; Monahan, III, R. J. Org. Chem. 1987, 52, 41914202.

Marcus, J.; van Meurs, P. J.; van den Nieuwendijk, A. M. C. H.; Porchet, M.; Brussee, J.; van der Gen, A. Tetrahedron 2000, 56, 2491-2495.

Prepared according to a procedure developed by Crimmins, M. T.; Cleary, P. A. Heterocycles 2003, 61, 87-92.

One gram samples of Grubbs' first generation catalyst and the Hoveyda-Grubbs second generation catalyst were kindly provided by Materia.

Purchased from Strem Chemicals, Newburyport, MA.

Prepared according to the procedure reported by Wang, J.; Li, C. J. Org. Chem. 2002, 67, 1271-1276.

Adapted from a procedure reported by Curran, D. P.; Chang, C. -T. J. Org. Chem. 1989, 54, 3140-3157.

Murphy, J. A.; Rasheed, F.; Roome, S. J.; Scott, K. A.; Lewis, N. J. Chem. Soc., Perkin Trans. 1 1998, 2331-2339.

Prepared according to the procedure reported by Kobayashi, S.; Furuta, T. Tetrahedron 1998, 54, 1027510294.

Prepared from ethyl thioacetate according to the method of Simchen, G.; West, W. Synth. Commun. 1977, 247-248. The boiling point and spectral data correlate with the reported data. Ethyl thioacetate prepared from ethanethiol using the method of Schleppnik, A. A.; Zienty, F. B. J. Org. Chem. 1964, 29, 1910-1915. Prepared according to the procedure reported by Shiina, I.; Fujisawa, H.; Ishii, T.; Fukuda, Y.

Heterocycles 2000, 52, 1105-1123.

Prepared according to the procedure reported by Widmer, U. Synth. Commun. 1987, 568-570.

Adapted from a procedure reported by Hanessian, S.; Lavallee, P. Can. J. Chem. 1975, 53, 2975.

Prepared according to the procedure reported by Eh, M.; Schomburg, D.; Schicht, K.; Kalesse, M.

Tetrahedron 1995, 51, 8983-8992.

Prepared according to the procedure reported by Kocieński, P.; Jarowicki, K.; Marczak, S. Synthesis 1991, 1191-1200.

Citation for SPARTAN '02

Wavefunction Developers:

B.J. Deppmeier, A.J. Driessen, T.S. Hehre, W.J. Hehre, J.A. Johnson, P.E. Klunzinger, J.M. Leonard, I.N. Pham, W.J. Pietro, Jianguo Yu

Q-Chem Developers:

J. Kong, C.A. White, A.I. Krylov, C.D. Sherrill, R.D. Adamson, T.R. Furlani, M.S. Lee, A.M. Lee, S.R. Gwaltney, T.R. Adams, C. Ochsenfeld, A.T.B. Gilbert, G.S. Kedziora, V.A. Rassolov, D. R. Maurice, N. Nair, Y. Shao, N.A. Besley, P.E. Maslen, J.P. Dombroski, H. Dachsel, W.M. Zhang, P.P. Korambath, J. Baker, E.F. C. Byrd, T. Van Voorhis, M. Oumi, S. Hirata, C.P. Hsu, N. Ishikawa, J. Florian, A. Warshel, B.G. Johnson, P.M.W. Gill, M. Head-Gordon, J.A. Pople

Wavefunction Inc. Sales: sales@ wavefun.com Irvine CA Support: support@wavefun.com 
VIII. Analytical Data

GC Analysis of Isomer Ratios and ${ }^{1} \mathrm{H}$ NMR Spectra of Relevant Compounds
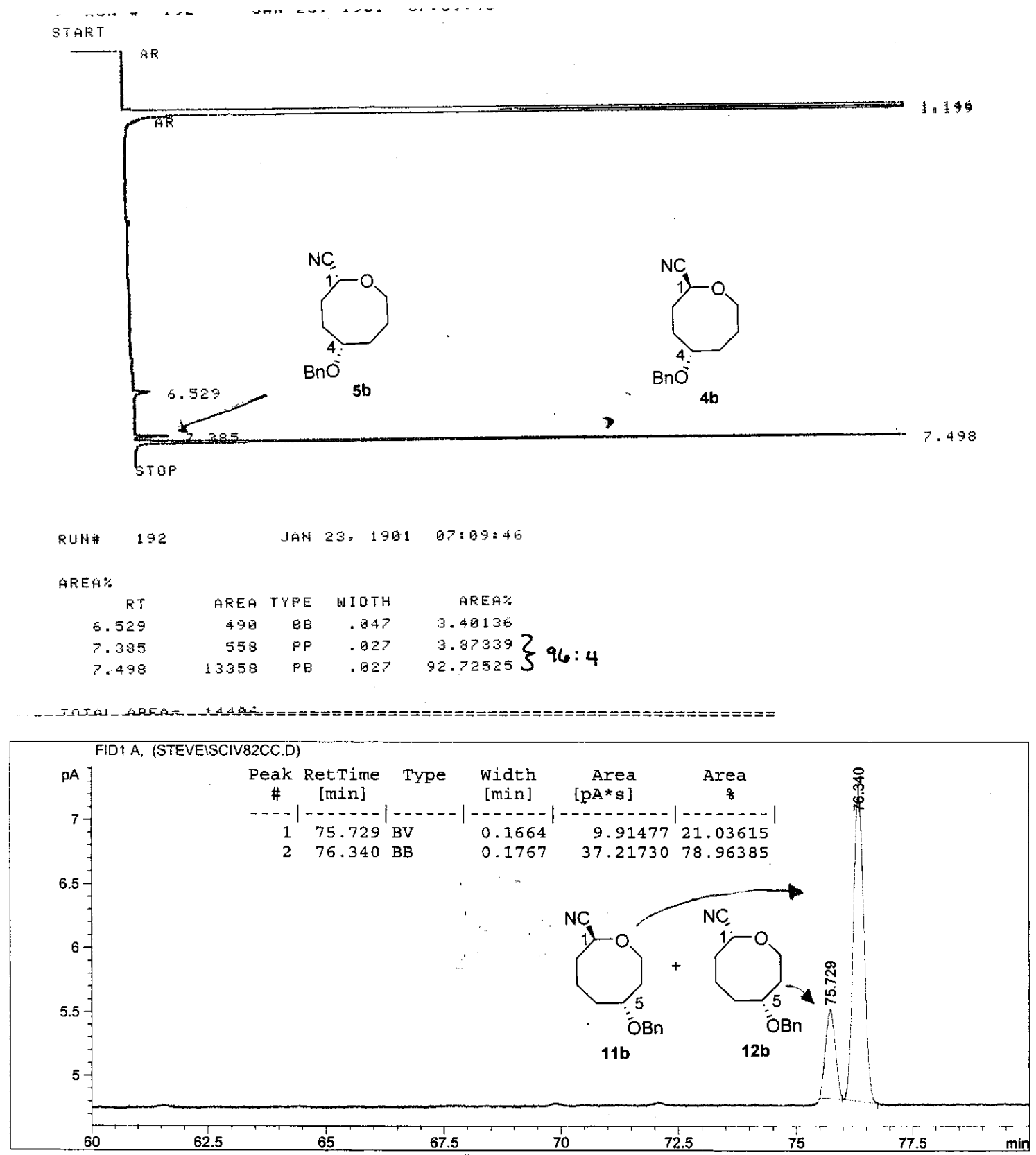

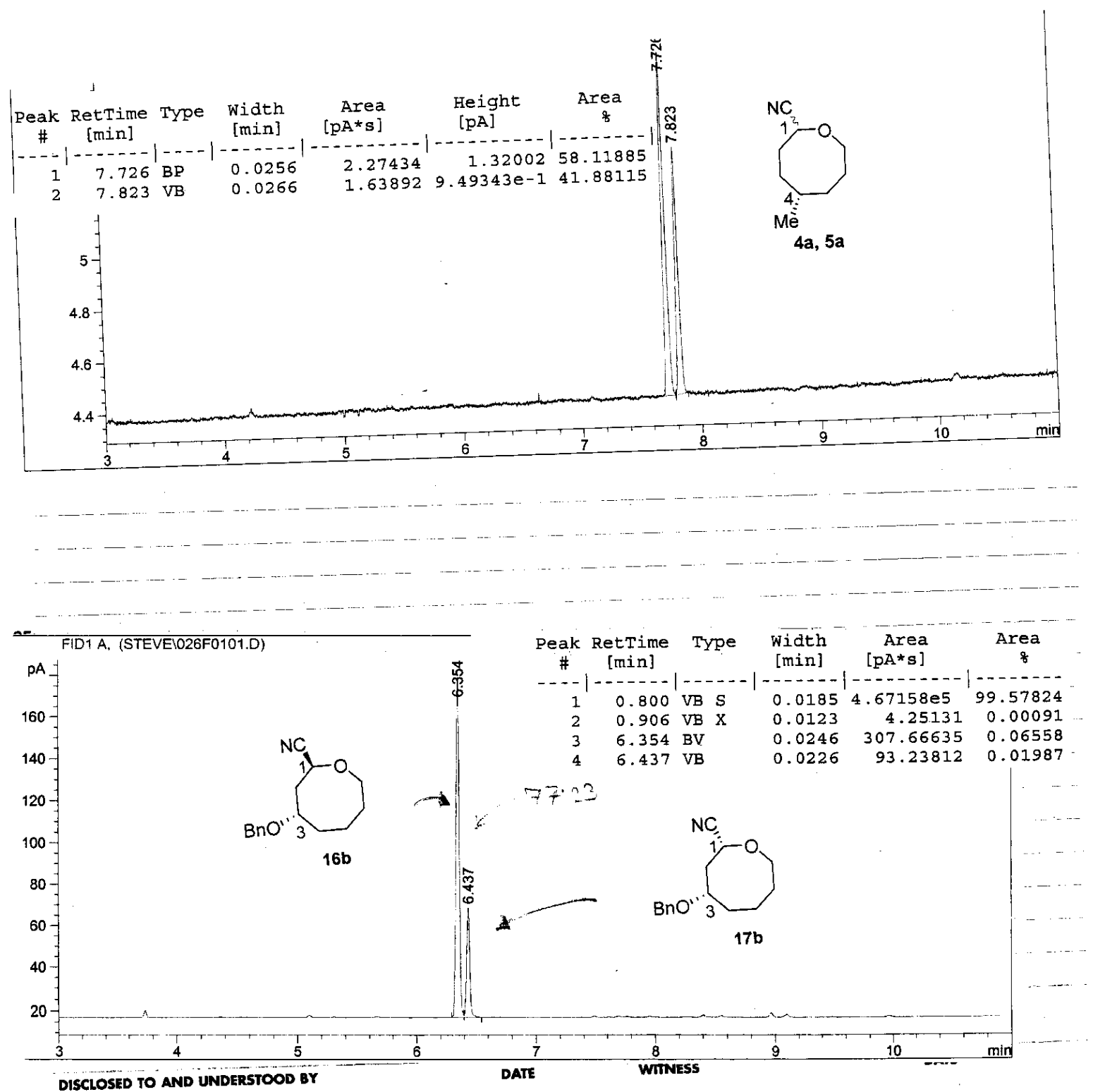
ata File $C: \backslash H P C H E M \backslash I \backslash D A T A \backslash S T E V E \backslash 019 F 0601 . D$

crude product, 5-Me, TMSCN, TiCl4, -78 to rt, ih

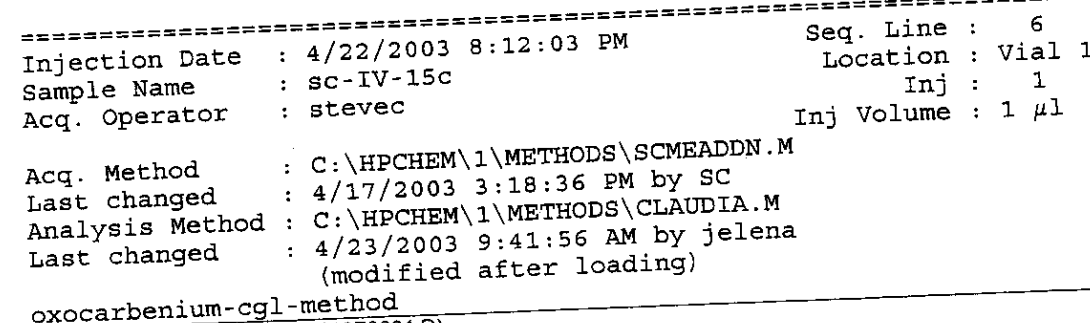

oxocarbenium-cgl-method

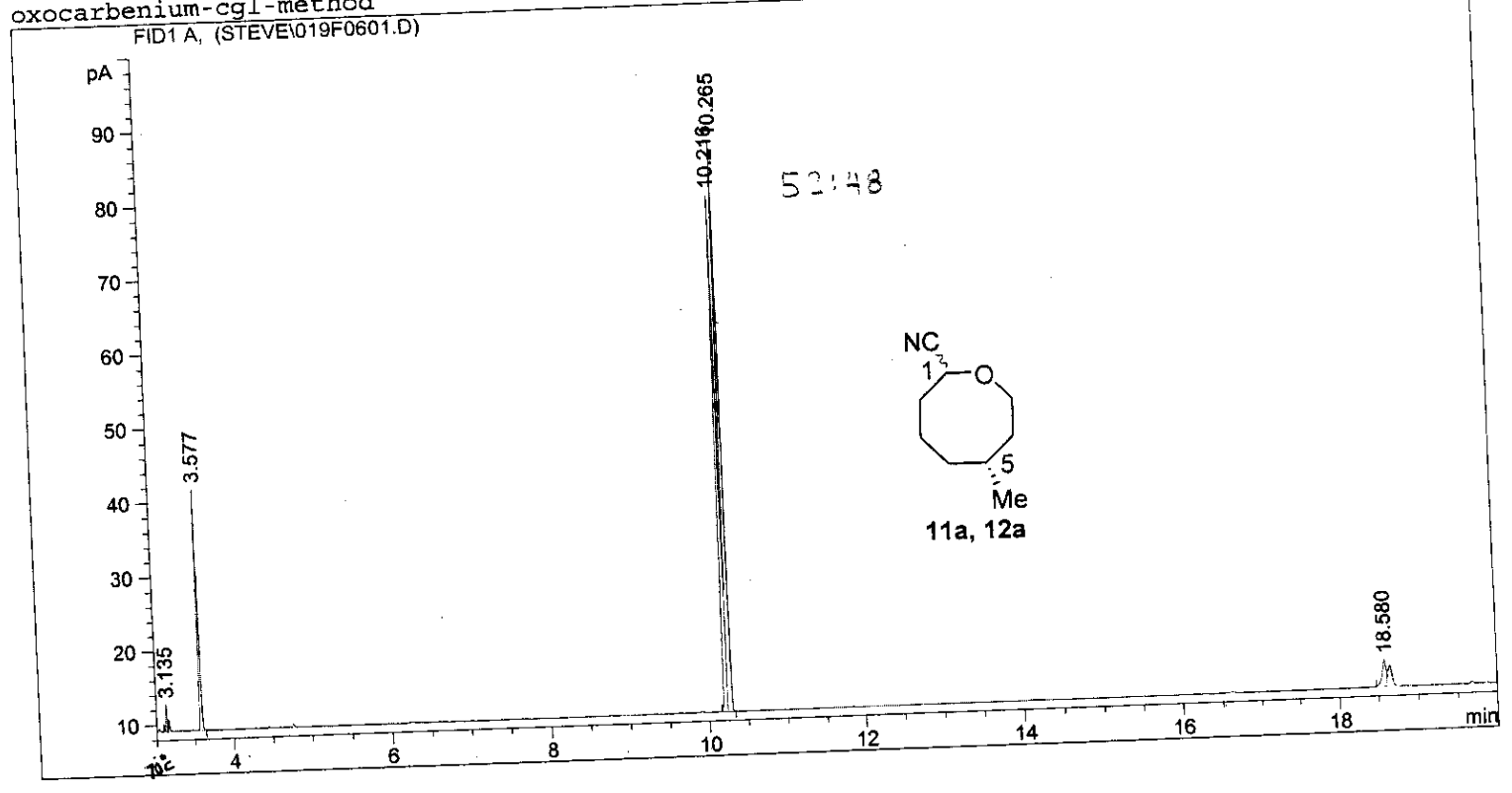

Area Percent Report

\begin{tabular}{|c|c|}
\hline sorted By & $:$ \\
\hline Multiplier & : \\
\hline
\end{tabular}

Signal 1: FID1 A,

\begin{tabular}{|c|c|c|c|c|c|c|c|}
\hline Peak & RetTime & Type & $\begin{array}{l}\text { width } \\
\text { [min] }\end{array}$ & $\begin{array}{r}\text { Area } \\
{[p A * s]}\end{array}$ & $\begin{array}{l}\text { Height } \\
\text { [pA] }\end{array}$ & $\begin{array}{c}\text { Area } \\
\text { q }\end{array}$ & \\
\hline \# & {$[\min ]$} & & {$[\min ]$} & L & ----- & -------1 & \\
\hline 1 & 3.135 & $\mathrm{BV}$ & 0.0174 & 4.21500 & 3.72938 & & \\
\hline 2 & 3.577 & PB & 0.0185 & 39.27439 & 32.64857 & $\begin{array}{l}12.27280 \\
39.29593\end{array}$ & $48^{310}$ \\
\hline 3 & 10.216 & VV & 0.0275 & 125.75155 & 69.72211 & $\frac{39.29593}{43.05726}$ & $50 \%$ \\
\hline 4 & 10.265 & VB & 0.0285 & 137.78824 & 76.72844 & $\frac{43.05726}{4.05687}$ & \\
\hline 5 & 18.580 & $\mathrm{BV}$ & 0.0466 & 12.98245 & 3.70723 & 4.05687 & \\
\hline & & & & 320.01162 & 186.53573 & & \\
\hline
\end{tabular}

Results obtained with enhanced integrator!

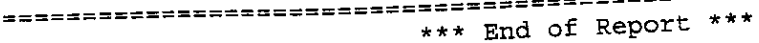

Page 1 of 1 

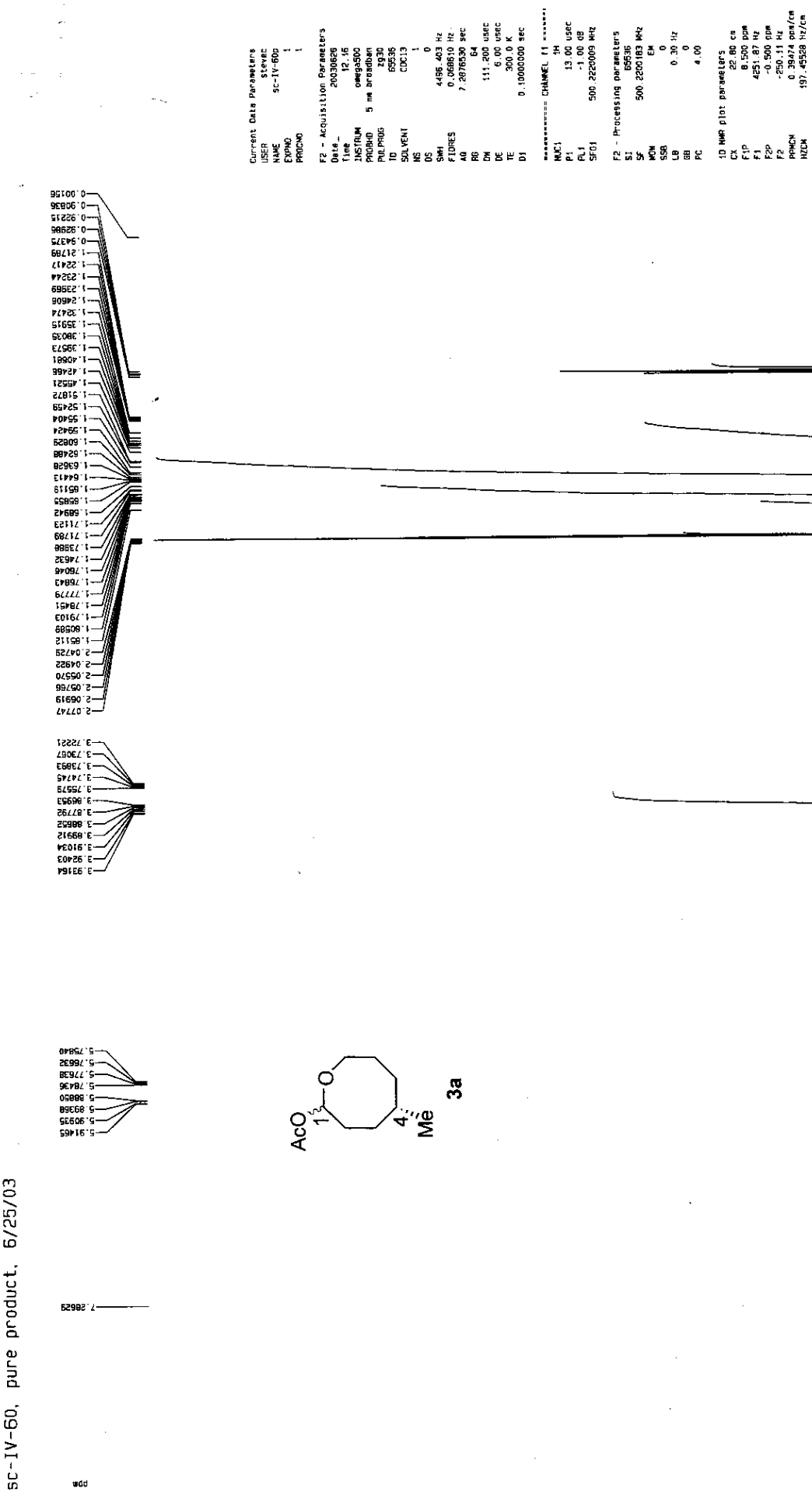


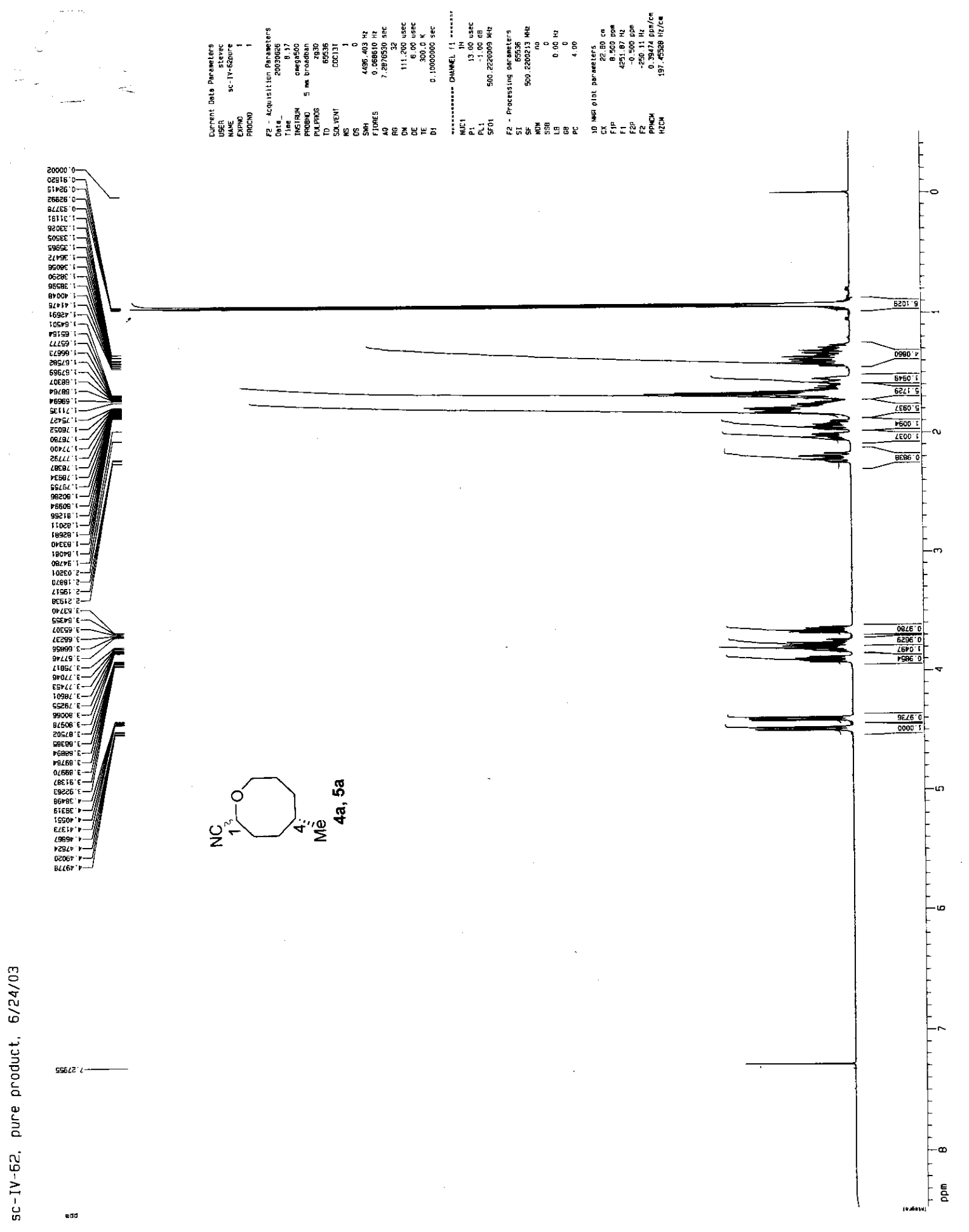



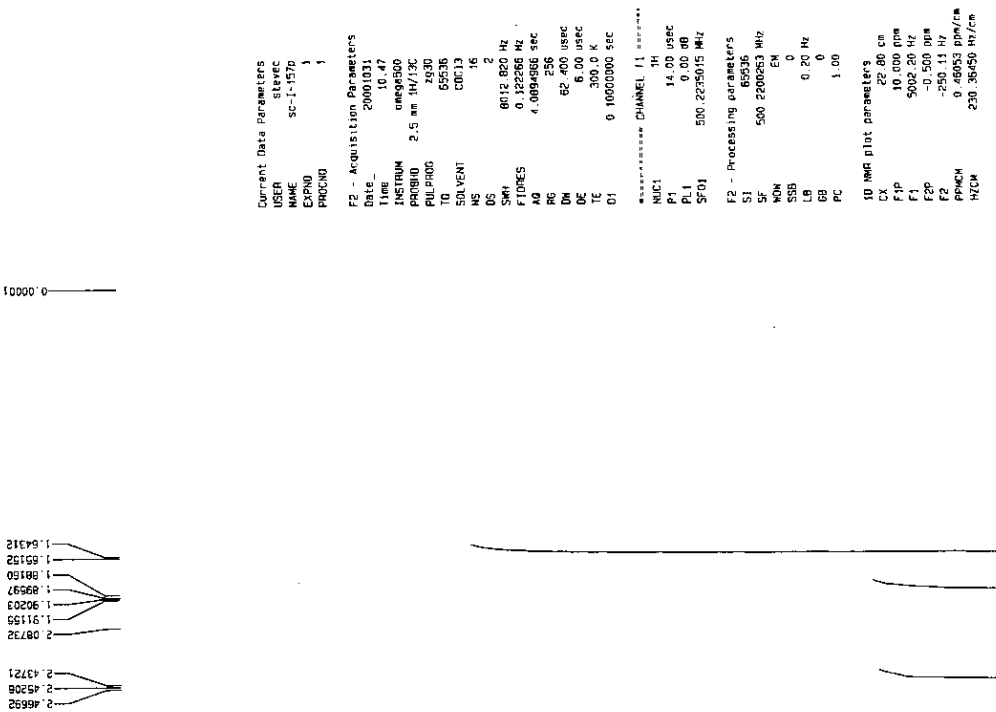

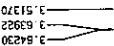
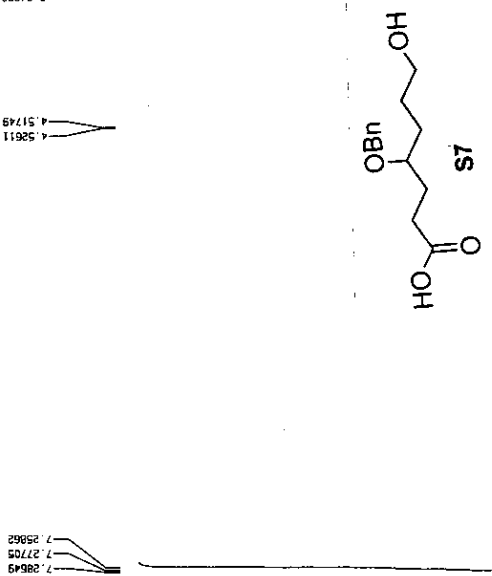

cc5z: $:$

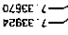

ஓ

落

亮

in

垈 

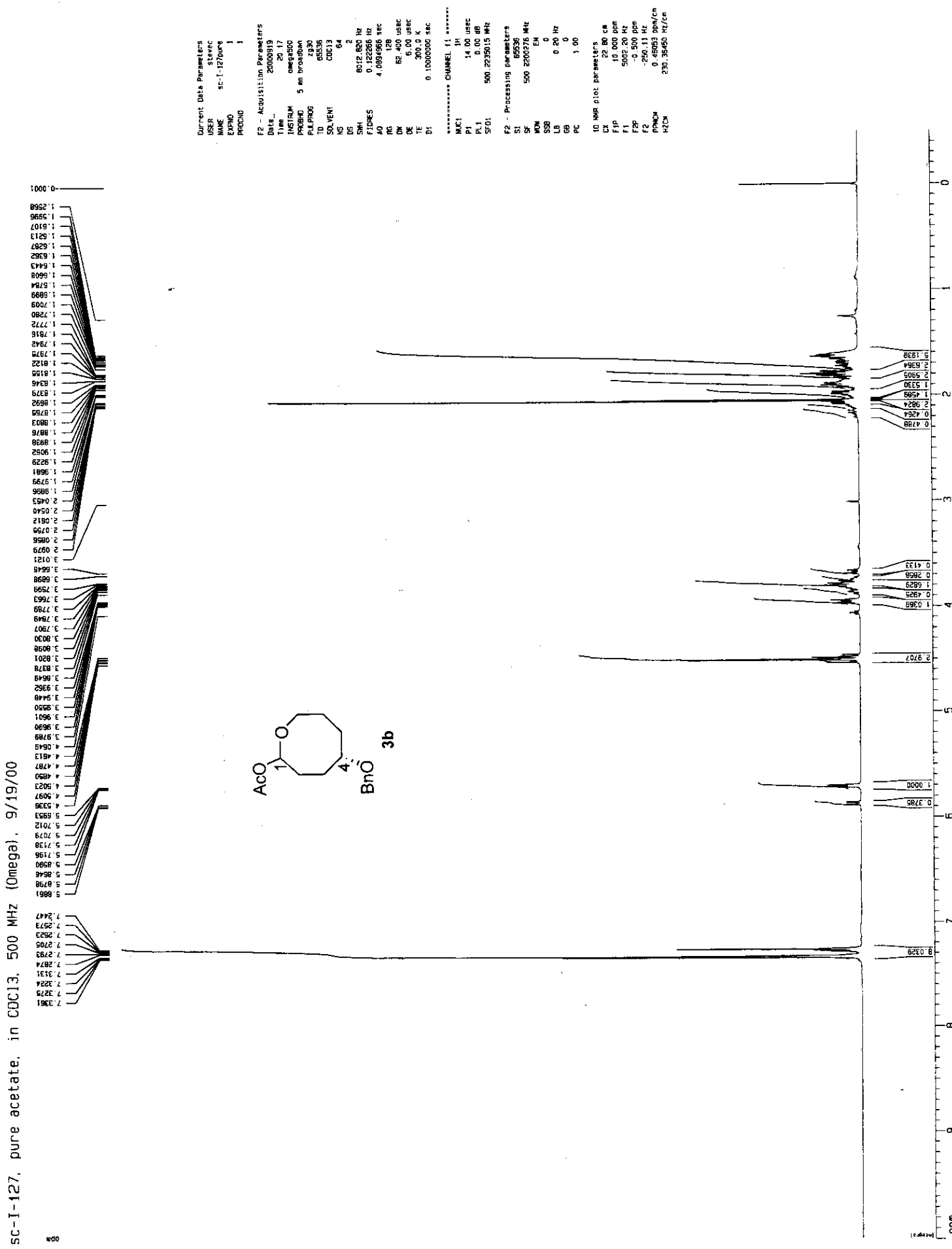

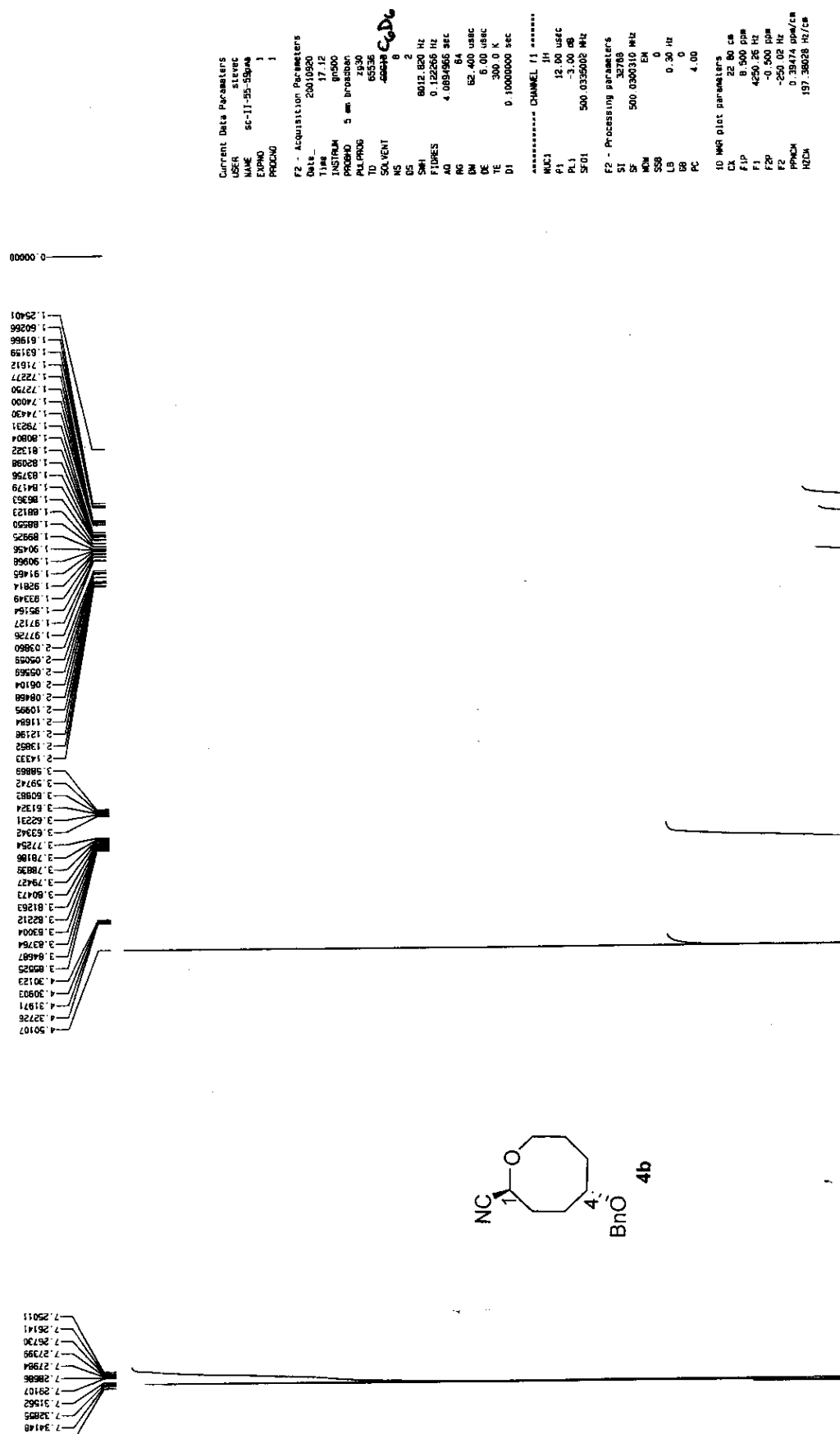


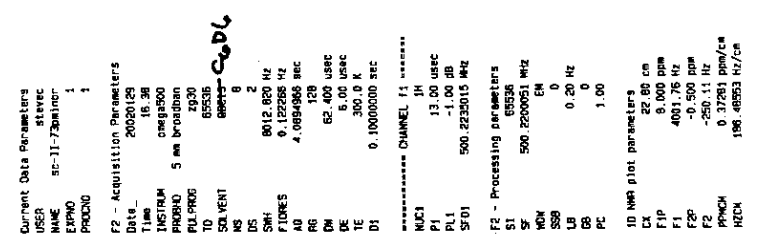

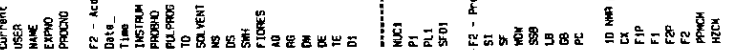
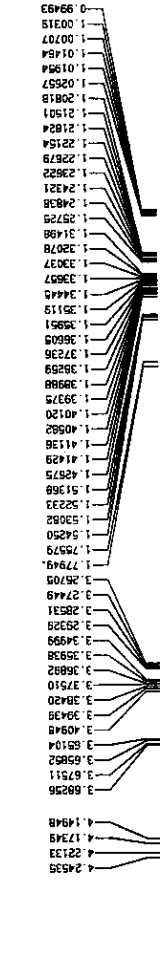

$\stackrel{5}{\square}$

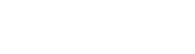

总

$$
\text { to }
$$

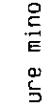
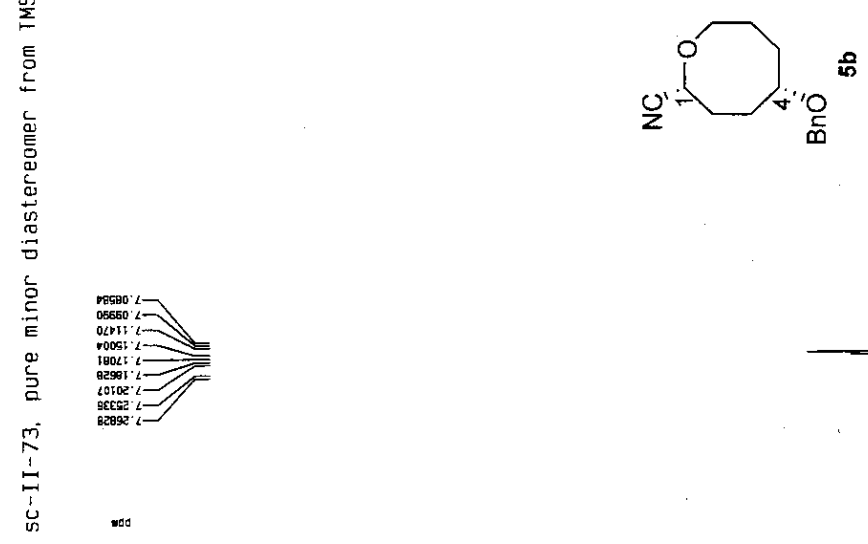

ติ 


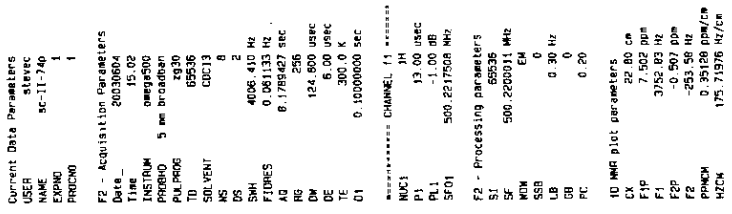

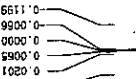

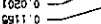

ז560';

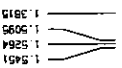

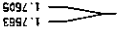

66512

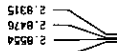

$458 e^{2}$

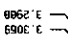

scez:

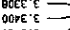

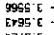

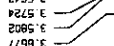

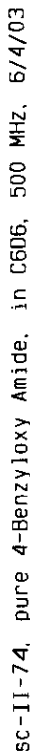

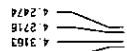

घ960:

$\operatorname{seg}^{2} \cdot 5$

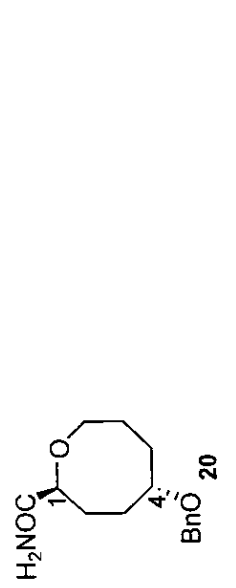

$626: 5$
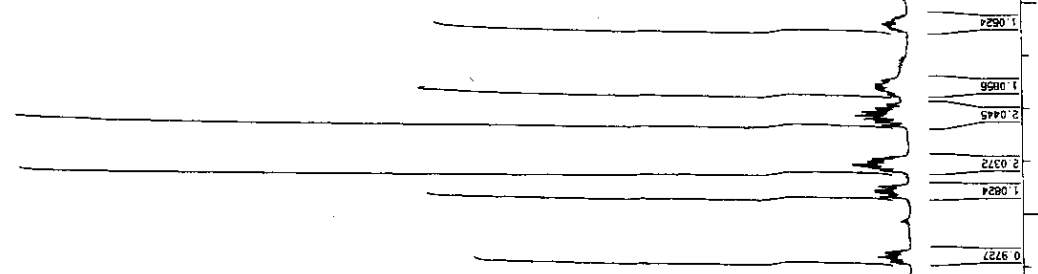

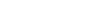

(

.

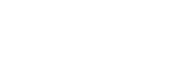

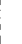

$\operatorname{sog}_{00} 6$

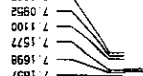

年

artid

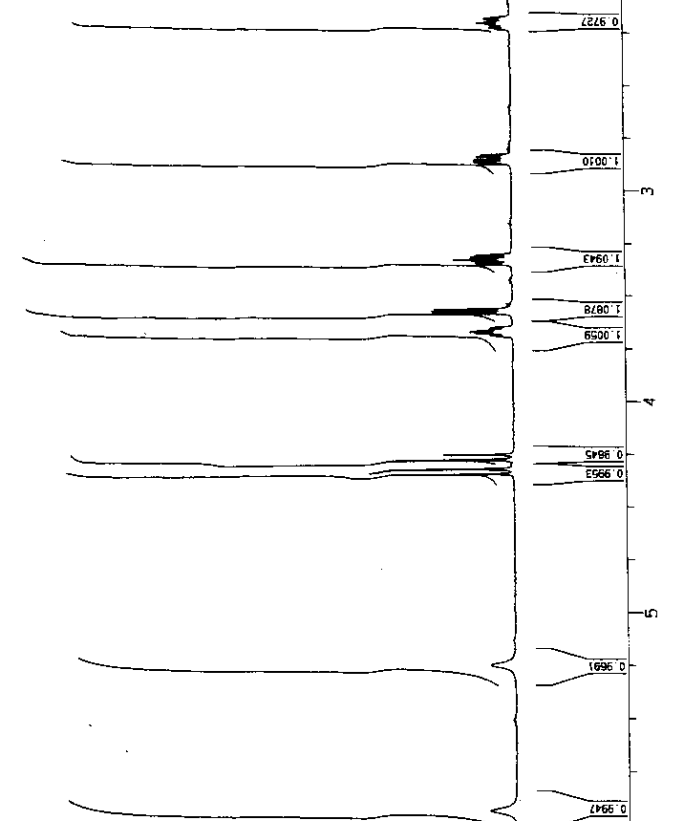



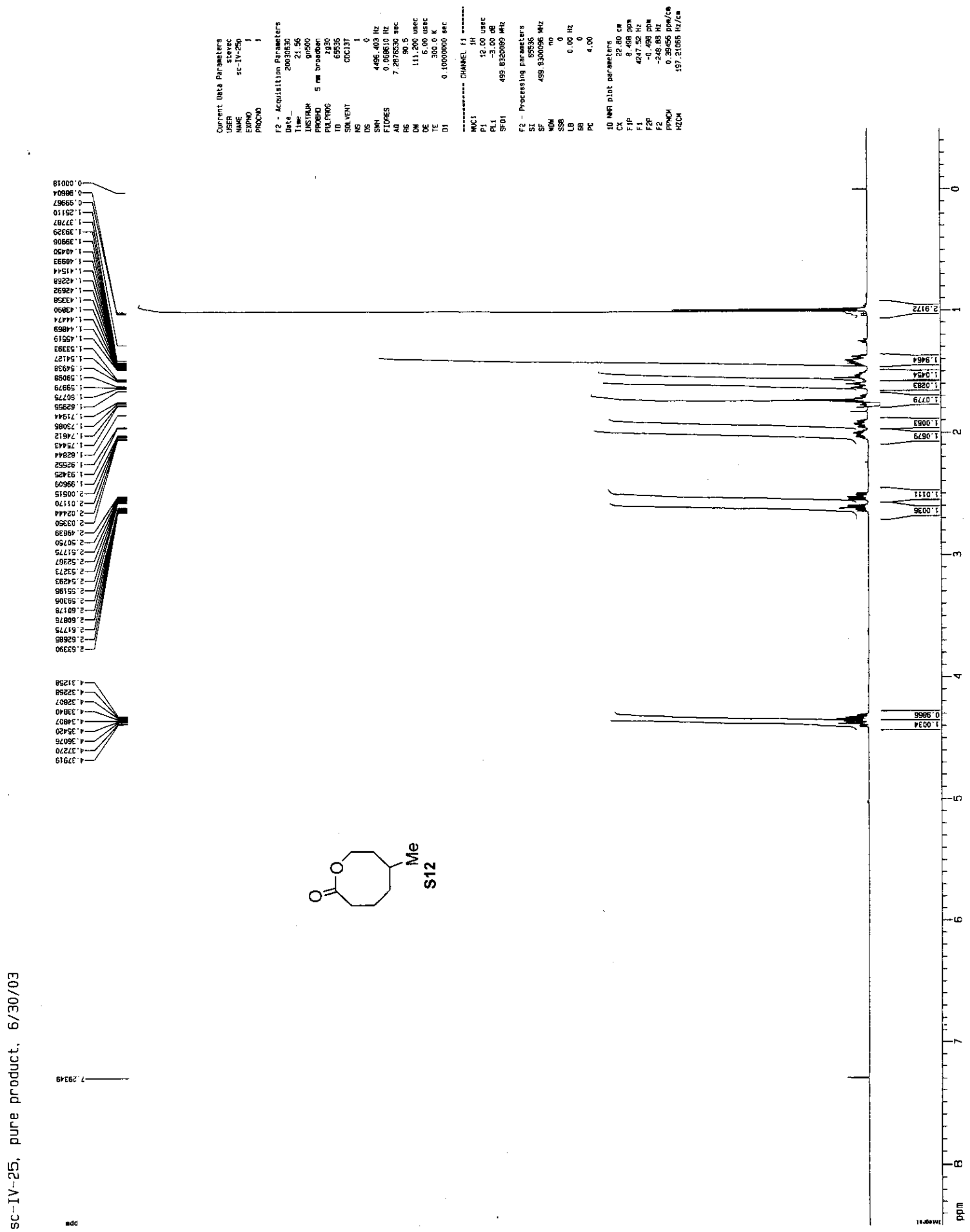


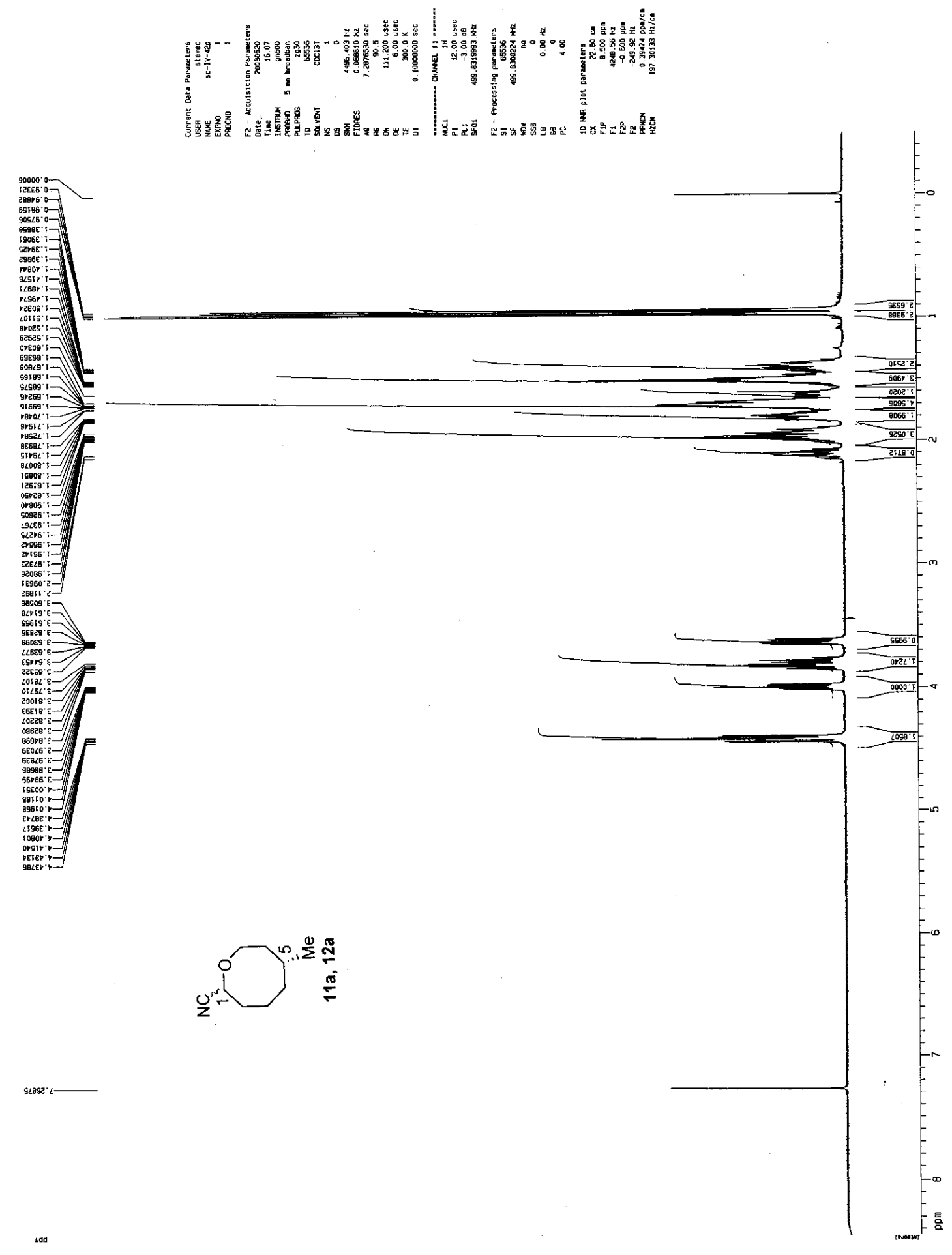




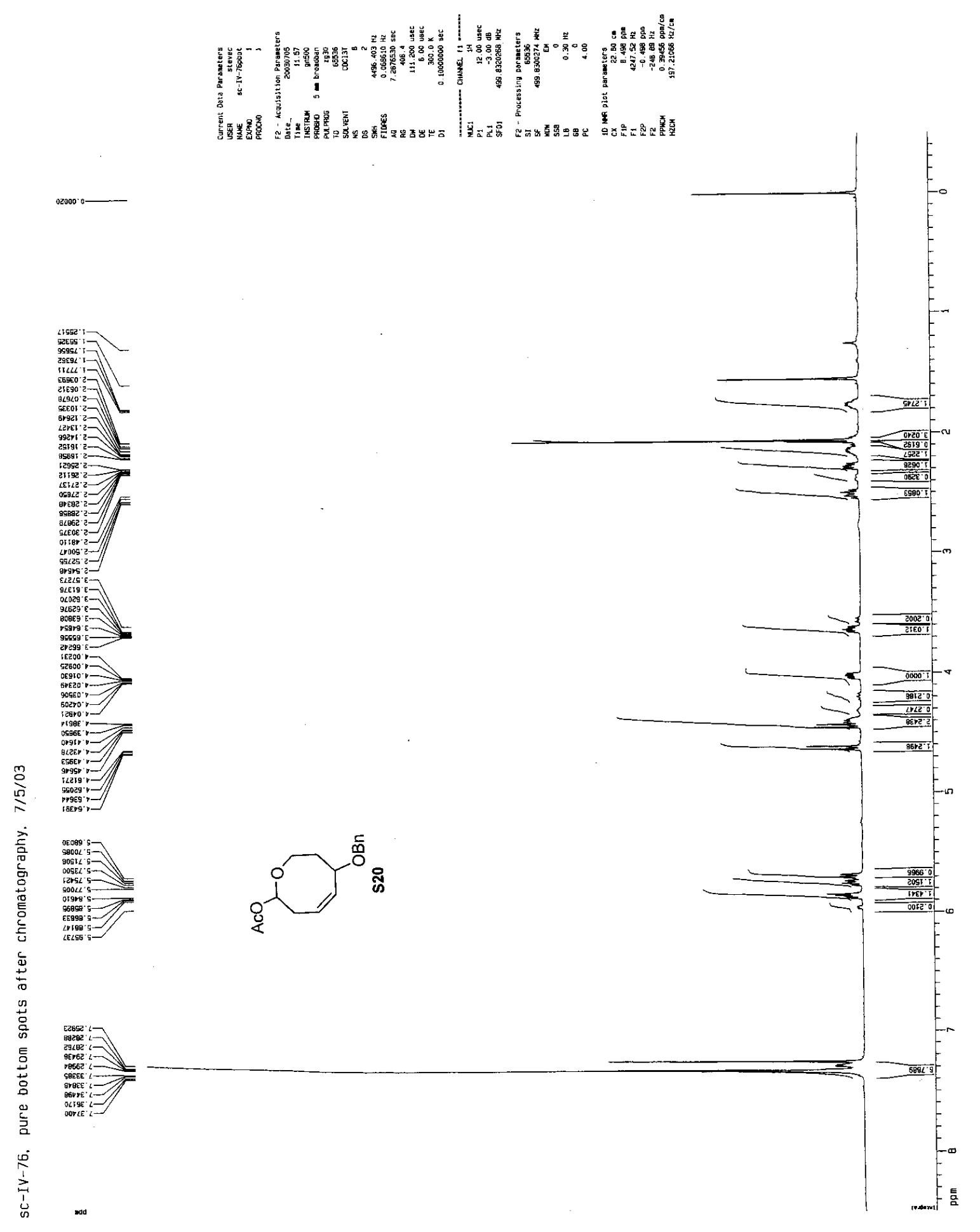




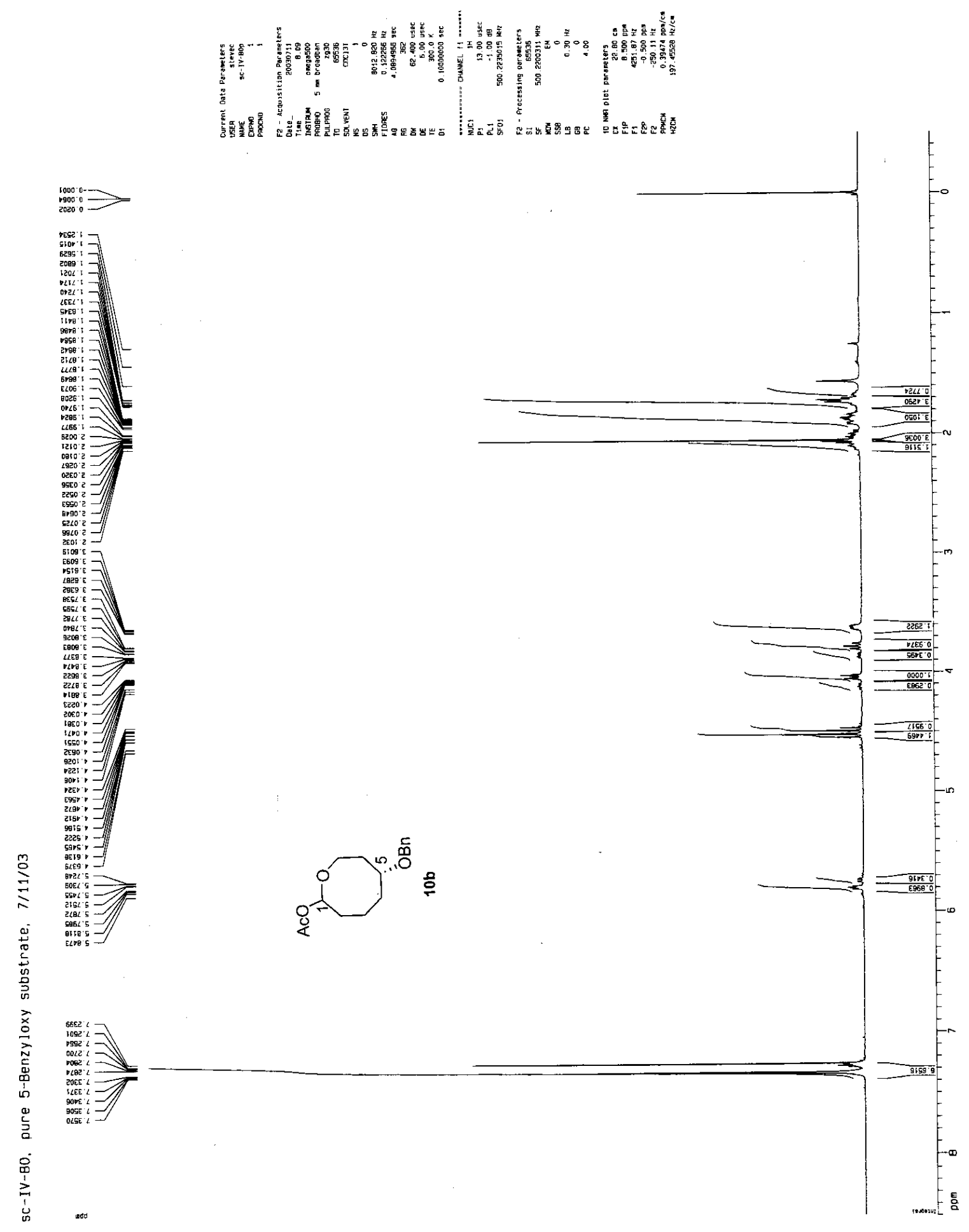



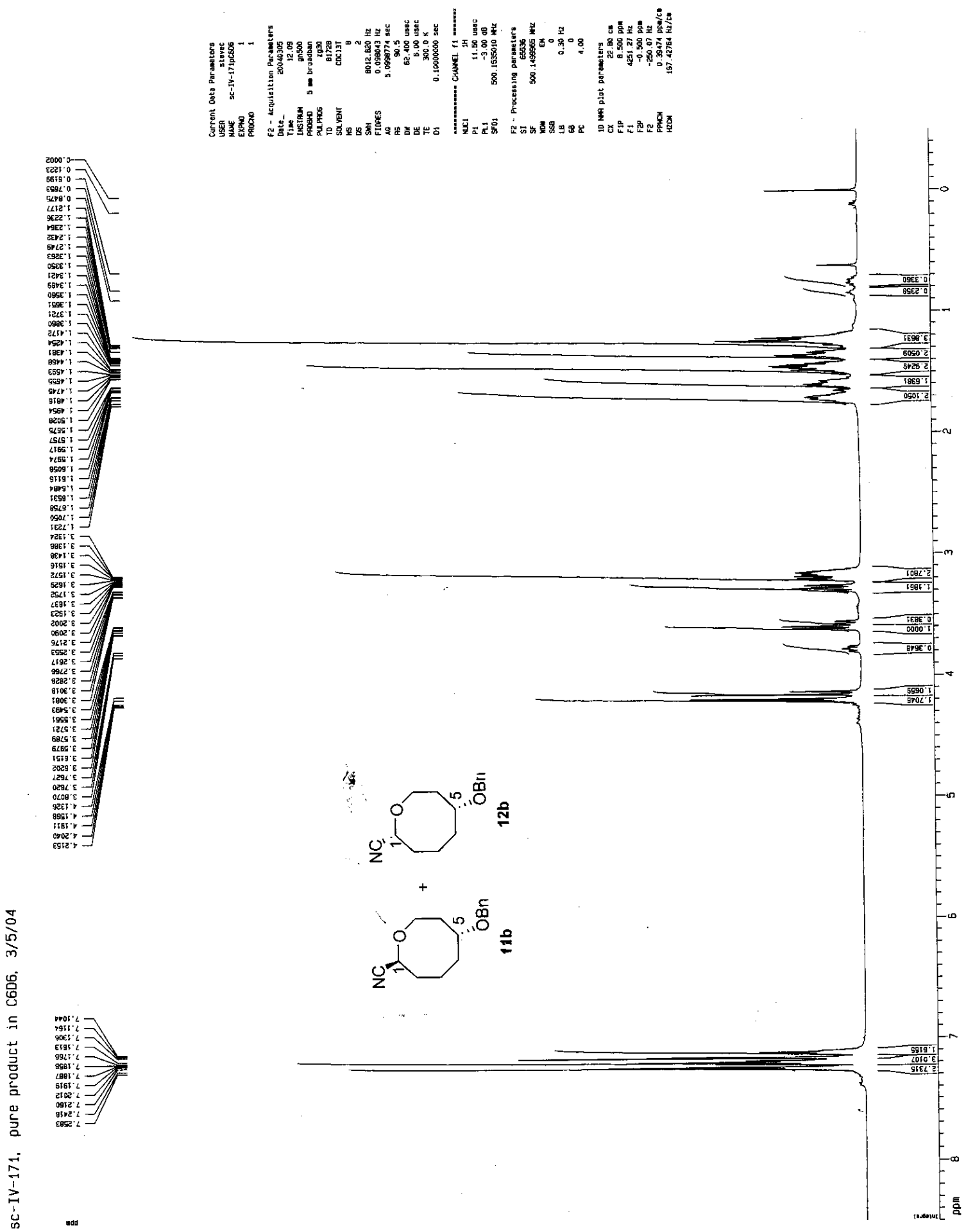


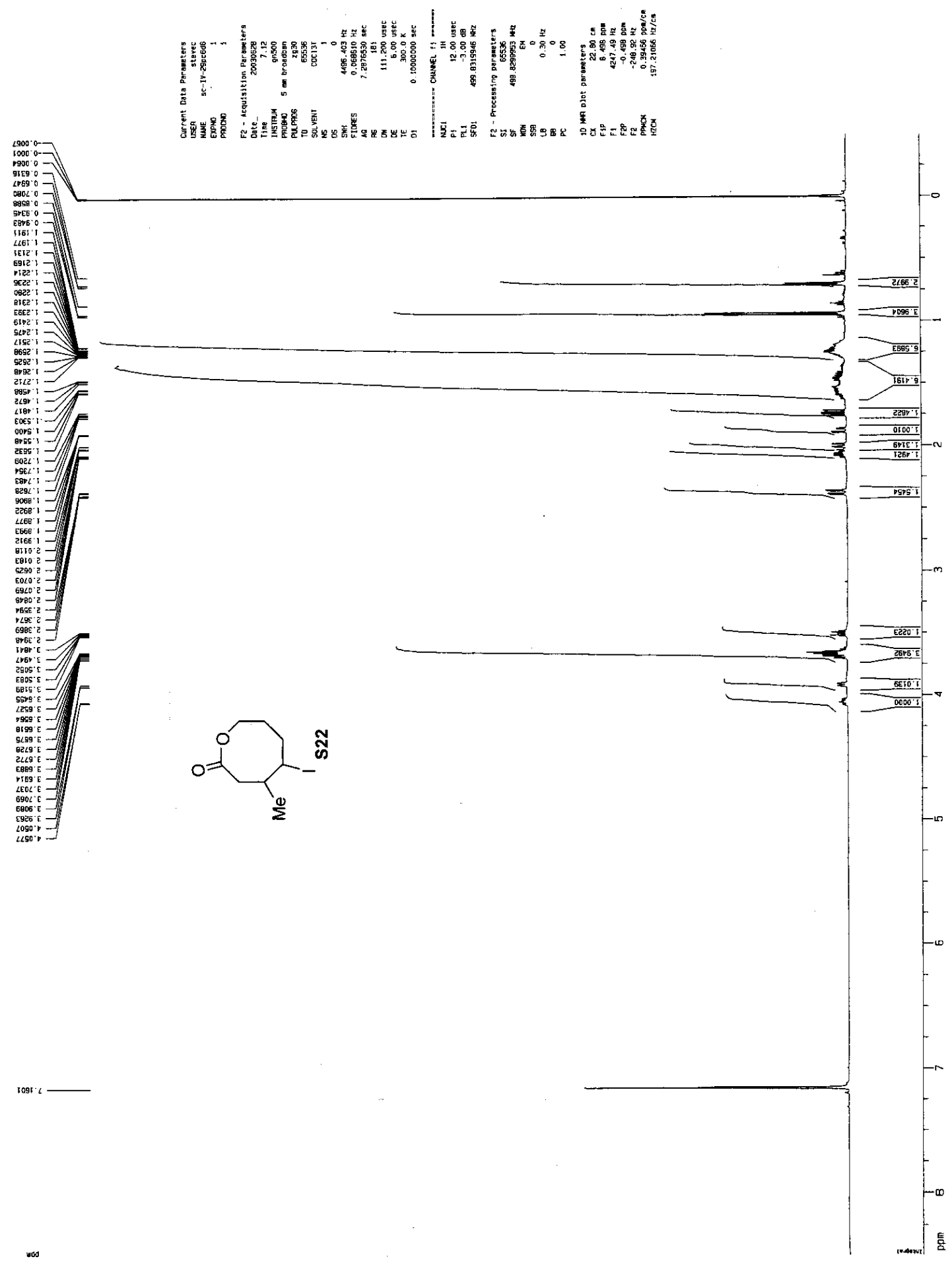



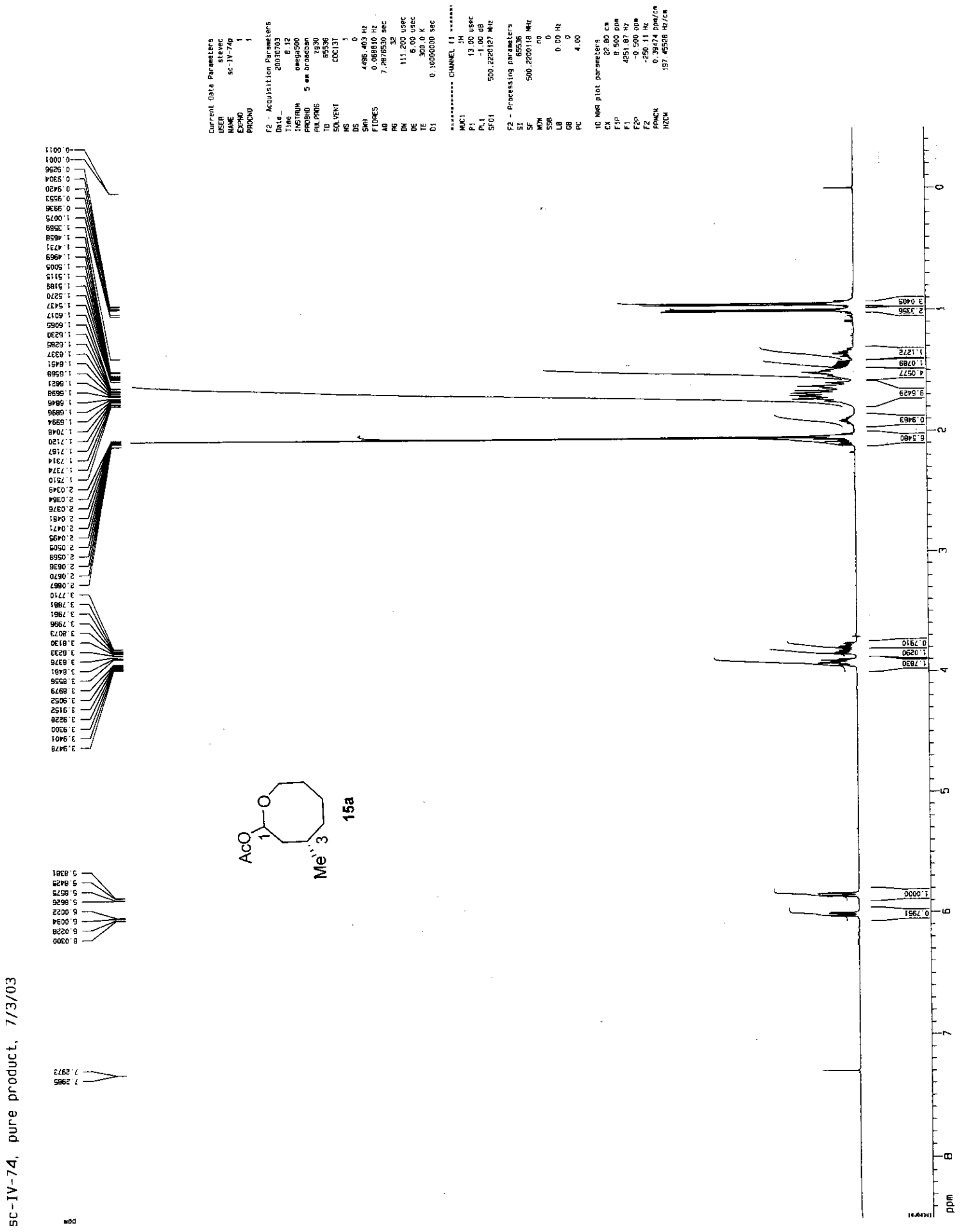

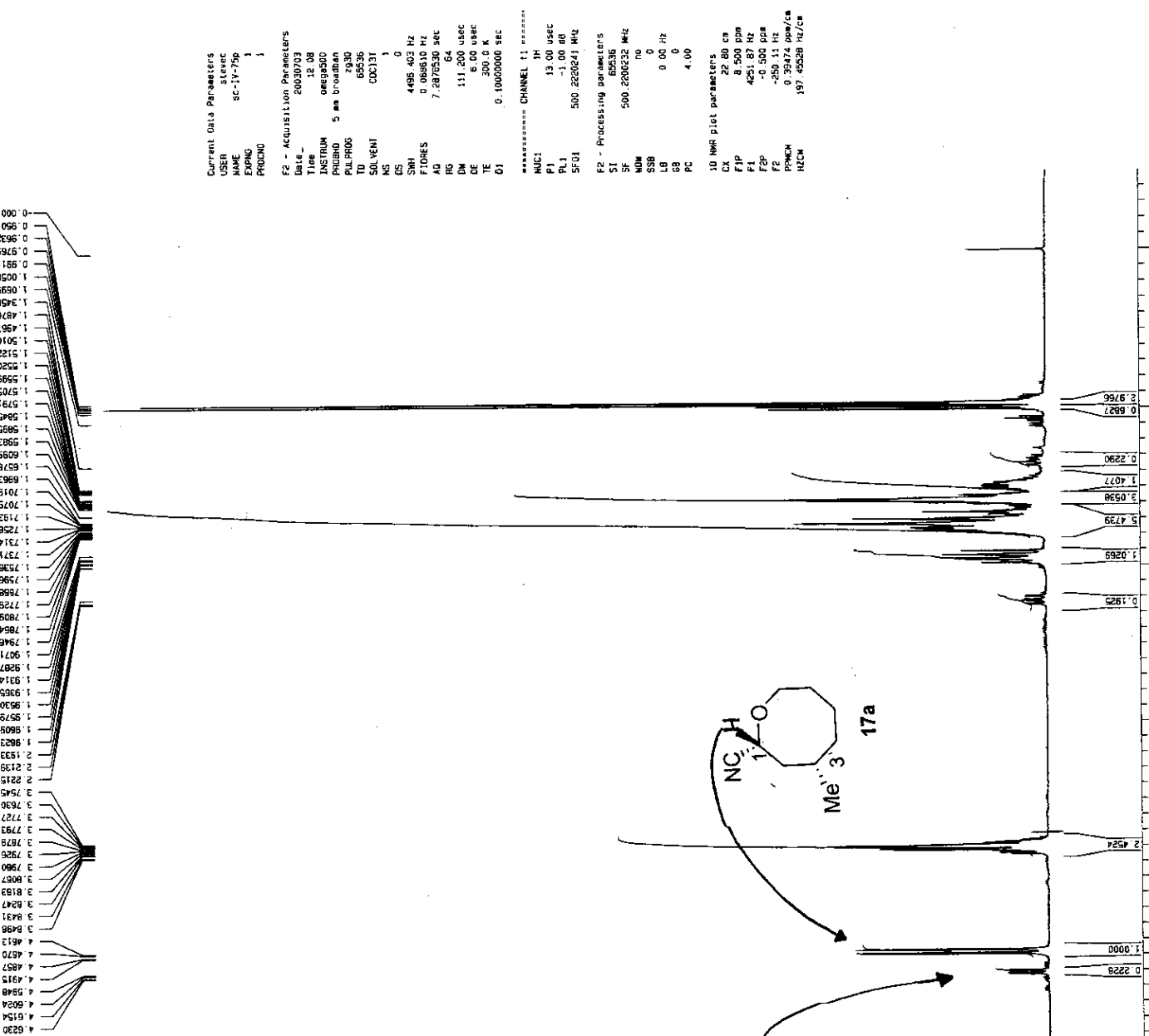

oeg?"

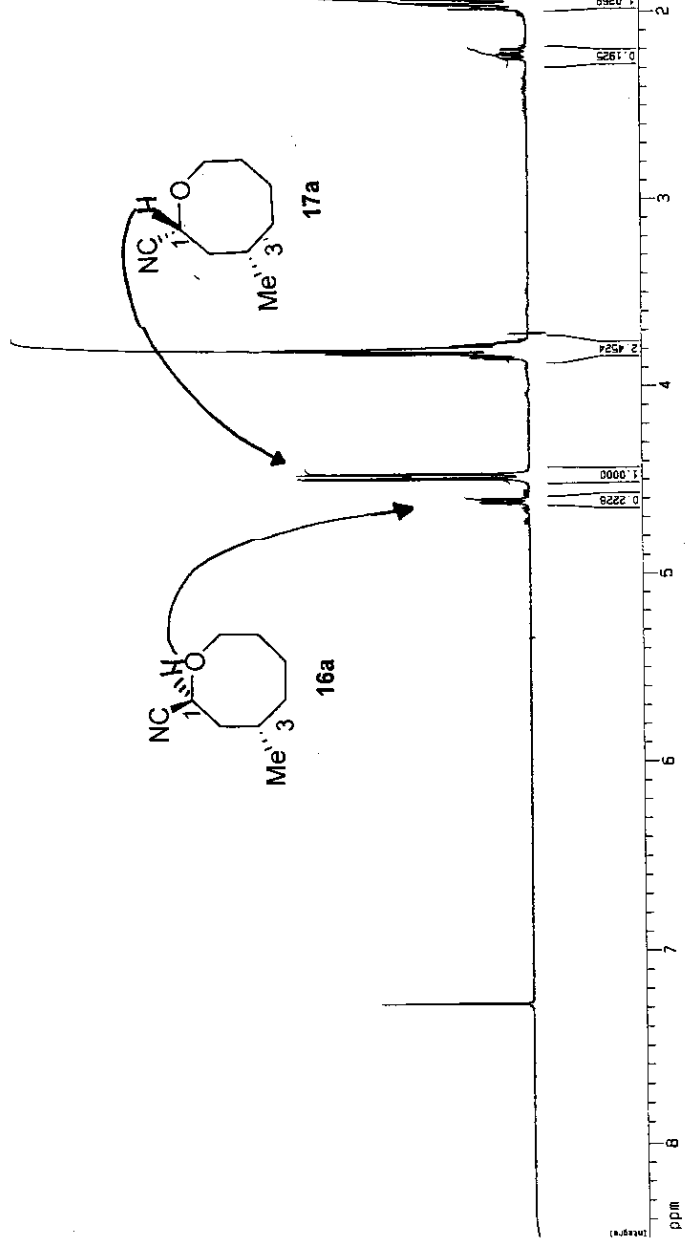




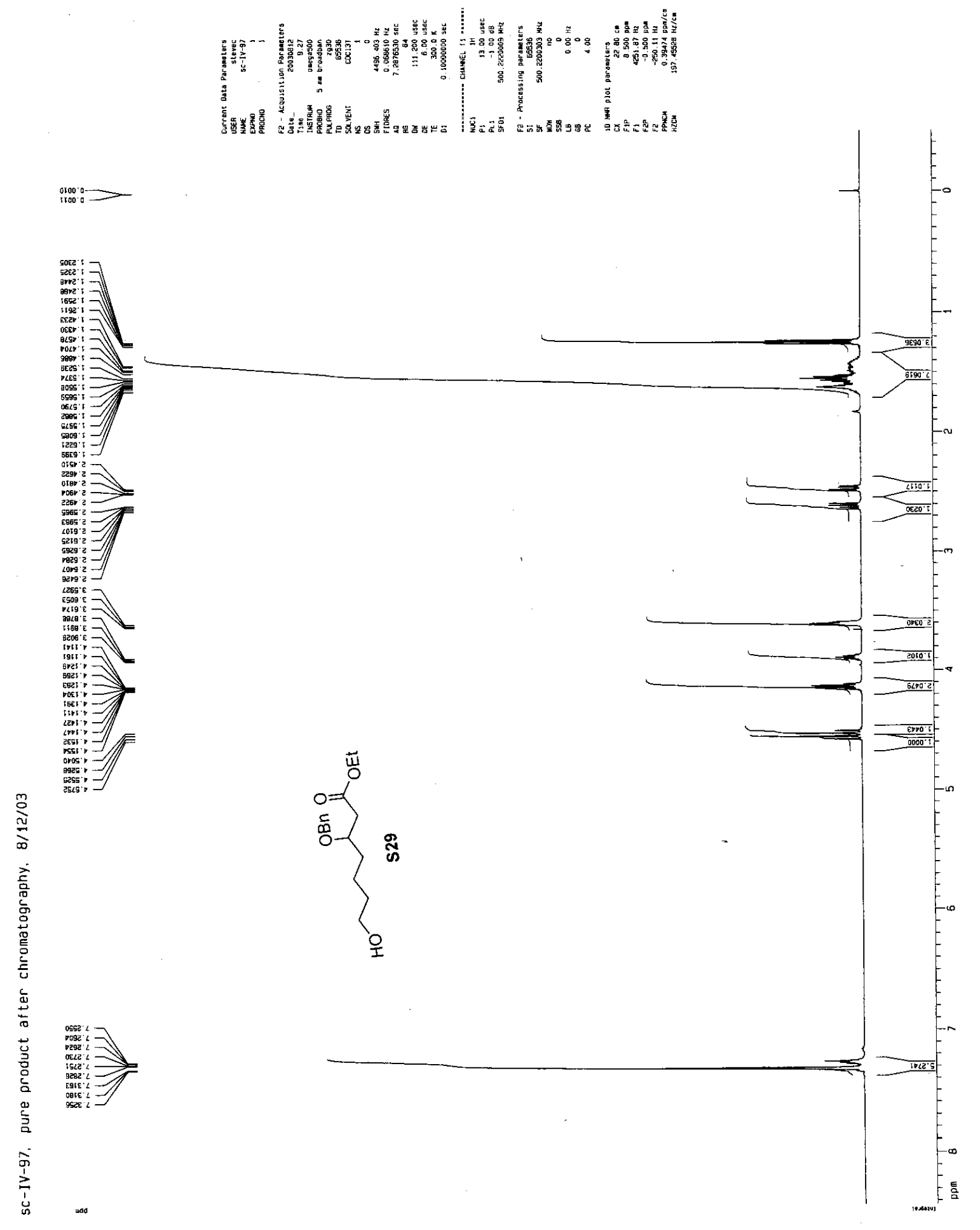



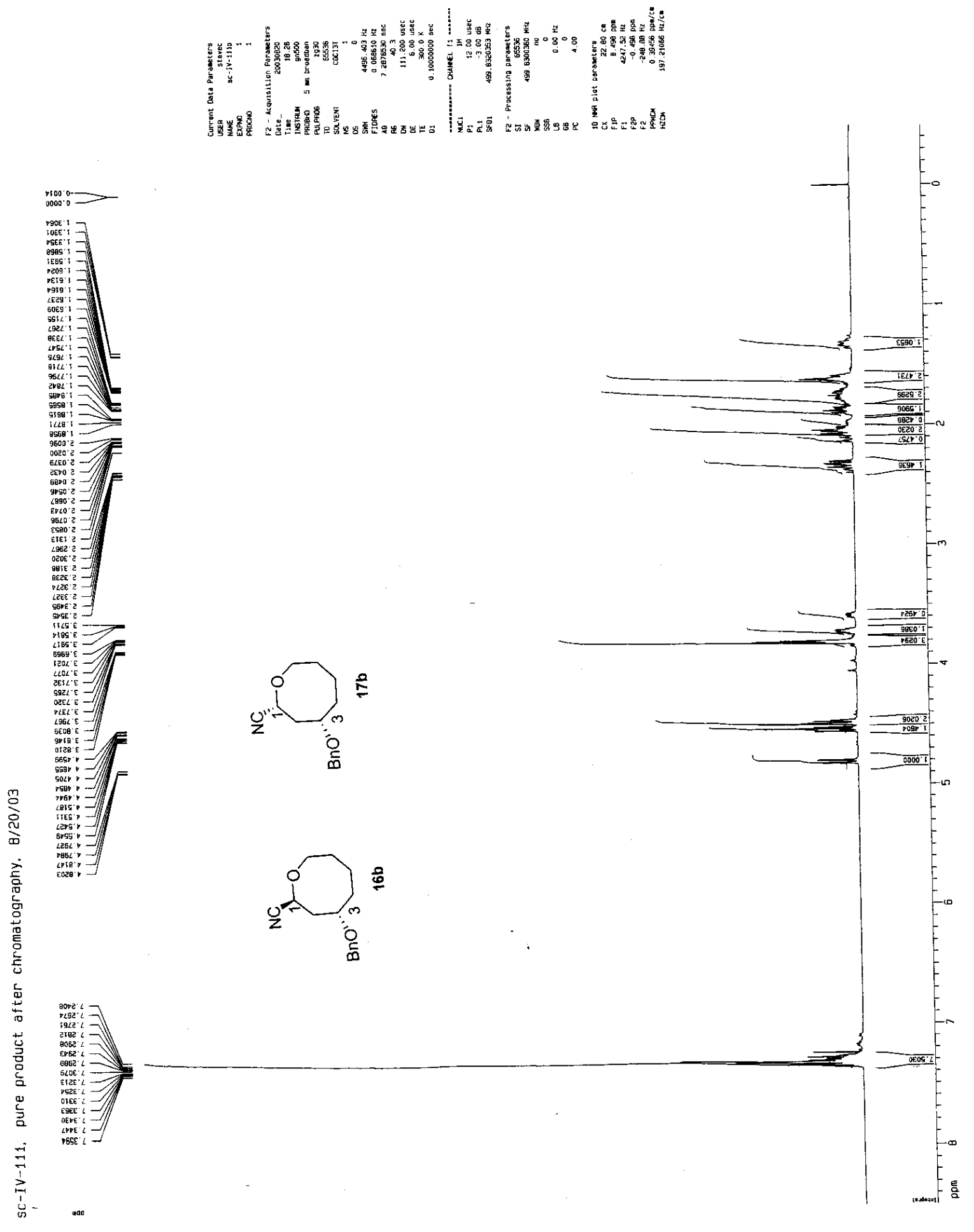